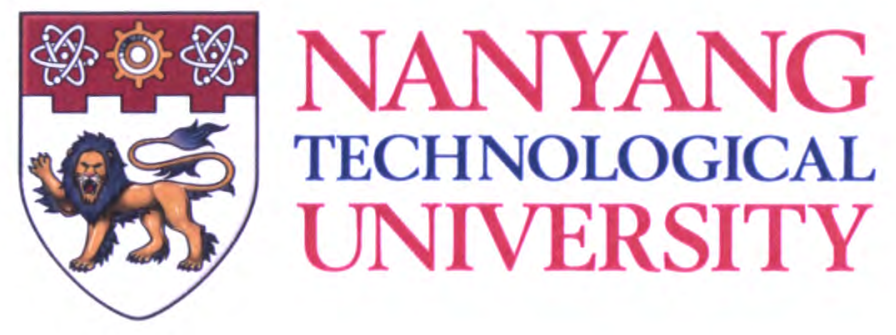

Geomorphic and sedimentologic imprints

of typhoons Durian and Haiyan storm surges

on the Philippine coasts

Janneli Lea A. Soria

Asian School of the Environment 


\section{Acknowledgements}

I am forever grateful to the Almighty God whose divine providence and grace allowed me to accomplish this work.

I thank Dr. Adam Switzer, my adviser, for the privilege to work on a project that is relevant to my country. He has been patient and very supportive throughout the study, providing me with good collaborative network amongst various scientific disciplines. I also thank Dr. Fernando Siringan, my thesis committee member, for being a constant source of insightful ideas to explore. Together, they have helped me formulate the ideas and identify the appropriate methodologies of this study. They nurtured me in a research environment with a right strike of balance between collaboration and independence.

I thank my thesis examiners Dr. Emma Hill, Dr. Brian Jones, and Dr. Robert Weiss for their thorough reviews and insightful comments that helped me polish this thesis to its final form.

The National Research Foundation Singapore under its Singapore NRF Fellowship scheme (National Research Fellow Award NRF-RF2010-04) awarded to Adam Switzer provided financial support. The Earth Observatory of Singapore (EOS) for granted me EOS Research Scholarship, which paved the way for my post-graduate education. The EOS and the Asian School of the Environment (ASE) have been a great place to study and a pillar of support through its research, technical, and administrative staff. I am grateful to Christina Tee, Clair Elaine Jerusha Devan, Sue-Ann Ong, May Pea, Chun Yu Wong, Debbie Permatasari, Sue Ping Lim, and Yvonne Soon for their patient assistance in all administrative work and for being 
always cheerful and excellent in the things that they do. Yves taught me basic Illustrator tools, which are helpful in creating good figures. Sorbi has been my GPS and surveying mentor, who ensures I got good quality elevation data.

I appreciate my group mates in the Coastal Lab: Fengling, Chris, Yingsin, Dat, Yen, Wenshu, Stephen, Constance, Linlin, Aaron, and Jeremy for their support in the different stages of my PhD. Their constructive criticisms have helped me improve my presentations for the qualifying exam and international conferences, and also my manuscripts. Special thanks to my friends Constance, Louisa, Jani, Lujia, Linlin, Riovie, Wenshu, Stephen, Yen, Guangxing, Xinhui, Sebastian, Eliz, Ross, Taufiq, River, Yudha, Gisella, and Wen-Chien for filling my stomach with good food and my heart with joy. To Dat, QQ, and Liqing, I am honored to journey with you throughout our $\mathrm{PhD}$ studies.

I extend my thanks to Every Nation Church Singapore Jurong through NTU and Ladies' lifegroup for their friendship and prayers. I am blessed with the Oblefias, Ocampo, and Velasco families, who adopted me and loved me as though I am part of their households. I thank Marvz for ensuring that I don't lose my data files, keeping them accessibly secured.

My friends and previous colleagues in the Philippines provided tremendous assistance for all the intensive fieldworks. The Marine Science Institute (MSI) through the Geological Oceanography and Physical Oceanography groups extended logistic support in the field and allowed the use of its facilities whenever I have trips to the Philippines. Mommy Yvaine, Zoan, Ron, Meekay, Dondon, Angel, Nicnic, Erwin, Jess, and Gia have been my dependable field assistants, and are always ready to go the extra mile in processing local permits, compiling other 
primary data, packing, storing, and sending my samples to Singapore. Boss K, Ate Olive, Princess, and Ian helped me understand better storm surge dynamics through their computer simulations. I am blessed with friends like Yo, Lester, Arlene, Zoan, and Elton who would not only enjoy conducting fieldwork but also ensure that everything is thoroughly and excellently documented on still photos. Caloy and Mahar were very generous in allowing me to use their GPS equipment. I also appreciate the Philippine Institute of Volcanology and Seismology through Art and Mabee for giving us the opportunity to use their GPR equipment. Mark Lapus sent us with relief goods and the University of the Philippines Tacloban provided us shelter during our initial trip to Tacloban, two weeks after the Haiyan disaster. Special thanks to the Cabria family and de Lira family for warmly welcoming us in their homes and providing us comfort at the end of the tiring days spent on the field.

To Hermann, Jessica, and Nicole thank you for flying over to the Philippines two months after Typhoon Haiyan and generously imparting your knowledge and expertise on storm surges and storm deposits.

To my family- Papa, Mama, Jajo, Jason, Shane, and Quin, thank you so much for the unconditional love, and for always being there with me to share the joys of my triumphs and failures.

Finally, I honor the people of Albay (Malinao, Tabaco, and Sto. Domingo), Leyte (Dulag, Tolosa, Tanauan, and Tacloban), and Samar (Basey, Hernani, and Llorente) for their kindness and hospitality. Know that your resilience have thought me how to appreciate life and to rise above amidst adversity. To you I dedicate this work. 


\section{NANYANG TECHNOLOGICAL UNIVERSITY ASIAN SCHOOL OF THE ENVIRONMENT Statement of Co-Authorship}

The following people and institutions contributed to the publication of work undertaken as part of this thesis:

\section{Paper 1, Repeat Storm Surge Disasters of Typhoon Haiyan and Its 1897 Predecessor in the Philippines \\ Published in Bulletin of the American Meteorological Society \\ Located in Chapter 2}

Lea was the primary author, and with Adam, and Fernando conceptualized the idea, its formality and development. Lea, Cesar, Olive, Yvaine conducted the initial field survey two weeks after Typhoon Haiyan's landfall measuring flow depths and interviewing eyewitnesses. Riovie compiled new clippings and relevant video recordings on Haiyan. Cesar, Princess, Olivia, and Ian conducted the storm surge modelling. Hermann lead the high-water marks survey and analysed the data. Lea compiled and synthesized all data, and led the writing up of the paper with contributions from Adam, Cesar, Hermann, Olivia, Fernando, and Yvainne.

Janneli Lea A. Soria: $50 \%$

Adam D. Switzer: $10 \%$

Cesar L. Villanoy: $9 \%$

Hermann M. Fritz: $8 \%$

Princess Hope T. Bilgera: 5\%

Olivia C. Cabrera: $5 \%$

Fernando P. Siringan: 5\%

Yvainne Yacat-Sta. Maria: 5\%

Riovie D. Ramos: $2 \%$

Ian Quino Fernandez: 1\%

We the undersigned agree with the above stated "proportion of work undertaken" for each of the above published peer-reviewed manuscript contributing to this thesis:

Signed:

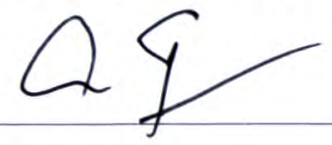

Date: 17 NovenBer 204

Adam Switzer

Supervisor

Asian School of the Environment

Nanyang Technological University

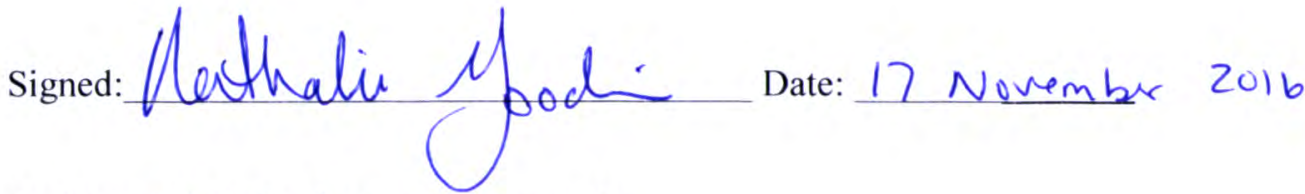

Assistant Chair Graduates and Research

Asian School of the Environment

Nanyang Technological University

ASIAN SCHOOL OF THE ENVIRONMENT 


\section{Table of Contents}

Chapter 1 Introduction 1

1.1. What is a storm surge?

1.2. What is overwash?

1.3. Geomorphic imprints of storm overwash 6

1.4. Sedimentologic imprints of storm overwash 8

$\begin{array}{ll}\text { 1.5. Carbonate coastlines } & 10\end{array}$

1.6. Storm surges in the Philippines 11

1.6.1. What do we know? 11

1.6.2. What do we not know? 13

1.7. Thesis structure 16

$\begin{array}{ll}\text { References } & 18\end{array}$

Chapter 2 Repeat storm surge disasters of Typhoon 24

Haiyan and its 1897 predecessor in the Philippines

Abstract 25

2.1. Introduction $\quad 26$

2.2. Typhoon Haiyan $\quad 27$

2.3. Material and Methods $\quad 29$

$\begin{array}{ll}\text { 2.3.1. Field Survey } & 29\end{array}$

2.3.2. Storm Surge Modeling of Typhoon Haiyan $\quad 34$

2.3.3. Storm surge modeling of Ty $1897 \quad 36$

2.4. Typhoon 1897 versus Typhoon Haiyan 37

2.4.1. Typhoon track and forward speed 37

2.4.2. Typhoon intensity and size 41

2.5. Typhoon 1897 and Typhoon Haiyan storm surges 43

2.5.1. Post-typhoon field measurements 43

2.5.2. Storm surge simulations of Typhoon Haiyan and Ty 46

1897 in San Pedro Bay

2.6. Implications for disaster management 51

2.6.1. Understanding the local storm surge hazard 51

2.6.2. Multi-hazard evacuation strategies 54

2.6.3. Typhoon warning and response $\quad 56$

2.7. Conclusion $\quad 58$

Acknowledgements $\quad 59$

$\begin{array}{ll}\text { References } & 60\end{array}$ 
Chapter 3 Sedimentary record of Typhoon Haiyan 66 from Leyte Gulf coastlines shows a hybrid signature

Contributions

Abstract

3.1. Introduction

3.2. Typhoon Haiyan 71

3.3. Study Area $\quad 72$

3.4. Methods 74

3.5. Results 79

3.5.1. Beach erosion and post-storm beach recovery $\quad 79$

3.5.2. Haiyan overwash sediments in Tanauan 81

3.5.3. Haiyan overwash sediments in Basey 87

3.6. Discussion 90

3.6.1. Haiyan overwash sediments have clear contrasting $\quad 90$

sedimentology near the shore but show similar

sedimentology inland

3.6.2. Haiyan overwash sediments came from multiple $\quad 92$

sources

3.6.3. Sedimentary structures are consistent with a 93

turbulent, high-velocity storm surge flow

3.6.4. Haiyan overwash sediments exhibit similar 94

features with other extreme marine inundation deposits

3.7. Conclusion

99

Acknowledgements 101

References 101

Chapter 4 Typhoon Haiyan storm surge carried two distinct sediment assemblages on the carbonate coast 109 of Hernani, Samar, central Philippines

$\begin{array}{ll}\text { Contributions } & 110\end{array}$

Abstract 111

4.1. Introduction 112

4.2. Typhoon Haiyan and storm surge $\quad 115$

4.3. Study Area 116

4.4. Methods 117

4.4.1. Post-typhoon Haiyan survey 117

4.4.2. Reef flat boulders $\quad 120$

4.4.3. Onshore carbonate sediments 122

4.4.4. Application of the TsuSed model (TsuSedMod) 124

4.5. Results and Discussion $\quad 126$

4.5.1. Reef flat boulder deposition $\quad 126$

4.5.2. Onshore sediment deposition $\quad 130$

4.5.3. Across-shore flow velocity 135

4.6. Conclusion 136

Acknowledgements 137

$\begin{array}{ll}\text { References } & 138\end{array}$ 


\section{Chapter 5 Geomorphological and sedimentological}

records of recent storm history of the volcaniclastic coast in Lagonoy Gulf,central eastern Philippines

Contributions

Abstract

5.1. Introduction 147

5.2. Study Area 149

5.2.1. Typhoon Durian 149

5.2.2. Notable historical storms in Lagonoy Gulf and $\quad 149$ surrounds

5.2.3. Coastal geomorphology 152

5.3. Materials and Methods 152

5.3.1. Image interpretation and initial field investigation $\quad 152$

5.3.2. Ground penetrating radar (GPR) survey and $\quad 157$

chronological control

5.3.3. Luminescence dating 158

5.4. Results 159

5.4.1. 2006 Typhoon Durian landscape changes and post- 159

Durian modifications

5.4.2. Stratigraphy on the washover fan 161

5.4.3. Vertical and lateral textural trends of the washover 164 deposit

5.4.4. Sediment source of the Typhoon Durian washover 166 deposit

5.4.5. Ground penetrating radar profiles $\quad 166$

5.4.6. Chronological control 171

5.5. Discussion 173

5.5.1. Geomorphologic imprints of coastal inundation $\quad 173$ and their preservation

5.5.2. Storm surge history reconstructed from sediment $\quad 174$ record

5.6. Conclusions 175

Acknowledgement 176

References 177

Chapter 6 Synthesis 181

6.1. Key Results 182

6.2. Limitations 185

6.3. Future studies 186

References $\quad 187$

\section{Appendices}




\section{List of Figures}

\section{Chapter 1}

Figure 1.1. Diagram showing a tropical cyclone 2

Figure 1.2. Increasing level of marine inundation 2

Figure 1.3. Overwash process on a barrier-island or beach system 5

Figure 1.4. Plan view of landform elements in a dune system that
sustained overwash

Figure 1.5. Cross-shore profile of a generalized washover fan

stratigraphy

Figure 1.6. Schematic diagram showing high-energy wave action as one possible mode of formation for a reef-platform coral boulder Figure 1.7. Storm tracks (gray lines) of landfalling typhoons in the Philippines covering the period 1884 to 2014

Figure 1.8. Philippine map showing the tracks of the typhoons and the specific areas covered in each chapter.

\section{Chapter 2}

Figure 2.1. Storm tracks of three deadly typhoons crossing the central Philippines - Ty 1897, November 1991 TS Thelma, and November 2013 Super Typhoon Haiyan.

Figure 2.2. Maximum storm surge heights, surge with waves, and runup points of Typhoon Haiyan in eastern Leyte and Samar islands

Figure 2.3. Geographical coverage, bathymetry, and tidal conditions of Leyte Gulf

Figure 2.4. Sea-level heights in Tacloban and nearby coasts around San Pedro Bay during Typhoon Haiyan

Figure 2.5. Storm surge model sequence of Ty 1897 in San Pedro Bay

Figure 2.6. Modeled surge heights comparison between Ty 1897 and Typhoon Haiyan in San Pedro Bay

Figure 2.7. Difference in water levels of the modeled maximum surge height between Ty 1897 and Typhoon Haiyan in San Pedro Bay

Figure 2.8. Photos of storm damage around San Pedro Bay

Figure 2.9. Landfalling tropical cyclones in the surrounding area of Leyte Gulf between 1897 and 2013

\section{Chapter 3}

Figure 3.1. Track of Typhoon Haiyan and storm surge heights along the coastlines surrounding Leyte Gulf

Figure 3.2. Four transects were surveyed in Basey and Tanauan

Figure 3.3. Typhoon Haiyan caused significant geomorphic changes in Tanauan coast

Figure 3.4. Significant beach erosion following Typhoon Haiyan 
Figure 3.6. The washover sediments in Tanauan

Figure 3.7. Trench MP4 reveals two contrasting sand units that buried the pre-Haiyan soil surface

Figure 3.9. Trench MP6 and trench MP1

Figure 3.10. The washover sediments in Basey

\section{Chapter 4}

Figure 4.1. Track of Typhoon Haiyan and the measured storm surge and runup heights along the eastern coast of Samar Island

Figure 4.2. Pre- and post-typhoon Haiyan satellite images and photos of Hernani town

Figure 4.3. Detailed map of the study area showing the samples taken across different coastal environments south of Hernani

Figure 4.4. Boulders on the reef flat surface south of Hernani

Figure 4.5. Estimated flow velocities recquired to initiate transport of a subaerial $(\mathrm{Sa})$, submerged $(\mathrm{Sm})$, or joint-bounded $(\mathrm{Jb})$ boulder

Figure 4.6. Lateral variation in thickness, texture, and composition of the Haiyan overwash sediments south of Hernani

Figure 4.7. Shallow trenches showing the distinct light-colored sediments deposited by Typhoon Haiyan (TH) conformably overlying a dark-brown, pre-Haiyan (pre-TH) soil cover

\section{Chapter 5}

Figure 5.1. Typhoon Durian crossing central Philippines

Figure 5.2. Landfalling tropical cyclones in the surrounding area of Lagonoy Gulf between 1897 and 2013

Figure 5.3. Geomorphology of the coast surrounding Lagonoy Gulf

Figure 5.4. Pre- and post-storm coastal geomorphology derived from satellite images

Figure 5.5. Two most prominent washover fans (terrace) on the barrier spit

Figure 5.6. Stratigraphy and vertical textural variation of the sedimentary units revealed in trenches TP8, TP7, TP6 and TP5

Figure 5.7. Trench TP4 showing foreset stratification, and slight coarsening upward sequence at the terminus of the washover fan Figure 5.8. Across-shore profile and lateral variation in thickness and grainsize of the Typhoon Durian washover deposit on the southern washover fan

Figure 5.9. Textural comparison of the washover deposits with surface sediments of the possible source environments

Figure 5.10. Internal stratigraphy across the southern washover fan revealed on a GPR profile

Figure 5.11. Internal stratigraphy across the northern washover fan revealed on a GPR profile

Figure 5.12. OSL signals of the sediment sample in trial pit TP7-1 


\section{List of Tables}

\section{Chapter 2}

Table 2.1. Measured maximum storm surge heights and runup points of ST Haiyan in eastern Leyte and southern Samar islands Table 2.2. Minimum barometric pressure of Ty 1897 recorded in Guiuan and Tanuan and the corresponding Current Intensity (CI)number and maximum wind speeds

\section{Chapter 3}

Table 3.1. Comparison of the hydrodynamics and sedimentary signatures of the Typhoon Haiyan storm surge, and other recent storms of comparable intensity

Table 3.2. Comparison of the hydrodynamics and sedimentary signatures of the Typhoon Haiyan storm surge, and two recent tsunami deposits from the 2011 Japan tsunami, and the 2006 Indonesia tsunami

Table 3.3. Comparison of the hydrodynamics and sedimentary signatures of the Typhoon Haiyan storm surge and the 2004 Indian Ocean tsunami in Indonesia, Malaysia, India, and Sri Lanka Table 3.4. Comparison of the hydrodynamics and sedimentary signatures of the Typhoon Haiyan storm surge and the 2004 Indian Ocean tsunami in Thailand

\section{Chapter 4}

Table 4.1. Description of boulder clasts on the reef flat south of Hernani

Table 4.2. Across transect summary of the deposit thickness, grainsize, and flow characteristics in Carmen, south of Hernani

\section{Chapter 5}

Table 5.1. Tropical cyclones with known storm surge occurrence 


\section{Summary}

Typhoon Haiyan tragically attests to the vulnerability of Philippine coasts to storm surge hazard. It has also highlighted the limited and patchy knowledge that exists on the impacts to immediately affected communities despite the high frequency of storm surges in the archipelago. Moving forward, this dissertation contributes to increasing the level of local and regional science-based knowledge by laying down groundwork on the geologic investigations of storm surge impacts in the Philippines.

Two recent storm events namely the 2006 Typhoon Durian (Reming) and the 2013 Typhoon Haiyan (Yolanda) provided an opportunity to study the geomorphic and sedimentologic imprints of storm surges and the resulting coastal overwash. This dissertation though primarily built upon a geological framework of storm surge has benefited considerably from the integration of multiple disciplines including meteorology, oceanography, coastal engineering, and history. Overall, the multi-disciplinary approach led to (1) local understanding of storm surge dynamics and the factors affecting the spatial variation of amplification leading to inundation overland; (2) characterization of the onshore geomorphic and sediment imprints within the bounds of hydrodynamic conditions and sediment transport processes; and (3) historicallyoriented investigation of storm surge heights and the geologic impacts to the coasts near typhoon landfalls in the Philippines. 


\section{Chapter 1}

\section{Introduction}

Landfalling tropical storms or typhoons carry strong winds, heavy rainfall and storm surges causing multiple hazards overland including riverine flooding, landslides, and coastal flooding (Lin et al., 2010). These hazards commonly result in damage to property and loss of life. Amongst these hazards, storm-surge induced flooding is the most deadly. An aggregate re-insurance-based natural hazards database indicates that of the storm-related hazards between 1950 and 2010, storm surges account for 73 percent of all fatalities with death tolls exceeding 100,000 in countries like Bangladesh and Myanmar (Wirtz et al., 2014).

\subsection{What is a storm surge?}

A storm surge is best considered as a low-angle dome of water (Fig. 1.1) rising above the normal astronomical tide that is pushed towards the shore by onshore winds and low pressure associated with a cyclone system (e.g. Needham and Keim, 2011). The low atmospheric pressure of cyclonic systems was previously regarded as the main driver of increased sea-level heights during typhoons (Algue, 1898). Low atmospheric pressure means there is less atmosphere pressing down from above, in effect, the sea rises, and as such, it is commonly called the inverse barometric effect. Later, Welander (1961) argued that low pressure accounts for only a relatively small component of the storm surge. He estimated that for every millibar $(\mathrm{mb})$ of air pressure reduction, there is a corresponding increase in sea level by one $\mathrm{cm}$. That is, for a $1 \mathrm{~m}$ storm surge, there has to be a drop in pressure by $100 \mathrm{mb}$. At present, the consensus is that wind stress 


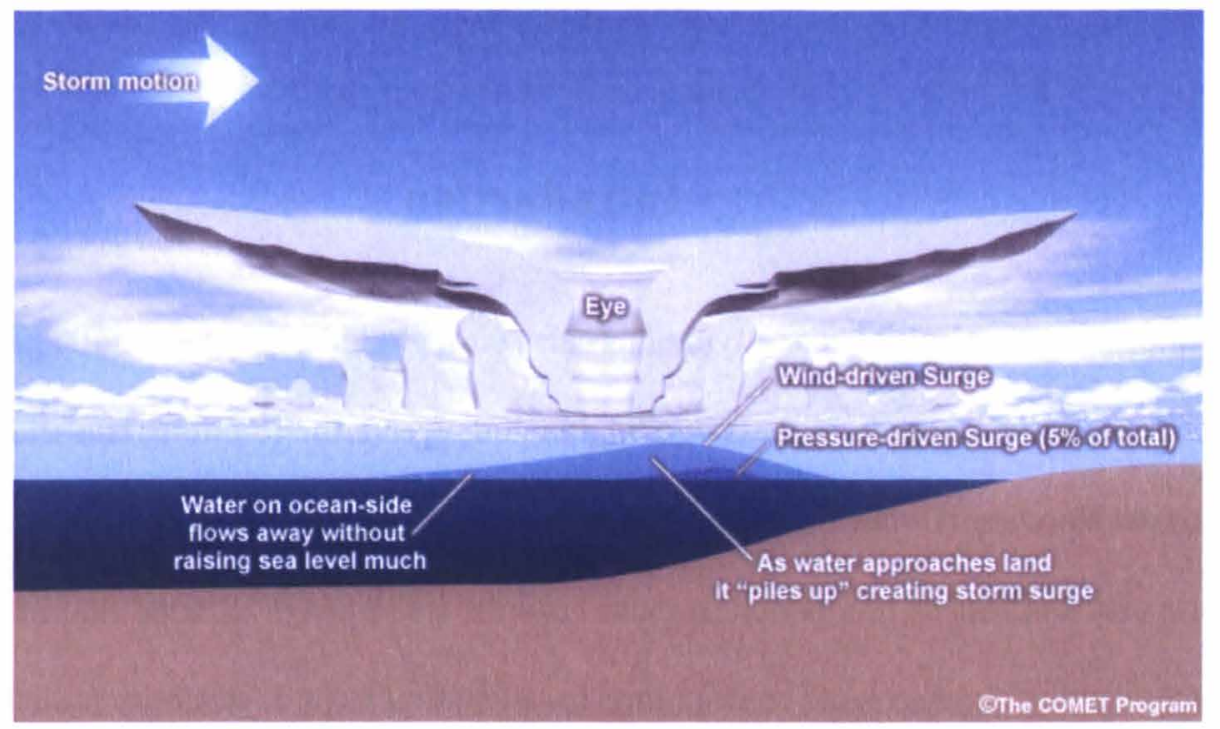

Figure 1.1. Diagram showing a tropical cyclone near landfall and the relative contribution of the wind and pressure components to a storm surge (from NOAA).

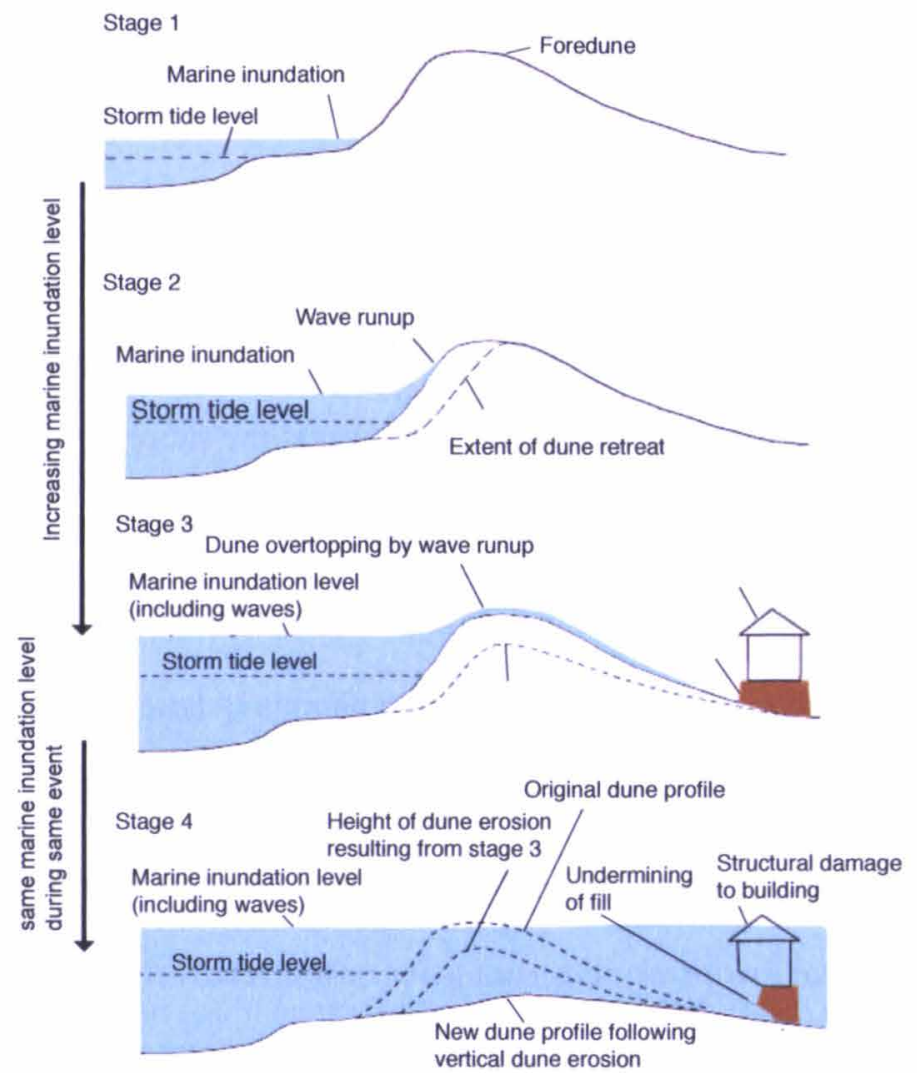

Figure 1.2. Increasing level of marine inundation resulting in increasing damage to the coastal landforms and infrastructures (from Nott and Hubbert, 2005). The combined storm tide, wave setup, and wave runup causes dune erosion, and/or overtopping that consequently exposes the adjoining community inland to the destructive power of the surge and sometimes to the direct impacts of breaking waves. 
dominates over low pressure in generating storm surges (Nott, 2006). Persistent onshore winds blow over the water surface and as soon as the onshore moving water comes in contact with the ocean floor, or the bathymetry is sufficiently shallow it starts to pile water up against the coast. As the storm approaches land, Nott (2006) noted a number of factors that can influence surge height including the intensity of the storm, the translational speed of the storm, radius of maximum winds, the angle of approach of the storm to the coast, offshore bathymetry, and the shape of the coastline. In most cases, it is not the dominance of one but a combination of these atmospheric, oceanographic, and geomorphological factors that will amplify or reduce the sea-level heights, and thus, determine whether the surge will or will not cause coastal flooding (Morton et al., 2000; Otvos, 2011).

Storm surge, however, cannot account for all the elevated water during coastal flooding. The total flood height is the aggregate of different components including surge, tide, and waves (Nott, 2006; Fig. 1.2). The dynamic coupling of storm surge and astronomical tide is referred to as the storm tide. Riding ontop of the storm tide, shortperiod breaking waves contribute to higher water levels through wave set up and wave runup. Wave set up is the additional elevation of water level from waves continuously breaking and piling up onshore. Wave runup is the highest elevation and most inland distance reached by the water from the breaking waves rushing up on the sloping beach profile (FEMA, 2005).

The combined destructive power of these breaking waves and the surge commonly cause damage to coastal communities during tropical cyclones (e.g. Nott and Hubbert, 
2005; FEMA, 2011). Storm surges can be deemed to be a natural hazard as the United Nation International Strategy for Disaster Reduction (UNISDR) defines a natural hazard as, "a potentially damaging physical event originating from geological, hydrometeorological and biological processes that may cause the loss of life or injury, property damage, social and economic disruption or environmental degradation." Notable recent storm surge events such as the 2005 Hurricane Katrina, 2008 Cyclone Nargis, 2012 Hurricane Sandy, and 2013 Typhoon Haiyan effectively illustrate the high cost of damage to properties and human lives sustained from storm surges (Woodruff et al., 2013; Wirtz et al., 2014; Soria et al., 2016). But just as storm surges can be undeniably destructive, such natural phenomena are also an important agent of coastal change by the action of remobilizing and depositing sediments through overwash processes (e.g. Donnelly et al., 2004; Nott and Hubbert, 2005; Wang and Horwitz, 2007).

\subsection{What is overwash?}

The term overwash is classically defined by Shephard and Wanless (1971) as "the transfer of beach sand across lagoonal side of the barrier through sluiceways during a hurricane or other violent storm". Leatherman (1981) expanded this definition from the transfer of beach sand to include any swash surge that overtops the highest points along a barrier, usually coinciding with the frontal dune line or the storm berm. These two definitions vary in the mechanism of overwash, one requires channelization (Shephard and Wanless, 1971) while the other requires overtopping (Leatherman, 1981). Building upon these principles, overwash was subsequently classified into two categories- runup overwash and inundation overwash (Sallenger, 2000). These categories are mainly established based on the relative heights between the high-water 


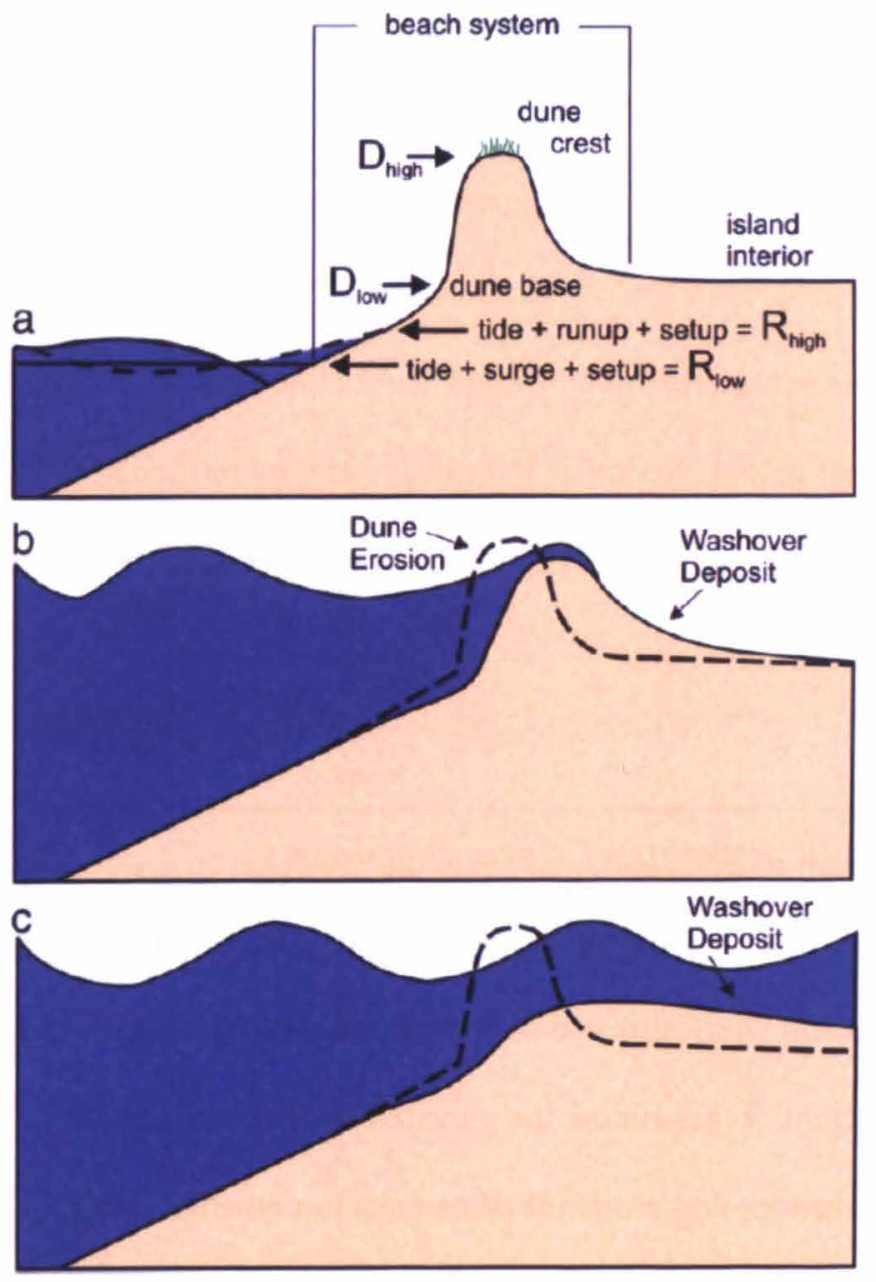

Figure 1.3. Overwash process on a barrier-island or beach system (from Williams, 2015). a) Relative heights of the storm-elevated water level from combined surge, tide, wave set-up, and wave runup (R) against the dune profile (D).

b) Runup overwash occurs when water level is just sufficient to overtop the dune creast causing dune erosion but limited inland penetration of flooding and washover deposition.

c) Inundation overwash occurs water level is exceedingly higher than the dune crest causing significant dune erosion, complete submergence of the beach system, and greater inland penetration of flooding and washover deposition. 
level from combined tide, surge, wave setup and wave runup against the dune or beach crest (Fig. 1.3). Essentially, runup overwash occurs when the high-water level is just sufficient to overtop the dune creast. Dune erosion occurs but to a limited extent. On the other hand, inundation overwash occurs when the high-water level is exceedingly higher than the dune crest thereby the entire dune or beach system is completely submerged. This is accompanied by significant dune erosion and flooding that penetrates farther inland. A similar but rather more quantified approach of the overwash process can be found in Donnelly and Sallenger (2007) and Donnelly and others (2006).

\subsection{Geomorphic imprints of storm overwash}

The geomorphic impact of storm overwash varies significantly depending on the local topography, coastal landforms and overwash magnitudes (Fig. 1.4). If an overwash event has sufficient excess runup, the elevated water level and the superimposed storm waves attack, overtop, and erode the dune crest to construct depositional landforms inland called washover fans (e.g. Pierce,1970). Although initially documented on barrier islands, washover fans can be practically seen in any low-lying, sandy beach system affected by storm surge (e.g. Schwartz, 1982; Sedgwick and Davis, 2003; Switzer and Jones 2008). The kinetic energy and the potential energy of these waves, by virtue of the onshore directed flow and by the height above still water cause the water with entrained sediments to flow inland towards the back barrier low-lying environments (Pierce, 1970). On land, the combined effects of friction, infiltration, and lateral spreading cause the flow velocity to decelerate towards the landward side of the barrier or spit, commencing the deposition of the entrained sediments (Donnelly and Sallenger, 2007). In plan view, the washover fans have a narrow throat as the apex, in 


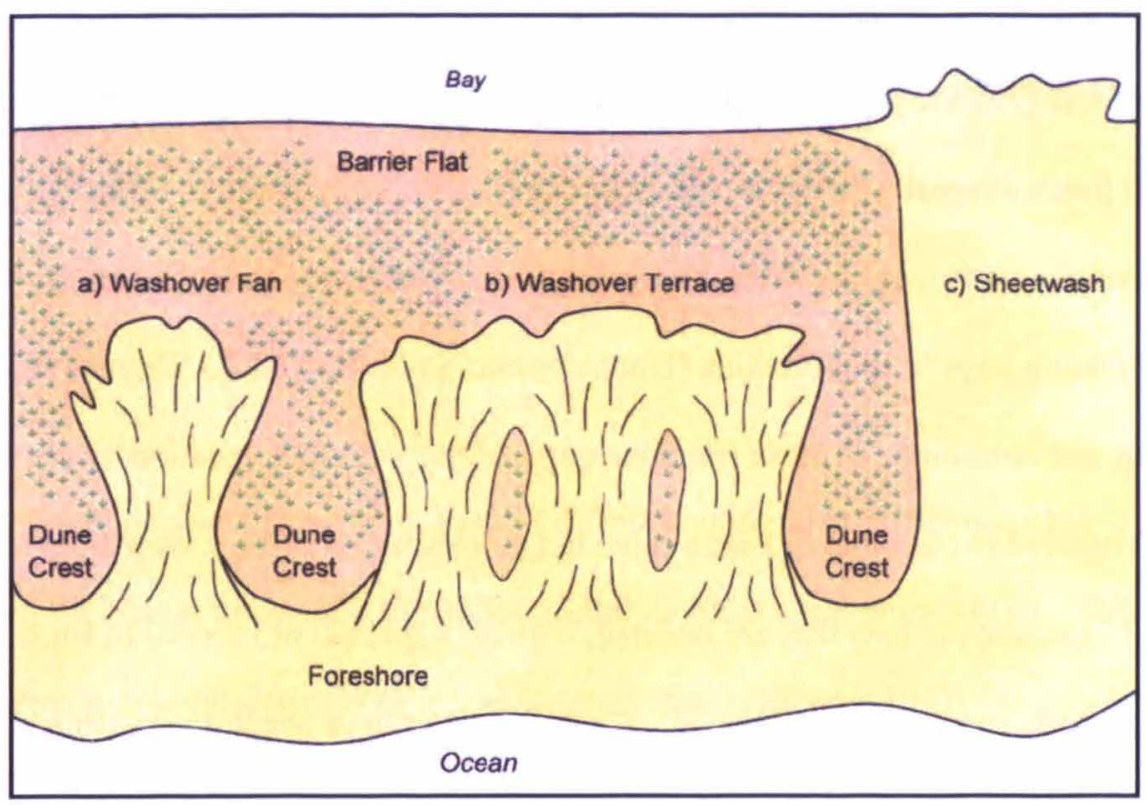

Figure 1.4. Plan view of landform elements in a dune system that sustained overwash (from Donnely et al., 2004). Shown are the typical morphologies of overwash deposits including (a) washover fan, (b) washover terrace, and (c) sheetwash.
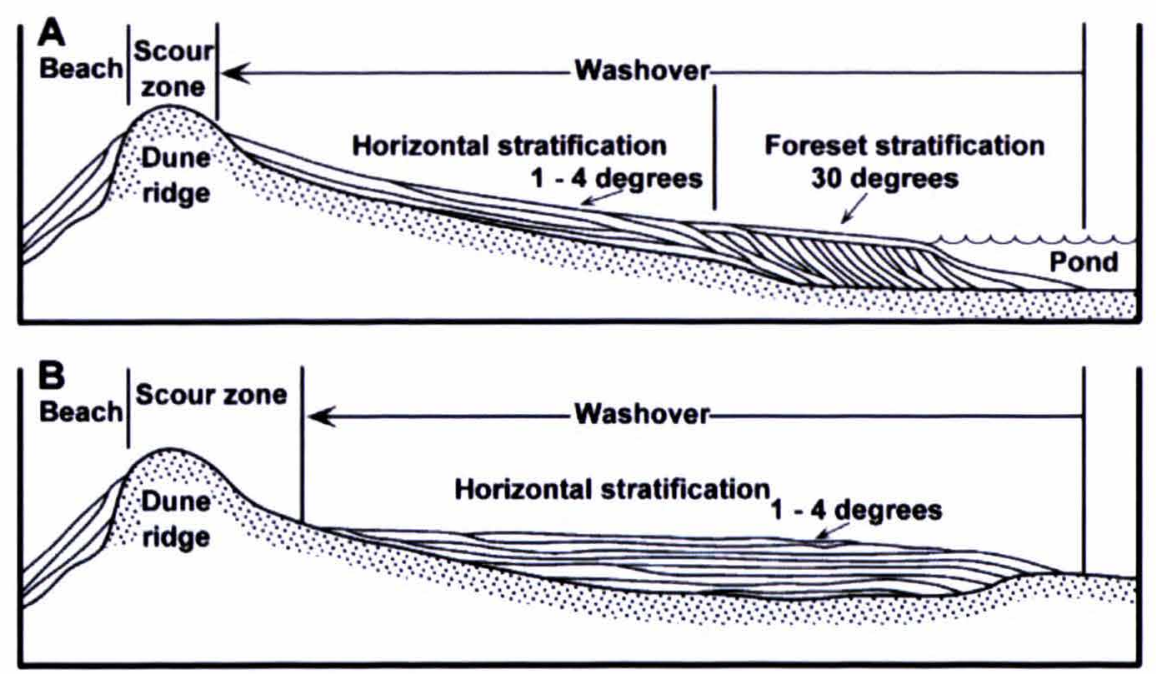

Figure 1.5. Cross-shore profile of a generalized washover fan stratigraphy showing (A) foreset laminae at the terminus of the fan during subaqueous deposition and (B) planar-laminae during supratidal deposition (from Sedgwick and Davis, 2003). 
most cases, and laterally spread landwards behind the dune or beach ridge to either lobate, parabolic, or flame-shaped margin (Leatherman, 1981; Otvos, 2011). Donnelly and others (2004) hypothesized that overwash can be funneled through existing gaps or lower areas along the foredune serving as the throat. Supporting evidence was shown such as the washover fans from Hurricane Isabel that were found coinciding with the pre-existing gaps in the foredune (Donnelly and Sallenger, 2007). Depending on the extent and continuity of these foredune gaps, along with the elevation of water surface level relative to the dune or beach ridge height (Sallenger, 2000), overtopping can result in washover fans that are isolated, regularly spaced, or merged to form terrace morphology (Morton and Sallenger, 2003). Sheetwash or sheet overwash is another morphological feature which is formed during complete inundation when there is a continuous flow of water over the entire dune crest causing vertical erosion of the dune. In extreme cases, persistent wave attack during inundation can completely remove dune ridges such as the impact caused by 1999 TC Vance in Western Australia (Nott and Hubbert, 2005). The eroded beach or dune sands are transported and deposited inland, spreading laterally on the backshore environments as a splay or sheet.

\subsection{Sedimentologic imprints of storm overwash}

The overwash sediments, sometimes also referred to as washover deposits, are commonly reported as anomalous sand layers found in the sedimentary environments of low-energy coastal settings, including coastal lakes, swamps and back-barrier tidal marshes (e.g. Leatherman, 1977; Liu and Fearn, 1993; Donnelly et al., 2004; Buynevich et al., 2004). Sand units deposited from recent intense storms are usually coarse grained and form a sharp erosional contact with the pre-existing fine-grained 
sediments on the adjacent marsh or coastal woodland environments (e.g. Horton et al., 2009; Williams, 2009; Hawkes and Horton, 2012). Within sand sequences of beach ridges, however, sediments from storm events do not necessarily have to be anomalous sands but can be coarser grained, coarse skewed units with sharp erosional contact with the underlying sandy pre-storm soil surfaces (Nott et al., 2013).

Washover deposits commonly exhibit different internal stratification (Fig. 1.5). For example, planar horizontal to subhorizontal laminae are commonly described in modern washover deposits (e.g. Leatherman and Williams, 1977; Switzer and Jones, 2008; Williams, 2009). Foreset stratification is not universal, but whenever present it is most often found at the terminus of the washover fan and associated with subaqueous deposition in a tidal channel, pond, or lagoon (Sedgwick and Davis, 2003). The variations of flow energy during the overwash process are hypothesized to result in vertical textural trends within the washover deposits such as fining upwards or coarsening upwards (Horton et al., 2009; Nott et al., 2013). The integrity of these sedimentary structures, however, may be compromised by bioturbation or postdepositional erosion ( Sedgwick and Davis, 2003; Otvos, 2011).

In the literature, the terms overwash and washover have been used interchangeably when refererring to sediments, which can be confusing. Following the original definitions, these terms although closely related actually refer to two different things (Leathermann, 1981). Overwash refers to the process, whereas washover refers to the landform, which is usually fan-like, created by overwash. In this sense, the term washover deposit from hereon in the text will be confined to the sediments within the 
washover fans or terraces, otherwise, the sediments will be referred to generally as overwash deposit.

\subsection{Carbonate coastlines}

Thus far, the majority of the previously described geomorphic and sedimentologic imprints pertain to clastic coastlines but may not necessarily be true for carbonate coastlines. Coral reefs are considered the frontline of defence against wave attack on most tropical carbonate coastlines. In most cases, coral reefs reduce wave height and significantly dissipate wave energy that would otherwise impact shorelines (Ferrario et al., 2014). But like any defence structures, reefs may also fail during extreme highenergy events (Roeber and Bricker, 2015). Regardless of the effectiveness to wave reduction, reefs are unequivocally exposed to wave attack and are vulnerable to storm impacts.

High-energy waves such as during stormy conditions can be either a destructive or a constructive force that modifies reef sedimentation (e.g. Scheffers and Scheffers, 2006; Etienne and Terry, 2012; Atwater et al., 2014). The commonly observed post-typhoon impacts on intertidal environments are the formation of coral rubble ridges (e.g. Spiske and Halley, 2014; Reyes et al., 2015) and the transport and deposition of conspicuous boulders mostly reefal clasts onto the reef flat (e.g. Terry et al., 2013; May et al., 2015; Kennedy et al., 2016). Strong waves can break living coral reef assemblages or rework pre-existing accumulations of rubble in shallow reef waters to form coral rubble ridges (Nott, 2006). Local geomorphic settings such as shallow sloping, particularly wide reef front, and leeward shores with lower wave energy were noted to normally favour the 
formation of coral rubble ridges (e.g. Nott and Hayne, 2001). Moreover, extreme wave impact can also excavate boulders or blocks on the reef front and if wave energy is sufficiently strong the dislodged reef boulders can be transported onto or across the reef flat ( Fig.1.6; Terry et al., 2013).

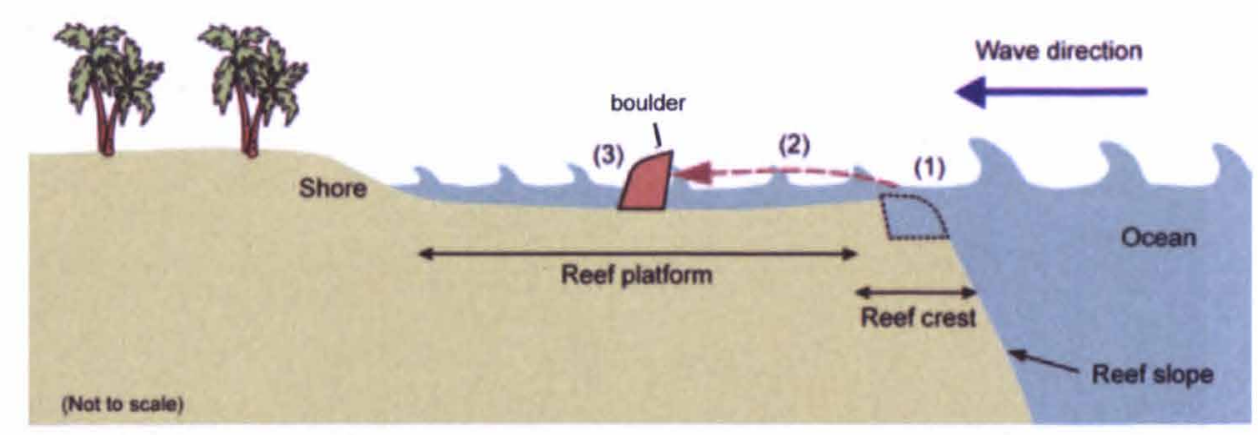

Figure 1.6. Schematic diagram showing high-energy wave action as one possible mode of formation for a reef-platform coral boulder (taken from Terry et al., 2013). High-energy wave action can detach (1), transport (2) and then deposit (3) a boulder on the reef platform.

\subsection{Storm surges in the Philippines}

1.6.1 What do we know?

The Philippine archipelago is inherently prone to storm surges as it is located along the path of seasonal typhoons generated from the northwest Pacific (Fig. 1.7). The state agency PAGASA (Philippine Atmospheric, Geophysical and Astronomical Services Administration) has a compilation list and a map of the historical storm surge occurrences in the Philippines between 1897 and 2011 (Appendix 1-2). But apart from the October 1897 typhoon (Algue, 1898), we lack detailed studies on the nature and local impact of historical storm surges. To many local coastal communities, little was known on the likely immediate and commonly devastating impacts of storm surge until the Typhoon Haiyan disaster in 2013. 


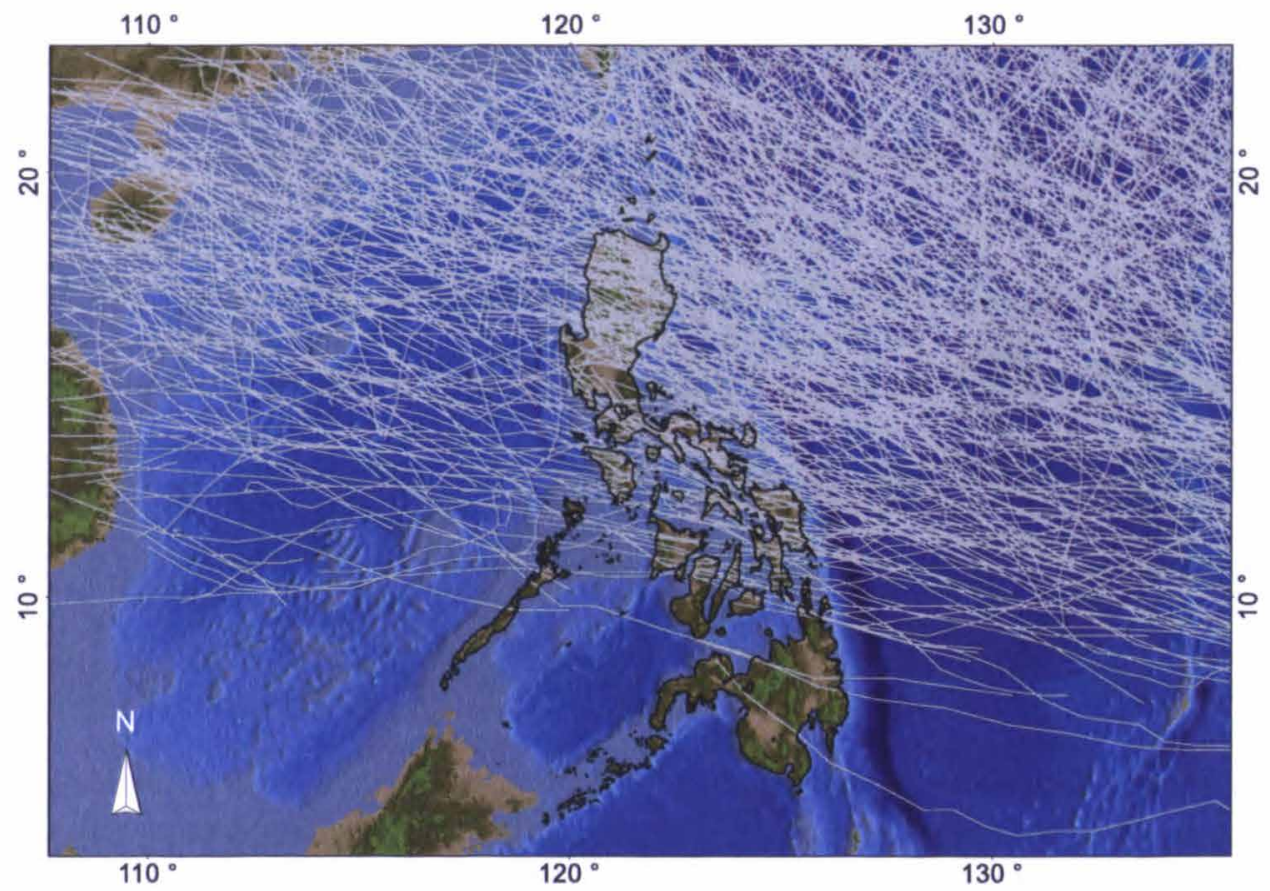

Figure 1.7. Storm tracks (gray lines) of landfalling typhoons ( $>64 \mathrm{kt}$ max 1 min-sustained wind speed) in the Philippines. Storm track data from IBTrACS database covering the period 1884 to 2014 .

In the aftermath of Typhoon Haiyan, Lapidez and others (2015) combined typhoon track data from 1951 to 2013 with numerical simulations of Haiyan - like magnitude typhoons to identify coastal areas in the Philippines most likely to be impacted by storm surges. The study of Lapidez and others (2015) concluded that areas likely hit by storm surges higher than $3 \mathrm{~m}$ are the small islands in central Philippines, the southern coast of Luzon including Metro Manila, and the northeastern coast of Mindanao.

These areas share common characteristics including gently sloping coasts, presence of shallow bays, and high frequency of typhoon landfalls since 1951. For the most part, this regional model identified the areas similarly indicated on the historical storm surges map of PAGASA to have been impacted by storm surges exceeding $1 \mathrm{~m}$ to $4 \mathrm{~m}$. 
The recent study, however, failed to replicate the historical occurrences of notable storm surges exceeding $4 \mathrm{~m}$ along the coast of northern Luzon and the entire coast of Catanduanes Island in central eastern Philippines. The apparent disparity of the regional model from that of the historical storm surge record highlights the need for site-specific studies of local coverage.

\subsubsection{What do we not know?}

In as much as storm surge modelling is a powerful tool to simulate storm surges and to hindcast and forecast coastal inundation scenarios, post-typhoon surveys are equally crucial for validation of the storm surge models, impact assessment, and long-term coastal planning (Nott and Hubbert, 2005). The first order of impact assessment typically includes an inventory of casualties, damage to properties and infrastructures, high-water marks, and inundation limits (e.g. FEMA, 2006; Fritz et al., 2009; Tajima et al., 2014; Mas et al., 2015). It is also important to record geomorphic and sedimentological impacts in response to such high-energy events. For example, beach and dune erosion are the most common tangible and documented impacts of storms and storm surges on the coast (e.g. Gardner et al., 1991; Nott and Hubbert, 2005; Wang et al., 2006; Shaw et al., 2015). In the Philippines, storms have been recognized as one major driver of changes in shoreline positions over the past decades, but detailed geological investigations remain scarce (e.g. Berdin et al., 2004; Siringan et al., 2010; Siringan et al., 2012). It is fundamental to document the coastal impacts of specific storms to compare and contrast how coastal systems respond to different storm events (Houser and Hamilton, 2008). 
This dissertation addresses the lack of geological investigation of storm surge impacts in the Philippines through a series of case studies. The primary objective is to document and describe the geomorphic and sedimentological imprints of two recent storm surge events along the central eastern Philippine coastlines, namely the 2006 Typhoon Durian and the 2013 Typhoon Haiyan (Fig. 1.8). Secondary objectives are to provide actual field observations of inundation heights for augmenting and validating storm surge models and to investigate storm surge imprints preserved on coastal sediment sequences that are similar to the recent examples. This study will pave the way to extend our record of inundation occurrences beyond historical time.

The storm surge events associated with the 2006 Typhoon Durian and the 2013 Typhoon Haiyan are the main focus of this study. We chose these events primarily because of their recent occurrence. Additional considerations were the storm surge magnitude, overwash regime, sediment lithology, and availability of historical storm surge information. Both Typhoon Durian and Typhoon Haiyan generated storm surges but of contrasting overwash regimes. Typhoon Durian corresponds to a runup overwash, whereas the sites studied for Typhoon Haiyan typify inundation overwash. The coastal areas impacted by Typhoon Haiyan and Typhoon Durian encompasses a suite of coastal lithologies including siliciclastic, carbonate, and mixed carbonate-siliciclastic landscapes, which comprehensively represent the sedimentological heterogeneity on sandy coastal environments in the tropics. The sediment characteristics of these recent storm surge events were analysed to gain deeper insights on the relationship between sediment transport and overland flow dynamics. Several independent dataset including field evidence, eyewitness 


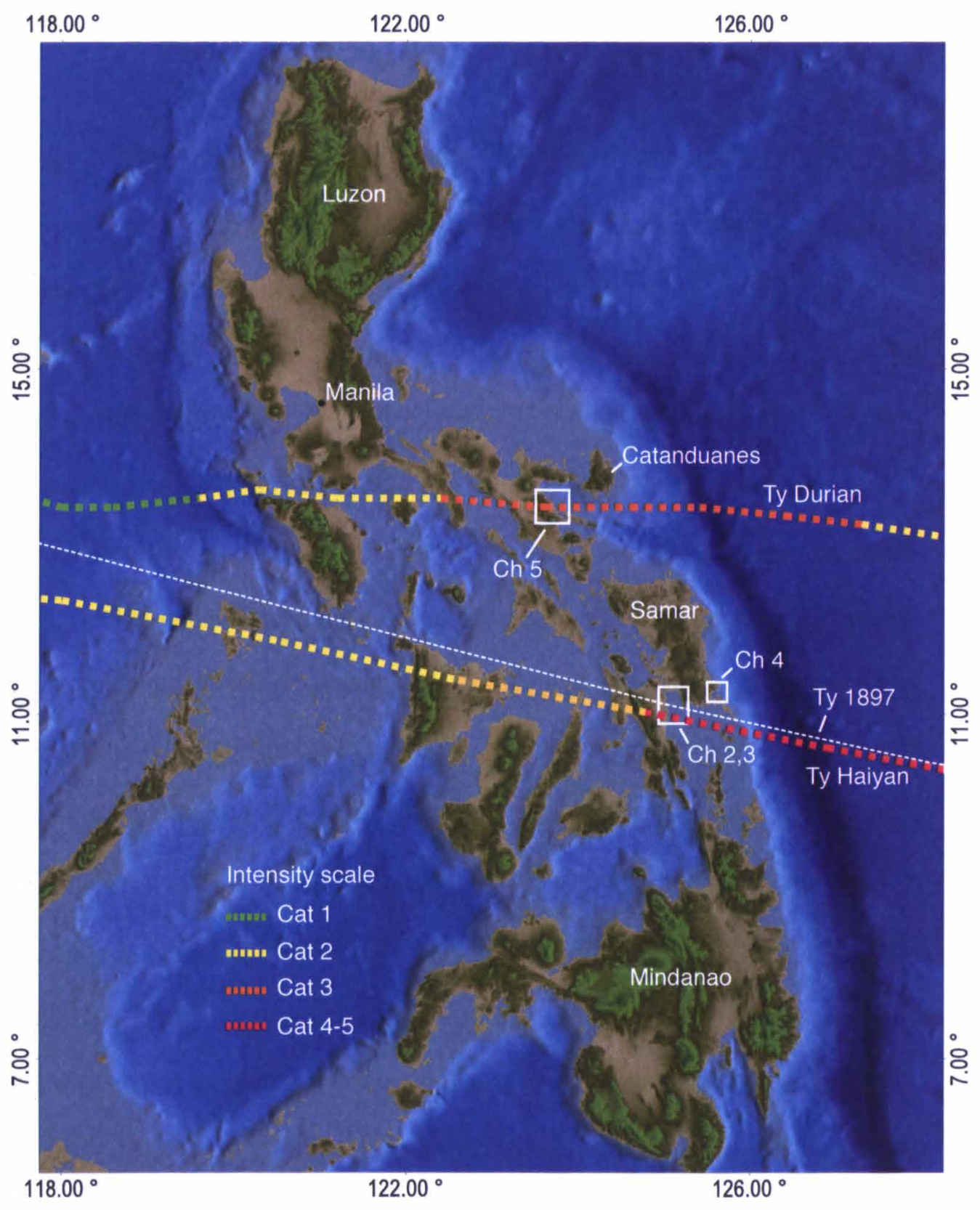

Figure 1.8. Philippine map showing the tracks of the typhoons (at equivalent intensity on the Saffir Simpson Hurricane Scale) and the specific areas covered in each chapter. 
accounts, and computer simulations were integrated to provide a cohesive story.

\subsection{Thesis structure}

This dissertation is divided into four independent manuscripts presented successively as chapters, each featuring one specific case study. The conceptualization, methods, results and synthesis described in the chapters are direct outcomes of my own research, however, contributions from co-authors have been invaluable and their input is also detailed at the start of each chapter.

Chapter 2 presents evidences that the November 2013 Typhoon Haiyan was a repeat disaster of the October 1897 unnamed typhoon. The report of Algue (1898) comprehensively documents an October 1897 unnamed typhoon, which provided a historical context for Typhoon Haiyan. The two typhoons followed a similar track warranting direct comparison between the magnitude and impacts of these two storm surge events in Samar and Leyte islands. This case study was published in the Bulletin of the American Meteorological Society (Appendix 3).

Chapter 3 describes the inland sedimentation pattern of Typhoon Haiyan along San Pedro Bay, a small embayment in the northwestern part of Leyte Gulf. The textural, compositional, and spatial trends of the overwash sediments were compared between two contrasting coastal landscapes, one dominated by siliciclastic lithology and the other dominated by mixed siliciclastic-carbonate lithologies. Given similar storm surge conditions, the local coastal geomorphology and geology strongly influence the overwash sediment composition and spatial distribution. In addition, the Haiyan overwash sediments were compared to other overwash sediments from 
recent tsunamis and storms in attempt to identify sedimentological characteristics that could be diagnostic.

Chapter 4 documents the Typhoon Haiyan sedimentation on the carbonate environment of the open-sea coastline of Hernani in Samar Island. At this location the storm surge deposited reef boulders on to the reef flat, while carbonate sands were transported farther inland and deposited on coconut groves and rice fields. The reef boulders and carbonate sands independently provide information to quantify overland flow characteristics of the storm surge using inversion models.

Chapter 5 describes the geomorphological features such as washover fans and terraces associated with a storm surge generated by Typhoon Durian in November 2006. This event affected a sandy volcaniclastic coast in Lagonoy Gulf. Six years following the breaching event, the washover fans and terraces remained evident with minimal modifications. These modern geomorphic and sedimentological imprints of storm surge inundation were used as reference to investigate similar indicators of storm inundations in the past that are potentially buried on the barrier spit surface but can be revealed from ground penetrating radar (GPR) imaging.

Chapter 6 summarises the key findings and highlights the implications to overwash sedimentation studies particularly in interpreting paleo-inundation events. This chapter also outlines the limitations and potential further studies in the field. 


\section{References}

Algué, J., 1898: El baguio de Samar y Leyte, 12-13 de Octubre de 1897, Manila Observatory, 1-74.

Atwater, B. F., Fuentes, Z., Halley,R. B., Ten Brink, U. S., and Tuttle, M. P., 2014. Effects of 2010 Hurricane Earl amidst geologic evidence for greater overwash at Anegada, British Virgin Islands. Adv. Geosci. 38, 21-30.

Berdin, R., Remotigue, C.T., Zamora, P., and Siringan, F.P., 2004, July. Coastal erosion vulnerability mapping along the southern coast of La Union, Philippines. Paper presented at the Global Symposium for Hazard Risk Reduction: Lessons Learned from the Applied Research Grants for Disaster Risk Reduction Program, Washington, DC (pp. 51-67). Washington DC: Provention Consortium, World Bank.

Buynevich, I.V., Fitzgerald, D.M., Van Heteren, S., 2004. Sedimentary records of intense storms in Holocene barrier sequences, Maine, USA. Marine Geology $210,135-148$

Donnelly, C., N. Kraus, and M. Larson, 2006: State of knowledge on measurement and modeling of coastal overwash. Journal Coastal Res. 22, 4, 965-991.

Donnelly, C., Sallenger, A.H., 2007. Characterisation and modeling of washover fans. Proceedings of Coastal Sediments '07, USACE, New Orleans, USA, pp. 20612073.

Donnelly, J.P., Butler, J., Roll, S., Wengren, M., Webb, T., III, 2004. A backbarrier overwash record of intense storms from Brigantine, New Jersey. Marine Geology 210, 107-121.

Etienne S., and Terry J.P., 2012. Coral boulders, gravel tongues and sand sheets: features of coastal accretion and sediment nourishment by Cyclone Tomas (March 2010) on Taveuni Island, Fiji. Geomorphology 175-176, 54-65.

Federal Emergency Management Agency (FEMA), 2006. High Water Mark Collection for Hurricane Katrina in Alabama. FEMA-1605-DR-AL, Task Orders 414 and 421. Federal Emergency Management Agency, Atlanta, GA.

Federal Emergency Management Agency (FEMA), 2011. Coastal Construction Manual FEMA-P55 Vol. 1, U.S. Department of Homeland Security, 3-31 - 3- 
34.

Ferrario, F., Beck, M. W., Storlazzi, C. D., Micheli, F., Shepard, C. C., and Airoldi, L., 2014. The effectiveness of coral reefs for coastal hazard risk reduction and adaptation. Nat. Commun. 5, 3794. doi: 10.1038/ncomms4794.

Fritz, H.M., C.D. Blount, S., Thwin, M.K. Thu, and N. Chan, 2009: Cyclone Nargis storm surge in Myanmar. Nature Geoscience 2, 448-449.

Gardner, L.R., Michener, W.K., Kjerfve, B., and Karinshak, D.A., 1991. The geomorphic effects of Hurricane Hugo on an undeveloped coastal landscape at North Inlet, South Carolina. Journal of Coastal Research 8, 181-186.

Hawkes, A.D., Horton, B.P., 2012. Sedimentary record of storm deposits from Hurricane Ike, Galveston and San Luis Islands, Texas. Geomorphology 171 172, 180-189.

Horton, B.P., Rossi, V., Hawkes, A.D., 2009. The sedimentary record of the 2005 hurricane season from Mississippi and Alabama coastlines. Quaternary International 195, 15-30.

Houser, C., Hapke, C., Hamilton, S., 2008. Controls on coastal dune morphology, shoreline erosion and barrier island response to extreme storms. Geomorphology 100, 223-240.

Kennedy, A. B., Mori, N., Zhang, Y., Yasuda, T., Chen, S., Tajima, Y., Pecor, W., and Toride, K., 2016. Observations and modeling of coastal boulder transport and loading during Super Typhoon Haiyan. Coastal Engineering Journal 58(1), $16400051-27$.

Lapidez, J. P., Tablazon, J., Dasallas, L., Gonzalo, L. A., Cabacaba, K. M., Ramos, M. M. A., Suarez, J. K., Santiago, J., Lagmay, A. M. F., and Malano, V., 2015. Identification of storm surge vulnerable areas in the Philippines through the simulation of Typhoon Haiyan-induced storm surge levels over historical storm tracks, Nat. Hazards Earth Syst. Sci. 15, 1473-1481, doi:10.5194/nhess-151473-2015.

Leatherman, S.P., Williams, A. T., 1977. Lateral textural grading in overwash sediments. Earth Surface Processes 2, 333-341. 
Leatherman, S.P., 1981. Overwash processes. Benchmark papers in Geology, Vol. 58. Hutchinson Ross Publishing Co., USA. 376 pp.

Lin, I.-I., Pun,I.-F., and Lien, C.-C., 2014. "Category-6" supertyphoon Haiyan in global warming hiatus: Contribution from subsurface ocean warming, Geophys. Res. Lett., 41, 8547-8553 doi:10.1002/2014GL061281.

Liu, K-b., Fearn, M. L., 1993. Lake-sediment record of late Holocene hurricane activities from coastal Alabama. Geology 21, 793-796.

Mas, E., J. Bricker, S. Kure, B. Adriano, C. Yi, A. Suppasri, and S. Koshimura, 2015: Field survey report and satellite image interpretation of the 2013 Super Typhoon Haiyan in the Philippines. Nat. Hazards Earth Syst. Sci. 15, 805-816, doi:10.5194/nhess-15-805-2015.

May, S.M., Engel, M., Brill, D., Cuadra, C., Lagmay, A.M.F., Santiago, J., Suarez, J.K., Reyes, M., and Brückner, H, 2015. Block and boulder transport in Eastern Samar (Philippines) during Supertyphoon Haiyan. Earth Surface Dynamics 3, 543-558.

Morton, R.A. Gonzalez, J.L., Lopez, G.I., and Correa, I.D., 2000. Frequent non-storm washover of barrier islands. Pacific coast of Columbia. Journal of Coastal Research, 16(1), 82-87.

Morton, R.A., Sallenger, A.H., 2003. Morphological impacts of extreme storms on sandy beaches and barriers. Journal of Coastal Research 19, 560-573.

Needham, H. and Keim, B.D., 2011. Storm Surge: Physical Processes and an Impact Scale. In Prof. Anthony Lupo (Ed.), Recent Hurricane Research - Climate, Dynamics, and Societal Impacts. Intech, pp. 385-406. Available from: http://www.intechopen.com/ books/recent-hurricane-research-climatedynamicsand-societal-impacts/storm-surge-physical-processes-and-an-impactscale.

National Oceanic and Atmospheric Administration, NOAA. Storm surge overview. Accessed 26 May 2016. Available online at http://www.nhc.noaa.gov/surge/.

Nott, J. 2006. Extreme events: A physical reconstruction and risk assessment. Cambridge University Press. 297 pp.

Nott, J., Chague-Goff, C., Goff, J., Sloss, C., Riggs, N., 2013. Anatomy of sand beach 
ridges: Evidence from severe Tropical Cyclone Yasi and its predecessors, northeast Queensland, Australia, Journal of Geophysysical Research: Earth Surface 118, 1710-1719, doi:10.1002/jgrf.20122.

Nott, J., and Hayne, M., 2001. High frequency of 'super-cyclones' along the Great Barrier Reef over the past 5,000 years. Nature 413, 508-512.

Nott, J., and Hubbert, G., 2005. Comparisons between topographically surveyed debris lines and modelled inundation levels from severe tropical cyclones Vance and Chris, and their geomorphic impact on the sand coast. Australian Meteorological Magazine 54,187-196.

Otvos, E.G., 2011. Hurricane signatures and landforms - toward improved interpretations and global storm climate chronology. Sedimentary Geology 239, $10-22$.

Pierce, J.W., 1970. Tidal inlets and washover fans. The Journal of Geology 78(2), 230-234.

Roeber, V. and Bricker, J., 2015. Destructive tsunami-like wave generated by surf beat over a coral reef during Typhoon Haiyan. Nature Communications 6, 7854. doi: $10.1038 /$ ncomms 8854 .

Sallenger, A.H. Jr., 2000. Storm impact scale for barrier islands. Journal of Coastal Research 16(3), 890-895.

Scheffers, A., and Scheffers, S., 2006. Documentation of the imoact of Hurricane Ivan on the coastline of Bonaire (Netherlands Antilles). Journal of Coastal Research 22(6), 1437-1450.

Schwartz, R.K., 1982. Bedform and stratification characteristics of some modern small-scale washover sand bodies. Sedimentology 29, 835-849.

Sedgwick, P. E., Davis. R. A. Jr., 2003. Stratigraphy of washover deposits in Florida: implications for recognition in the stratigraphic record. Marine Geology 200, $31-48$.

Shaw,J., You, Y., Mohrig, D., and Kocurek, G., 2015 Tracking hurricane-generated storm surge with washover fan stratigraphy. Geology 43(2), 127-130.

Shepard, Francis P., and Harold R. Wanless. 1971. Our changing coastlines. New 
York: McGraw-Hill. 579 pp.

Siringan, F.P., Soria, J.L.A., and Ramos, R.D. 2010, December. Changes in shoreline positions and vulnerability to marine flooding of the Verde Island Passage Corridor, Southern Luzon. Paper presented at the First Joint International Conference of IGCP588 and INQUA1001. University of Hong Kong.

Siringan, F.P., Soria, J.L.A., Jordan, J.C., and Zamora, P.B., 2012. Water resource and hazards assessment in Tiwi, Albay. In Albay Sustainable Development Guidebook, pp. 29-58. Manila Observatory, Chevron Geothermal Philippines Inc., Albay Provincial Government.

Soria, J.L.A., Switzer, A.D., Villanoy, C.L., Fritz, H.M., Bilgera, P.H.T., Cabrera, O.C., Siringan, F.P., Yacat-Sta. Maria, Y., Ramos, R.D., Fernandez, I.Q., 2016. Repeat storm surge disasters of Typhoon Haiyan and its 1897 predecessor in the Philippines. Bulletin of the American Meteorological Society 97(1), 31-48. doi, 10.1175/BAMS-D-14-00245.1

Spiske, M. and Halley, R. B., 2014. A coral-rubble ridge as evidence for hurricane overwash, Anegada (British Virgin Islands). Advances in Geosciences 38, 9 20.

Switzer, A. D., and Jones, B. G., 2008. Setup, deposition, and sedimentary characteristics of two storm overwash deposits, Abrahams Bosom Beach, Southeastern Australia. Journal of Coastal Research 24(sp1), 189-200.

Switzer, A. D., S. Srinivasalu, N. Thangadurai, and V. Ram Mohan, 2012. Bedding structures in Indian tsunami deposits that provide clues to the dynamics of tsunami inundation. Geological Society London Special Publications 361, 61 77. doi: $10.1144 / \mathrm{SP} 361.6$

Tajima, Y., and coauthors, 2014: Initial report of JSCE-PICE joint survey on the storm surge disaster caused by Typhoon Haiyan. Coastal Engineering Journal 5, doi:10.1142/S0578563414500065.

Terry, J.P., Lau, Annie A. Y., Etienne, S., 2013. Uncertainties and continuing challenges with interpreting coastal boulders. In: Reef-platform coral boulders evidence for high-energy marine inundation events on tropical coastlines. Springer Singapore. pp.70-72. 
Wang, P., and Horwitz, M.H., 2007. Erosional and depositional characteristics of regional overwash deposits caused by multiple hurricanes. Sedimentology 54 , $545-564$.

Wang, P., Kirby, J.H., Haber, J.D., Horwitz, M.H., Knorr, P.O., Krock, J.R., 2006. Morphological and sedimentological impacts of hurricane Ivan and immediate poststorm beach recovery along the northwest Florida barrier-island coasts. Journal of Coastal Research 22, 1382-1402.

Welander, Pierre, 1961: Numerical Prediction of Storm Surges. In H.E. Landsberg and J. van Mieghem (Eds.) Advances in Geophysics 8. Academic Press, Inc., New York, USA, $316 \mathrm{pp}$.

Williams H.F.L., 2009. Stratigraphy, sedimentology, and microfossil content of Hurricane Rita storm surge deposits in southwest Louisiana. Journal of Coastal Research 25(4), 1041-1051.

Williams, H.F.L., 2015. Contrasting styles of Hurricane Irene washover sedimentation on three east coast barrier islands: Cape Lookout, North Carolina; Assateague Island, Virginia; and Fire Island, New York. Geomorphology 231, 182-192.

Wirtz, A., Kron, W., Löw, P, and Steuer, M., 2014.The need for data: natural disasters and the challenges of database management. Natural Hazards 70, 135-157. doi 10.1007/s1 1069-012-0312-4.

Woodruff, J. D., Irish, J. L., \& Camargo, S. J., 2013. Coastal flooding by tropical cyclones and sea-level rise. Nature 504(7478), 44-52. 


\section{Chapter 2}

\section{Repeat storm surge disasters of Typhoon Haiyan and its 1897 predecessor in the Philippines}

Janneli Lea A. Soria ${ }^{1,2}$, Adam D. Switzer ${ }^{1,2}$, Cesar L. Villanoy ${ }^{3}$, Hermann M. Fritz ${ }^{4}$,

Princess Hope T. Bilgera ${ }^{3}$, Olivia C. Cabrera ${ }^{3}$, Fernando P. Siringan ${ }^{3}$, Yvainne Yacat-

Sta. Maria ${ }^{3}$, Riovie D. Ramos ${ }^{1,2}$, and Ian Quino Fernandez ${ }^{3}$

${ }^{1}$ Earth Observatory of Singapore, Nanyang Technological University 639798,

Singapore;

${ }^{2}$ Asian School of the Environment, Nanyang Technological University 639798,

Singapore

${ }^{3}$ Marine Science Institute, University of the Philippines, Diliman, Quezon City 1101 ,

Philippines

${ }^{4}$ School of Civil and Environmental Engineering, Georgia Institute of Technology,

Atlanta, GA 30332, USA

Published: Bulletin of American Society of Meteorologists (January 2016)

Key words: Haiyan, storm surge, Samar, Leyte Gulf, San Pedro Bay 


\section{Abstract}

On 8 November 2013, Typhoon Haiyan impacted the Philippines with estimated winds of approximately $314 \mathrm{~km} \mathrm{~h}^{-1}$ and an associated 5 to $7 \mathrm{~m}$ high storm surge that struck Tacloban City and the surrounding coast of the shallow, funnel-shaped San Pedro Bay. Typhoon Haiyan killed more than 6,000 people, superseding Tropical Storm Thelma (Uring) of November 1991 as the deadliest typhoon in the Philippines. Globally, it was the deadliest tropical cyclone since Cyclone Nargis hit Myanmar in 2008. Here, we use field measurements, eyewitness accounts and video recordings to corroborate numerical simulations and characterize the extremely high-velocity flooding caused by the Typhoon Haiyan storm surge in both San Pedro Bay and on the more open Pacific Ocean coast. We then compare the surge heights from Typhoon Haiyan with historical records of an unnamed typhoon that took a similar path of destruction in October 1897 (Ty 1897), but which was less intense, smaller, and moved more slowly. The Haiyan surge was about twice the height of the 1897 event in San Pedro Bay, but the two storm surges had similar heights on the open Pacific coast. Until stronger prehistoric events are explored, these two storm surges serve as worst-case scenarios for this region. This study highlights that rare but disastrous events should be carefully evaluated in the context of enhancing community-based disaster risk awareness, planning, and response. 


\subsection{Introduction}

Typhoon Haiyan affected more than 16 million people, killed 6,293 people and destroyed more than 1.1 million dwellings in the central Philippines (NDRRMC 2014). Haiyan is the deadliest typhoon recorded in the Philippines, superseding Tropical Storm Thelma that struck Ormoc City on the western coast of Leyte Island, in November 1991 (Alojado and Padua 2010, Bacani 2013, Ribera et al. 2008). Globally, Typhoon Haiyan was the deadliest cyclonic event since Cyclone Nargis devastated Myanmar in 2008 (Fritz et al. 2009). The damage to infrastructure and agriculture cost $\sim \mathrm{PhP} 40 \mathrm{~B}$ or $\sim$ US $\$ 900 \mathrm{M}$ (NDRRMC 2014), while the total economic loss reached up to US\$13B (Caulderwood 2014). The damage and death toll from Typhoon Haiyan were particularly high along the coasts surrounding San Pedro Bay on the northwestern margin of the Leyte Gulf primarily due to the storm surge generated by the typhoon. The shallow bathymetry of less than $10 \mathrm{~m}$ depth and funnel shape make the coasts of San Pedro Bay inherently susceptible to storm surge (Fig. 2.1 inset). Additional factors that contributed to local amplification of the storm surge in Leyte Gulf were the orientation of the typhoon track and associated seiches (Mori et al. 2014).

Eyewitnesses described the Haiyan storm surge as dramatically worse than any coastal flooding events in recent years (Amadore 2013). Longer historical records, however, reveal a comparable predecessor to Typhoon Haiyan (Algué 1898). In October 1897, an unnamed typhoon, which for brevity will be henceforth referred to as Ty 1897 , took a path across Leyte Gulf that was almost parallel to Typhoon Haiyan's, but offset to the 
north by $\sim 6 \mathrm{~km}$ (Fig. 2.1). The similar track enables direct comparison of the two typhoons and the storm surges. Here, we first characterize the destructiveness of Typhoon Haiyan before considering the importance of the 1897 predecessor in understanding storm surge hazard in the region.

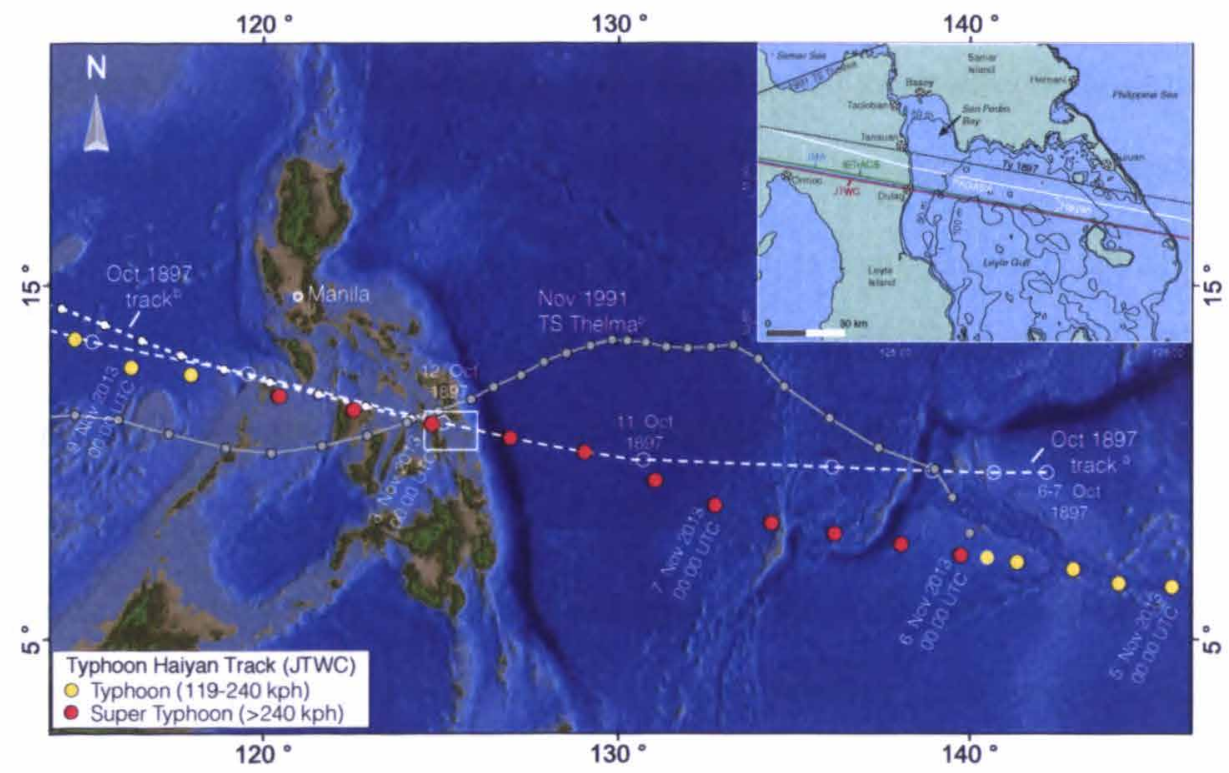

Figure 2.1. Storm tracks of three deadly typhoons crossing the central Philippines - Ty 1897, November 1991 TS Thelma, and November 2013 Super Typhoon Haiyan. Typhoon track sources: a) Algue (1898); b) IBTrACS database of Knapp et al. (2010). Inset: Comparative tracks of Ty 1897 (black dashed line) and Haiyan (colored solid lines) across Leyte Gulf.

\subsection{Typhoon Haiyan}

On 2 November 2013 a broad low-pressure area formed in the western Pacific, to the east of Micronesia (Joint Typhoon Warning Center 2014). By 0600 UTC on 3

November it had developed into a tropical depression. At 0000 on 4 November UTC, 
the system had attained tropical storm strength and was named Haiyan. It rapidly strengthened into a typhoon and moved west towards the Philippines (Fig. 2.1), where it was given the local name of Yolanda (NDRRMC 2013a). By November 6 Haiyan's 1 -minute maximum sustained winds had intensified to an estimated $241 \mathrm{~km} \mathrm{~h}^{-1}$, classified by the Joint Typhoon Warning Center (JTWC) as Super Typhoon. To avoid ambiguity in the definition of "Super Typhoon", we will conform to the traditional classification of tropical cyclones (World Meteorological Organization, 2015) in the Pacific region with "Typhoon".

On its final northwestward approach to the Philippines, Haiyan steadily intensified until it reached the peak intensity of $\sim 895 \mathrm{hPa}$ minimum central pressure. This peak intensity was estimated by the JTWC and the Japan Meteorological Agency (JMA) from cloud patterns recognized on visible and infrared satellite images, in the absence of ground and in-situ instruments. In Guiuan municipality on Samar Island, Doppler radar data of the Philippine Atmospheric Geophysical and Astronomical Services Administration (PAGASA) indicated that just before landfall, at 2000 on 7 November UTC ( 0400 on 8 November Philippine Time, PHT) Haiyan attained a minimum central pressure of 910 $\mathrm{hPa}$, and winds at $160 \mathrm{~km} \mathrm{~h}^{-1}$ with gusts of $\sim 195 \mathrm{~km} \mathrm{~h}^{-1}$ (Paciente 2014). Extreme winds destroyed the Guiuan Doppler radar station about 16 minutes later. At 2040 on 7 November UTC (0440 PHT 8 November), Haiyan crossed the small islands off the southeast tip of Samar Island, near Guiuan. Haiyan then continued westwards across the Leyte Gulf to its main landfall south of Tolosa, Leyte Island at 2300 on 7 
November UTC (0700 PHT 8 November), as captured by another PAGASA Doppler radar station in Cebu. Typhoon Haiyan then made four subsequent landfalls as it crossed the central Philippines (NDRRMC 2013b).

\subsection{Material and Methods}

We evaluated eyewitness accounts, video recordings, field measurements, and storm surge model hydrographs to document the flow depths, surge heights, timing and peak flood duration during Typhoon Haiyan, as well as the resulting damage. Other postHaiyan field survey reports focused on the inundation characteristics and the impact on coastal structures (Mas et al. 2015; Tajima et al. 2014). Here, we place Typhoon Haiyan's storm surge into a historical context by comparing it with the similar Ty 1897 event (Algué 1898).

\subsubsection{Field Survey}

The initial field survey of the coastal areas surrounding San Pedro Bay, was conducted from 23 to 28 November 2013 , as soon as relief operations and the security situation permitted access in the hardest hit areas. We recorded 73 eyewitness accounts (Appendix 3, Supplementary Table S1) on the maximum flow depth, the timing of the initial rise, peak and subsidence of the flood, along with wind and wave observations. Collected data were used to validate the timing and heights simulated by our storm surge models. Subsequent surveys from 16 to 25 January, 12 to 19 May and 2 to 10 June 2014 encompassed larger and more remote areas, including coastal 
settlements in southern Samar facing the Leyte Gulf and the Philippine Sea of the Western Pacific (Fig. 2.2, Table 2.1). To record distances and build cross-shore elevation profiles from the water surface at the shoreline to the inundation limit, water marks were located and measured with a Trimble Global Positioning System (GPS) rover connected via bluetooth to a Lasercraft XLRic ${ }^{\mathrm{TM}}$ laser range finder (Fritz et al 2012). At each site, high-water marks such as mudlines on buildings, scars on the bark of trees and rafted debris were evaluated using established protocols (Fritz et al. 2007; UNESCO 2014). In inhabited areas, the water marks were discussed with eyewitnesses to constrain still-water levels, estimate the contribution of storm waves, and remove bias from localized splash-up atop the surge. The high-water measurements, based on different indicators at corresponding locations, tended to be consistent and have an individual confidence of $\pm 0.1 \mathrm{~m}$. During post-survey processing, the measurements were differentially corrected with our daily setup of the local Ashtech ${ }^{\mathrm{TM}}$ base station and corrected for tide level at the time of peak storm surge on the basis of tide predictions provided by XTide 2 (C) open-source software of Flater (1998). How the Ty 1897 storm surge heights were measured remains unknown, but it is highly likely that surge heights were simply referenced to the mean sea level at the time of survey. The difference between the mean sea level and the sea level at the time of peak flood during Ty 1897 imply that the accuracy of surge height measurements is in the range of \pm 0.3 $\mathrm{m}$. Algué (1898) lacks description on the surge height indicators, but additional uncertainties can be potentially contributed by storm waves. 

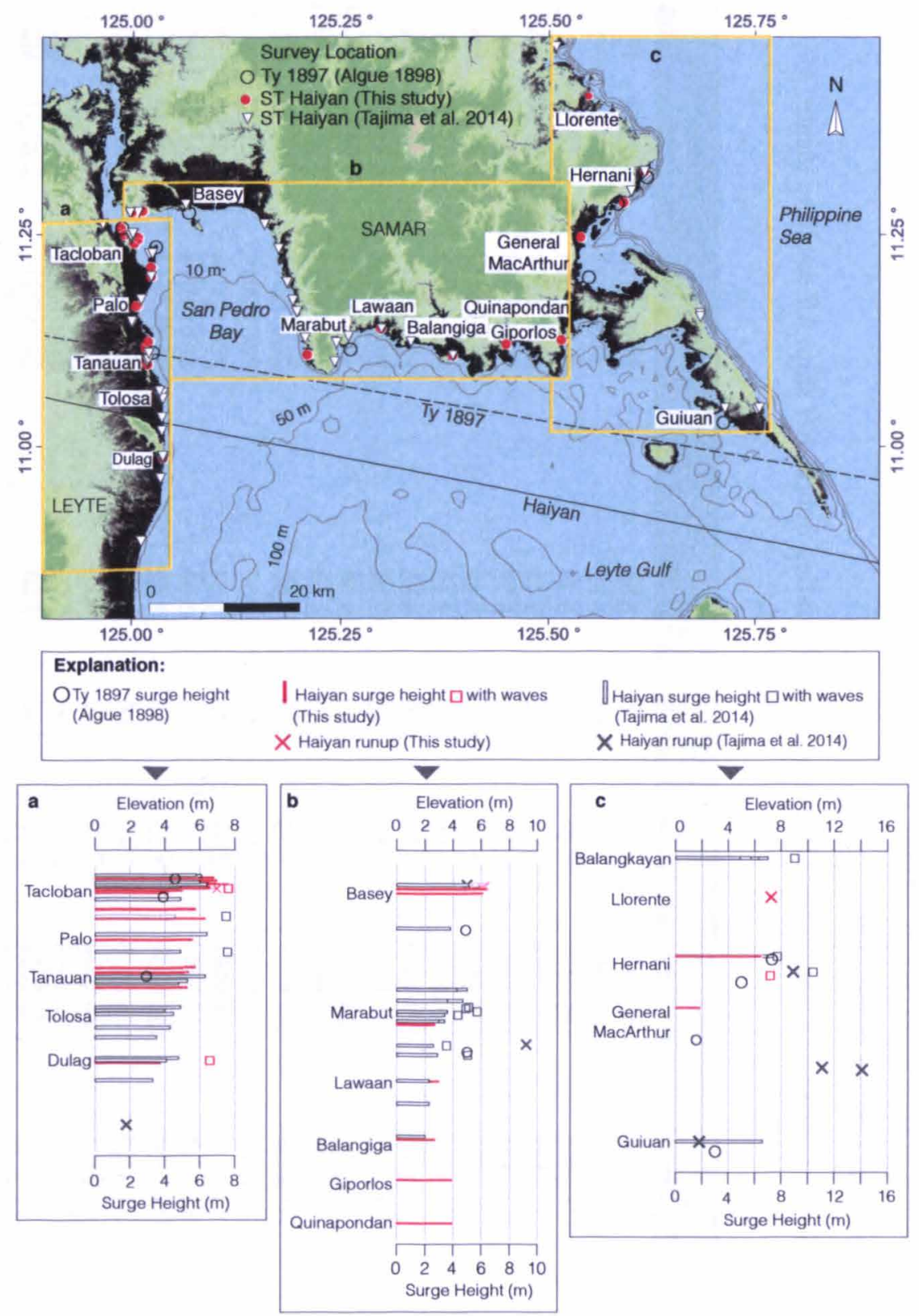

Figure 2.2. Maximum storm surge heights, surge with waves, and runup points of Typhoon Haiyan measured in the field across the coastal communities in eastern Leyte and Samar islands. Surge heights of Ty 1897 from Algue (1898) are included for comparison. The terrain map is a modified NASA land elevation radar image; dark shaded areas are $\leq 10 \mathrm{~m}$, above sea level. 


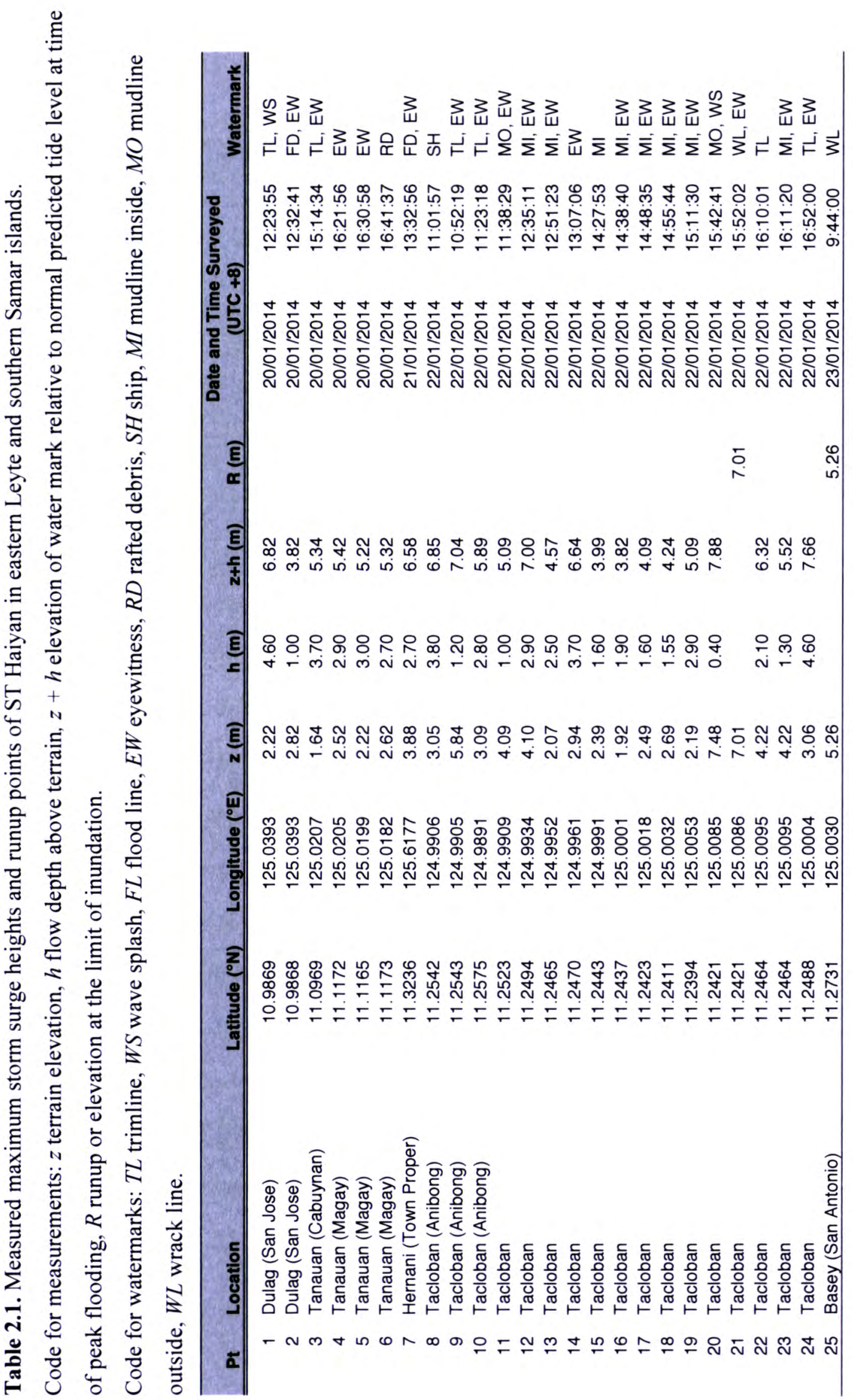




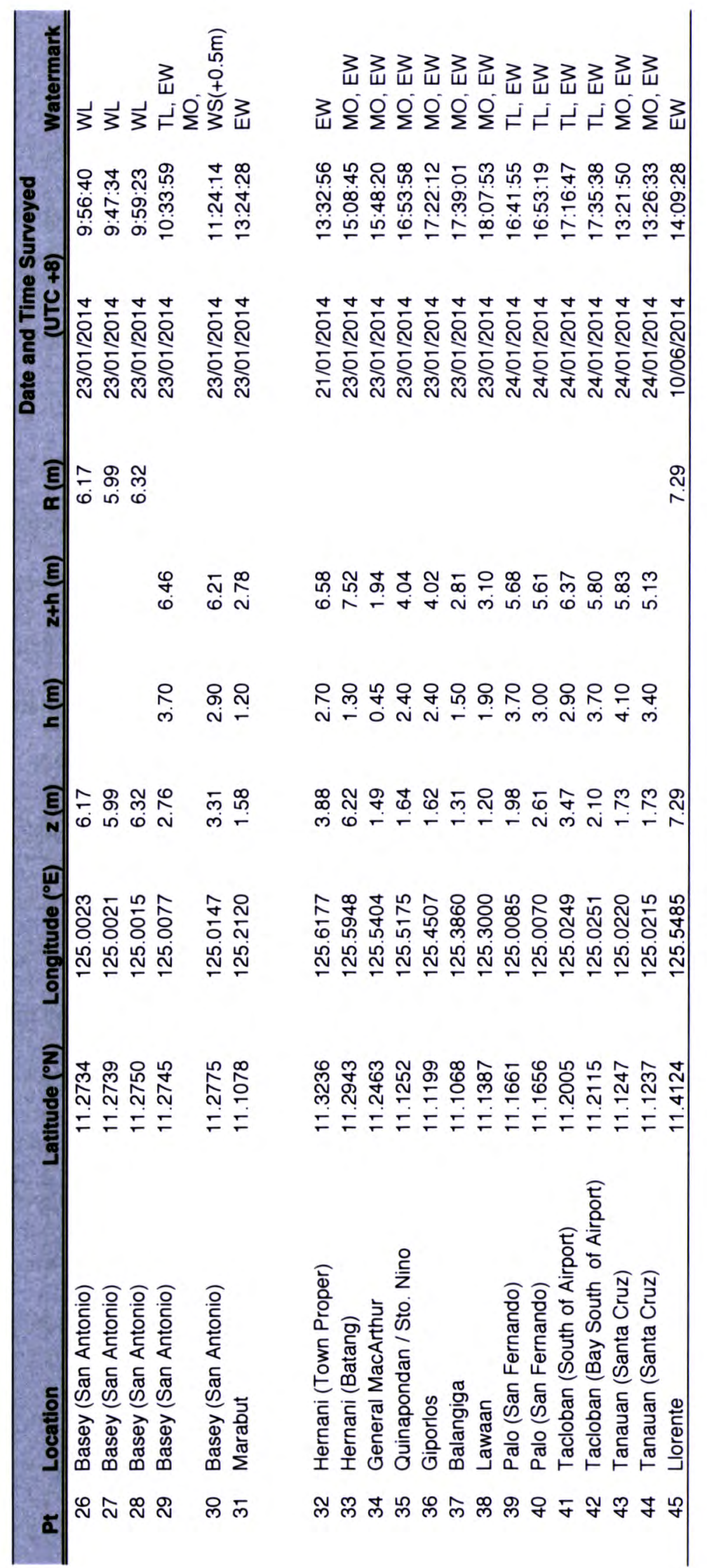




\subsubsection{Storm Surge Modeling of Typhoon Haiyan}

The Typhoon Haiyan storm surge in Leyte Gulf and San Pedro Bay was simulated using the open-source Delft3D Flow (Lesser et al. 2004) with a Matlab-based graphical user interface called Dashboard ${ }^{1}$. A curvilinear grid is used with a minimum resolution of $200 \mathrm{~m}$ and a maximum resolution of $1.2 \mathrm{~km}$. The domain encompasses the whole Leyte Gulf and extends into the San Juanico Strait to the north (Fig. 2.3a). The bathymetry of the model domain was acquired from digitized navigational charts (National Mapping and Resource Information Authority, 1980). The maximum depths are found near the Leyte Gulf mouth, and the embayment shallows northward towards the San Juanico Strait (Fig. 3B). Open-boundary conditions are astronomic tides using 8 dominant constituents $\left(\mathrm{M}_{2}, \mathrm{~S}_{2}, \mathrm{~N}_{2}, \mathrm{~K}_{2}, \mathrm{~K}_{1}, \mathrm{O}_{1}, \mathrm{P}_{1}\right.$, and $\left.\mathrm{Q}_{1}\right)$ extracted and interpolated from the TOPEX 7.2 Global tidal model (Egbert and Erofeeva 2002) using the Dashboard tide database toolbox. The tidal pattern in San Juanico Strait interacting with the Samar Sea differs from the tidal pattern at Guiuan Station driven by the Philippine Sea (Fig. 2.3c). The complex tidal interaction highlights the need for accurate bathymetry of Leyte Gulf and San Juanico Strait to properly simulate the tides in Tacloban.

Typhoon wind fields for the modeling were generated from the typhoon track data of the JTWC. We recognize a $\sim 6 \mathrm{~km}$ offset between the JTWC typhoon track from the Doppler radar-derived track from PAGASA (Fig. 2.1 inset), but JTWC provides more

\footnotetext{
${ }^{1}$ http://publicwiki.deltares.nl/display/OET/DelftDashboard
} 

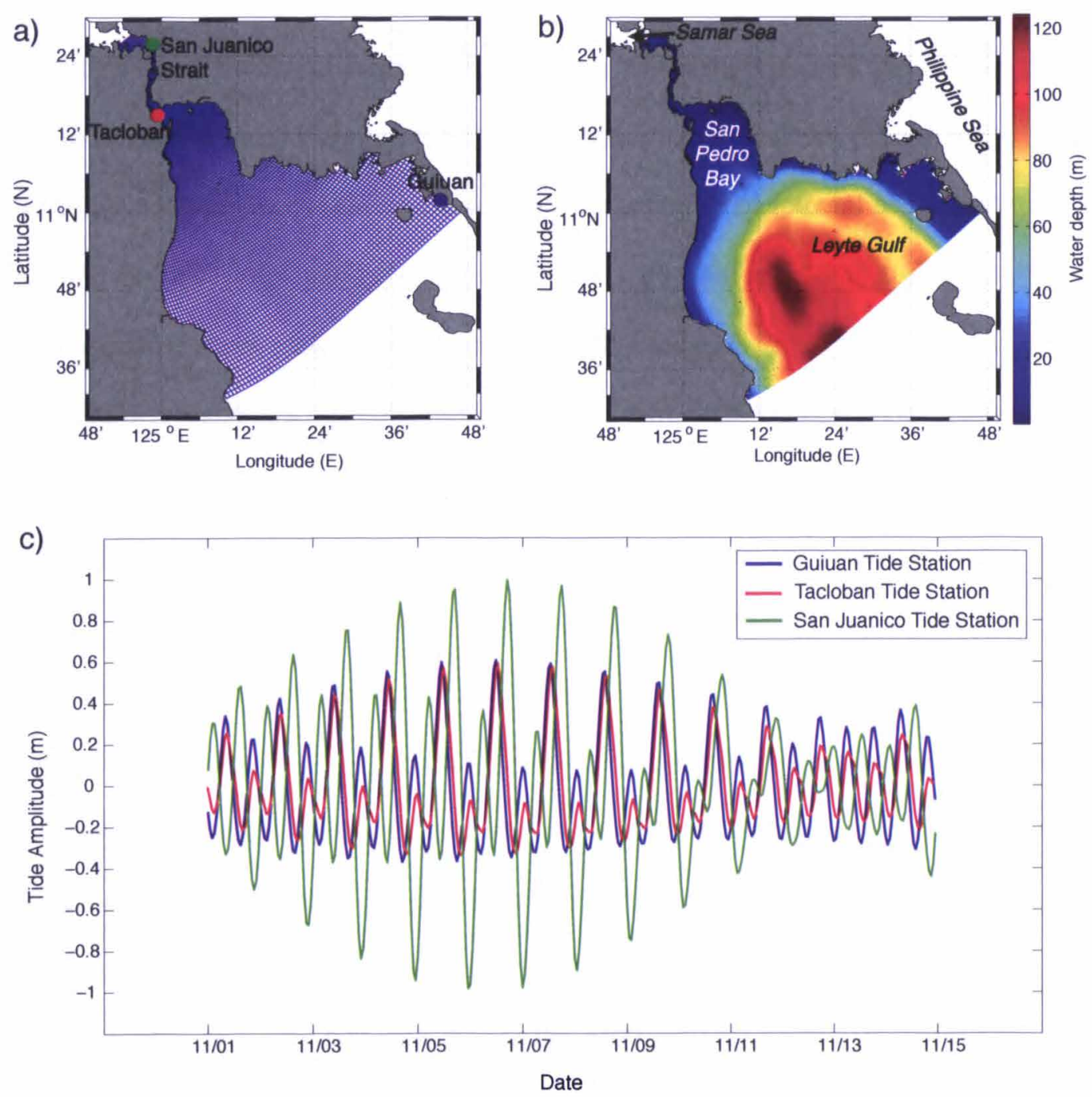

Figure 2.3. Geographical coverage, bathymetry, and tidal conditions of Leyte Gulf used in the model.

a) The model domain is a curvilinear grid with $200 \mathrm{~m}-1.2 \mathrm{~km}$ resolution.

b) Leyte Gulf bathymetry generated from digitized navigational charts with $100 \mathrm{~m}-1 \mathrm{~km}$ resolution.

c) Predicted water levels from San Juanico Strait, Tacloban City and Guiuan, Samar. 
continuous along-track wind data, required in the model. The model wind files were generated by the Delft Dashboard tropical cyclone toolbox using the model by Holland (1980) and interpolated onto the computational grid. The model was initialized by wind and tide conditions at 0000 on 5 November 2013 UTC and allowed to run until 2400 on 11 November 2013 UTC. Sea level and current outputs were saved at 1-minute intervals between 1900 on 7 November UTC and 0600 on 8 November UTC. An earlier model of Bricker et al. (2014) used the same Delft3D software with JMA wind data forcing and a Quiring's relationship of maximum wind radius. Their model yielded a maximum water level of less than $6 \mathrm{~m}$ in Tacloban.

\subsubsection{Storm surge modeling of Ty 1897}

To model the likely storm surge generated by Ty 1897 , we used the same grid and boundary forcing conditions of Typhoon Haiyan, but with tides simulated from 10 to 12 October 1897. Algué (1898) reported pressures and winds recorded in various parts of the Philippines during Ty 1897 , but the Dashboard typhoon module requires alongtrack minimum central pressures and maximum winds. This requirement limited us to use only the data recorded in areas directly hit by the eye of Ty 1897 , the in-situ barometric pressures measured at Guiuan and Tanauan. Apart from these two locations, no instrumental record on the typhoon eye exists. The minimum pressures before landfall in Guiuan and after landfall in Tanauan were estimated considering the values for Ty 1897 and Typhoon Haiyan. Barometric records in Guiuan and Tanauan indicate a less intense Ty 1897 at landfall than Typhoon Haiyan. To account for the weaker 
intensity of Ty 1897 , we took the pressure difference between Typhoon Haiyan and Ty 1897 in Guiuan and in Tanauan, and the delta values were then subtracted from the Typhoon Haiyan pressure values.

Given the barometric records of Ty 1897 in Guiuan and Tanauan, a range of wind speed values were derived from empirical wind-pressure relationships using the stormmapping table summarized by Nakazawa and Hoshino (2009) for the western North Pacific region (Table 2.2). Our model, however, used the wind speed corresponding to Atkinson and Holliday (1977), which is the most direct method among the windpressure relationships considering the limited instrumental data on Ty 1897. Knaff and Zehr (2007) emphasized the uncertainties inherent in the regression method of Atkinson and Holliday (1977) in estimating wind speeds of tropical cyclones over the northwest Pacific. Despite the reliability concerns, the maximum wind speed estimates for Ty 1897 using Atkinson and Holliday (1977) still yielded values similar or within the range of the mean standard error $(6-9 \mathrm{kt})$ of other established robust wind-pressure relationships.

\subsection{Typhoon 1897 versus Typhoon Haiyan}

\subsubsection{Typhoon track and forward speed}

The reconstructed track of Ty 1897 (Figs. 2.1 \& 2.2) was adopted from Algué (1898) based on the synthesis report containing maps and compilation of barometric curves. Instrumental records for the historical Ty 1897 came from modified aneroid barometers 
established by Jesuit priests on land (at churches) and at sea (on ships) in different locations of the Philippine archipelago. The observed pressure, wind direction, and temperature were used to establish the distance and direction of the vortex (eye) of the typhoon from the observer (Algué 1904; Udías 1996). Algué's map was georeferenced to a regional map derived from a $90 \mathrm{~m}$ x $90 \mathrm{~m}$ resolution satellite radar image, and then the typhoon track was digitized. Given the different resolution of Algué's map and the regional map, we expect that the digitized track has uncertainties of $\sim 1 \mathrm{~km}$ in the N-S direction, and $\sim 2 \mathrm{~km}$ in the $\mathrm{E}-\mathrm{W}$ direction.

Table 2.2. Minimum barometric pressure of Ty 1897 recorded in Guiuan and Tanuan and the corresponding Current Intensity (CI)-number and maximum wind speeds.

\begin{tabular}{|c|c|c|c|}
\hline Parameters/Location & Guiluan & Tanauan (Initial) & $\begin{array}{l}\text { Tanauan } \\
\text { (Corrected) }\end{array}$ \\
\hline \multirow[t]{2}{*}{ Date and Time } & 12 Oct 1897 & 12 Oct 1897 & 12 Oct 1897 \\
\hline & 08:45am & 11:10am & 11:10am \\
\hline Minimum central pressure, $\mathrm{mm}$ & 710 & 704 & 694 \\
\hline Minimum central pressure, $\mathrm{hPa}$ & 947 & 938 & 925 \\
\hline Observed wind condition & Relative calm* & Absolute calm & Absolute calm \\
\hline $\begin{array}{l}\text { 1-min Maximum sustained winds, kt } \\
\text { (kph) Atkinson and Holliday, } 1977\end{array}$ & $96(179)$ & $105(194)$ & $115(212)$ \\
\hline Cl (Dvorak, 1975) & 6 & 6.5 & 7 \\
\hline Cl (Dvorak, 1984) & 5.5 & 6 & 6 \\
\hline $\begin{array}{l}\text { 1-min Maximum sustained winds, kt } \\
\text { (kph) Dvorak }\end{array}$ & $102(189)$ & $115(213)$ & $115(213)$ \\
\hline $\mathrm{Cl}(\mathrm{Koba}, 1990)$ & 5.5 & 6 & 6.5 \\
\hline $\begin{array}{l}\text { 10-min Maximum sustained winds, kt } \\
\text { (kph) Koba, } 1990\end{array}$ & $85(157)$ & $93(172)$ & $100(185)$ \\
\hline
\end{tabular}

* The relatively calm wind condition recorded in Guiuan indicates that the eye has passed close but not directly over the recording site. As such the Guiuan dataset should be considered as a near minimum value. 
Upon evaluating the pressure and wind observations, Algué (1898) estimated the landfall timing and the forward speed of Ty 1897 between Guiuan and Tanauan. Ty 1897 made its initial landfall $\sim 10 \mathrm{~km}$ south of Guiuan shortly after 0800 on 12 October 1897 PHT (0000 UTC 12 October). At landfall, the barometer in Guiuan registered the lowest pressure at $710 \mathrm{~mm}(947 \mathrm{hPa})$, simultaneous with the observed relatively calm winds. The relatively calm wind condition indicates an eye passage in close proximity but not directly over the recording site. As such, the Guiuan dataset should be considered only as a near minimum value. The typhoon continued westwards almost following along the northern coastline of Leyte Gulf. At about 1100 on 12 October 1897 PHT (0300 UTC 12 October) the eye of the typhoon was about $21 \mathrm{~km} \mathrm{NNE}$ of Dulag, and $13 \mathrm{~km}$ SSE of Tacloban, before it made a second landfall in Tanuan shortly after 1100 PHT. At landfall, the barometer in Tanauan registered the lowest pressure of $704 \mathrm{~mm}$ equivalent to $938 \mathrm{hPa}$, but after further analysis was lowered to $694 \mathrm{~mm}$ equivalent to $925 \mathrm{hPa}$ (Algué 1898; Algué 1904). Simultaneous with the lowest pressure was an absolute calm wind lasting for about 40 minutes. To the north, the adjacent town of Palo also experienced the zone of absolute calm but only for 10 minutes. The longer duration of absolute calm in Tanauan compared to Palo suggests that Tanauan was located closer to the center of the typhoon's eye. In a span of 2.5 hours, Ty 1897 traversed about 43 geographical miles $(\sim 80 \mathrm{~km})$ between Guiuan and Tanuan, equivalent to a forward speed of about $17 \mathrm{mi} \mathrm{h}^{-1}$ or $28 \mathrm{~km} \mathrm{~h}^{-1}$ (Algué 1898, p. 66). According to Algué's map, Ty 1897 made subsequent landfalls on three islands across the central Philippines before it exited into the South China Sea. 
The Jesuits ground-based method of instrumental recording and monitoring of typhoons to establish the track and intensity prevailed for many decades (Udías 1996) until it was replaced by reconnaissance aircraft, radar, and satellite observations towards the mid $20^{\text {th }}$ century (Emanuel 2005a; Velden et al 2006). Today, weather services combine instrumental recordings with satellite-based observations of the cloud patterns in visible and infrared satellite images to establish a central location of a typhoon and to estimate typhoon intensities. At the forefront of this satellite-based method of tropical cyclone intensity was Dvorak (Dvorak 1975). The Dvorak method originally developed for Atlantic conditions has been adopted and applied to other ocean basins that have different atmospheric conditions like the Pacific (e.g. Velden et al 2006; Knaff and Zehr 2007; Lander et al. 2014). Unfortunately, there is no unified operational method among weather agencies for tracking and assigning typhoon intensities, as such, the reported track and intensity of one storm are commonly variable. This was the case with Typhoon Haiyan, where the tracks across Leyte Gulf released by JMA and JTWC are consistently offset $\sim 6 \mathrm{~km}$ to the south of the PAGASA Doppler radar-based track. The PAGASA track, however, appears more consistent with the local field observation and ground truthing (Morgerman 2014). We note that based on the PAGASA typhoon track, Typhoon Haiyan moved from Guiuan westwards to Tolosa at about $43 \mathrm{~km} \mathrm{~h}-1$ or about 1.5 times faster than Ty 1897. 


\subsubsection{Typhoon intensity and size}

The wide range of instrumental recording through history and the variety of operational wind-pressure relationships among meteorological agencies make typhoon intensity classification based on the maximum wind speed inherently uncertain (Knaff and Zehr 2007; Nakazawa and Hoshino 2009). To address the issues arising from the wind speed-derived typhoon intensity, Knapp and Kruk (2010) and Kruk et al. (2011) proposed the use of Current Intensity (CI) in comparing typhoons particularly in establishing trends of tropical typhoon intensities. Kruk et al. (2011) recognized that due to imagery interpretation of contemporary typhoons, satellite-derived intensity Tnumber when converted to $\mathrm{CI}$ could result in intensity differences of 0.5 on the CI scale. Meanwhile, the primary sources of uncertainty for the pressure-derived intensity of historical typhoons such as the Ty 1897 arise from the sparse recordings and possible instrumental errors. The historic correction of $\sim 13 \mathrm{hPa}$ applied to the minimum pressure of Ty 1897 on the Tanauan barometer record may give some indication of the magnitude of instrumental errors. For intense typhoons like Ty 1897 , the historic correction corresponds to a difference of 0.5 on the CI scale, which is of similar magnitude as the uncertainty of satellite-derived CI. Hence, the corresponding CI numbers for Ty 1897 and Typhoon Haiyan may provide a reasonable metric to compare the intensity between these two typhoons.

As discussed previously, the observed lowest pressure and absolute calm wind of Ty 1897 consistently indicate that the typhoon eye passed directly over Tanauan. Taking 
the minimum pressure of $925 \mathrm{hPa}$ as the closest approximation of the central minimum pressure, Ty 1897 was assigned an equivalent $\mathrm{CI}$ number of 6 to 7 upon landfall. For Typhoon Haiyan, ground instruments only recorded near-minimum pressures. The Doppler radar in Guiuan registered a mean sea-level pressure of $\sim 940 \mathrm{hPa}$ before it was totally destroyed at the peak intensity of the typhoon (IRIDeS 2014). Independent measurements of PAGASA and Morgerman (2014) indicate a lowest pressure at 960 $\mathrm{hPa}$ in Tacloban City, which was located on the northern eyewall of the typhoon, 24 km away from Typhoon Haiyan's center. In contrast, using the satellite-based Dvorak technique Typhoon Haiyan has a signature Typhoon Number of T8.0 (Lander et al. 2014), which corresponds to a CI number of 8 , the highest on the scale. As such, the CI 8 Typhoon Haiyan was more intense than the CI 6 to 7 of Ty 1897 .

Not only that Typhoon Haiyan was more intense, it was also larger than Ty 1897 based on the eyewall size. Morgerman (2014) corroborated the eye of Typhoon Haiyan based on wind observations of eyewitnesses and a radar image, indicating a $13 \mathrm{~km}$ radius of the eyewall. In contrast, the Jesuit approach based on the zones of absolute and relative calm winds as indicators of the relative location of the typhoon eye results in eyewall radius of $6 \mathrm{~km}$ to $10 \mathrm{~km}$ for Ty 1897 .

Given the contrasting operational methods between 1897 and 2013, it remains difficult to directly compare Typhoon Haiyan and Ty 1897 with absolute certainty. The available meteorological parameters, however, suggest that Typhoon Haiyan and Ty 
1897 were nearly identical based on the trajectory, while characteristic differences prevailed concerning other aspects. Typhoon Haiyan followed a parallel track direction with a $\sim 6 \mathrm{~km}$ offset to the south of Ty 1897 . Typhoon Haiyan was more intense, had wider eyewall coverage, and was moving faster than Ty 1897 . The possible effects of the slight variations in track, minimum central pressure, estimated maximum winds, and forward movement between the two typhoons on the storm surge characteristics will be explored in the following sections.

\subsection{Typhoon 1897 and Typhoon Haiyan storm surges}

\subsubsection{Post-typhoon field measurements}

The Ty 1897 storm surge measurements of Algué (1898) were based on eyewitness accounts (Fig. 2.2). These field measurements indicate inundation heights exceeding 4 $\mathrm{m}$ in most places with a maximum height of over $7 \mathrm{~m}$ on the open-sea coast at Hernani (Fig. 2.2c). Along San Pedro Bay in Basey (Fig. 2.2b), the water gradually rose and reached a maximum level of $4.9 \mathrm{~m}$. The peak flooding corresponded with the most violent winds from the southeast. In the nearby coast of Tacloban (Fig. 2.2a), water rose between $3.9 \mathrm{~m}$ and $4.6 \mathrm{~m}$. The peak flooding coincided with the winds blowing from the east to east-southeast, directly perpendicular to the Tacloban coast. In close proximity to the eye of Ty 1897 at Tanauan and Tolosa (Fig. 2.2a), the water rose to 3 m.

Algué's "Ola del Huracán" or hurricane wave was the elevation of the sea, with the 
surface forming like a warp pyramid whose peak approximately corresponds to the vortex (eye) of the typhoon, analogous to the water surface being sucked by a vacuum pump (Algué 1898, p. 9). Moving with the typhoon, this huge wave when launched against the shore makes the water rise to an extraordinary height, causing severe flooding, and extensive destruction (Algué 1898, p. 10). We interpret this description as equivalent to what we now call "storm surge". Algué overestimated the contribution of the pressure drop over the wind field as the primary contributor to the significant rise of the sea surface, because of the different locations of the eye and the areas where water elevations were highest. The sea rose to about $3 \mathrm{~m}$ in Guiuan and Tanauan, but the rise was highest at Hernani, Basey, and Tacloban on the typhoon's strong side to the north of the typhoon eye. The peak flooding during Ty 1897 at each of these sites consistently coincided with winds blowing directly perpendicular towards the coastline. Contrary to Algué's attribution of the surge solely to the low central pressure, the wind field was the primary driver of the storm surge (Emanuel 2005b).

The measured high water marks after Typhoon Haiyan (Fig. 2.2) were separately classified into maximum surge heights and surge plus storm waves. For a wider and denser spatial coverage, we combined our field measurements with the survey of Tajima et al. (2014). In both surveys, each high-water mark indicator was referenced to the reconstructed tide level at the time of peak flooding. Heights differed by as much as $1 \mathrm{~m}$ at slightly different locations. Discrepancies of up to $2 \mathrm{~m}$ at corresponding locations were attributed to short-period storm waves superimposed on top of the surge. 
High-water marks with significant storm-wave contributions were carefully identified based on eyewitness accounts, the type of physical watermark and the inland location. Surge height measurements from different high water mark indicators in both surveys were mostly consistent.

At Tacloban located some $23 \mathrm{~km}$ to the north of Haiyan's track (Fig. 2.2a), the characteristic height of the storm surge peak was $7 \mathrm{~m}$. Wave contributions raised highwater marks up to almost $8 \mathrm{~m}$ in Tacloban and Palo. On the more open and exposed Pacific coastline at Hernani (Fig. 2.2c), some $45 \mathrm{~km}$ north of the typhoon track, significant storm-wave contributions resulted in high water marks exceeding $7 \mathrm{~m}$. Further amplification by the wave runup on steep slopes such as near Guiuan resulted in a maximum runup height of $14 \mathrm{~m}$ (Tajima et al. 2014). Surge heights exceeding $5 \mathrm{~m}$ were recorded along the shores of San Pedro Bay. We detail the nature of the storm surge in San Pedro Bay, where the highest death toll was recorded, in the next section. Outside of San Pedro Bay, but still within Leyte Gulf, the surge heights were only 3 to $4 \mathrm{~m}$ between Marabut and Quinapondan (Fig. 2.2b) because the storm track was parallel to the coastline. Water marks as high as $5 \mathrm{~m}$ were attributed to storm-wave contributions. In close proximity to Haiyan's landfall location between Tolosa and Dulag, the surge heights ranged between 3 and $5 \mathrm{~m}$ (Fig. 2.2a). At an exceptional site in Dulag a $7 \mathrm{~m}$ high-water mark was compromised by significant storm-wave contribution. The lowest surge height of about $2 \mathrm{~m}$ was recorded at General MacArthur on the eastern coast of Samar (Fig. 2.2c). The site is sheltered behind fringing coral 
reefs located $3 \mathrm{~km}$ offshore, and is on a bay with a narrow bottleneck entrance attenuating storm waves, and resulting in a measurement dominated by the storm-surge component.

\subsubsection{Storm surge simulations of Typhoon Haiyan and Ty 1897 in San Pedro Bay}

The Haiyan storm surge modeling results resolved an initial sea level drawdown around 2130 on 7 November 2013 UTC (0530 PHT 8 November) in accordance with eyewitness accounts and the Tacloban tide gauge recording (Fig. 2.4). The tide gauge recorded a drawdown of at least $0.8 \mathrm{~m}$ before it broke down ${ }^{2}$, while modeling suggests a drawdown of at least $1.2 \mathrm{~m}$ at the head of San Pedro Bay (Fig. 2.4 a \& b). The initial sea-level drawdown was also observed at Basey on Samar (Amadore 2013). The drawdown was generated by persistent strong, northerly offshore winds that initially drove the waters southwards out of San Pedro Bay (Fig. 2.4 a \& b). Similar sea-level drawdowns or negative surges from strong offshore winds during historic hurricanes have also been reported for the western Florida coasts (Harris 1963; Lawrence and Cobb 2005). The drawdown exposed the sea floor and dramatically steepened the storm tide profile. This phenomenon is analogous to negative leading $\mathrm{N}$-wave during tsunamis, usually resulting in a higher runup (Tadepalli and Synolakis 1994). Eyewitness accounts and modeling show that the storm tide arrived as an unusually fast-moving 'tsunami like' wave front, which caused high velocity coastal flooding to heights of more than $7 \mathrm{~m}$ near Tacloban and Basey. Residents in Basey, who stayed in

2 The Tacloban tide data was provided by the National Mapping and Resources Information Agency (NAMRIA) of the Republic of the Philippines. 

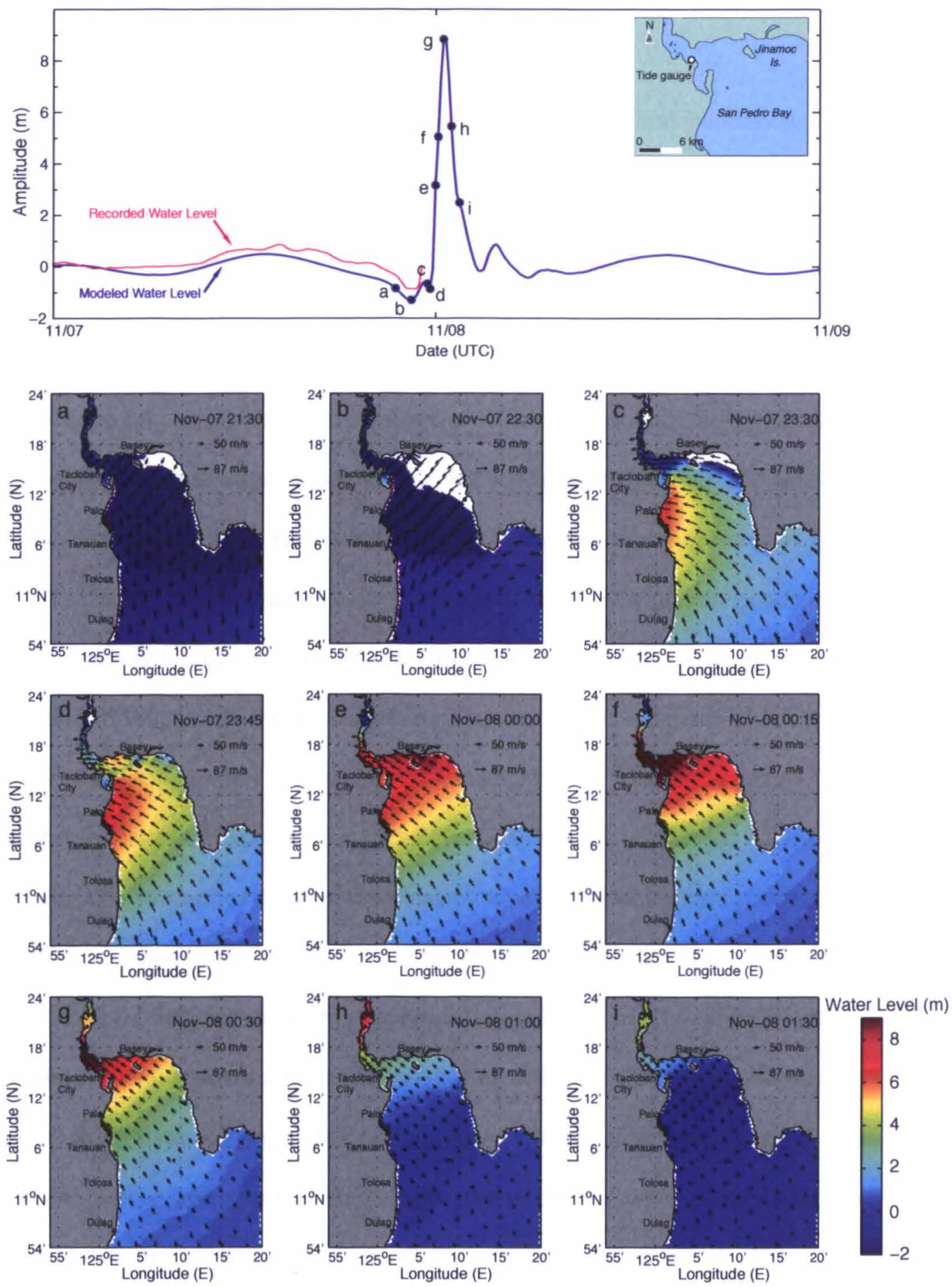

Figure 2.4. Sea-level heights in Tacloban and nearby coasts around San Pedro Bay during Typhoon Haiyan. (top) Graphical representation of the water levels from storm surge model (blue line) and from Tacloban Port tide gauge (red line). Both the actual and modeled tides show receding sea level prior to the peak surge.

a-i: Storm surge model sequence of Typhoon Haiyan in San Pedro Bay from 2130 on 7 November to 0130 on 8 November 2013 UTC with colors and arrows representing water level and wind magnitude and direction, respectively. 
their homes despite prior evacuation warnings, described a large wave similar to a tsunami striking soon after the water receded, providing only a few minutes of lead time to seek refuge at higher elevations.

The initial rise, peak, and lowering of flood levels due to the storm surge varied considerably in time and location. In downtown Tacloban, the peak surge occurred around 0000 UTC 8 November ( 0800 PHT 8 November) according to videos recorded by several eyewitnesses and the detailed coverage by storm chaser Morgerman (2014). The inundation timing was further confirmed by two wall clocks located about $14 \mathrm{~km}$ apart along the western shores of San Pedro Bay, which were stopped as seawater floods reached about 1.5 to $2 \mathrm{~m}$ high. In Tanauan, the clock stopped at 0720 PHT (2320 UTC 7 November); the clock in Tacloban City stopped few minutes later, at 0730 PHT (2330 UTC 7 November). The timing from the videos and wall clocks are consistent with the storm surge model. The modeled timing of the peak surge coincided with the timing of the onshore-directed winds closely linked to the forward motion of Typhoon Haiyan (Fig. $2.4 \mathrm{c}-\mathrm{g}$ ). The modeled peak surge of 6 to $8 \mathrm{~m}$ in San Pedro Bay occurred between 0000 and 0030 UTC ( 0800 and 0830 PHT) on 8 November, arrived earlier along the eastern shores at the entrance of the bay, and propagated northwards to the bay head. It is likely that several eyewitnesses in Dulag observed the front of the storm surge. During the passage of the eye (calm winds), eyewitnesses saw an offshore 'wall of water' about $6 \mathrm{~m}$ high that first was mowing west towards Dulag but then suddenly redirected north towards Tacloban. The peak surge lasted for at least 30 minutes, and 
then just before 0100 UTC (0900 PHT) on 8 November, the water subsided (Fig. 2.4 hi).

In addition, the modeled water level in Figure 2.4 shows three apparent peaks corresponding to points $\mathrm{C}, \mathrm{G}$, and after point $\mathrm{I}$. The peaks may coincide with the three "waves" reported by eyewitnesses (Amadore 2013; Morgerman 2014), although the timing could not be verified since the eyewitnesses did not track the timing of the three waves. In the open sea coast of Hernani, accounts of the storm surge coming in three waves also exist. The video footage from Hernani showed the building collapsing with the impact of the second wave, which corresponds to the highest and steepest peak in the storm surge model in San Pedro Bay.

The storm-surge simulation of Ty 1897 (Fig. 2.5) showed water levels and peak surge timing that are consistent with Algué's report (Supplemental Material). In Basey, northerly-northeasterly offshore winds forced the water to recede (Fig. 2.5a). The initial rise of the surge occurred with the easterly-southeasterly winds (Fig. 2.5b) whereas; south-southeasterly winds caused the peak surge in Tacloban and Basey (Fig. 2.5 c-d). On the contrary, in Tolosa the model did not absolutely replicate the actual surge height. Algué reported surge height of $\sim 3 \mathrm{~m}$, but the model yielded $2 \mathrm{~m}$. The discrepancy can be attributed to various factors including changes in near-shore bathymetry, storm-wave contribution, and uncertainties in the Ty 1897 typhoon parameters. For the most part of San Pedro Bay, the modeled surges indicate that Ty 

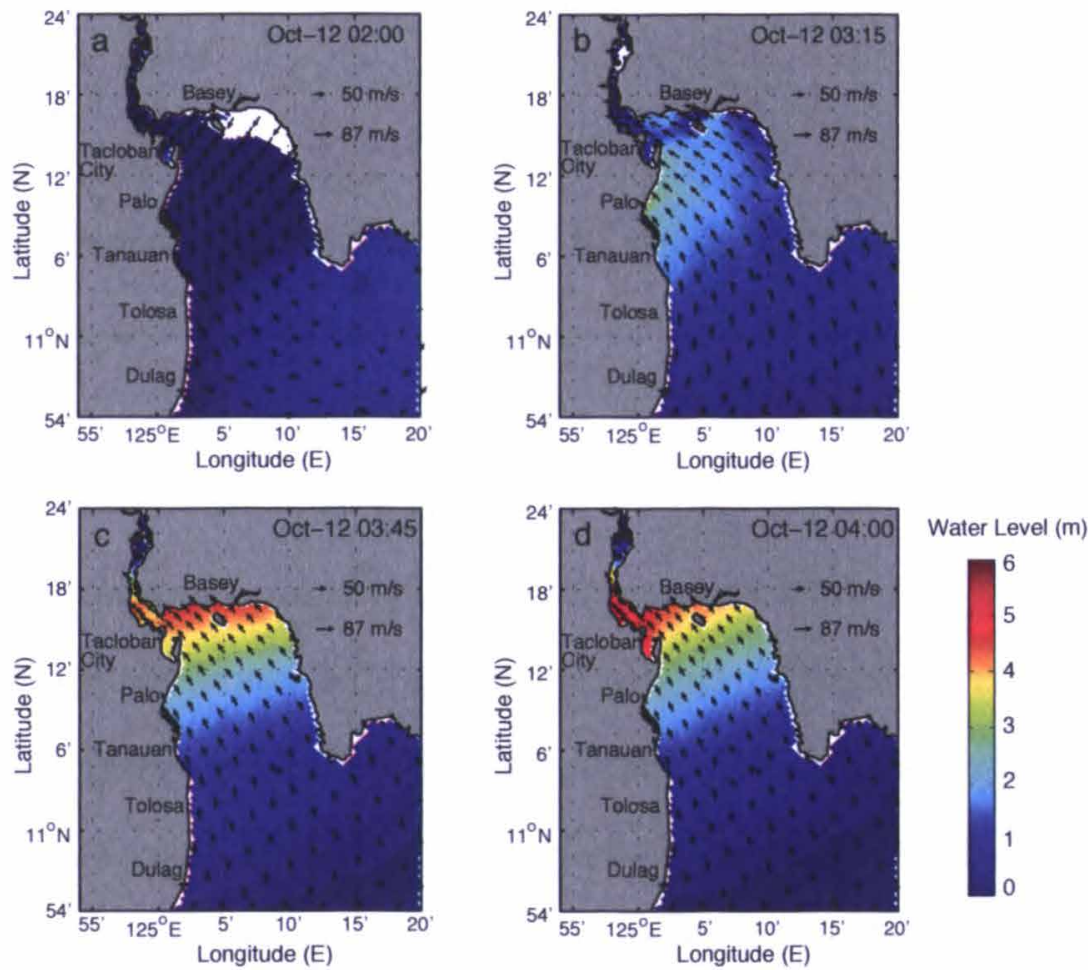

Figure 2.5. Storm surge model sequence of Ty 1897 in San Pedro Bay from 0200 to 0400 on 12 October 1897 UTC with colors and arrows representing water level and wind magnitude and direction, respectively.

a)

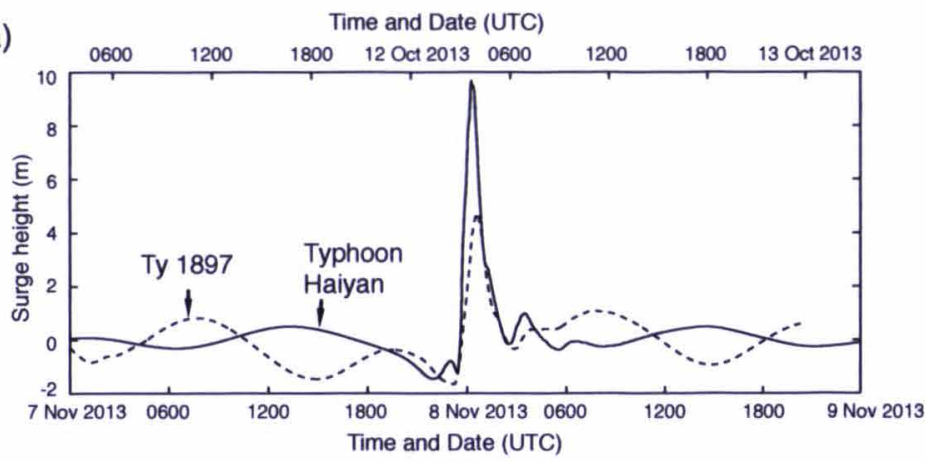

b)

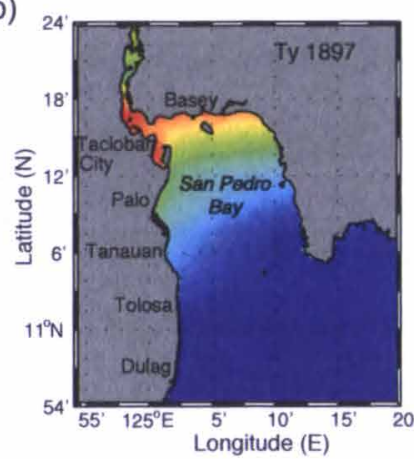

c)

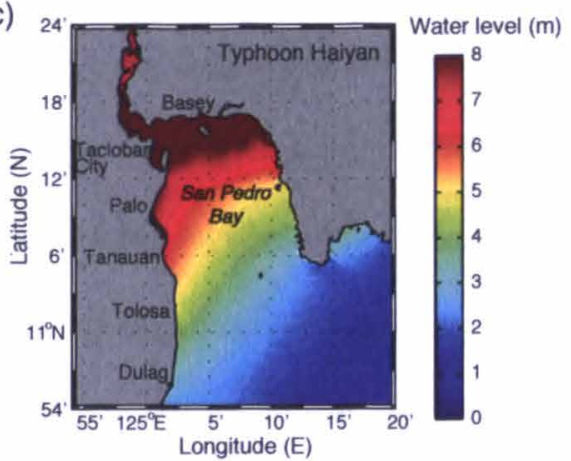

Figure 2.6. Modeled surge heights comparison between Ty 1897 and Typhoon Haiyan in San Pedro Bay.

a) Graphical representation of the modeled water level at Tacloban for Ty 1897 and Typhoon Haiyan.

b) Modeled maximum surge heights in San Pedro Bay during Ty 1897.

c) Modeled maximum surge heights in San Pedro Bay during Typhoon Haiyan. 
1897 generated lower surge heights than Typhoon Haiyan (Fig. 2.6), which is consistent with the field measurements for both storm surge events. The magnitude difference of the modeled surge heights between the two typhoons (Fig. 2.7) is also consistent with the magnitude difference of the measured water levels in both posttyphoon surveys.

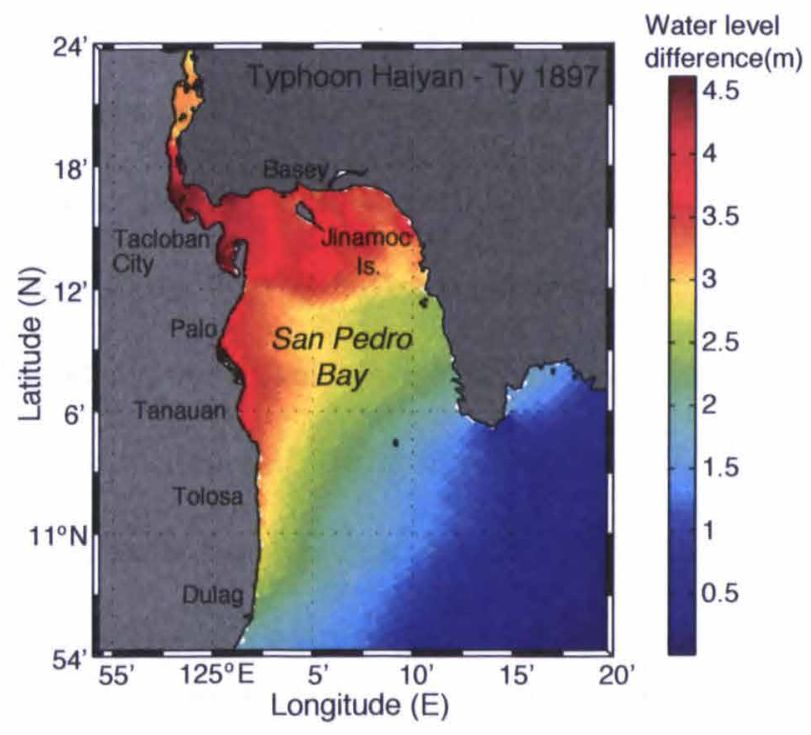

Figure 2.7. Difference in water levels of the modeled maximum surge height between Ty 1897 and Typhoon Haiyan in San Pedro Bay.

\subsection{Implications for disaster management}

\subsubsection{Understanding the local storm surge hazard}

The complex interactions among several factors including typhoon intensity represented by lowest pressure and maximum wind speed, forward movement of the typhoon, storm size, bathymetry, coastline shape, and tidal phase result in varying 
storm surge height and flooding duration for any storm (e.g. Emanuel 2005b; Irish et al. 2008; Needham and Keim 2014). Given the similar areas impacted by the storm surges of Ty 1897 and Typhoon Haiyan, the coastal geomorphology is assumed to be relatively constant for these two events. Lander et al. (2014) estimated a $20 \mathrm{~cm}$ sealevel rise between 1970 and 2013 , which likely did not contribute significantly to the impact of the storm surge from Typhoon Haiyan. The effect of sea-level rise on the tidal phases of Ty 1897 and Typhoon Haiyan is beyond the scope of this study. We focused on differences in typhoon characteristics including track, intensity, size, and forward movement and their possible effect on the storm surge characteristics.

Despite the atmospheric differences between the Ty 1897 and Typhoon Haiyan, the resulting two storm surges share notable similarities dictated by the local coastal configuration (Fig. 2.2). At exposed locations like Hernani, both typhoons generated peak surges exceeding $7 \mathrm{~m}$ with significant storm-wave contributions superimposed on top of the surge. In stark contrast, sheltered locations such as General MacArthur experienced the lowest flood levels with 2-m peak surges. Another similarity in both typhoons was the water receding off Basey in San Pedro Bay prior to the peak surge. Based on the historical accounts and our simulations, the $1.2 \mathrm{~km}$ wide strait separating Jinamoc Island from Basey can be exposed as the water recedes prior to the peak surge given the shallow water depth of $\sim 1.5 \mathrm{~m}$ under normal conditions. In both typhoons, the surge in San Pedro Bay initially rose just before the typhoon made landfall on Leyte Island with easterly onshore winds. The surge then peaked with the southeasterly onshore winds as the typhoon eye moved west towards the interior of Leyte Island 
(Figs. $2.4 \& 2.5$ ).

Irrespective of the coastal configuration, whether in exposed open-sea (e.g. Hernani) or in sheltered embayment (e.g. San Pedro Bay), the typhoon forward motion resulted in significantly different peak flooding duration between the two storm surge events. The slower forward motion of Ty 1897 resulted in longer peak floods lasting for about 3 hours. In contrast, the much faster moving Typhoon Haiyan resulted in rapid highvelocity peak floods spanning about 30 minutes to nearly one hour.

The higher and more extensive peak surge around San Pedro Bay during Typhoon Haiyan compared to Ty 1897 (Fig. 2.6) could be due to the latitudinal shift of the typhoon tracks, differences in the intensity and forward motion of these two typhoons, or a combination of these factors. The northerly track of Ty 1897 made Tanauan the landfall location reducing the surge near Palo and Tanauan; this is true especially given the relative absence of strong onshore winds when compared to Typhoon Haiyan. Meanwhile, the relatively more intense and larger Typhoon Haiyan generated stronger onshore winds on the northern and western shores of San Pedro Bay. The stronger onshore winds in turn induced surge heights almost twice those of Ty 1897 and extending over a wider region (Fig. 2.6).

Apart from typhoon intensity, the storm size was recognized as an additional important factor in generating high storm surges and extensive inundation during Hurricane Katrina (Irish et al. 2008). Given the geometry of San Pedro Bay, however, the storm 
size might not be an equally significant factor in generating high storm surges in the case of Typhoon Haiyan. The distance from the Typhoon Haiyan track to the head of San Pedro Bay is $\sim 40 \mathrm{~km}$, which is well within the zone of maximum winds. Although considering the more southerly track of Typhoon Haiyan, storm size likely contributed to the extreme surge heights along the more exposed coasts of Eastern Samar such as at Hernani.

\subsubsection{Multi-hazard evacuation strategies}

Figure 2.8 shows the damage from Typhoon Haiyan surrounding San Pedro Bay. In the northern part Tacloban including the downtown area, the landward limit of inundation during Typhoon Haiyan exceeded 500 m (Tajima et al. 2014). Along low-lying, swampy areas south of downtown Tacloban and similarly at Tanauan, inundation extended more than $2 \mathrm{~km}$ inland. Overland flooding reached over $2 \mathrm{~km}$, but the primary areas of damage were concentrated within $200 \mathrm{~m}$ of the coast, highlighting the destructive power of storm waves riding on top of the storm surge has a limited inland penetration (FEMA 2011). Very few structures withstood the energy of the storm surge and superimposed storm waves (Fig. $\mathbf{2 . 8 b}$, d, and f). In areas above the surge heights, extreme typhoon winds caused greater damage, destroying roofs and wide swaths of coconut trees (Fig. 2.8e). Therefore, the combined hazards from storm surge flooding, extreme winds and the prevailing vulnerabilities must be considered to develop appropriate evacuation strategies. 

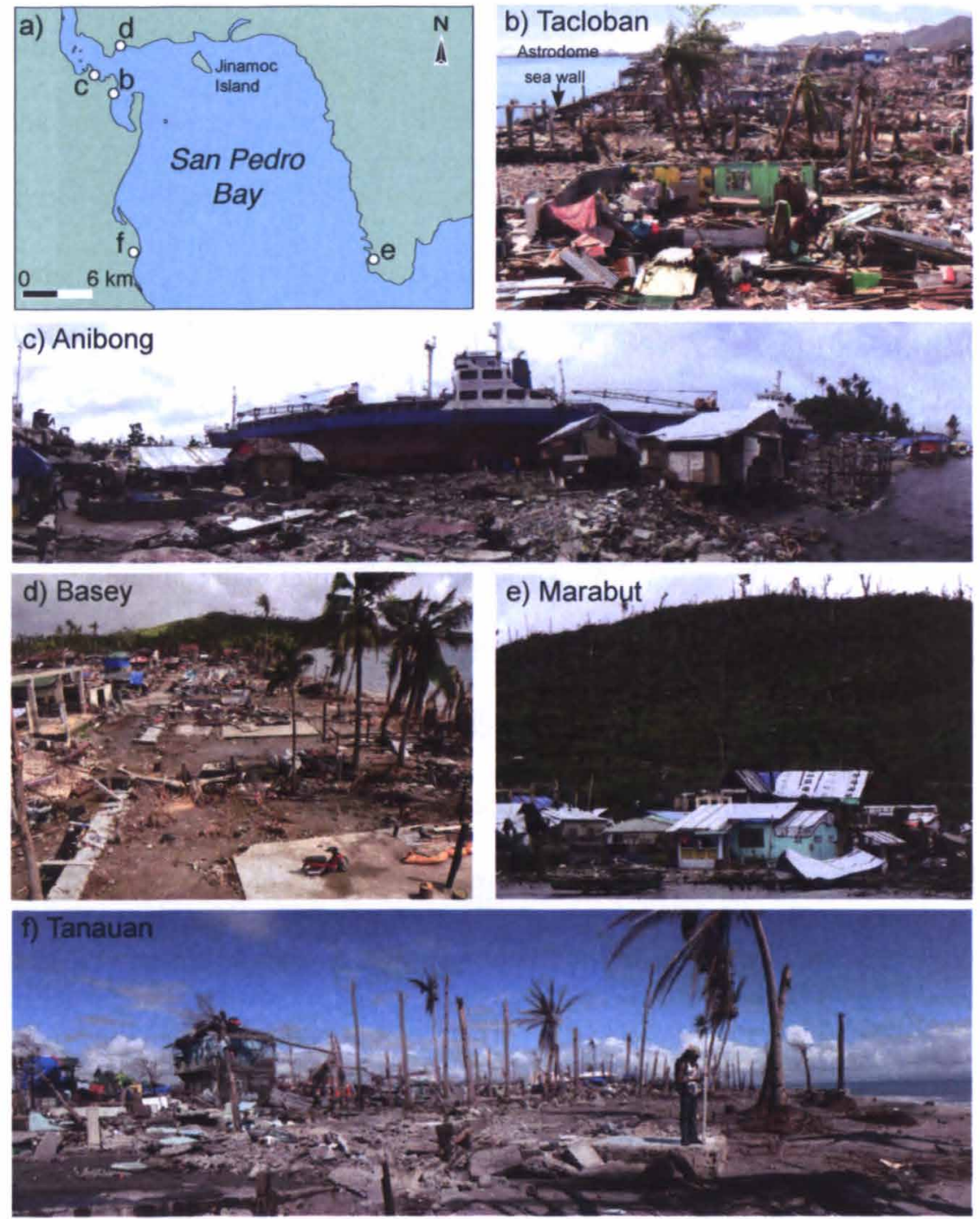

Figure 2.8. Photos of storm damage around San Pedro Bay.

a) Location map. Most structures proximal to the coast in Tacloban (b,c) Basey (d), and Tanauan (f) were completely destroyed by the storm surge and the overriding storm waves. Like in most coastal settlements existing guidelines on foreshore easement ${ }^{3}$ were completely ignored. (c) In Anibong village, just north of downtown Tacloban, stilt houses are rebuilt seaward of the stranded ships two months after the event. (e) In Marabut, wide swaths of palm trees chopped by the extreme winds.

\footnotetext{
${ }^{3}$ The Water Code of the Philippines (Presidential Decree 1067) states that designates an easement of $\mathbf{4 0}$ meters from seashore. This is supposed to be a "no build zone" area.
} 
2.6.3. Typhoon warning and response

The Philippine government issued typhoon forecasts and warnings for evacuations at least 18 hours before Typhoon Haiyan's landfall to achieve minimum and possibly zero casualties from the imminently approaching cyclonic storm threat (Ranada 2013;

NDRRMC 2013c; IRIDeS 2014). Preliminary social surveys suggest that local residents had a mixed response to the typhoon warnings emerging from complex social concerns (IRIDes 2014; Leelawat et al. 2014). These studies highlight that communication pathways, warning systems, evacuation plans, and multi-level hazard and disaster perception were significant concerns for evacuation decisions among individuals in the areas severely impacted by Typhoon Haiyan. These findings underscore the need for the authorities responsible for disseminating weather warnings to better understand how typhoon warnings are transmitted from an initial source through intermediate relays to the final recipients, as well as how the potentially vulnerable residents receive, heed, interpret, and decide to act upon these warnings. Given the historical perspective of storm surge hazards discussed in this paper, social scientists and historians may be able to improve local historical awareness about previous typhoon experiences, to aid in hazard perception and response. Historical records show that several storms with associated storm surges have affected the area between Ty 1897 and Typhoon Haiyan (Selga 1935, PAGASA 1998, Knapp et al. 2010; Fig. 2.9, Tables 2.3 \& 2.4). Among these storms, residents identify the November 1984 Typhoon Agnes and the associated coastal flooding ranging from 2 to $4 \mathrm{~m}$ in Samar and Leyte as the worst in memory (e.g. PAGASA 1998; Amadore 2013). 


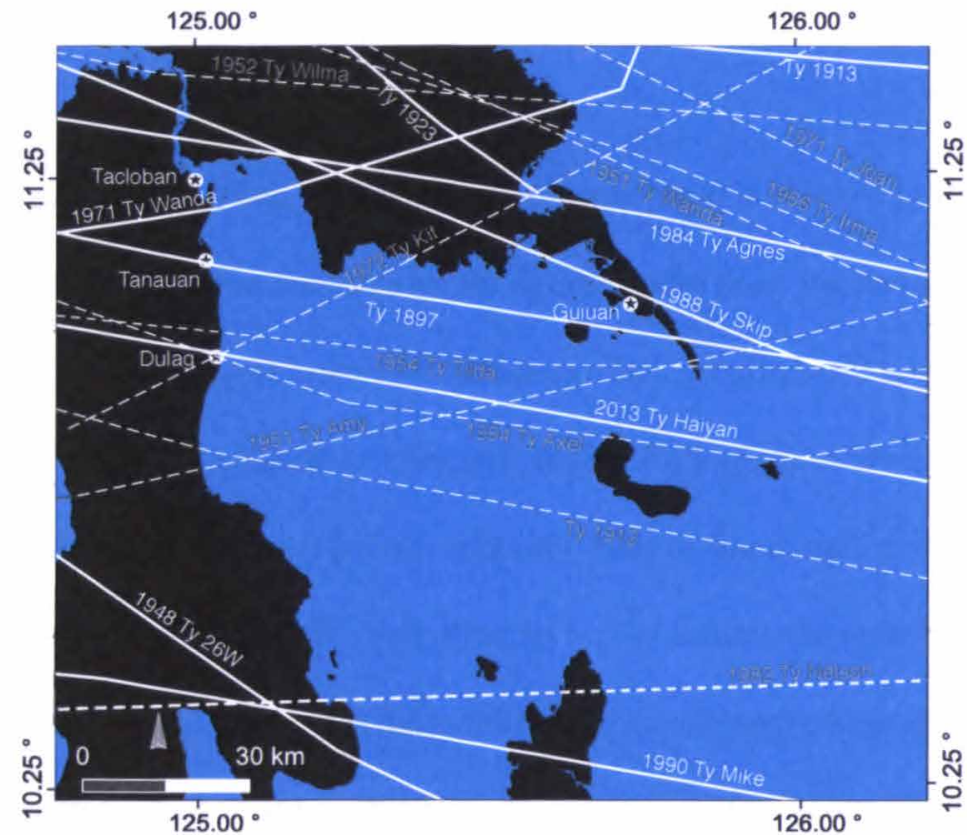

Figure 2.9. Landfalling tropical cyclones in the surrounding area of Leyte Gulf between 1897 and 2013. Storm tracks were from the IBTrACS database of Knapp and others (2010). The attributes of each typhoon are summarized in Table 2.3 and 2.4.

Table 2.3. Tropical cyclones with known storm surge occurrence (PAGASA 2000) (Represented in white solid lines)

\begin{tabular}{rllcc} 
No. & Name & Date & Max Winds, kts & Minimum Presure, hPa \\
\hline 1 & No Name & 12 Oct 1897 & & $\left(694 \mathrm{~mm}^{\mathrm{b}, \mathrm{c}}\right) 925$ \\
2 & No Name & 4 May 1913 & & $\left(727.8 \mathrm{~mm}^{\mathrm{c}}\right) 970$ \\
3 & No Name & 3 June 1923 & & $\left(739.52 \mathrm{~mm}^{\mathrm{c}}\right) 973$ \\
4 & 26W & 14 Dec 1948 & $35^{\text {a,JTWC }}$ & \\
5 & Wanda & 23 Apr 1971 & $40^{\text {a,JMA }}$ & $993^{\text {a,JMA }}$ \\
6 & Agnes & 04 Nov 1984 & $100^{\text {a,JMA }}$ & $925^{\text {a.JMA }}$ \\
7 & Skip & 07 Nov 1988 & $70^{\text {a,JMA }}$ & $955^{\text {a,JMA }}$ \\
8 & Mike & 12 Nov 1990 & $90^{\text {a,JMA }}$ & $935^{\text {a,JMA }}$ \\
9 & Haiyan & 08 Nov 2013 & $125^{\text {a,JMA }}$ & $895^{\text {a,JMA }}$ \\
\hline
\end{tabular}

Table 2.4. Tropical cyclones with unknown storm surge occurrence (Represented in white dashed lines)

\begin{tabular}{|c|c|c|c|c|}
\hline No. & Name & ate & Max Winds, kts ${ }^{a}$ & Minimum Presure, $\mathrm{hPa}$ \\
\hline 1 & No Name & 24 Nov $1912^{4}$ & & $\left(693.08 \mathrm{~mm}^{\mathrm{d}}\right) 923$ \\
\hline 2 & Wanda & 20 Nov 1951 & $90^{\text {JTWC }}$ & $985^{\mathrm{JMA}}$ \\
\hline 3 & Wilma & 27 Oct 1952 & $130^{\text {JTWC }}$ & $930^{\mathrm{JMA}}$ \\
\hline 4 & Tilda & 29 Nov 1954 & $120^{\text {JTWC }}$ & $980^{\mathrm{JMA}}$ \\
\hline 5 & Irma & 15 May 1966 & $100^{\text {JTWC }}$ & $974^{\mathrm{JMA}}$ \\
\hline 6 & Jean & 14 July 1971 & $75^{\text {JTWC }}$ & $980^{\mathrm{JMA}}$ \\
\hline 7 & Kit & 7 Jan 1972 & $75^{\text {JTWC }}$ & $975^{\mathrm{JMA}}$ \\
\hline 8 & Nelson & 25 Mar 1982 & $105^{\text {JTWC }}$ & $940^{\mathrm{JMA}}$ \\
\hline 9 & Axel & 21 Dec 1994 & $95^{\text {JTWC }}$ & $960^{\mathrm{JMA}}$ \\
\hline
\end{tabular}

Sources: "IBTrACS database of Knapp et al. (2010) using either JTWC or JMA data. ; ${ }^{\text {b Algue 1898; ' } A l g u e ~ 1904 ; ~ ' S e l g a ~ 1935 ~}$

\footnotetext{
4 This November 1912 typhoon is believed to be deadly (http://chroniclingamerica.loc.gov/lccn/sn83045433/1912-11-30/ed-1/seq-1/), but other reports on the damage and impact to human life were insufficient for verification (USA War Office 1913).
} 
Leik et al. (1981) noted that many people along the Gulf and Atlantic coasts in the US incorrectly believe they have been through major cyclonic events, although Baker (1991) recognized that defining and measuring hurricane experience is a difficult task. Of particular relevance in the Philippines, several residents on Leyte and Samar islands admitted that their experience of past typhoons misled them to believe that an evacuation lead-time of minutes would be sufficient. This raises a long lasting question: How does the experience of smaller relatively less impactful events shape the response of the community to larger, unprecedented events or those with return periods outside the living memory of residents?

On a broader note, although stronger prehistoric events (Donnelly et al. 2006, Nott 2007) remain to be explored, and as long as other historical events remain unverified, the Ty 1897 and Typhoon Haiyan storm surges may serve as worst-case scenarios for this region. These rare but disastrous events should be carefully evaluated towards enhancing community-based disaster risk awareness, planning, and response.

\subsection{Conclusion}

Historical records reveal a predecessor to Typhoon Haiyan occurred on 12 October 1897. This typhoon referred here as Ty 1897 took a similar path of destruction through the eastern central Philippines. Ty 1897 and Haiyan had almost identical typhoon tracks, but Typhoon Haiyan was more intense, had larger maximum wind coverage, and moved faster than Ty 1897. Our combined field observations and eyewitness 
accounts corroborates with computer simulations illustrate that Typhoon Haiyan's storm surge was about twice the height of the 1897 event in San Pedro Bay, but the two storm surges had similar heights on the open Pacific coast such as at Hernani. While stronger prehistoric events remain unexplored, Ty 1897 and Typhoon Haiyan storm surges may serve as extreme scenarios for this region in terms of disaster risk awareness, planning, and response.

\section{Acknowledgements}

This work comprises Earth Observatory of Singapore contribution no. 95. This research is supported by the National Research Foundation Singapore and the Singapore Ministry of Education under the Research Centres of Excellence initiative. Additional funding for the Filipino scientists has come from the Department of Science and Technology, Republic of the Philippines. We thank Antonia Yulo-Loyzaga of Manila Observatory who provided the Algué report. We acknowledge John Elton Chua, Mikko Garcia, Angel Doctor, Sorvigenaleon Ildefonso for helping us gather data in the field. We are grateful to Chris Landsea and three anonymous reviewers, whose comprehensive and insightful reviews significantly improved the manuscript. Comments from Kelvin Rodolfo, Chris Gouramanis, and Aron Meltzner were valuable in refining the final version. 


\section{References}

Algué, J., 1898: El baguio de Samar y Leyte, 12-13 de Octubre de 1897, Manila Observatory, 1-74.

Algué, J., 1904: The cyclones of the Far East. Bureau of Public Printing, Manila, 283 pp.

Alojado, D. and D.M. Padua, 2010: "Worst Typhoons of the Philippines 1947-2009" [Available online at http://www.typhoon2000.ph/stormstats/WorstPhilippineTyphoons.htm].

Amadore, L. A., 2013: Storm surge in Basey, Samar. [Available online at http://opinion.inquirer.net/66477/storm-surge-in-basey-samar.]

Atkinson, G. D., and C. R. Holliday, 1977: Tropical cyclone minimum sea level pressure/maximum sustained wind relationship for the western North Pacific. Mon. Wea. Rev., 105, 421-427.

Bacani, L., 2013: Deadliest, most destructive cyclones of the Philippines. [Available online at http://www.philstar.com/headlines/2013/11/11/1255490/deadliestmost-destructive-cyclones-philippines.]

Baker, E. J., 1991: Hurricane evacuation behavior. International Journal of Mass Emergencies and Disasters, 9, 2, 287-310.

Bricker, J., H. Takagi, E. Mas, S. Kure, B. Adriano, C. Yi, and V. Roeber, 2014: Spatial variation of damage due to storm surge and waves during Typhoon Haiyan in the Philippines. Journal of Japan Society of Civil Engineers, Ser. B2 (Coastal Engineering), 70, 2, I_231-I_235.

Caulderwood, K. 2014: The Ten Most Expensive Natural Disasters In 2013. [Available online at http://www.ibtimes.com/report-ten-most-expensive-natural-disasters2013-1540058.]

Donnely, C., N. Kraus, and M. Larson, 2006: State of knowledge on measurement and modeling of coastal overwash. J. Coastal Res., 22, 4, 965-991.

Dvorak, V. F., 1975: Tropical cyclone intensity analysis and forecasting from satellite imagery. Mon. Wea. Rev., 103, 420-430. 
Dvorak, V. F., 1984: Tropical cyclone intensity analysis using satellite data. NOAA Tech.Rep. NESDIS 11, 50 pp. [Available online at $\mathrm{ftp}: / /$ satepsanone.nesdis.noaa.gov/Publications/Tropical/Dvorak_1984.pdf.]

Egbert, G.D., and S.Y. Erofeeva, 2002: Efficient inverse modeling of barotropic ocean tides. J. Atmos. Ocean. Technol., 19, 183-204.

Emanuel, K. A., 2005a: The hunters. Divine wind:The history and science of hurricanes, Oxford University Press, New York, 193-202.

Emanuel, K. A., 2005b: The storm surge. Divine wind:The history and science of hurricanes, Oxford University Press, New York, 147-152.

Federal Emergency Management Agency (FEMA), 2011: Coastal Construction Manual FEMA-P55 Vol. 1, U.S. Department of Homeland Security, 3-31 - 3-34.

Flater, D., 1998: XTide: Harmonic tide clock and tide predictor. [Available online at http://www.flaterco.com/xtide/ ] .

Fritz, H.M., and Coauthors, 2007: Hurricane Katrina Storm Surge Distribution and Field Observations on the Mississippi Barrier Islands. Estuarine, Coastal Shelf Sci., 74, 12-20.

Fritz, H.M., C.D. Blount, S., Thwin, M.K. Thu, and N. Chan, 2009: Cyclone Nargis storm surge in Myanmar. Nature Geoscience, 2, 448-449.

Fritz, H.M., and Coauthors, 2012: 2011 Japan tsunami current velocity measurements from survivor videos at Kesennuma Bay using LiDAR. Geophys. Res. Lett., 39, L00G23: doi:10.1029/2011GL050686.

Harris, L.D., 1963: Characteristics of the hurricane storm surge. U.S. Weather Bureau, Technical Paper No. 48, Weather Bureau, 19-24.

Holland, G.J., 1980: An analytic model of the wind and pressure profiles in hurricanes. Mon. Wea. Rev., 108, 1212-1218.

International Research Institute of Disaster Science (IRIDeS), 2014: Initial Report of IRIDeS Fact-finding missions to Philippines. Tohoku University, $105 \mathrm{pp}$.

Irish, J. L., D. T. Resio, and J. J. Ratcliff, 2008: The influence of storm size on hurricane surge. J. Phys. Oceanogr., 38, 2003-2013, doi:10.1175/2008JPO3727.1. 
Joint Typhoon Warning Center, 2014. JTWC Western North Pacific Best Track Data 2013. [Available online at http://www.usno.navy.mil/NOOC/nmfcph/RSS/jtwc/best_tracks/wpindex.php ].

Knaff, J.A. and R. M. Zehr, 2007: Reexamination of tropical cyclone wind-pressure relationships. Wea. Forecasting, 22, 71-88.

Knapp, K.R., M.C. Kruk, D.H. Levinson, H.J. Diamond, and C.J., Neumann, 2010: The International Best Track Archive for Climate Stewardship (IBTrACS): Unifying tropical cyclone best track data. Bull. Amer. Meteor. Soc., 91,363-376.

Koba, H., T. Hagiwara, S. Asano, and S. Akashi, 1990: Relationships between CI number from Dvorak's technique and minimum sea level pressure or maximum wind speed of tropical cyclone (in Japanese). J. Meteor. Res., 42, 59-67.

Kruk, M.C., P.A. Hennon, and K.R. Knapp, 2011: On the use of the Dvorak Current Intensity as a climate data record in the Western North Pacific. $91^{\text {st }}$ AMS Annual Meeting-2 $3{ }^{\text {rd }}$ Conference on Climate Variability and Change. Paper \#142. [Available online at https://ams.confex.com/ams/91 Annual/webprogram/Session25263.html].

Lander, M., C. Guard, and S.J. Camargo, 2014: Super Typhoon Haiyan. State of the Climate 2013. Bull. Amer. Meteor. Soc., S112-114.

Lawrence, H., and H. Cobb, 2005: National Hurricane Center Tropical Cyclone Report on Hurricane Jeanne. [Available online at http://www.nhc.noaa.gov/pdf/TCRAL112004_Jeanne.pdf.]

Leelawat, N., C. M. R. Mateo, S. M. Gaspay, A. Suppasri, and F. Imamura, 2014: Filipinos' views on the disaster information for the 2013 Super Typhoon Haiyan in the Philippines. International Journal Sustainable Future for Human Security J-SustaiN, 2, 2, 16-28.

Leik, R. K., T. M. Carter, J. P. Clark, S. D. Kendall, and G. A. Gifford, 1981: Community Response to Natural Hazard Warnings. Summary Final Report. DCPA01-79-C-0214, FEMA Work Unit No. 2234-F, 77 pp. [Available online at

http://oai.dtic.mil/oai/oai?verb=getRecord\&metadataPrefix=html\&identifier=A 
DA099509 ].

Lesser, G.R., J.A. Roelvink, J.A.T.M. van Kester, and G.S. Stelling, 2004:

Development and validation of a three-dimensional morphological model.

Coast. Eng., 51, 883-915.

Mas, E., and Coauthors, 2015: Field survey report and satellite image interpretation of the 2013 Super Typhoon Haiyan in the Philippines. Natural Hazards and Earth System Sciences, 15, 805-816.

Morgerman, J., 2014: Super Typhoon HAIYAN in Tacloban City \& Leyte, Philippines. [Available online at http://www.icyclone.com/upload/now/apr_2014/iCyclone_HAIYAN_in_Taclob an_City_040314.pdf.]

Mori, N., and Coauthors, 2014: Local amplification of storm surge by Super Typhoon Haiyan in Leyte Gulf. Geophys. Res. Lett., 41, 5106-5113.

Nakazawa, T. and S. Hoshino, 2009: Intercomparison of Dvorak Parameters in the tropical cyclone datasets over the Western North Pacific. SOLA, 5, 33-36, doi:10.2151/sola.2009-009.

National Disaster Risk Reduction and Management Council (NDRRMC), 2013a: Severe Weather Bulletin No.1 Re: Typhoon "Yolanda" (Haiyan). [Available online at

http://www.ndrrmc.gov.ph/attachments/article/1124/ADV\%20re\%20SWB\%201 \%20for\%20TY\%20YOLANDA\%20(06NOV2013).pdf]

National Disaster Risk Reduction and Management Council (NDRRMC), 2013b:

Situational Report No. 10 Effects of Typhoon Yolanda (Haiyan) as of 10 November 2013. [Available online at http://www.ndrrmc.gov.ph/attachments/article/1125/NDRRMC\%20Update\% 20SitRep $\% 20$ no. $\% 2010 \% 20$ re $\% 20$ Effects $\% 20$ of $\% 20$ TY\%20Yolanda, $\% 2010$ \%20Nov\%202013,\%206AM.pdf.]

National Disaster Risk Reduction and Management Council (NDRRMC), 2013c:

Situational Report No. 3. Preparations for Typhoon "Yolanda" (Haiyan). [Available online at 
http://www.ndrrmc.gov.ph/attachments/article/1124/Update\%20SWB\%20No \%203\%20TY\%20YOLANDA\%2007\%20NOV\%202013,\%2011AM.pdf.]

National Disaster Risk Reduction and Management Council (NDRRMC), 2014:

Situational Report No. 108 Effects of Typhoon "Yolanda" (Haiyan) as of 3

April 2014. [Available online at

http://www.ndrrmc.gov.ph/attachments/article/1125/NDRRMC\%20Update\%

20-\%20Sitrep\%20No\%20108\%20re\%20TY\%20Yolanda\%20-

\%2003\%20April\%202014.pdf.]

National Mapping and Resource Information Authority, 1980: Nautical chart of San Pedro Bay. 1:40,000. Sheet 4468. Manila, Philippines. Print.

Needham, H.F., and B. D. Keim, 2014: Correlating Storm Surge Heights with Tropical Cyclone Winds at and before Landfall. Earth Interactions, 18,7, 1-26.

Nott, J., 2007: The importance of Quaternary records in reducing risk from tropical cyclones. Palaeog., Palaeoclimatol., Palaeoecol, 251, 137-149.

Paciente, R.B., 2014: Response and lessons learned from Typhoon "Haiyan" (Yolanda). JMA/WMO Workshop on Effective Tropical Cyclone Warning in Southeast Asia. Tokyo, Japan Meteorological Agency. [Available online at http://severe.worldweather.wmo.int/TCFW/JMAworkshop/63.THaiyan_RPaciente.pdf]

Philippine Atmospheric, Geophysical and Astronomical Services Administration (PAGASA), 1998: Storm surge occurrences from 1800 to 1998. Compiled by Climatology and Agrometeorology Branch, 1-7.

Ranada, P., 2013: Leyte warned of storm surges. [Available online at http://www.rappler.com/nation/43179-yolanda-storm-surges.]

Ribera, P., R. García-Herrera, and L. Gimeno, 2008: Historical deadly typhoons in the Philippines. Weather, 63,194-199.

Selga, M., 1935: Charts of remarkable typhoons in the Philippines 1902-1934. Catalogue of typhoons 1348-1934, Manila Weather Bureau, 1-55. 
Tadepalli, S., and C.E. Synolakis, 1994: The run-up of N-waves on sloping beaches. Proc. R. Soc. Lond. A., 445, 99-112.

Tajima, Y., and Coauthors, 2014: Initial report of JSCE-PICE joint survey on the storm surge disaster caused by Typhoon Haiyan. Coast. Eng. J., 5, doi:10.1142/S0578563414500065.

Udías, A., 1996: Jesuits' contribution to meteorology, Bull. Am. Meteorol. Soc., 77, $2307-2315$.

UNESCO, 2014: International Tsunami Survey Team (ITST) Post-Tsunami Survey Guide, 114p, UNESCO-IOC Manuals and Guides, 37, 2nd Edition, Paris, France.

USA War Office, 1913: Typhoons. Report of the Philippine Commission to the Secretary of War. Washington, 32.

Velden, C., and Coauthors, 2006: The Dvorak tropical cyclone intensity estimation technique: A satellite-based method that has endured for over 30 years. Bull. Amer. Meteor. Soc., 87, 1195-1210, doi:10.1175/BAMS-87-9-1195.

World Meteorological Organization, 2015: Typhoon Committee Operational Manual. Tropical Cyclone Program Report No. TCP 23, 169 pp. [Available online at https://www.wmo.int/pages/prog/www/tcp/documents/TCP23EDITION2015.pdf 


\section{Chapter 3}

\section{Sedimentary record of Typhoon Haiyan from Leyte Gulf coastlines shows a hybrid signature}

Janneli Lea A. Soria ${ }^{1,2}$, Adam D. Switzer ${ }^{1,2}$, Jessica E. Pilarczyk ${ }^{3}$, Fernando P.

Siringan $^{4}$, Nicole S. Khan ${ }^{5}$, Hermann M. Fritz ${ }^{6}$

${ }^{1}$ Asian School of the Environment, Nanyang Technological University, Singapore 639798

${ }^{2}$ Earth Observatory of Singapore, Nanyang Technological University, Singapore 639798

${ }^{3}$ Department of Marine Science, University of Southern Mississippi

1020 Balch Blvd., Stennis Space Center, MS 39529-9904

${ }^{4}$ Marine Science Institute, University of the Philippines, Diliman, Quezon City, Philippines 1101

${ }^{5}$ United States Geological Survey, St. Petersburg Coastal and Marine Science

Center, St. Petersburg, Florida 33701-4846

${ }^{6}$ School of Civil and Environmental Engineering, Georgia Institute of Technology, Atlanta, GA 30332

For submission to: Sedimentary Geology

Keywords: Haiyan, overwash, storm deposit 


\section{Contributions}

Lea was the primary author, and with Adam, and Fernando conceptualized the idea, contributed to its formality and development. Lea conducted the sedimentological analysis, interpreted the data, and wrote the paper. Jessica collected, analyzed, and contributed relevant micropaleontological data. Nicole and Hermann collected data, and contributed information on data treatment and interpretation.

Janneli Lea A. Soria: $65 \%$

Adam D. Switzer: $12 \%$

Jessica E. Pilarczyk: 10\%

Fernando P. Siringan: 6\%

Nicole S. Khan: $4 \%$

Hermann M. Fritz: 3\% 


\section{Abstract}

Overwash associated with the 5 to $8 \mathrm{~m}$ storm surge of Typhoon Haiyan left overwash sediments inland, on the coastal plain of the northwestern shores of Leyte Gulf, Philippines. We studied two locations no more than $20 \mathrm{~km}$ apart that experienced similar storm surge conditions. At both locations the Haiyan sediments were predominantly sand and silt, which provide a modern sedimentary record of storm surge deposition from a Category 5 landfalling typhoon. Notably, despite the similar storm surge conditions at the two sites, significant differences in sediment grainsize, composition and sorting exist. This variability is reflective of the local geology showing the different sediment composition and the availability for transport of the sediments in the nearshore environment. Thicker overwash sediments on the broad, low-lying, silicilastic coast of Tanauan exhibit planar stratification, a coarsening upward sequence, an overall but non-systematic landward fining trend, and a sharp depositional (rarely erosional) basal contact with the underlying landform. These sedimentologic and stratigraphic characteristics are consistent with other overwash sediments from comparably intense storm surges, and were also observed in recent tsunami deposits. 


\subsection{Introduction}

Overwash associated with storm surges during land-falling storms often rework, erode and transport near-shore sediments into low-lying coastal plains (Leatherman, 1981; Morton \& Sallenger, 2003; Williams \& Flanagan, 2009). The overwash sediments are commonly reported as anomalous sand layers found in the sedimentary environments of low-energy coastal settings, including coastal lakes, swamps and back-barrier tidal marshes (e.g. Leatherman, 1977; Liu and Fearn, 1993; Donnelly et al., 2004; Buynevich et al., 2004). Overwash processes also create depositional landforms on back beach environments. Depending on the elevation of water surface level relative to the dune or beach ridge height, along with the extent and continuity of foredune gaps, overwash can either result in washover fans that are isolated, regularly spaced, or merged to form terrace morphology (Morton and Sallenger, 2003). These sedimentary and geomorphic products of storm-induced overwash although distinct, can be very diverse. In a recent review paper, Otvos (2011) cautioned the use of the sedimentary and geomorphic storm markers in prehistoric storm reconstructions. He argued that poor understanding of the dynamic interactions amongst several meteorological, hydrodynamic, and geologic conditions that determines the intensity of flooding, erosion, transport, deposition of sand layers during storm events including postdepositional preservation may result in unreliable sedimentologic-based prehistoric reconstructions of the frequency and the intensity of storm events. Although his review only covered paralic basins and barrier islands, the framework seems to be conceptually applicable to any low-lying coastal environment. The limitations, however true to some extents, do not diminish the capability of sedimentary and geomorphic products of modern storms as tools in understanding storm impacts to 
coastlines in so far as coastal dynamics, long-term evolution, or hazard assessments are concerned (e.g. Nott and Hubbert, 2006; Houser et al., 2008; Williams, 2013).

In the Philippines, despite the high frequency of storms (locally referred to as bagyo) there is limited information on the dynamics and impacts of local storm surges. The state agency PAGASA (Philippine Atmospheric, Geophysical and Astronomical Services Administration) has a compilation list and a map of the historical storm surge occurrences in the Philippines between 1897 and 2011. But apart from the October 1897 typhoon (Algue, 1898), we lack detailed studies on the nature and local impact of storm surges. To the local coastal communities, little is known about the immediate devastating impacts of storm surge until the Typhoon Haiyan disaster in 2013. Typhoon Haiyan is now considered as the strongest and fastest moving typhoon at landfall not only in the Philippines (Takagi and Esteban, 2016) but also worldwide (Lin et al., 2014). In as much as Typhoon Haiyan was strong, it also generated a storm surge of 5 to $8 \mathrm{~m}$ that engulfed the northwestern shores of the Leyte Gulf over a very short period of $\sim 1$ hour (Soria et al., 2016). Notably, Typhoon Haiyan's bore-like storm surge is rare compared to the more commonly reported gradual rise inundation associated with similarly intense storm and storm surge (Mikami et al., 2016). In this study, we describe the physical sedimentology of the overwash sediments resulting from the Typhoon Haiyan storm surge at two localities in central eastern Philippines. A separate study by Pilarczyk and others (2016) documented the micropaleontological assemblages contained within the Typhoon Haiyan overwash sediments at our sampling locations. 
Typhoon Haiyan provided a unique opportunity to study modern overwash sedimentation across two coastal plains no more than $20 \mathrm{~km}$ apart but represent constrasting sedimentological regimes, namely a siliciclastic coast and a mixed siliciclastic-carbonate coast. Given the similar hydrodynamic storm surge conditions between the two sites, we examined the possible influence of local factors such as coastal morphology and sediment source on overwash deposition. In addition, Typhoon Haiyan overwash sediments represent a rare sediment record of an intense landfalling storm with bore-like storm surge. The Haiyan overwash sediments were then compared to other overwash sediments from recent tsunamis and storms in an attempt to identify sedimentological characteristics that could be diagnostic.

\subsection{Typhoon Haiyan}

Typhoon Haiyan, locally known as Yolanda, was a Category 5 typhoon according to the Safirr-Simpson Hurricane Scale when it made landfall on Tacloban (Fig. 3.1a). The most extensive infrastructure damage and highest death toll from Typhoon Haiyan was mainly due to the high storm surge (Tajima et al., 2014; Mas et al., 2015). The storm surge in San Pedro Bay is initially characterized by a sealevel drawdown of $\sim 2 \mathrm{~m}$ that exposed wide expanses of the gently sloping subtidal sand flats along the northern shores of the bay (Soria et al., 2016; Chapter 2). Soon after Typhoon Haiyan's landfall in Leyte island, the storm surge came rapidly onshore as a fast-moving wall of water exceeding $5 \mathrm{~m}$ high (Fig. 3.1b). Wave contributions raised high-water mark indicators to almost $8 \mathrm{~m}$ in Tacloban and Palo (Soria et al., 2016). The peak water levels lasted for 30 to 45 minutes before rapidly subsiding within 1 to 2 hours. Within the short inundation duration, 
survivor accounts and storm surge simulations corroborate the occurrence of three wave sets (Soria et al., 2016). On the northern shore of San Pedro Bay, storm surge flooding at Basey reached $\sim 800 \mathrm{~m}$ inland; whereas, on the western shore near Tanauan, flooding reached up to $2 \mathrm{~km}$ inland. The greater inundation of Typhoon Haiyan in Tanauan is primarily due to the low-lying, gently sloping terrain of the coast compared to the relatively irregular topography of raised carbonate platforms and rice paddies on terraced slopes in Basey.

\subsection{Study Area}

San Pedro Bay is a $\sim 20 \mathrm{~km}$ wide by $\sim 25 \mathrm{~km}$ long embayment that opens to the larger Leyte Gulf to the south. To the northwest San Pedro Bay narrows into the San Juanico Strait that separates the islands of Leyte and Samar. As such, the tidal pattern in San Pedro Bay is driven by the complex interaction between the mixed semidiurnal-dominated Leyte Gulf and the mixed diurnal-dominated Samar Sea. San Pedro Bay is relatively shallow (maximum water depth of $\sim 20$ $\mathrm{m}$, average water depth of $\sim 10 \mathrm{~m}$ ) and has an average tidal range of $50 \mathrm{~cm}$ (NAMRIA, 1980 In: PMSL, 2016).

The coastal landscapes surrounding San Pedro Bay have contrasting morphology. The wide, low elevation $(<3 \mathrm{~m})$, coastal plains of the western coast consist of beach ridges, a sand spit and patches of mangrove stands. Here, the coastal plains consist primarily of accumulations of unconsolidated siliciclastic sediments sourced from the interior highlands that are composed of Cretaceous ultramafic-mafic igneous rocks capped with pelagic sedimentary sequences and patches of MiocenePliocene volcanic centers and sedimentary rocks (Aurelio and Pena, 2002; Suerte 
et al., 2005). In contrast, irregularly steep karstic terrains of the Oligocene to Miocene age limestones (Aurelio and Pena, 2002) are found on the northern and eastern shores. Sandy, pocket beaches are found in small embayments and narrow reefs fringe the rocky limestone headlands.
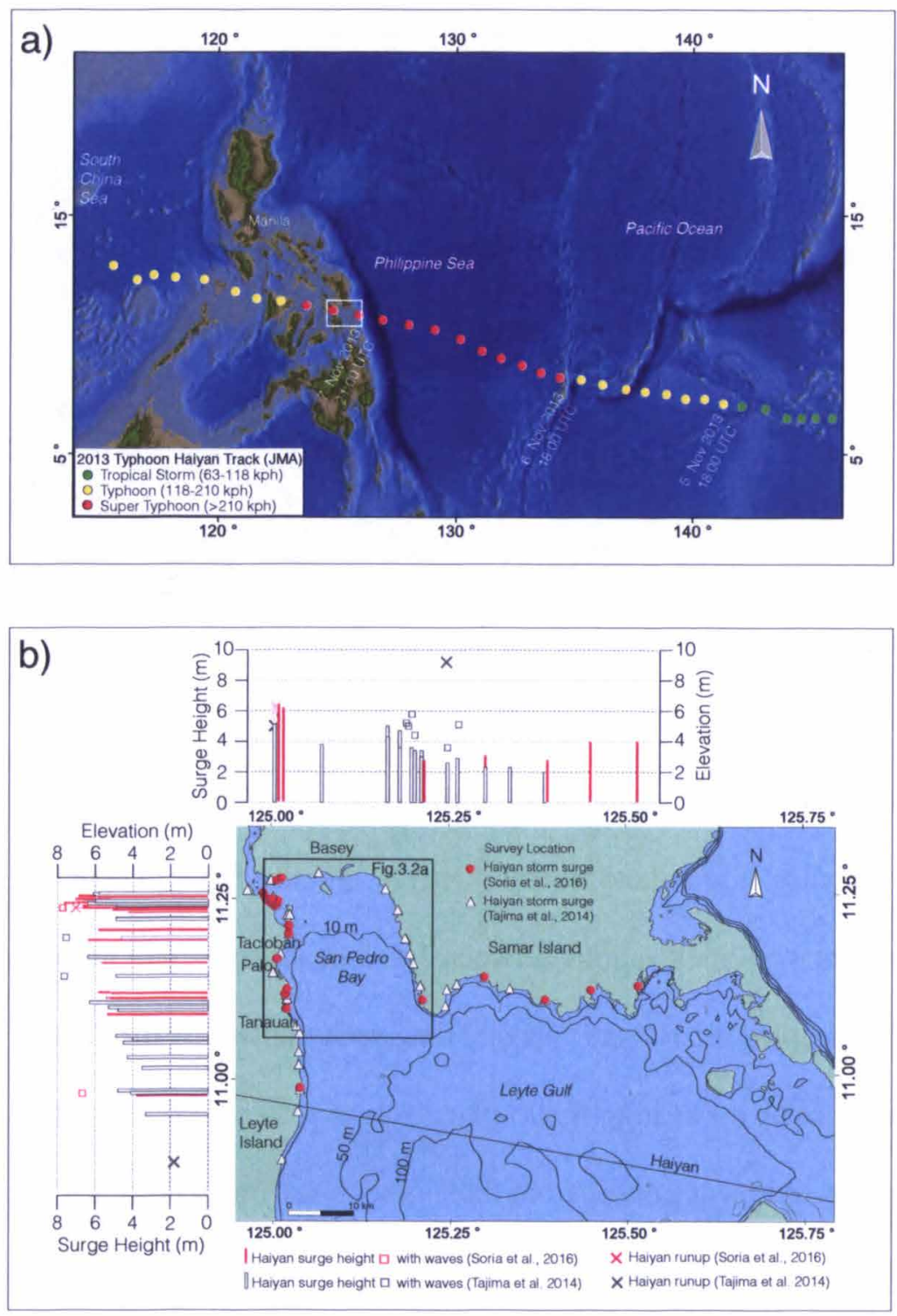

Figure 3.1. Track of Typhoon Haiyan traversing central Philippines (a). Storm surge heights along the coastlines surrounding Leyte Gulf (b). 


\subsection{Methods}

Inland transport and deposition of sediments from Typhoon Haiyan were mapped in San Pedro Bay in January 2014 along four transects on the two different depositional regimes (Fig. 3.2). Three of the four transects were located on the siliciclastic coast of Tanauan and the other on the mixed carbonate-siliciclastic coast of Basey. Surveys and sampling were limited to areas that had minimal disturbance by human activities following Typhoon Haiyan. Each transect extended from the shore to the landward limit of Haiyan deposit, the distance of which varied between $400 \mathrm{~m}$ in Basey to $1.8 \mathrm{~km}$ in Tanauan. Topographic elevations along the transects were determined simultaneously with the high-water mark survey using a Trimble global positioning system (GPS) rover connected via Bluetooth to a Lasercraft XLRic laser range finder (Soria et al., 2016). Geomorphic indicators of beach erosion were also noted such as scouring and exposed roots. We used a handheld GPS to mark all the sampling locations. The transects cover back beach environments including stands of Nypa fruticans (a mangrove-associated palm species), patches of grassland, coconut groves, and rice fields. These environments were at elevations between 1 to $3 \mathrm{~m}$ above present mean sea level. We sampled the Haiyan deposit along each transect by means of a hand gouge auger or by excavating shallow trenches of $\sim 10 \mathrm{~cm}$ deep. At all sites, we collected one sediment sample from the Typhoon Haiyan deposit and one sample from the underlying soil for subsequent sediment grainsize, and sediment composition analyses.

About $1 \mathrm{~g}$ to $2 \mathrm{~g}$ of sediment was taken in each sample to determine both the 

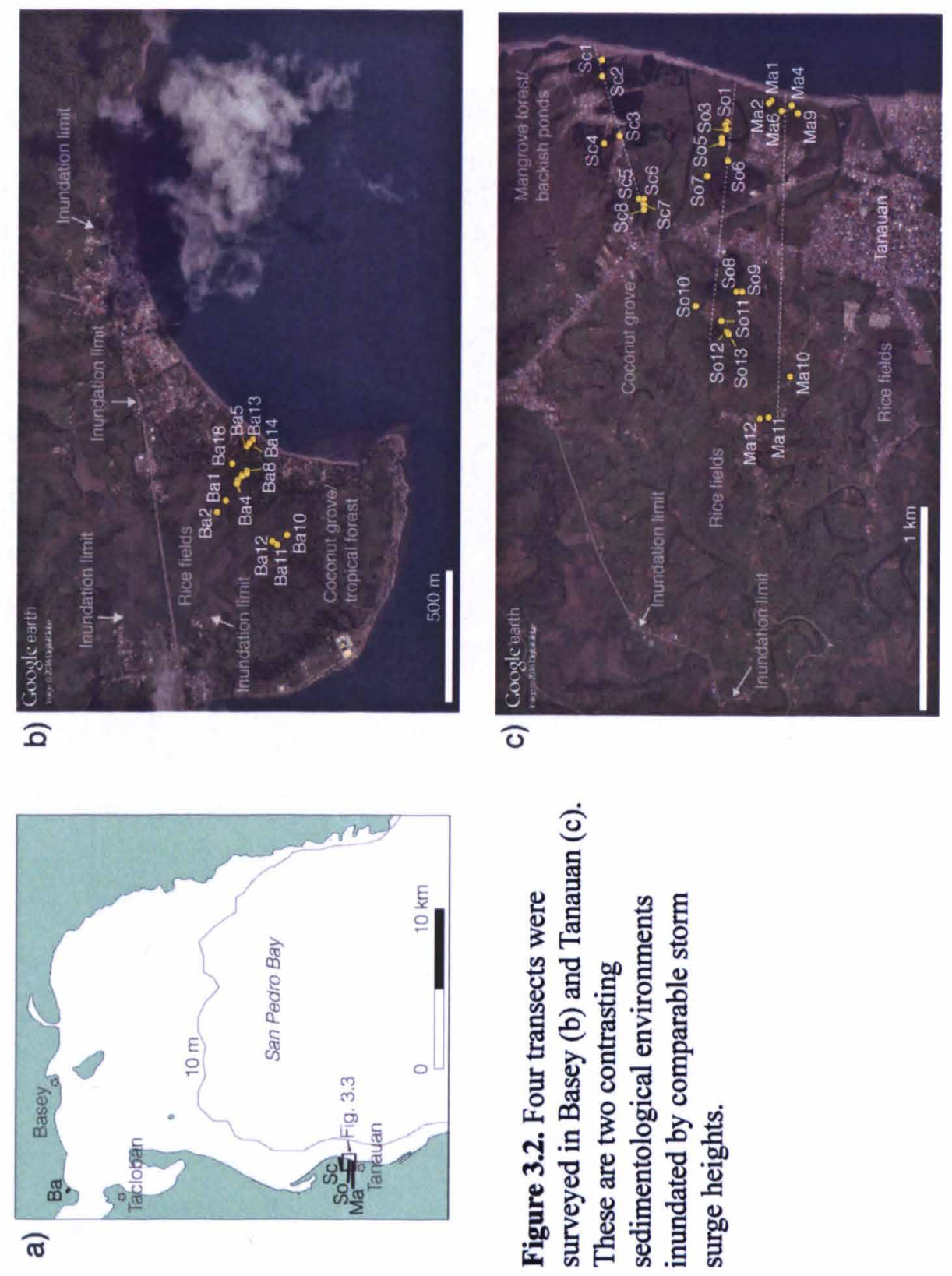
organic and the carbonate content following the loss-on-ignition method by Heiri and others (2001). Another set of subsamples about $1 \mathrm{~g}$ were set apart for grainsize analysis. Samples were treated with $20 \% \mathrm{H}_{2} \mathrm{O}_{2}$ to remove organics and $15 \%$ hydrochloric acid $(\mathrm{HCl})$ to remove carbonate fragments. The carbonaterich sediments of Basey were not treated with $\mathrm{HCl}$. The samples were rinsed in distilled water before introducing to the Malvern Mastersizer 2000 for grainsize analyses using laser diffraction. The grainsize data were then run through the open-source program GRADISTAT version 8.0 (Blott 2001) to generate statistical grainsize distributions. The fraction of sediment by different category size (e.g. clay, very coarse silt, medium sand) along with the logarithmic (Folk and Ward, 1957) mean, median, mode, sorting, and skewness of each sample were used to establish the vertical and across-shore variations of the Haiyan sediments.

Shoreward of transects So and Ma, we found a sandy depositional landform, from the beach extending landwards to the seaward margin of the mangroves and grass stands burying grasses and mangrove roots. On the beach, berm rebuilding by sheet wash deposition from fair weather waves was evident indicating the initial phase of beach recovery has commenced immediately after typhoon Haiyan. We compared pre- and post-typhoon Haiyan Google Earth ${ }^{\mathrm{TM}}$ images accessed through Google Earth Pro to determine whether this landform corresponds to an overwash terrace formed by the storm surge inundation and if it has been modified to some extent since the initial deposition (Fig. 3.3).

For a detailed description of the sedimentary features of the Haiyan sediments, a 

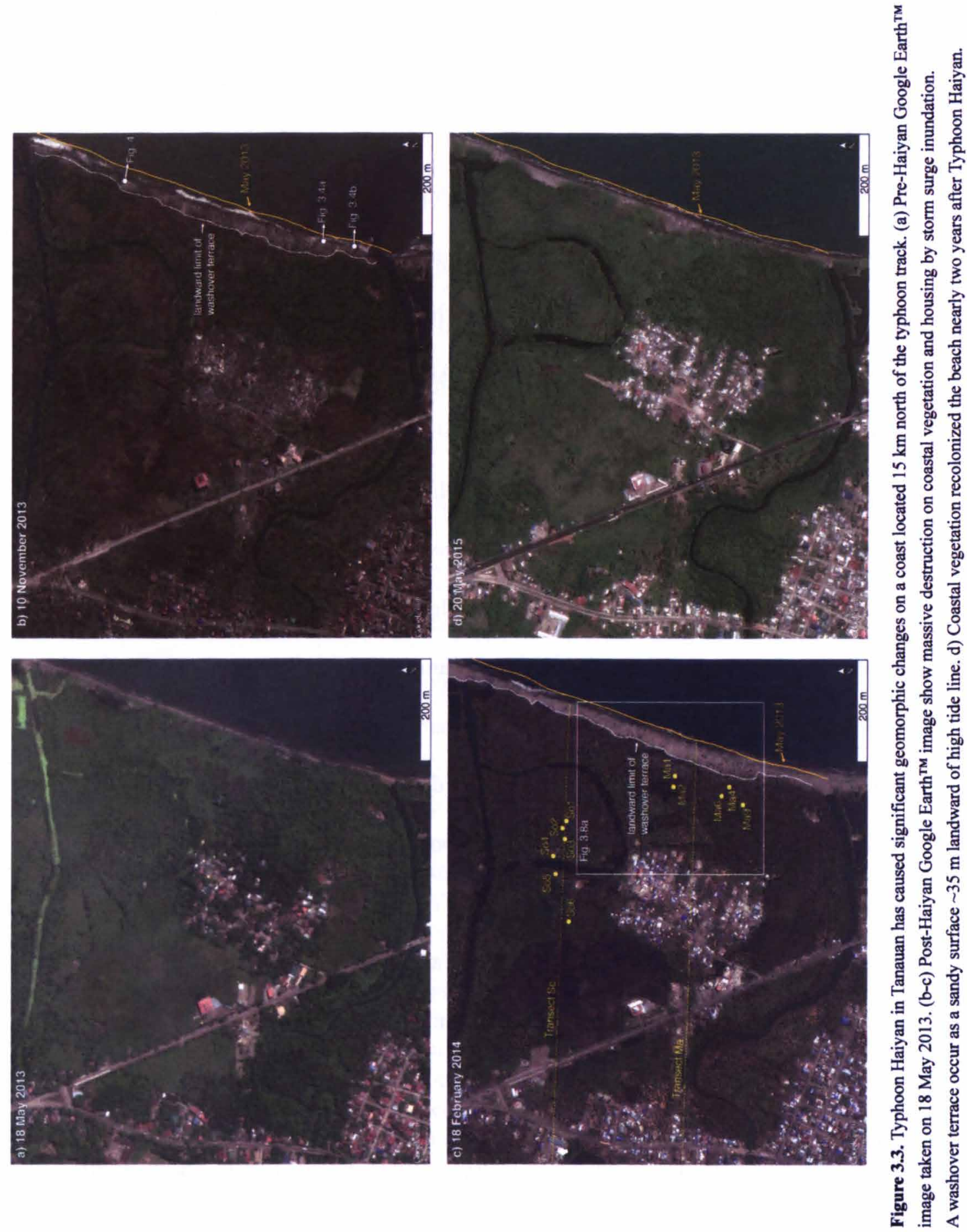
follow-up field survey was conducted in May 2014. An array of six shallow trenches were excavated in two transects oriented perpendicular to the coast, starting from the terminus of a sandy landform identified on the post-typhoon Haiyan satellite image to about $100 \mathrm{~m}$ landward (Figs. 3.3b and 3.3c). The trenches were located on the grassland adjacent to transect Ma that at the time of the initial survey had ponded water of about $50 \mathrm{~cm}$ deep. The trench samples were labeled as MP to distinguish them from the samples taken using auger along transect Ma. The trenches have varying depths depending on the water table, ranging from 25 to $50 \mathrm{~cm}$ from the surface. At each trench, we noted the thickness of the Haiyan deposits, the nature of the basal contact with the underlying landform, and other sediment structures like laminations or apparent grading. Samples from the Haiyan deposits and the pre-Haiyan soil were taken at 1-cm intervals for grainsize analysis. The Haiyan deposits are predominantly coarse grained, with minimal silt or clay. Large organic debris and carbonate shells were picked from the samples using forceps. The samples were rinsed with distilled water to remove the smaller, fibrous organic debris by floatation. The sediments were successively oven dried at $50^{\circ} \mathrm{C}$, and about $50 \mathrm{~g}$ to $100 \mathrm{~g}$ of dry subsamples were introduced on the Retsch Technology CAMSIZER $®$ for grainsize analyses. The CAMSIZER ${ }^{\circledR}$ provides non-destructive and rapid grain size and shape distributions for sediments ranging from 20 microns to 30 millimeters by capturing images of falling curtain of sediment at $25 \mathrm{~Hz}$ (Moore et al., 2006). The grainsize corresponds to the cross-sectional area of the particles in the image and reported as the diameter of a circle of equivalent area, which is similar to the grainsize measuring principle of the laser particle analyzer (Switzer and Pile, 2015). For the finer grained, pre-Haiyan sediment unit, we followed the same methods described 
above for laser particle analysis. The composite grainsize data of the Haiyan deposits and the pre-Haiyan soil were then run through the open-source program GRADISTAT to generate statistical grainsize distributions.

\subsection{Results}

3.5.1. Beach erosion and post-storm beach recovery

The post-storm environment in Tanauan is reflective of the large-scale beach erosion associated with Typhoon Haiyan. Comparison between pre- and postTyphoon Haiyan satellite images indicates $10 \mathrm{~m}$ to $25 \mathrm{~m}$ of erosion from the beach face and berm (Figs. 3.3a \& 3.3b). Coconut stumps now sit $\sim 10 \mathrm{~m}$ seaward of the post-Haiyan beach and re-exhumed organic-rich mangrove soil underlying the unconsolidated beach sands can be found exposed along the beach (Fig. 3.4). Surface elevations of the re-exhumed mangrove soil, and the top of the exposed roots of the coconut trees indicate vertical beach erosion of about 1 to $2 \mathrm{~m}$.

A new landform that consists of sandy sediments extends $\sim 35 \mathrm{~m}$ inland of the high tide line and is visible on Google Earth images following Typhoon Haiyan (Figs. 3.3b \& 3.3c). The sandy landform terminates along the seaward margin of the mangrove stands in an irregularly undulating and in some areas lobate pattern, characteristic of a washover terrace (Morton and Sallenger, 2003). Immediately after Typhoon Haiyan, however, swash deposition and berm rebuilding indicate to some extent beach recovery (Fig. 3.5a). An exploratory trench reveals a laminated sandy beach sequence on the washover terrace (Fig. 3.5b). On the laminated beach sequence, there seems to be a fine line between 
a)

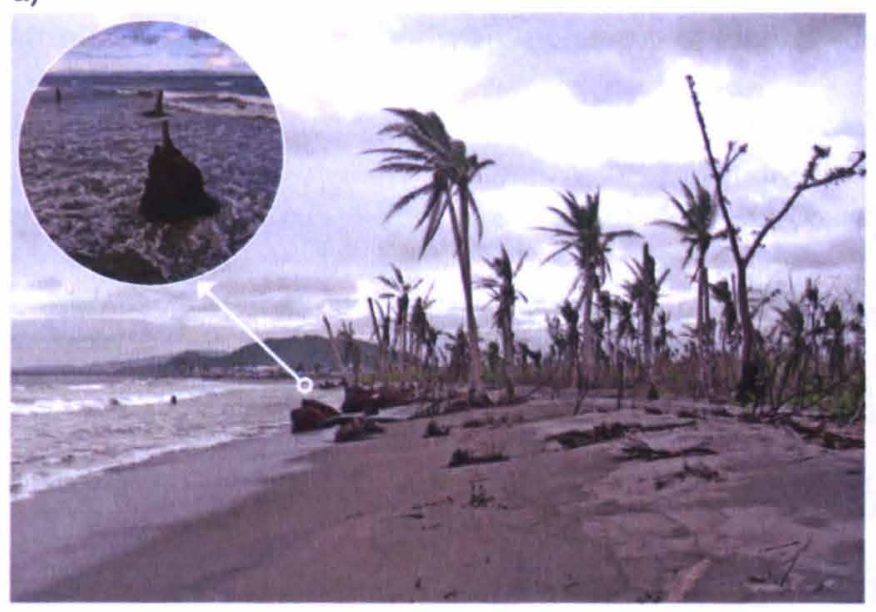

b)

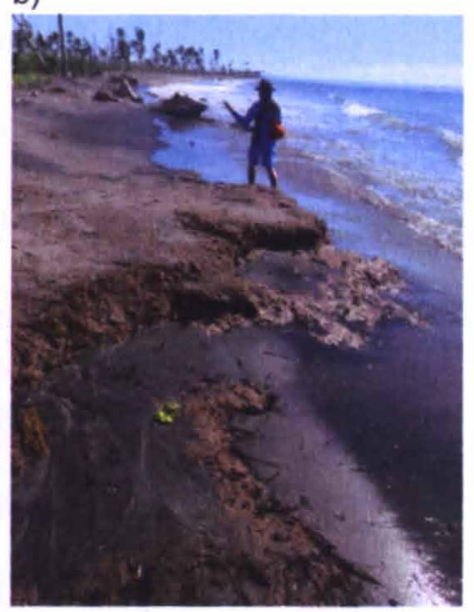

Figure 3.4. Exposed roots of coconuts trees, coconut stumps on the intertidal zone (a), and re-exhumed organic-rich mangrove soil (b) indicate significant beach erosion following Typhoon Haiyan.

a)

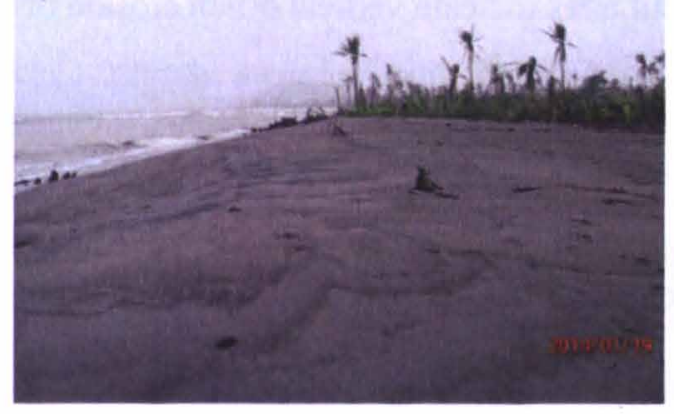

b)

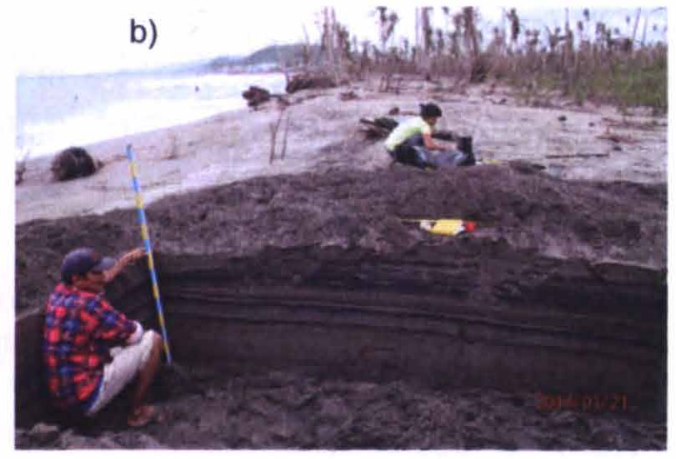

Figure 3.5. Swash actions of waves re-establish a berm on top of the washover terrace (a) strongly indicating immediate beach recovery post-Haiyan in Tanauan. The repeated swash actions deposit laminated sandy beach sequence (b). 
depositions from the Haiyan overwash process with that from the initial phase of beach recovery. Recognizing this limitation, we focus our study to the overwash deposits on the back beach environments, which are minimally influenced by marine processes after the storm.

The rapid establishment of the beach system post-Haiyan indicate the availability of nearshore sandy sediments during fair weather conditions along this coast to assist in beach recovery to commence immediately following an intense typhoon. A Google Earth image taken in May 2015 shows that coastal vegetation has colonized the washover terrace; thereby stabilizing this newly aggraded sandy landform from reworking (Fig. 3.3d).

\subsubsection{Haiyan overwash sediments in Tanauan}

\subsection{2.a. Transect-scale lateral variation}

The Haiyan overwash sediments were identified from the pre-Haiyan soil with varying degree of certainty. On the Nypa forest and grasslands within $200 \mathrm{~m}$ from the shore, the contact between the Haiyan deposit and the underlying soil was pronounced. The Haiyan overwash sediments are gray to beige, and distinctly different from the dark brown underlying pre-Haiyan soil that commonly contained buried upright grasses or root fragments. On the other hand, the contact between the Haiyan overwash sediments and the underlying soil on the rice paddies greater than $400 \mathrm{~m}$ from the shore was very subtle and has started to be obscured by rapid post-typhoon vegetation growth. 
The Haiyan overwash sediments on the silicilastic coast of Tanauan display notable across-shore textural and compositional variations, but not necessarily systematic trends (Figs. 3.6a-c). Along each of the transects (Sc, So, and Ma), the Haiyan deposits have variable thickness, thickest accumulations of 5 to 7 $\mathrm{cm}$ were consistently found in mangrove stands and depressions (shallow ponds) between 200 to $400 \mathrm{~m}$ from the shore. These thick Haiyan sediments are predominantly gray, moderately- to well-sorted, fine to coarse sand that contain low amounts of organic matter $(<10 \%)$ and carbonate $(<1 \%)$. Beyond $500 \mathrm{~m}$ from the shore, rice paddy fields are blanketed by $1-\mathrm{cm}$ to $3-\mathrm{cm}$ thick silt to very fine sand. The thin sand sheet extends to $\sim 1.6 \mathrm{~km}$ inland and are very poorly sorted, and contain relatively higher amounts of organic matter ( $>10 \%-$ $35 \%$ ) and carbonate (1-2\%). Collectively, the overwash sediments less than 400 $\mathrm{m}$ from the shore are distinctly coarser grained, better sorted, and containing less organic matter $(<10 \%)$ than the overwash sediments found greater than $400 \mathrm{~m}$ from the shore. This distinct sedimentologic difference with distance is consistent with the observed change in the assemblage and test size of the foraminifera, and the change in abundance of testate amoebae (Pilarczyk et al., 2016).

\subsection{2.b. Trench-scale vertical variation}

Slightly on landward terminus of the washover terrace, behind a swale, trenches MP 4 and MP 7 revealed two different sedimentary units that overlie the preHaiyan soil surface. In trench MP 4 , Unit 1 is a $\sim 10 \mathrm{~cm}$ thick accumulation of black, magnetite-rich, medium sand that coarsens upwards (Fig. 3.7). The sands of Unit 1 are moderately sorted with sorting values remaining constant at $\sim 0.75$ 


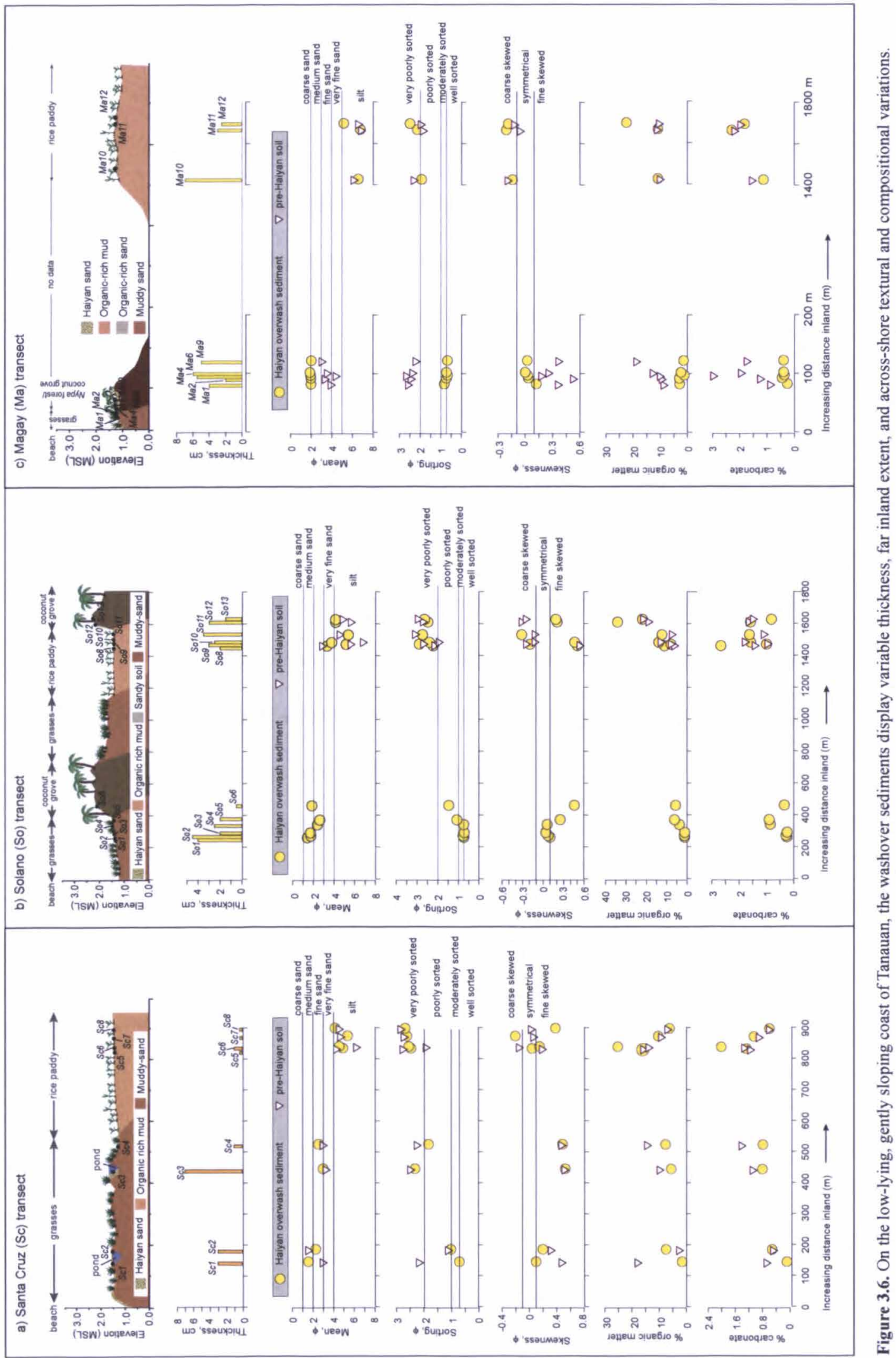


$\phi$. Thin planar laminations within the magnetite-rich Unit 1 sand were observed on the across-shore wall of trench MP7 (Fig. 3.8a). The planar structure, however, appears wavy on the along-shore trench wall (Fig. 3.7b). The magnetite-rich sand, Unit 1 is overlain by $12-\mathrm{cm}$ thick light gray, coarse sand, Unit 2 (Figs. $3.7 \&$ 3.8a). The contact between the two sediment units is very sharp, and for the most part conformable but in one instance erosional (Fig. 3.8b). Figure 7 shows the bulk sediment mean grain size, and the gravel fraction show that the base of Unit 2 is characterized by relatively high concentrations of gravel-sized sediments displaying a fining upwards trend. But, at $5 \mathrm{~cm}$ from the surface the initial fining upward sequence shifted to a coarsening upward to the surface. In contrast, the vertical grading in trench MP7 is not as complex as in trench MP 4. Figure $3.8 \mathrm{c}$ shows the bulk sediment mean grainsize in MP7 indicate a single and consistently coarsening upward sequence. Despite the textural grading trend in grainsize, sorting remains uniform, and the entire sequence is composed of moderately sorted sediments. The laminated, magnetite-rich basal unit (Unit 1) did not persist beyond $50 \mathrm{~m}$ from the shore. Inland trenches MP6 and MP1 revealed thinner Haiyan overwash sediments, which consist of light gray, medium sand (Fig. 3.9). 


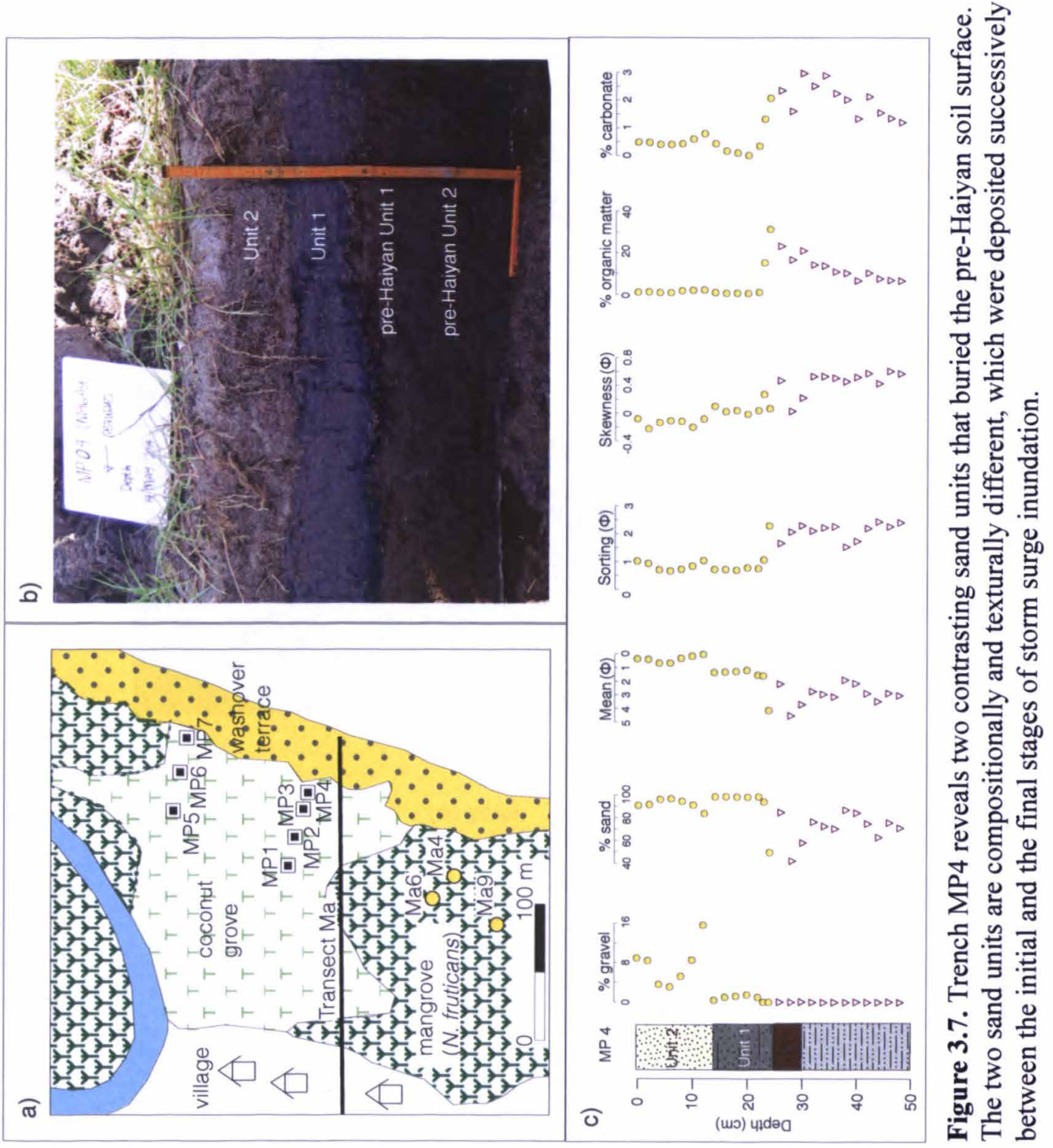



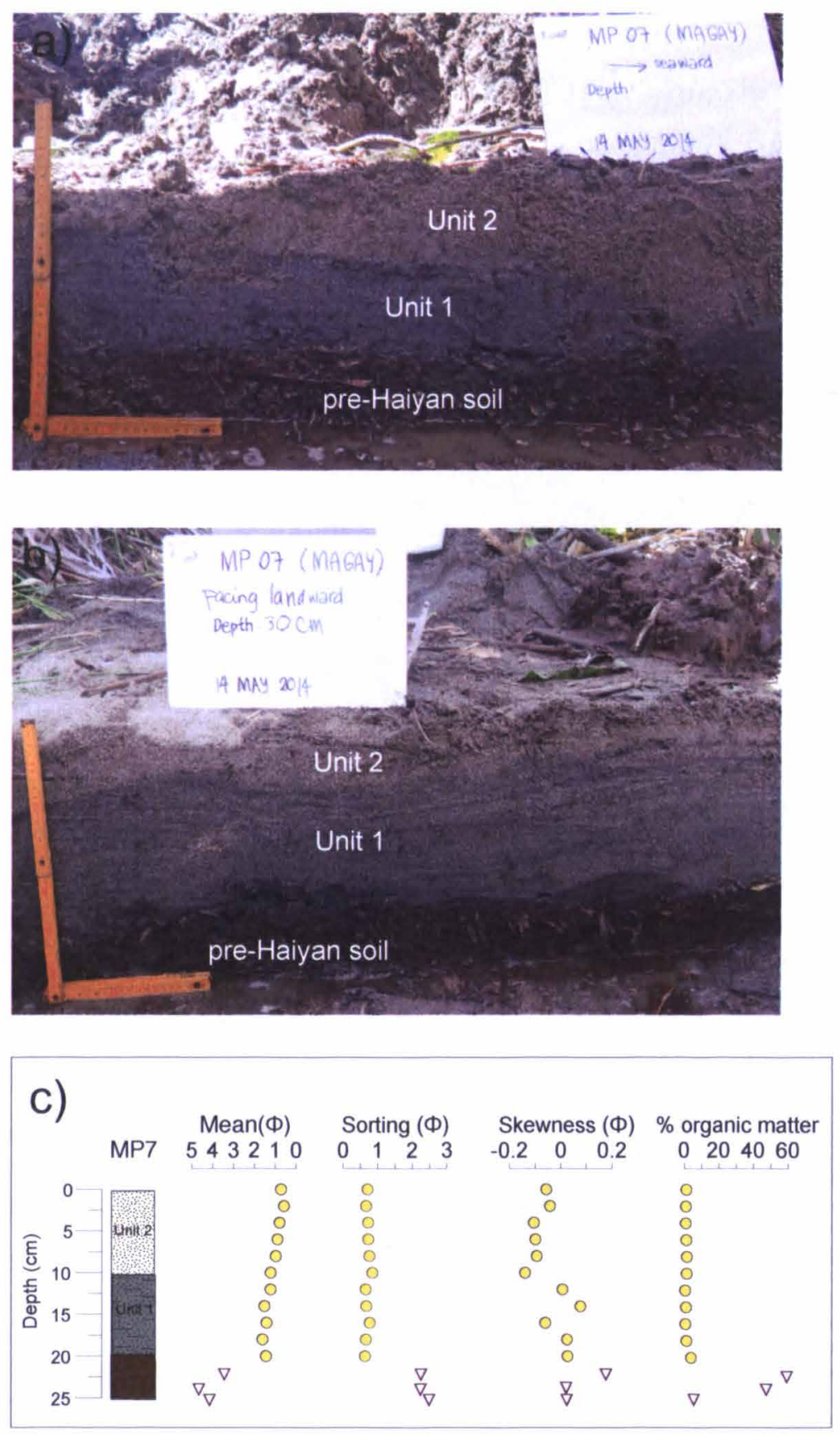

Figure 3.8. The two contrasting sand units in MP4 are consistently seen on the pit walls in trench MP7. The sandy bottom layer, Unit 1 exhibits distinct laminations $(a, b)$. The upper sandy layer, Unit 2 has sharp and erosional contact with Unit1 (b). These two sandy units display overall coarsening upward trend (c) indicating hyperconcentrated, elevated, high-velocity flow. 

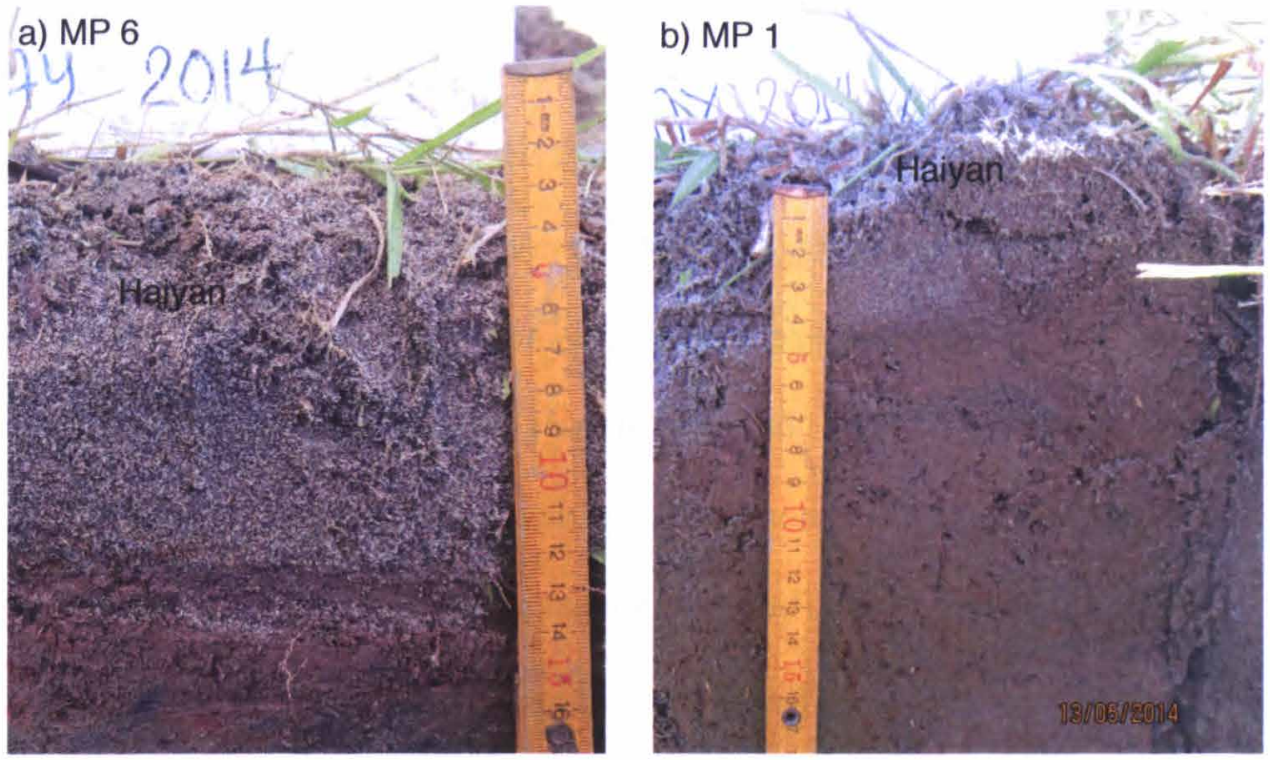

Figure 3.9. Unstratified sand sheet of Typhoon Haiyan on a section in trench MP 6 (a) and trench MP 1(b).

\subsubsection{Haiyan overwash sediments in Basey}

Similar to Tanauan, the Haiyan overwash sediments in Basey were identified from the pre-Haiyan soil with varying degree of certainty depending on the coastal environment and distance from the shore. The Haiyan sediments on the coconut grove within $200 \mathrm{~m}$ from the shore overlies the light brown, finergrained pre-Haiyan sediments, blanketed by thin veneer of dark brown, organicrich soil. The nature of the contact between the Haiyan sediments and the underlying soil, either depositional or erosional is uncertain, but was generally sharp, and very pronounced. Farther inland on the rice paddies, the contact between the slightly lighter colored Haiyan sediments and the darker underlying soil due to higher organics is barely recognizable. Dense re-vegetation on the 
rice paddies has obscured the contact within two months after Haiyan's landfall. The Haiyan overwash sediments are beige, poorly-sorted, silt to fine sand that drapes the beach berm, coconut grove and rice fields on the coastal plain nearly $350 \mathrm{~m}$ from the shore (Fig. 3.10). We observed across-shore variations in deposit thickness, grain size, sorting, skewness, and composition. The thickest deposit was $\sim 8 \mathrm{~cm}$ and is found $30 \mathrm{~m}$ from the shore. The Haiyan deposit thins rapidly landward of the shoreline and varies in thickness from 1 to $4 \mathrm{~cm}$. Except for $\mathrm{Ba} 15$ and $\mathrm{Ba} 13$, the Haiyan sediments deposited on the berm and coconut grove were coarser (very fine to medium sand), better sorted ( 1 to $2 \phi)$, and more finely skewed $(0.1$ to $0.6 \phi)$, compared to the sediments deposited on the rice fields farther inland which are silt-size, very poorly sorted $(>2 \phi)$, and coarse skewed (-0.1 to $0.1 \phi)$. With the exception of one sample, Ba8, the sediments closer to the shore also contained less organic matter at about $10 \%$ compared to the sediments on the rice fields which yielded $15 \%$ to $20 \%$ organic content. The Typhoon Haiyan deposit contains more than $10 \%$ carbonate within $\sim 200 \mathrm{~m}$ from the shore, but sediments beyond $200 \mathrm{~m}$ contain consistently low carbonate at $\sim 3 \%$ to $8 \%$. This seemingly distance-related schange in the sedimentologic character of the overwash sediments is comparable with the distance-related change in the abundance of testate amoebae and small foraminifera on the same transect (Pilarczyk et al., 2016). 


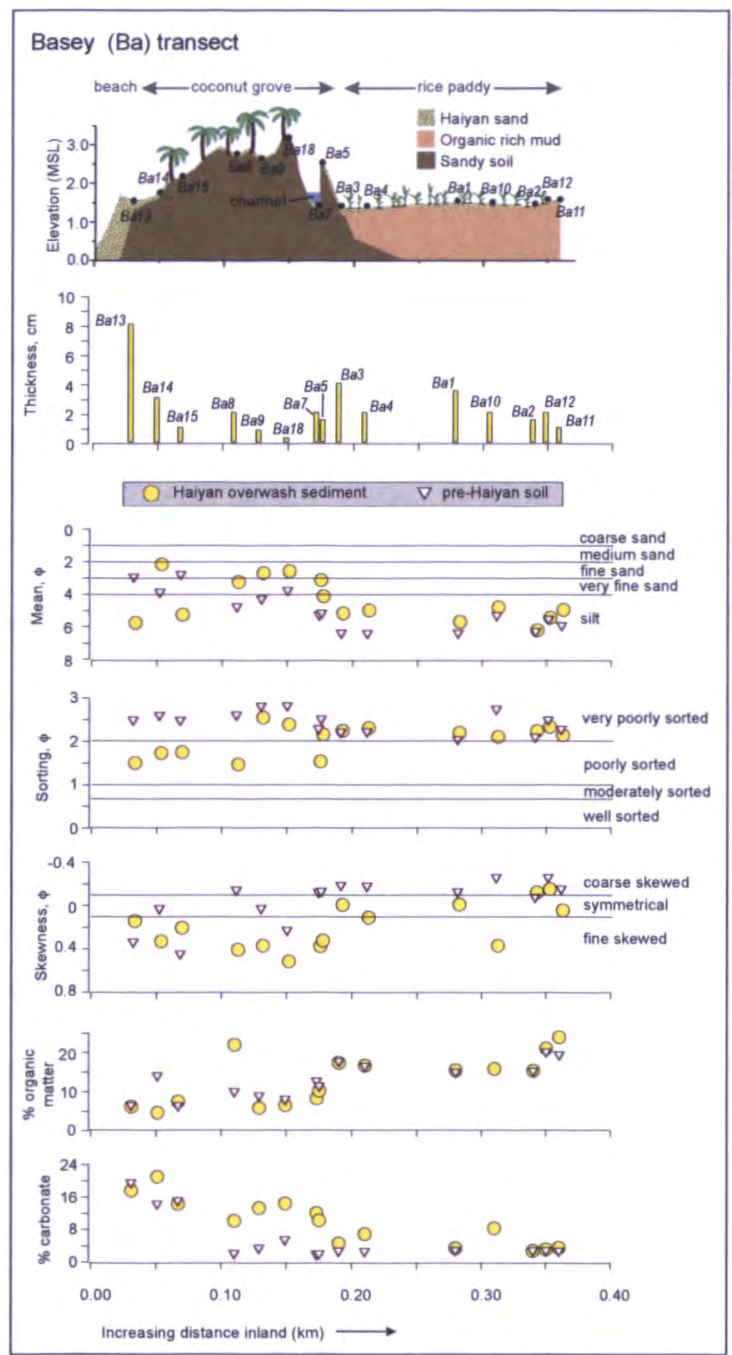

Figure 3.10. Topographic variations along the coast of Basey on the most part influenced the thickness and inland extent of the washover sediments. On the other hand, there is no direct relationship with topography and the across-shore textural and compositional variations of the Haiyan deposits. 


\subsection{Discussion}

3.6.1. Haiyan overwash sediments show clear contrasting sedimentology near the shore but show similar sedimentology inland

The Haiyan overwash sediments close to the shores in Tanauan and in Basey exhibit notable differences in sediment composition, sediment textures, and stratification. At Basey, the Typhoon Haiyan sediments are generally characterized by a massive, poorly sorted, fine sand that contained carbonate material ranging from 5 to $24 \%$, including foraminifera, and fragments of mollusks and corals (Pilarczyk et al., 2016). In contrast, the Typhoon Haiyan sediments from Tanauan are moderately to well-sorted, medium to coarse sand containing very low carbonate concentrations of $<3 \%$. Heavy minerals are relatively abundant and accumulate in layers. Thin planar laminations were also visible within the deposit. The significant disparity in the carbonate content of the Haiyan overwash sediments in Basey and that in Tanauan is indicative of the type of environment of the sediment source. Carbonate sediments are naturally readily available in the mixed carbonate-siliciclastic coast of Basey but rare in the noncarbonate, siliciclastic coast of Tanauan.

Another notable difference between the overwash sediments in Tanauan and in Basey is the landward extent. The overwash sediments along the transects Sc, So, and $\mathrm{Ma}$ in Tanauan reached greater distance inland than that of the overwash sediments along transect $\mathrm{Ba}$ in Basey. The inland penetration of overwash sediments is consistent with the inundation distance in these two sites, which is in turn mainly controlled by topography. The low-lying (1 to $2 \mathrm{~m}$ ), gently sloping 
terrain in Tanauan promoted greater inundation distance to $\sim 2 \mathrm{~km}$, and greater inland penetration of overwash sediments to $\sim 1.6 \mathrm{~km}$. The relatively irregular topography of raised carbonate platforms $(3 \mathrm{~m})$ and rice paddies on terraced slopes in Basey has limited inland inundation to $\sim 800 \mathrm{~m}$, and inland overwash sedimentation reaching to $\sim 350 \mathrm{~m}$. We can argue that given similar inundation characteristics, local topography exerts significant control on the landward extent of the deposits.

In both sites, however, the most inland Haiyan overwash sediments share commonalities in grainsize, texture, and composition. The sediments are very poorly sorted, ranging from silt to very fine sand, and contain a higher amount of organic matter ranging from 10 to $35 \%$, and lower carbonate at $<5 \%$.

The Haiyan overwash sediments occur as anomalous sand layers over muddy sediments only to a limited distance of $200 \mathrm{~m}$ (Basey) to $400 \mathrm{~m}$ (Tanauan) from the shore such as in the coconut grove and mangrove areas. Beyond $200 \mathrm{~m}$ (Basey) to $400 \mathrm{~m}$ (Tanauan), sedimentologic criteria barely discriminate overwash sediments from pre-storm sedimentary sequence. As such, the textural definition of overwash sediments as "anomalous sand layer" may not be necessarily always the case on the inland portions of inundation and overwash sedimentation (Williams, 2009). Similarly, the textural and compositional signatures inherent of the local geology, which are evident on the overwash sediments closer to the shore, seemed to be indistinct inland. 
3.6.2. Haiyan overwash sediments came from multiple sources.

The possible source of Haiyan overwash sediments was inferred from stratigraphic features (this study) and complemented with micropaleontological evidences (Pilarczyk et al., 2016). For example in Tanauan, exposed coconut roots and reexhumed mangrove soils along the coast strongly indicate extensive beach erosion. The eroded sediments from the beach were most likely transported inland and then deposited as overwash sediments. The local scouring of mangroves and the relatively high organic content of the overwash sediments found $>400 \mathrm{~m}$ from the coast may suggest that terrestrial environments are also potential sediment source of overwash sedimentation farther inland. Terrestrial source is also strongly indicated by the abundance of freshwater testate amoebae on the underlying preHaiyan soils taken on the rice fields, ponds, and grassy areas as well as on the Haiyan overwash sediments (Pilarczyk et al., 2016). In addition, Pilarczyk and others (2016) claimed that unaltered, planktic and benthic foraminifera assemblages on the Haiyan overwash sediments particularly on the Basey coast suggest contribution from offshore sediments. Foraminiferal assemblages of Hurricane Ike's overwash sediments have also pointed to multiple sediment sources including offshore, nearshore, sub- to inter-tidal, and marsh environments (Hawkes and Horton, 2012). The relative contributions of the offshore, beach, and terrestrial environments to the overwash sedimentation of Typhoon Haiyan have yet to be quantified. 
3.6.3. Sedimentary structures are consistent with a turbulent, high-velocity storm surge flow

The thick Haiyan overwash sediments display parallel laminations and overall coarsening upward trends (Figs. 3.8 \& 3.9). Planar laminations in coastal settings are primarily attributed to the repeated inundation by storm waves (e.g. Sedgwick \& Davis, 2003; Switzer \& Jones, 2008). In other instances, planar lamination or bedding in sandy sediments is indicative of the upper flow regime (UFR) conditions of a unidirectional, turbulent, high velocity flow (Cheel, 1990; Fielding, 2006). Actual field measurements of storm overwash with a 0.7m-deep surge in Assatuague Island on the U.S. Atlantic coast during Category 1 hurricanes yielded overwash flow velocities about $2 \mathrm{~ms}^{-1}$ to $3.5 \mathrm{~ms}^{-1}$ (Leatherman, 1976; Fisher and Stauble, 1977). Comparably, a 1-m deep Typhoon Haiyan flood on the coast $15 \mathrm{~km}$ to the south of Tanauan has estimated flow velocities within 3 to $4 \mathrm{~ms}^{-1}$ (Ramos et al., unpublished report). Deeper surge flood of at least $3 \mathrm{~m}$ in Tacloban yielded velocities to as high as 7 $\mathrm{ms}^{-1}$, but mainly due to channelized flows on the streets in an urban setting (Tagaki et al., 2016). The flow velocities in Tanauan could be within the range between 3 to $7 \mathrm{~ms}^{-1}$. Ramping up of surge velocity either upon the arrival of wave or backflow was claimed to produce coarsening upward grainsize trend of overwash sediments associated with similarly intense hurricanes such as Hurricane Rita and Hurricane Ike (Horton et al., 2009; Hawkes and Horton, 2012). The laminated, overall coarsening upward Haiyan overwash sediments could be the sum of all factors including repeated inundation, turbulent, and high velocity flow, which is consistent with the bore-type storm surge of 
Typhoon Haiyan. The slight fining upward trends within the overall coarsening sequence in trench MP 4 may signify local variation or flow small-scale velocity fluctuations during the inundation process (Hawkes and Horton, 2012).

3.6.4. Haiyan overwash sediments exhibit similar features with other extreme marine inundation deposits

Typhoon Haiyan's bore-like storm surge appears uncommon among the recent notable storm surges worldwide (Mikami et al., 2016). Table 3.1 shows that amongst the similarly intense modern storms, Typhoon Haiyan storm surge has exceptionally short flooding duration resulting in a steep storm surge profile (Soria et al., 2016). It is not surprising then that flow velocities of the Haiyan surge were at 3 to $7 \mathrm{~ms}^{-1}$, which are comparable to tsunami flooding in similar gently sloping coastal plains (Table 3.2). Perhaps this apparent similarity of Haiyan's storm surge to tsunami flooding has influenced overwash sedimentation such that the sedimentary features are in the most part equivocal of either storm or tsunami deposits. The sharp, depositional contact, planar stratification, coarsening upward sequence, and overall but not systematic landward fining of Haiyan overwash sediments can be seen in both storm (Table 3.1) or tsunami deposits (Tables 3.2 to 3.4). The resemblance of overwash sediments from intense storms with that from tsunamis has been consistently raised as a major concern in pre-historical reconstructions (e.g. Sugawara et al., 2008; Williams, 2009). We reaffirm this concern in so far as Haiyan overwash sediments will serve as a benchmark for sedimentological characterization of modern storm deposits in the Philippines, and particularly so because most of the Philippine coastlines are exposed to both 


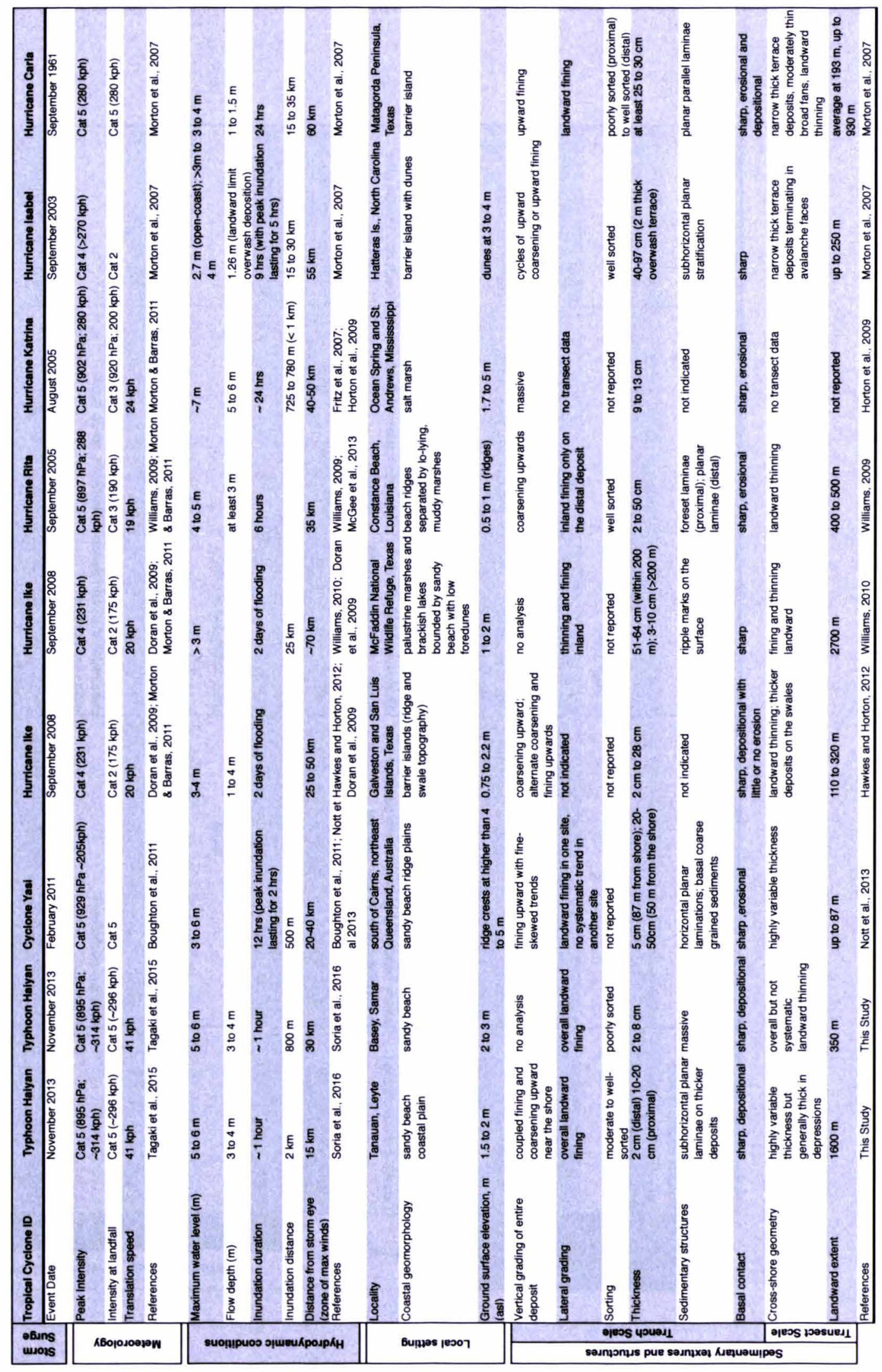




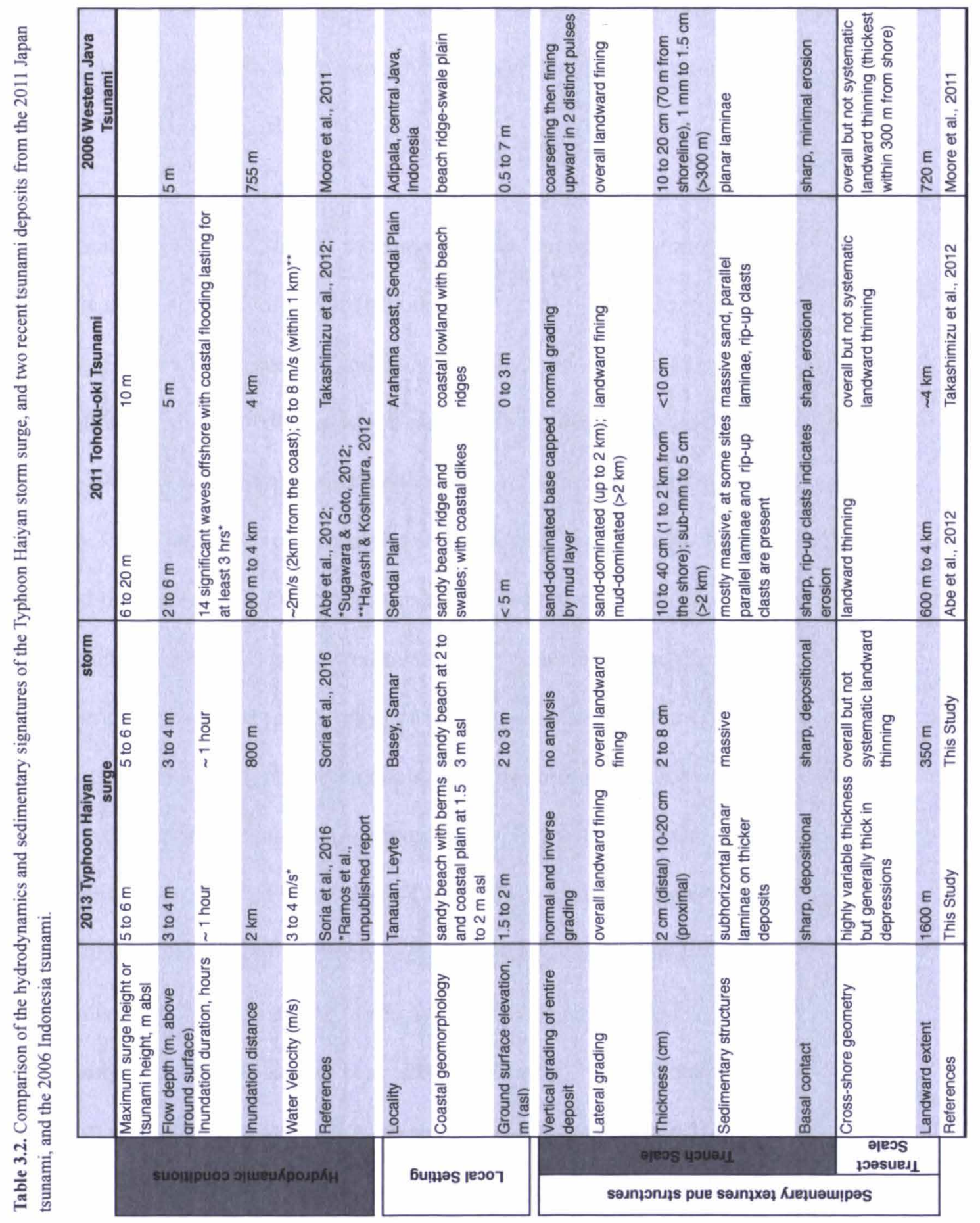




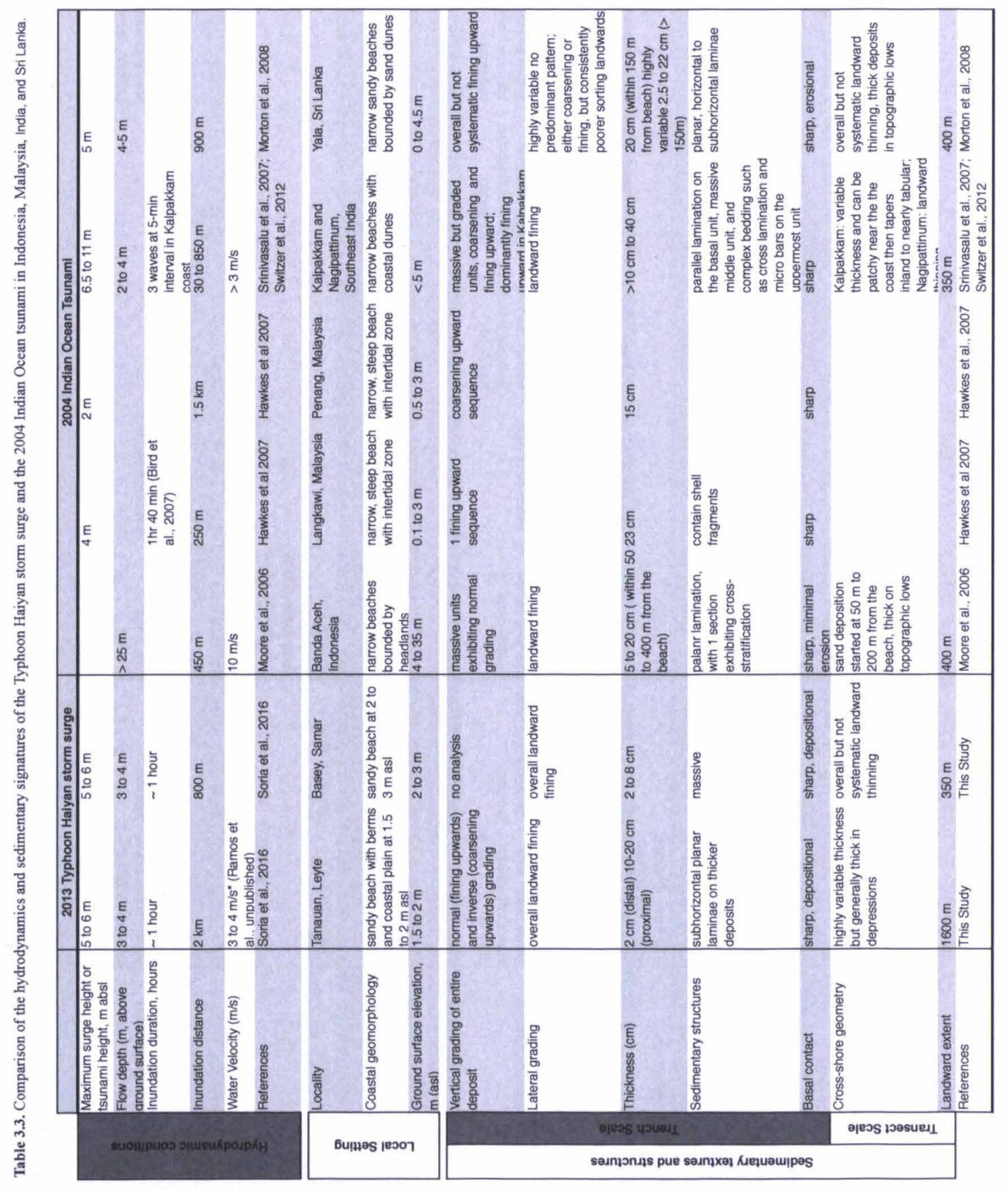




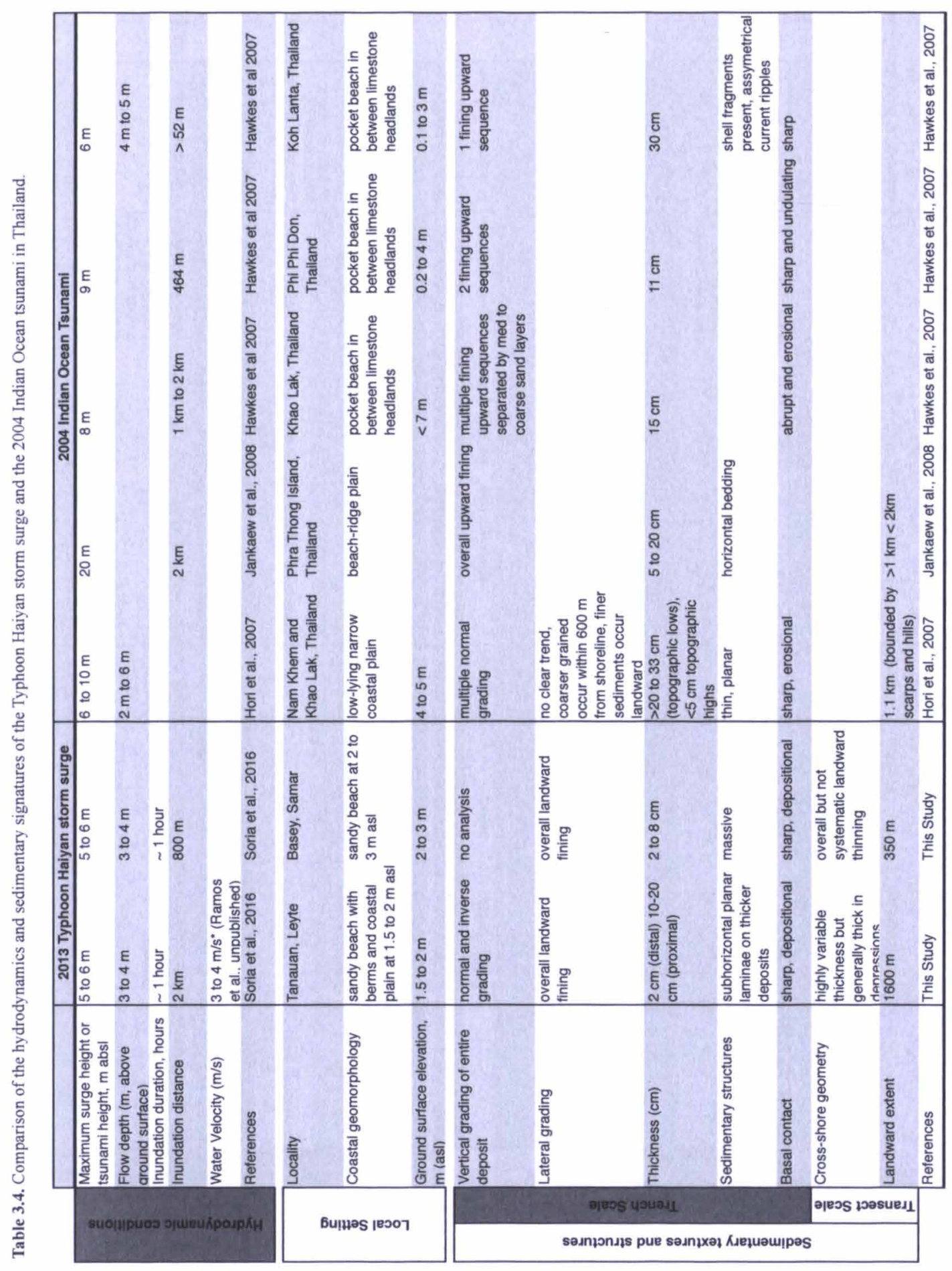


storms and tsunamis.

\subsection{Conclusion}

We described the geomorphic and sedimentologic imprints left by Typhoon Haiyan's storm surge on the shores of Leyte Gulf. We studied the overwash sedimentation across two coastal plains no more than $20 \mathrm{~km}$ apart, but representing constrasting sedimentological regimes, namely a siliciclastic coast of Tanauan and a mixed siliciclastic-carbonate coast of Basey. Despite the similar storm surge conditions in Tanauan and Basey, Typhoon Haiyan left clearly contrasting sediments underscoring the effect of local geology. On the mixed siliciclasticcarbonate coast of Basey, the Haiyan overwash sediments are carbonate-rich, poorly-sorted, silt to fine sand. In contrast, on the silicilastic coast of Tanauan, the Haiyan overwash sediments are carbonate-poor, predominantly gray, moderatelyto well-sorted, fine to coarse sand. But this contrasting sedimentology is only evident on the overwash sediments deposited within $300 \mathrm{~m}$ from the shore in Basey, and $400 \mathrm{~m}$ from the shore in Tanauan. Grainsize and compositional signatures of the most inland overwash sediments are similar in both sites and also are indistinct from the pre-Haiyan sediments. As such, the textural definition of overwash sediments as "anomalous sand layer" may not be necessarily always the case on the inland portions of inundation and overwash sedimentation.

Haiyan overwash sediments in Basey and Tanauan also illustrate that as with inundation distance, local topography also exerts significant control on the landward extent of overwash sedimentation. The low-lying flat terrain in Tanauan promoted greater inland extent of the Haiyan sediments, whereas the relatively 
irregular topography of raised carbonate platforms and rice paddies on terraced slopes in Basey limited landward overwash sedimentation.

In Tanauan, the Haiyan overwash sediments deposited within $100 \mathrm{~m}$ from the shore exhibits thin parallel to undulating laminations and overall coarsening upward trends. The laminated, overall coarsening upward Haiyan overwash sediments could be the sum of all factors including repeated inundation, turbulent, and high velocity flow, which are consistent with the bore-type storm surge of Typhoon Haiyan.

The Haiyan storm surge left overwash sediments on the shores of Basey and Tanauan that exhibit similar features to overwash sediments of comparably intense storms and storm surges elsewhere. Notably, Haiyan overwash sediments also show resemblance to recent tsunami deposits. Planar stratification, coarsening upward sequence, overall but systematic landward fining, and sharp, depositional to erosional basal contact of the Haiyan overwash sediments are equivocal as they are commonly found in both recent storm and tsunami deposits.

Overall we presented clear evidences that the interaction between hydrodynamic conditions and the local geology strongly influence inland sedimentation during extremely strong storms. However, we did not found specific sedimentological characteristics of Haiyan overwash sediments that are diagnostic from other overwash deposits. This study underscores that sedimentological characteristic alone might not yield conclusive evidence to distinguish a storm from a tsunami overwash deposit. 


\section{Acknowledgements}

This work comprises Earth Observatory of Singapore contribution no. xx. This research is supported by the National Research Foundation Singapore and the Singapore Ministry of Education under the Research Centres of Excellence initiative. We thank the local government executives Ruel Padayao (San Antonio, Basey), Jiggo Bermiso (Magay), Carmelita Villamor (Solano), Jane Mercado (Santa Cruz), and Pelagio Tecson Jr. (Mayor of Tanauan) who granted us access to the study area. Ma. Angelique Doctor assisted in taking sediment samples. Stephen Carson, Wenshu Yap, and Amanda Cheong Yee Lin assisted with laboratory analyses. We acknowledge Sorvigenaleon Ildefonso, Riovie Ramos, and Mikko Garcia for helping us gather elevation data.

\section{References}

Abe, T., Goto, K., Sugawara, D., 2012. Relationship between themaximumextent of tsunami sand and the inundation limit of the 2011 Tohoku-oki tsunami on the Sendai Plain. Sedimentary Geology 282, 142-150.

Algué, J., 1898: El baguio de Samar y Leyte, 12-13 de Octubre de 1897, Manila Observatory, 1-74.

Andrade, C., M.C. Freitas, J. Moreno, S.C. Craveiro. 2004. Stratigraphical evidence of Late Holocene barrier breaching and extreme storms in lagoonal sediments of Ria Formosa, Algarve, Portugal. Marine Geology 210, 339 362.

Aurelio, M. A, Peña, R. E., 2002. Geology and mineral resources of the Philippines, Vol. 1., Department of Environment and Natural Resources Mines and Geosciences Bureau, Philippines. 277-300.

Blott, S.J. Pye, K., 2001. GRADISTAT: a grain size distribution and statistics package for the analysis of unconsolidated sediments. Earth Surface 
Processes and Landforms 26,1237-1248. GRADISTAT Program.

Downloaded at http://www.kpal.co.uk/gradistat.html

Borrero, J. C., Synolakis, C. E., Fritz, H., 2006. Northern Sumatra Field Survey after the December 2004 Great Sumatra Earthquake and Indian Ocean Tsunami. Earthquake Spectra 22(S3), S93-S104.

Boughton, G.N., Henderson, D.J., Ginger, J.D., Holmes, J.D., Walker, G.R., Leitch, C.J., Somerville, L.R., Frye, U., Jayasinghe, N.C., Kim, P.Y., 2011. Tropical Cyclone Yasi: Structural damage to buildings. Technical Report No. 57. James Cook University pp. 1-15.

Buynevich, I.V., Fitzgerald, D.M., Van Heteren, S., 2004. Sedimentary records of intense storms in Holocene barrier sequences, Maine, USA. Marine Geology $210,135-148$.

Cheel, R. J. 1990. Horizontal lamination and the sequence of bed phases and stratification under upper-flow-regime conditions. Sedimentology 37, $517-$ 529.

Donnelly, J.P., Butler, J., Roll, S., Wengren, M., Webb, T., III, 2004. A backbarrier overwash record of intense storms from Brigantine, New Jersey. Marine Geology 210, 107-121.

Doran, K. S., Plant, N. G., Stockdon, H. F., Sallenger, A. H., Serafin, K. A., 2009, Hurricane Ike: observations of coastal change: U.S. Geological Survey Open-File Report 2009-1061.

Fielding, C. R. 2006. Upper flow regime sheets, lenses and scour fills: extending the range of architectural elements for fluvial sediment bodies. Sedimentary Geology 190, 227-240.

Fisher, J.S. and Stauble, D.K., 1978. Washover and dune interaction on a barrier island. Proceedings Coastal Zone '78 (San Francisco, California, ASCEl. pp. 1611-1618.

Folk, R.L., W.C. Ward. 1957. Brazos River bar: a study in the significance of grain size parameters. Journal of Sedimentary Petrology 27, 3-26. 
Fritz, H. M., Borrero, J. C., Synolakis, C. E., Yoo, J., 2006. 2004 Indian Ocean tsunami flow velocity measurements from survivor videos, Geophysical Research Letters 33, L24605, doi:10.1029/2006GL026784.

Fritz, H.M., Blount, C., Sokoloski, R., Singleton, J., Fuggle, A., McAdoo, B.G., Moore, A., Grass, C., Tate, B., 2007. Hurricane Katrina Storm surge distribution and field observations on the Mississippi barrier islands. Estuarine, Coastal and Shelf Sciences 74 (1-2), 12-20. doi:10.1016/j.ecss.2007.03.015.

Hawkes, A.D., Bird, M., Cowie, S., Grundy-Warr, C., Horton, B., Tan Shau Hwai, A., Law, L.. Macgregor, C., Nott, J., Eong Ong, J., Rigg, J., Robinson, R., Tan-Mullins, M., Tiong Sa, T., Zulfigar, Y., 2007. The sediments deposited by the 2004 Indian Ocean Tsunami along the Malaysia-Thailand Peninsula. Marine Geology 242, 169-190.

Hawkes, A.D., Horton, B.P., 2012. Sedimentary record of storm deposits from Hurricane Ike, Galveston and San Luis Islands, Texas. Geomorphology 171 $-172,180-189$.

Hayashi, S., Koshimura, S., 2012. Measurement of the 2011 Tohoku tsunami flow velocity by the aerial video analysis. Journal of JSCE, Series B2 (Coastal Engineering) 68, 366-370.

Heiri, O., Lotter, A.F., Lemcke, G., 2001. Loss on ignition as a method for estimating organic and carbonate content in sediments: reproducibility and comparability. Journal of Paleolimnology 25, 101-110.

Hori, K., Kuzumoto, R., Hirouchi, D., Umitsu, M., Janjirawuttikul, N., Patanakanog, B. 2007. Horizontal and vertical variation of 2004 Indian tsunami deposits: an example of two transects along the western coast of Thailand. Marine Geology 239,163-172.

Horton, B.P., Rossi, V., Hawkes, A.D., 2009. The sedimentary record of the 2005 hurricane season from Mississippi and Alabama coastlines. Quaternary International 195, 15-30.

Houser, C., Hapke, C., Hamilton, S., 2008. Controls on coastal dune morphology, shoreline erosion and barrier island response to extreme storms. 
Geomorphology 100, 223-240.

Jaffe, B.E., Borrero, J.C., Prasetya, G.S., Peters, R., McAdoo, B., Gelfenbaum, G., Morton, R., Ruggiero, P., Higman, B., Dengler, L., Hidayat, R., Kingsley, E., Kongko, W., Lukijanto, Moore A., Titov, V., Yulianto, E., 2006. Northwest Sumatra and offshore islands field survey after the December 2004 Indian Ocean Tsunami. Earthquake Spectra 22, 105-135.

Jankaew, K., Atwater, B.F., Sawai, Y., Choowong, M., Charoentitirat, T., Martin, M.E., Prendergast, A., 2008. Medieval forewarning of the 2004 Indian Ocean tsunami in Thailand. Nature 455, 1228-1231.

Leathermann, S.P., Williams, A. T., 1977. Lateral textural grading in overwash sediments. Earth Surface Processes 2, 333-341.

Leathermann, S.P., 1981. Overwash processes. Benchmark papers in Geology, Vol. 58. Hutchinson Ross Publishing Co., USA. 376 pp.

Lin, I.-I., Pun,I.-F., and Lien, C.-C., 2014. "Category-6" supertyphoon Haiyan in global warming hiatus: Contribution from subsurface ocean warming. Geophys. Res. Lett. 41, 8547-8553 doi:10.1002/2014GL061281.

Liu, K-b., Fearn, M. L., 1993. Lake-sediment record of late Holocene hurricane activities from coastal Alabama. Geology 21, 793-796.

Mas, E., J. Bricker, S. Kure, B. Adriano, C. Yi, A. Suppasri, and S. Koshimura, 2015: Field survey report and satellite image interpretation of the 2013 Super Typhoon Haiyan in the Philippines. Nat. Hazards Earth Syst. Sci. 15, 805816, doi:10.5194/nhess-15-805-2015.

McGee, B. D., Goree, B. B., Tollett, R. W., Woodward, B. K., and Kress, W. H., 2013. Hurricane Rita Surge Data, Southwestern Louisiana and Southeastern Texas, September to November 2005. LC11. U.S. Geological Survey. http://pubs.usgs.gov/ds/2006/220/index.htm\#elevsurveys accessed on 6 May 2016.

Mikami, T., Shibayama, T., Takagi, H., Matsumaru, R., Esteban, M., Thao, N.D., De Leon, M., Valenzuela, V.P., Oyama, T., Nakamura, R., Kumagai, K., Li, S., 2016. Storm surge heights and damage caused by the 2013 Typhoon Haiyan slong the Leyte Gulf coast. Coastal Engineering Journal 58 (1), doi: 


\section{$10.1142 / \mathrm{S} 0578563416400052$}

Monecke, K., Finger, W., Klarer, D., Kongko, W., McAdoo, B.G., Moore, A.L., Sudrajat, S.U., 2008. A 1,000-year sediment record of tsunami recurrence in northern Sumatra. Nature 455, 1232-1234.

Moore A., Goff, J., Mc Adoo, B. G., Fritz, H. M., Guzman, A., Kalligeris, N., Kalsum, K., Susanto, A., Suteja, D., Synolakis, C. E., 2011. Sedimentary deposits from the 17 July 2006 Western Java Tsunami, Indonesia: Use of grain size analyses to assess tsunami flow depth, speed, and traction carpet characteristics. Pure Appl. Geophys. 168, 1951-1961.

Moore, A., Nishimura, Y., Gelfenbaum, G., Kamataki, T.,Triyono, R., 2006, Sedimentary deposits of the 26 December 2004 tsunami on the northwest coast of Aceh, Indonesia: Earth, Planets, and Space 58, 253-258.

Morton, R.A., Barras, J.A., 2011. Hurricane impacts on coastal wetlands: a halfcentury record of stormgenerated features from southern Louisiana. Journal of Coastal Research 27(6A), 27-43.

Morton, R.A., Gelfenbaum, G. and Jaffe, B.E. 2007: Physical criteria for distinguishing sandy tsunami and storm deposits using modern examples. Sedimentary Geology 200, 184-207.

Morton, R.A., Goff, J.R., Nichol, S.L., 2008. Hydrodynamic implications of textural trends in sand deposits of the 2004 tsunami in Sri Lanka. Sedimentary Geology 207, 56-64.

Morton, R.A., Sallenger, A.H., 2003. Morphological impacts of extreme storms on sandy beaches and barriers. Journal of Coastal Research 19, 560-573.

Nott, J., Chague-Goff, C., Goff, J., Sloss, C., Riggs, N., 2013. Anatomy of sand beach ridges: Evidence from severe Tropical Cyclone Yasi and its predecessors, northeast Queensland, Australia, Journal of Geophysysical Research: Earth Surface 118, 1710-1719, doi:10.1002/jgrf.20122.

Nott, J., Hubbert, G., 2005. Comparisons between topographically surveyed debris lines and modelled inundation levels from severe tropical cyclones Vance and Chris, and their geomorphic impact on the sand coast. Australian Meteorological Magazine 54,187-196. 
Otvos, E.G., 2011. Hurricane signatures and landforms-toward improved interpretations and global storm climate chronology. Sedimentary Geology $239,10-22$.

Pilarczyk, J.E., Horton, B. P., Soria, J. L. A., Switzer, A. D., Siringan, F., Fritz, H. M., Khan, N. S., Ildefonso, S., Ramos, R., Doctor, A. A., Garcia, M. L., 2016. Micropaleontology of the 2013 Typhoon Haiyan overwash sediments from the Leyte Gulf, Philippines. Sedimentary Geology 339, 104-114.

Permanent Service on Mean Sea Level, PMSL accessed on 16 February 2016. http://www.psmsl.org/data/obtaining/stations/664.php.

Sedgwick, P. E., Davis. R. A. Jr., 2003. Stratigraphy of washover deposits in Florida: implications for recognition in the stratigraphic record. Marine Geology 200, 31-48.

Soria, J.L.A., Switzer, A.D., Villanoy, C.L., Fritz, H.M., Bilgera, P.H.T., Cabrera, O.C., Siringan, F.P., Yacat-Sta. Maria, Y., Ramos, R.D., Fernandez, I.Q., 2016. Repeat storm surge disasters of Typhoon Haiyan and its 1897 predecessor in the Philippines. Bulletin of the American Meteorological Society 97(1), 31-48. doi, 10.1175/BAMS-D-14-00245.1

Srinivasalu, S., Thangadurai, N., Switzer, A. D., Ram Mohan, V., Ayyamperumal, T. 2007. Erosion and sedimentation in Kalpakkam (N Tamil Nadu, India) from the 26th December 2004 tsunami. Marine Geology 240, 65-75.

Suerte, L.O., Yumul, G.P.Jr., Tamayo, R.A.Jr., Dimalanta, C.B., Zhou, M.-F., Maury, R.C., Polvé, M., Balce, C.L., 2005. Geology, Geochemistry and U$\mathrm{Pb}$ SHRIMP age of the Tacloban Ophiolite Complex, Leyte (Central Philippines): Implications for the existence and extent of the ProtoPhilippine Sea Plate. Resource Geology 55(3), 207-216.

Sugawara, D., Goto, K., 2012. Numerical modeling of the 2011 Tohoku-oki tsunami in the offshore and onshore of Sendai Plain, Japan. Sedimentary Geology 282, 110-123.

Sugawara, D., Minoura, K., Imamura, F., Tsunamis and tsunami sedimentology. In: Shiki, T. et al. (Eds.) Tsunamiites-features and implications. Elsevier B.V.,pp. 9-49. 
Switzer, A.D., B.G. Jones, 2008. Set-up, deposition and sedimentary characteristics of two storm overwash deposits, Abrahams Bosom Beach, eastern Australia. Journal of Coastal Research 24-1A, 189-200.

Switzer, A.D., and J. Pile, 2015. Grain size analysis. In: Shennan, I. et al. (Eds.) Handbook of Sea-Level Research. John Wiley \& Sons, Ltd., pp. 331-346.

Switzer, A. D., S. Srinivasalu, N. Thangadurai, and V. Ram Mohan, 2012. Bedding structures in Indian tsunami deposits that provide clues to the dynamics of tsunami inundation. Geological Society, London, Special Publications 361,61-77. doi: 10.1144/SP361.6

Tajima, Y., Yasuda, T., Pacheco, B. M., Cruz, E. C., Kawasaki, K., Nobuoka, H., Miyamoto, M., Asano, Y., Arikawa, T., Ortigas, N. M., Aquino, R., Mata, W., Valdez, J. \& Briones, F., 2014: Initial report of JSCE-PICE joint survey on the storm surge disaster caused by Typhoon Haiyan. Coastal Engineering Journal 56, 1450006, doi:10.1142/S0578563414500065.

Takagi, H., Esteban, M., 2016. Statistics of tropical cyclone landfalls in the Philippines:unusual characteristics of 2013 Typhoon Haiyan. Natural Hazards 80, 211-222. doi 10.1007/s11069-015-1965-6.

Takagi, H., Esteban, M., Shibayama, T., Mikami, T., Matsumaru, R., De Leon, M., Thao, N.D., Oyama, T., Nakamura, R., 2015. Track analysis, simulation, and field survey of the 2013 Typhoon Haiyan storm surge. Journal of Flood Risk Management. doi: 10.1111/jfr3.12136.

Takagi, H., Li, S., de Leon, M., , Esteban, M., Mikami, T., Matsumaru, R., Shibayama, T., Nakamura, R., 2016. Storm surge and evacuation in urban areas during the peak of a storm. Coastal Engineering 108, 1-9.

Takashimizu, Y., Urabe, A., Suzuki, K., Sato, Y., 2012. Deposition by the 2011 Tohoku-oki tsunami on coastal lowland controlled by beach ridges near Sendai Japan. Sedimentary Geology 282, 124-141.

Williams H.F.L., 2009. Stratigraphy, sedimentology, and microfossil content of Hurricane Rita storm surge deposits in southwest Louisiana. Journal of Coastal Research 25(4), 1041-1051. 
Williams, H. F. L., 2010. Storm surge deposition by Hurricane Ike on the McFaddin National Wildlife Refuge, Texas: Implications for paleotempestology studies. Journal of Foraminiferal Research 40(3), 210 219.

Williams, H.F.L., Flanagan, W.M., 2009. Contribution of Hurricane Rita storm surge deposition to long-term sedimentation in Louisiana coastal woodlands and marshes. Journal of Coastal Research, Specail Issue 56, 1671-1675. 


\section{Chapter 4}

\section{Typhoon Haiyan storm surge carried two distinct}

\section{sediment assemblages on the carbonate coast of Hernani,}

\section{Samar, central Philippines}

Janneli Lea A. Soria ${ }^{1}$, Adam D. Switzer ${ }^{1,2}$, Linlin $\mathrm{Li}^{2}$, Michelle Manglicmot ${ }^{3}$, Adonis Gallentes ${ }^{3}$, Fernando Siringan ${ }^{3}$, A.Y. Annie Lau ${ }^{4}$, Amanda Cheong Yee Lin', Tracy Koh Wei Ling ${ }^{1}$,

${ }^{1}$ Asian School of the Environment, Nanyang Technological University, Singapore 639798

${ }^{2}$ Earth Observatory of Singapore, Nanyang Technological University, Singapore 639798

${ }^{3}$ Marine Science Institute, University of the Philippines, Diliman, Quezon City, Philippines 1101

${ }^{4}$ School of Geography Planning and Environmental Management, University of Queensland, Brisbane, Australia 4072

Keywords: Haiyan, storm wave, carbonate coast, reef boulders, TsuSedMod 


\section{Contributions}

Lea is the primary author, and with Adam, and Fernando conceptualized the idea, identified appropriate methods, and contributed to its formality and development. Lea set-up the laboratory protocol for sample and data treatment based on established methods on sedimentology, supervised student interns conducting grainsize analysis, interpreted and synthesized data, and wrote the paper. Linlin carried out sediment transport modeling using TsuSedMod, and contributed the data to this study. Michelle and Adonis helped in collecting data on the field and discussed data analysis based on other boulder sites in the Philippines. Annie provided a comprehensive overview on coral reef boulder studies and provided the spreadsheet for automated boulder data analysis. Amanda and Tracy worked closely with Lea on the boulder data analysis and grainsize analysis as part of the undergraduate student internship program of the Asian School of the Environment.

Janneli Lea A. Soria: $50 \%$

Adam D. Switzer: $15 \%$

Linlin Li: 7\%

Michelle Manglicmot: $6 \%$

Adonis Gallentes: $6 \%$

Fernando Siringan: 5\%

A.Y. Annie Lau: $4 \%$

Amanda Cheong Yee Lin: 4\%

Tracy Koh Wei Ling: 3\% 


\section{Abstract}

A combination of wave set-up and infragravity waves steepened and accentuated the storm surge during Typhoon Haiyan in November 2013 resulting in a tsunamilike wave with surge heights of $7 \mathrm{~m}$ and flow velocities reaching $5 \mathrm{~ms}^{-1}$ on the open-sea coastal plain near Hernani. This study investigates two distinct sediment assemblages left behind by the coastal flooding associated with this surge. The first assemblage consists of numerous coastal boulders that now occupy the reef flat, and the second pertains to a laterally extensive sand sheet that blanketed the coconut groves and rice fields of the coastal plain up to $\sim 300 \mathrm{~m}$ inland. Boulder transport models indicate that minimum flow velocities ranging from 2 to $5 \mathrm{~ms}^{-1}$ were required to initially transport the boulders. Landward of the boulder field and behind a mangrove stand completely defoliated by the Haiyan surge we identify and characterize a coarse carbonate sand sheet on the coastal plain. The sandsheet represents the onshore sediment record of Haiyan and is up to $10 \mathrm{~cm}$ thick. It starts $\sim 10 \mathrm{~m}$ inland of the beach representing the current shoreline and extends up to $300 \mathrm{~m}$ inland. The sand drapes the landscape, thinning and becoming patchy as it spreads and fines to a silty sand only a few $\mathrm{mm}$ thick at its landward extent. Preliminary inverse modeling using the grainsize distribution and thickness of the sandsheet on TsuSedMod yielded maximum flow velocities exceeding $4 \mathrm{~ms}^{-1}$ on the coastal plain. The sediment-derived flow velocity estimates are remarkably consistent with values reconstructed previously from video recordings, and wave modeling. Collectively, the bore-like Haiyan storm surge had travelled across the wide reef flat and inundated the coast with sustained high flow velocity causing significant damage to coastal vegetation and coastal structures along its path. 


\subsection{Introduction}

High waves and storm tides associated with tropical and extratropical cyclones can strongly affect coastal morphology and ecosystems. Tropical cyclones commonly generate large ocean waves that when combined with storm surges have the demonstrated capability of causing significant geomorphic change at the coast (e.g. Nott and Hubbert, 2005; Fritz et al., 2009; Etienne and Terry, 2012). In tropical environments such impacts are commonly recorded by the large-scale erosion of beaches (e.g. Nott and Hubbert, 2005), damage to coastal vegetation including mangrove systems (e.g. Primavera et al., in press) and modifications to reef and coastal plain sedimentation (e.g. Scheffers and Scheffers, 2006; Etienne and Terry, 2012; Atwater et al., 2014). In carbonate reef systems the impacts of such events are commonly observed in the formation of coral rubble ridges (e.g. Spiske and Halley, 2014; Reyes et al., 2015), and the transport and deposition of conspicuous boulders mostly reefal clasts onto the reef flat (e.g. Etienne and Terry, 2012; May et al., 2015; Kennedy et al., 2016).

Typhoon Haiyan impacted several carbonate coastlines across different Philippine islands as it made its path across the archipelago. One such coast is the open-sea coast of Eastern Samar and it is here that Roeber and Bricker (2015) demonstrated that the combined wave-breaking setup and infragravity waves caused an elevated, high-velocity, bore-like storm surge flooding in Hernani (Fig. 4.1). The unusual flooding characteristics of the "tsunami-like" bore contrast with the dominantly wind-induced setup on the coasts surrounding the shallow waters of Leyte Gulf including Tacloban City (Soria et al., 2016) and the combined wave-breaking setup and infragravity waves seem to be unique on the open-sea, fringing reef 
a
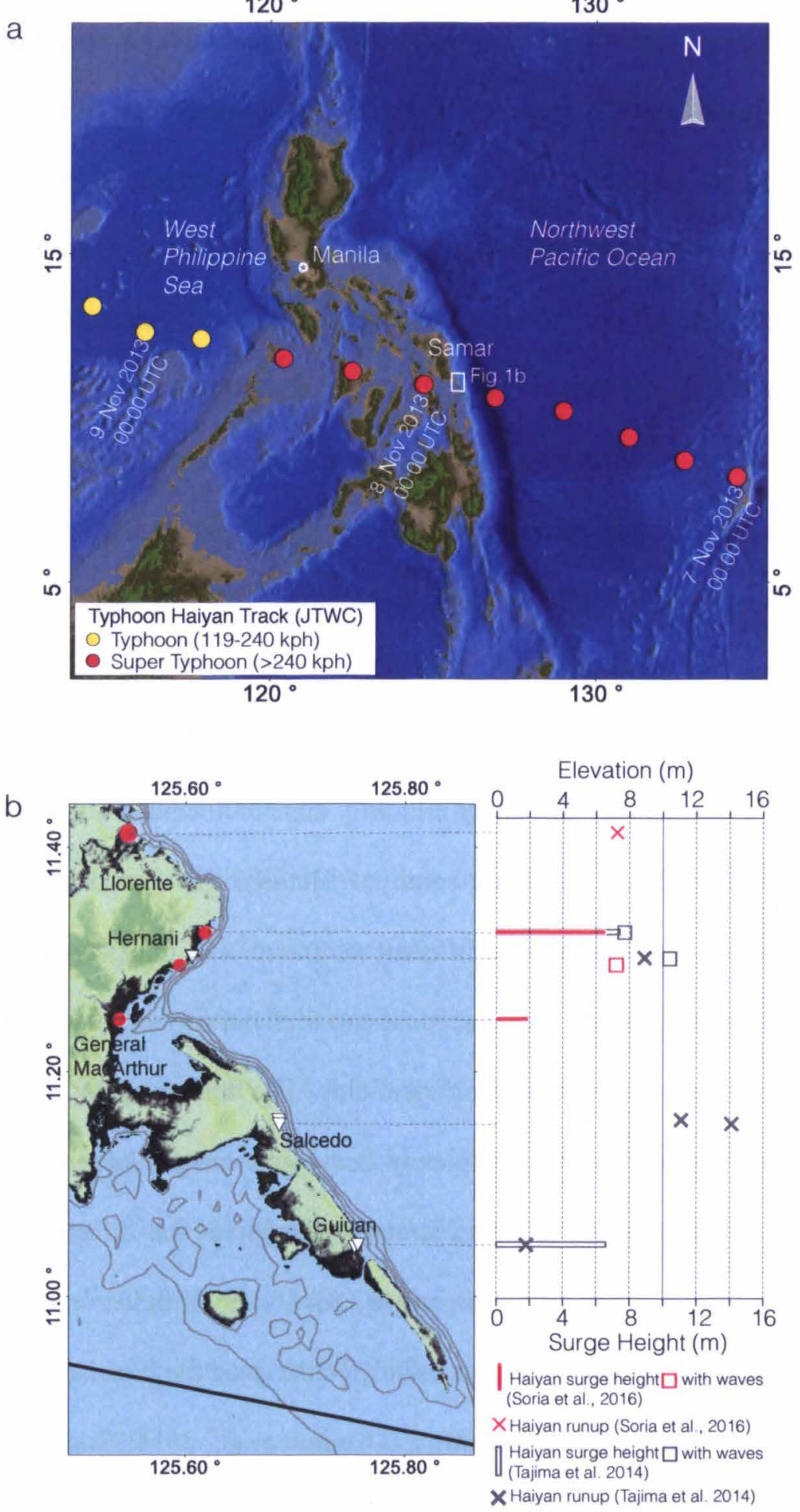

Figure 4.1. Typhoon Haiyan showing the track and intensity while crossing central Philippines, and the measured storm surge and runup heights (b) along the eastern coast of Samar Island (modified from Soria et al., 2016). 
coast (Roeber and Bricker, 2015). Notably, similar flooding characteristics were recognized in Guiuan, $\sim 30 \mathrm{~km}$ southeast of Hernani and more proximal to Haiyan's landfall site (Kennedy et al., 2016). The most notable geomorphic and sedimentologic impacts of the extreme inundation of Haiyan on the carbonate Philippine coastlines were the conspicuous dislocated boulders now emplaced at elevations ranging from 2 to $10 \mathrm{~m}$ and weighing up to $30 \mathrm{t}$ in Guiuan (Kennedy et al., 2016) and up to $180 \mathrm{t}$ in Hernani (May et al., 2015). In comparison, moderate flooding of the carbonate coasts on the more interior Philippine islands during Haiyan has formed conspicuous coral rubble ridge about 10 to $20 \mathrm{~m}$ wide and $\sim 0.5$ m high (Reyes et al., 2015; Brill et al., 2016).

Recognizing the highly variable coastal setting and potentially different exposure to Haiyan's storm surge, this study primarily aims to document the sedimentologic impact of Haiyan on the coast south of Hernani. This area offers a unique opportunity to investigate two different sediment assemblages along the same transect, from the boulders emplaced on the reef flat to the sand sheet deposited inland in a coconut forest and on ricefields. The transect also crosses a small mangrove forest which was completely defoliated and partially uprooted during typhoon Haiyan. Hernani is also a strategic site given that different independent methods including actual video recording, post-typhoon field surveys, and storm surge modeling consistently and accurately constrained the inundation depths, flow velocities, and flooding mechanism (e.g. Tajima et al., 2014; Bricker et al., 2014, Roeber and Bricker, 2015; Soria et al., 2016). 
With our dataset we can 1) test the boulder-derived flow velocity estimates in this study against the flow velocity estimated using forward wave modeling; 2) apply an inverse sediment transport model TsuSedMod to the sand deposits; 3) compare the velocity measurements from the reef flat, coconut forest and rice fields; and 4) assess whether the sediment information provides insights into whether the mangrove forest that separates the reef and coastal plain or the hydraulic jump associated with a raised ridge on which the road sat pre Haiyan had any effect on overland velocity.

\subsection{Typhoon Haiyan and storm surge}

Typhoon Haiyan was an extremely intense and fast moving typhoon and one of the most intense in history (Lin et al., 2014; Tagaki et al., 2016). Typhoon Haiyan severely affected more than 16 million people, killed more than 6000 and destroyed more than 1.1 million dwellings in the central Philippines (Lagmay et al., 2015; Soria et al., 2016). The true intensity of Haiyan remains debatable. The Dvorak-based intensity scale indicates that Typhoon Haiyan reached peak intensity of maximum wind speed at $\sim 314 \mathrm{kph}$ near landfall, far exceeding the upper limits of Saffir Simpson Hurricane Scale (Lin et al., 2014). In contrast, local Doppler radar data from the Philippine Atmospheric Geophysical and Astronomical Services Administration (PAGASA) in Guiuan registered a much lower intensity with minimum central pressure of $910 \mathrm{hPa}$, and winds at $160 \mathrm{~km} \mathrm{~h}^{-1}$ with gusts of $\sim 195 \mathrm{~km} \mathrm{~h}^{-1}$ at 2000 on 7 November UTC (0400 on 8 November Philippine Time, PHT), just before Haiyan's landfall (Paciente, 2014). Extreme winds destroyed the Guiuan Doppler radar station about 16 minutes later. Haiyan crossed the small islands off the southeast tip of Samar Island, near Guiuan at 2040 on 7 November 
UTC (0440 PHT 8 November). Haiyan then continued westwards with minimal dissipation and then made five subsequent landfalls as it crossed the central Philippines (NDRRMC 2013b).

On the more open and exposed Pacific coastline at Hernani, some $45 \mathrm{~km}$ north of the typhoon track, significant storm-wave contributions resulted in high water marks exceeding $7 \mathrm{~m}$ (Fig. 4.1b). Further amplification by the wave runup on steep slopes such as near Guiuan resulted in a maximum runup height of $14 \mathrm{~m}$ (Tajima et al. 2014). But on a relatively sheltered coast such as General MacArthur (Fig 4.1), surge height was recorded at its lowest of about $2 \mathrm{~m}$ (Soria et al., 2016). The fringing coral reefs located $3 \mathrm{~km}$ offshore and the narrow bottleneck entrance of the bay likely attenuated storm waves in this site, as such, the measurement is most likely dominated by the smaller atmospheric storm-surge component. Using the surge height in General Macarthur as a baseline we can assume that the wave setup and infragravity waves could have contributed to the super-elevation of coastal flooding by as much as $5 \mathrm{~m}$.

\subsection{Study Area}

The town of Hernani is situated on a narrow coastal plain at about $3 \mathrm{~m}$ above mean sea level (Roeber and Bricker, 2015), underlain by late Pliocene to Pleistocene reefal limestone (Aurelio and Peña, 2002). Mangroves and a fringing reef shelter the shore against normal fair weather waves. The mangrove area is $\sim 100 \mathrm{~m}$ to 300 $\mathrm{m}$ wide natural stands of Sonneratia alba, Avicennia marina, Bruguiera gymnorrhiza, Aegiceras floridum and Aegiceras corniculatum (Primavera et al., 2016). Seaward of the mangrove extends a reef flat $\sim 400$ to $500 \mathrm{~m}$ wide. A narrow 
inlet divides the reef flat into a northeastern and a southwestern segment. The reef edge is at $\sim 1 \mathrm{~m}$ below mean sea level ( $\mathrm{msl}$ ), but just a few hundred meters offshore the seafloor rapidly drops to $50 \mathrm{~m}$ (Roeber and Bricker, 2015). The coast is microtidal and exposed to Pacific Ocean swell systems (Maeda et al., 2004; May et al., 2015).

Hernani sustained significant damage from Typhoon Haiyan. A satellite image taken 5 days after landfall shows the extent of damage to properties and coastal vegetation within the inundation limit (Fig. 4.2b). Sand surfaces extend landwards from the beach indicating inland deposition. Seven months following Typhoon Haiyan, coastal vegetation has significantly recovered, except for the mangrove stands (Fig. 4.2c).

\subsection{Methods}

\subsubsection{Post-typhoon Haiyan survey}

Our field surveys were conducted in May and June 2014 on a transect about 1.5 $\mathrm{km}$ south of Hernani, through a village called Carmen. The transect is about $1-\mathrm{km}$ long from the reef edge through the coconut groves and the rice paddies inland, through to the back of a limestone ridge (Fig. 4.3). The reef edge is defined in this study as the landward limit of the spurs and grooves exposed during low tide at the time of survey, which closely corresponds to the seaward limit of wave refraction on satellite imagery. Reef flat and land surface elevations were measured using two units of Ashtech Promark 2 Survey System ${ }^{\mathrm{TM}}$ on a base/rover configuration for differential global positioning system (dgps). Raw elevation values were postprocessed with GNSS Solutions software for vertical accuracy. A local GPS 

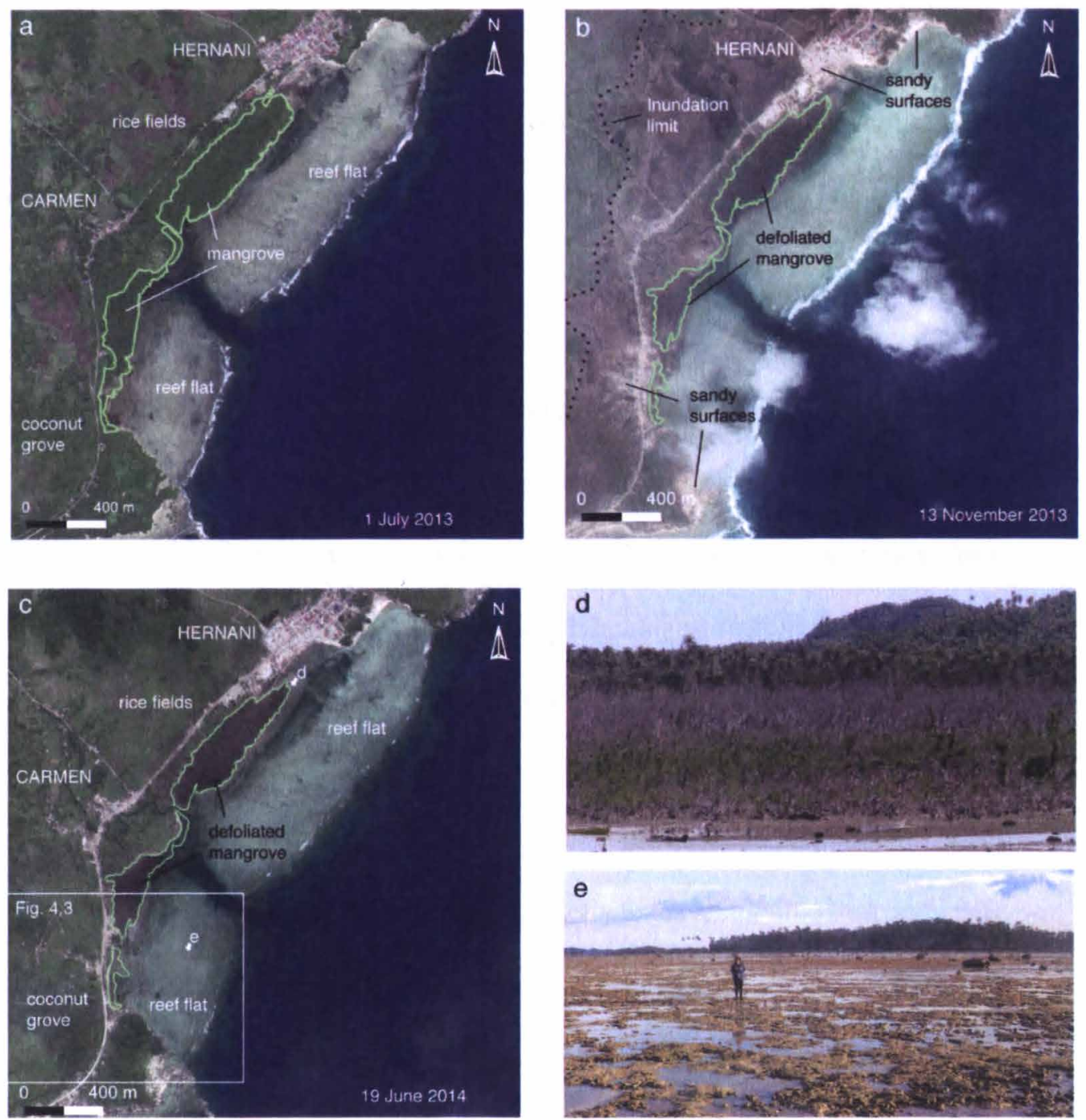

Figure 4.2. Pre- and post-typhoon Haiyan satellite images and photos of Hernani town. The satellite images were purchased from Digital Globe through the Centre of Remote Imaging, Sensing and Processing (CRISP).

a) Open-sea coast of Hernani is fringed by natural barriers including a prominent reef-flat, and intact mangrove stands.

b) Post-typhoon Haiyan image showing the extent of damage to properties, defoliated mangroves, and damage to coastal vegetation within the inundation limit.

c) Recovery condition in Hernani seven months after typhoon Haiyan's landfall. Coastal vegetation has recovered except for the mangrove stands. Enclosed in the rectangle is the study area.

d) Defoliated mangoves south of Hernani showing initial stages of recovery in June 2014 .

e) The reef flat south of Hernani is strewn with boulders after Typhoon Haiyan. 
a
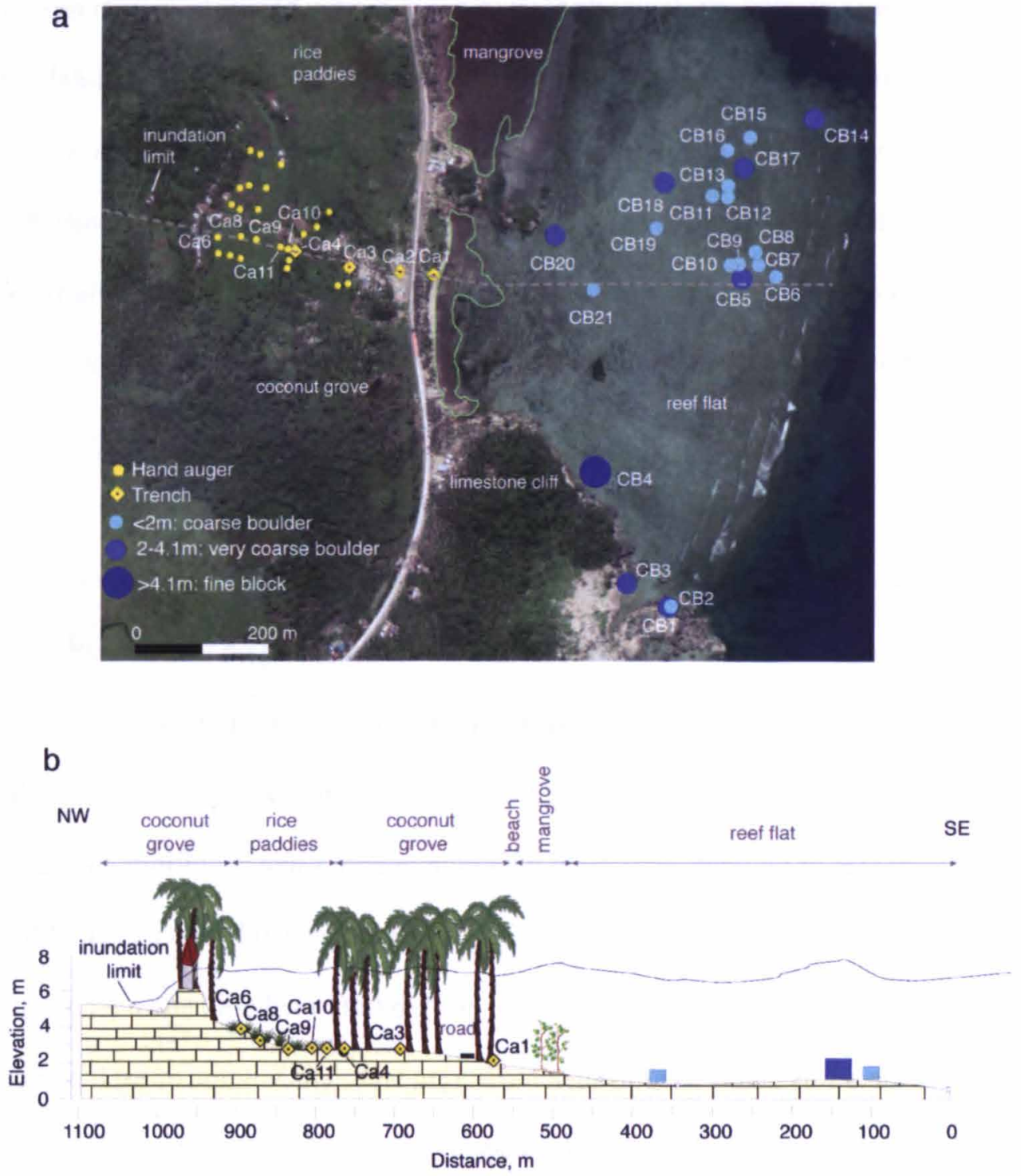

Figure 4.3. Detailed map of the study area showing the samples taken across different coastal environments south of Hernani (a). The actual inundation limit verified by witnesses accounts is $\sim 100 \mathrm{~m}$ inland of the satellite-image derived inundation limit. Gray dashed line indicates the transect for the topographic profile and the samples taken onland (b). 
station PIMO established by IGS (International GNSS Service) was used as a reference alongside tide level observations in the field for local datum topographic adjustment. In fair weather conditions, the reef flat is within the intertidal zone with water depths not exceeding $1 \mathrm{~m}$ at high tide. Typhoon Haiyan, however, has completely inundated the reef flat and the adjoining coastal plain. Residents of the houses built on top of a limestone ridge $\sim 6 \mathrm{~m}$ above $\mathrm{msl}$ attest overland flooding on the ridge by $1.5 \mathrm{~m}$.

\subsubsection{Reef flat boulders}

The extreme flooding during Typhoon Haiyan has emplaced boulders on the reef flat south of Hernani. However, only the boulders found on the southwestern segment of the reef flat were mapped in this study. Coastal boulders with intermediate axis $>1 \mathrm{~m}$ were considered because this size criterion falls within the usual size of boulders associated with high-energy wave conditions such as storm and tsunami (Switzer and Burston, 2010; Paris et al., 2011; Terry et al., 2013). The dimension along three axes a (longest), b (intermediate), and c (shortest) of 21 boulders was determined using a measuring tape. The volume of each boulder was estimated based on the geometric shape classified as triangular, ellipsoidal, and rectangular (Lau, 2015; Terry et al., 2013). Most of the boulders closely approximate but do not perfectly fit a rectangular shape. Previous studies highlight that the conventional equation $\mathrm{V}_{\mathrm{abc}}=\mathrm{a}^{*} \mathrm{~b}^{*} \mathrm{c}$ for rectangular boulders usually overestimates by as much as 50 to $60 \%$ the actual volume and weight of limestone (Engel and May, 2012; May et al, 2015). The maximum value of 0.6 was factored in the conventional equation to minimize overestimation of boulder volume and mass. The bulk density of $2.4 \mathrm{gcm}^{-3}$ calculated by May et al. (2015) from the reef 
boulders located $5 \mathrm{~km}$ north of Hernani was adopted to determine the weight. A lower bulk density value of $1.99 \mathrm{gcm}^{-3}$ derived from other Philippine coral boulders (Siringan et al., unpublished) was also considered.

The boulder dimensions were used as inputs on established boulder transport equations of Nandasena et al. (2011) to infer minimum flow velocity conditions for varying mode of transport initiation such as sliding, rolling, and lifting. All these processes can occur on a reef boulder in either a subaerial or submerged setting. The required minimum velocity for each condition is:

Sliding: $u^{2} \geq \frac{2\left(\frac{\rho_{s}}{\rho_{w}}-1\right) g c\left(\mu_{s} \cos \theta+\sin \theta\right)}{c_{d}\left(\frac{c}{b}\right)+\mu_{s} c_{l}}$

Rolling: $u^{2} \geq \frac{2\left(\frac{\rho_{s}}{\rho_{w}}-1\right) g c\left(\cos \theta+\left(\frac{c}{b}\right) \sin \theta\right)}{c_{d}\left(\frac{c^{2}}{b^{2}}\right)+c_{l}}$

Lifting $: u^{2} \geq \frac{2\left(\frac{\rho_{s}}{\rho_{w}}-1\right) g c \cos \theta}{C_{l}}$

where $\rho_{s}=$ density of the boulder $=2.4 \mathrm{gcm}^{-3} ; \rho_{w}=$ density of sea water $=$ $1.02 \mathrm{gcm}^{-3} ; \mathrm{g}=$ gravitational acceleration $=9.81 \mathrm{~ms}^{-1} ; \mathrm{c}=$ shortest axis; $\mathrm{b}=$ intermediate axis; $u_{s}=$ coefficient of static friction $=0.5 ; \theta=$ angle of the bed slope $=0 ; C_{d}=$ coefficient of drag $=1.95 ; C_{l}=$ coefficient of lift $=0.178$.

In each scenario the flow will generate drag, inertia, and lift forces to initiate the movement of a boulder that is assumed to be already detached from the reef. But, for a boulder, which is originally attached to the reef with only the top surface 
exposed, lift is the only force that can possibly initiate movement expressed by the equation:

Lifting (Joint-bounded): $u^{2} \geq \frac{2\left(\frac{\rho_{S}}{\rho_{w}}-1\right) g c\left(\cos \theta+u_{s} \sin \theta\right)}{C_{l}}$

In the case of a reef flat with a bed slope $\theta$ equal to $0^{\circ}$ such as in our study area, the term $\sin \theta$ is equivalent to 0 . As such, the minimum flow velocity required to initiate boulder movement by lifting is the same for both of the subareal and submerged non-obstructed (Eqn 3) and joint-bounded (Eqn 4) scenarios.

\subsubsection{Onshore carbonate sediments}

Inland transport and deposition of sediments from Typhoon Haiyan were also mapped extending to $>300 \mathrm{~m}$ from the beach. A large diameter $(50 \mathrm{~mm})$ hand auger was used for the inventory of Haiyan sediment thickness on the coconut grove and rice paddies (Fig. 4.3). At all sites, one sediment sample from the Haiyan deposit on the surface and one sample from the underlying soil were collected for sediment grainsize, and sediment composition analyses. Shallow trenches were subsequently excavated to expose thicker accumulations of Haiyan sediments on the coconut grove that were sampled at $1 \mathrm{~cm}$ intervals.

The relative amounts of the organic and carbonate components were determined following the loss-on-ignition method (Heiri et al., 2001). About $1 \mathrm{~g}$ to $2 \mathrm{~g}$ of sediment from each sample was burned on a muffle furnace at $550^{\circ} \mathrm{C}$ for 4 hours and the weight loss corresponded to the organic content. Carbonate content, in contrast, was determined using two different methods depending on the grainsize of the sediments. For muddy sediments, loss-on ignition method 
was continued by successively burning the sediments at $950^{\circ} \mathrm{C}$ for 2 hours (Heiri et al., 2001). Alternatively, coarse sand samples from the shallow trenches were treated with $10 \% \mathrm{HCl}$. Acid leaching ensures more efficient carbonate dissolution particularly for sediments that are predominantly carbonate but do not contain significant amount of mud (Dean, 1974).

Particle size analysis was performed using composite methods of laser diffraction for fine-grained fractions and digital imaging for coarse-grained sediments. For fine-grained sediments, subsamples of about $\mathrm{lg}$ were treated with $15 \% \mathrm{H}_{2} \mathrm{O}_{2}$ to remove organics. The samples were then rinsed in distilled water before introducing to the Malvern Mastersizer 2000 for grainsize analysis using laser diffraction (as outlined in Switzer, 2013). In contrast, a CAMSIZER ${ }^{\circledR}$ was used for samples that are predominantly coarse grained $(>1.5 \mathrm{~mm})$, beyond the range of the laser particle machine, and with minimal mud content. The CAMSIZER ${ }^{\circledR}$ provides non-destructive and rapid grain size and shape distributions for sediments ranging from 20 microns to 30 millimeters by capturing images of a falling curtain of sediment at $25 \mathrm{~Hz}$ (Moore et al., 2006). Prior to grainsize analysis, large organic debris were picked using forceps while the smaller, fibrous organic debris were removed by floatation on distilled water. The sediments were then oven dried at $50^{\circ} \mathrm{C}$, and about $50 \mathrm{~g}$ to $100 \mathrm{~g}$ of dry subsamples were introduced on the Retsch Technology CAMSIZER $®$. The grainsize corresponds to the cross-sectional area of the particles in the image and reported as the diameter of a circle of equivalent area, which is similar to the grainsize measuring principle of the laser particle analyzer (Switzer and Pile, 2015). The composite grainsize data of 
the Haiyan sediments and the pre-Haiyan soil were then run through the opensource program GRADISTAT version 8.0 (Blott and Pye 2001) to generate statistical grainsize distributions. The logarithmic mean, $\mathrm{d}_{90}$, sorting, and skewness (Folk and Ward, 1957) of each sample were used to establish the vertical and across-shore variations of the Haiyan sediments.

\subsubsection{Application of the TsuSed model (TsuSedMod)}

The inverse model of Jaffe and Gelfenbaum (2007), TsuSedMod, has been field tested against deposits of the 1998 Papua New Guinea tsunami (Jaffe and Gelfenbaum, 2007), the Indian Ocean Tsunami of 2004 (Spiske et al., 2010), the 2009 Samoa tsunami (Jaffe et al., 2011), and the 2011 Tohoku-oki tsunami (Jaffe et al., 2012). Given the tsunami-like properties of the Haiyan surge on this coast, however, provides the opportunity to apply the model on the Haiyan sediments found on the coastal plain. The model can be applied only to the two adjacent samples in the coconut forest (Ca4) and on the rice field (Ca 11) as these samples fall within the size particle and deposit thickness requirement of the model.

The model is constrained by several simplifying assumptions including (1) onshore flow is steady and uniform, (2) transport and deposition of sediment are dominated by suspension load ( $>90 \%)$, and (3) no erosion is caused by following waves or backwash (Brill et al., 2014) and the model is only considered to provide reliable values for onshore flow speed in cases where these assumptions apply. It has also been stated that ideally the model should be used in shallow and gently sloping coastal plains that are flooded by long tsunami waves (Apotsos et al., 2012). The collective Hernani reef flat-mangrove-coastal plain studied here spans more than 
$900 \mathrm{~m}$ and rises less than $4 \mathrm{~m}$. The duration and flow characteristics from local resident accounts and video footage suggest that the flow was indeed long wave in nature.

For tsunami studies on siliciclastic coast the TsuSedMod requires the averaged grain-size distribution and deposit thickness of only those sections of the deposit, interpreted as deposited from suspension during a single inflow (Jaffe et al., 2011, Brill et al., 2014), and as the flow depth. We used the whole sediment deposit thickness because the deposits at Hernani show only minor inverse grading and though Jaffe et al., (2011) suggest normal grading (presumably from suspension) is common in tsunami deposits there are several reasons why inverse grading can equally be found in washover deposits. For example Shanmugan (2012) noted that inverse grading has been associated with deposits of both tropical cyclones (Spiske and Jaffe 2009) and tsunamis (Jaffe et al. 2003). The origin of inverse grading at Hernani is likely related to shell fragments and the biotic composition including the many foraminifera.

The flow depth was estimated between $3 \mathrm{~m}$ to as high as $5 \mathrm{~m}$ from eyewitness accounts and field evidence. Other model parameters were kept constant for all samples. Like Brill et al. (2014) we adopted resuspension coefficient, eddy viscosity, and settling velocity from Jaffe and Gelfenbaum (2007) and a Manning's $\mathrm{n}$ of 0.03 for bottom roughness was adopted from Jaffe et al. $(2011,2012)$. We applied a sediment density $\left(2.5 \mathrm{gcm}^{-3}\right)$, salinity $(33 \%)$, and water temperature of $25^{\circ} \mathrm{C}$ to adapt to the local conditions at Hernani. 


\subsection{Results and Discussion}

\subsubsection{Reef flat boulder deposition}

Carbonate boulders on the reef flat south of Hernani area most likely derived from two sources, they are either detached from the limestone cliffs or from the active reef edge. But, in some cases the boulders could also be pre-existing, deposited by previous high-energy wave conditions and were lying loosely on the reef prior to Haiyan just as what has deduced from the boulder deposition in Guiuan, more proximal to Haiyan's landfall (Kennedy et al., 2015). Four of the boulders (i.e. $\mathrm{CB} 1, \mathrm{CB} 2, \mathrm{CB} 3, \mathrm{CB} 4)$ are found near the limestone cliffs (Fig. 4.3) with attached roots and stumps in growth position indicating a former upper boulder surface that was subaerially exposed (Fig. 4.4a). The proximity to the limestone cliffs and the subaerial pre-transport position suggest that the boulders were transported to the reef flat by cliff-top collapse. Notably, these boulders are larger than all others on the platform with the $\mathrm{b}$ axis exceeding $2 \mathrm{~m}$ in all cases and calculated weights from $13 \mathrm{t}$ to as much as $84 \mathrm{t}$ (Table 4.1). In contrast, the smaller boulders which represent the majority of the clasts have an indeterminate source. However, boulders with bleached encrusting coral or macroalgae on their surfaces were most likely submerged prior to transport and may have came from the reef slope. The dark color, and absence of fresh cut marks on the landward most boulders argue for detachment from the original source and potentially lying loosely on the reef flat prior to Haiyan (Fig. 4.4b,d). On a rare instance, fresh detached surface on boulder CB5 indicates clear overturning with a vertical displacement of $\sim 1 \mathrm{~m}$ and a lateral displacement of $50 \mathrm{~cm}$ to $1 \mathrm{~m}(\mathbf{F i g}$. 4.4c). Majority of these boulders have b axis between 1 to $2 \mathrm{~m}$ and weigh no more than $10 \mathrm{t}$ (Table 4.1). 

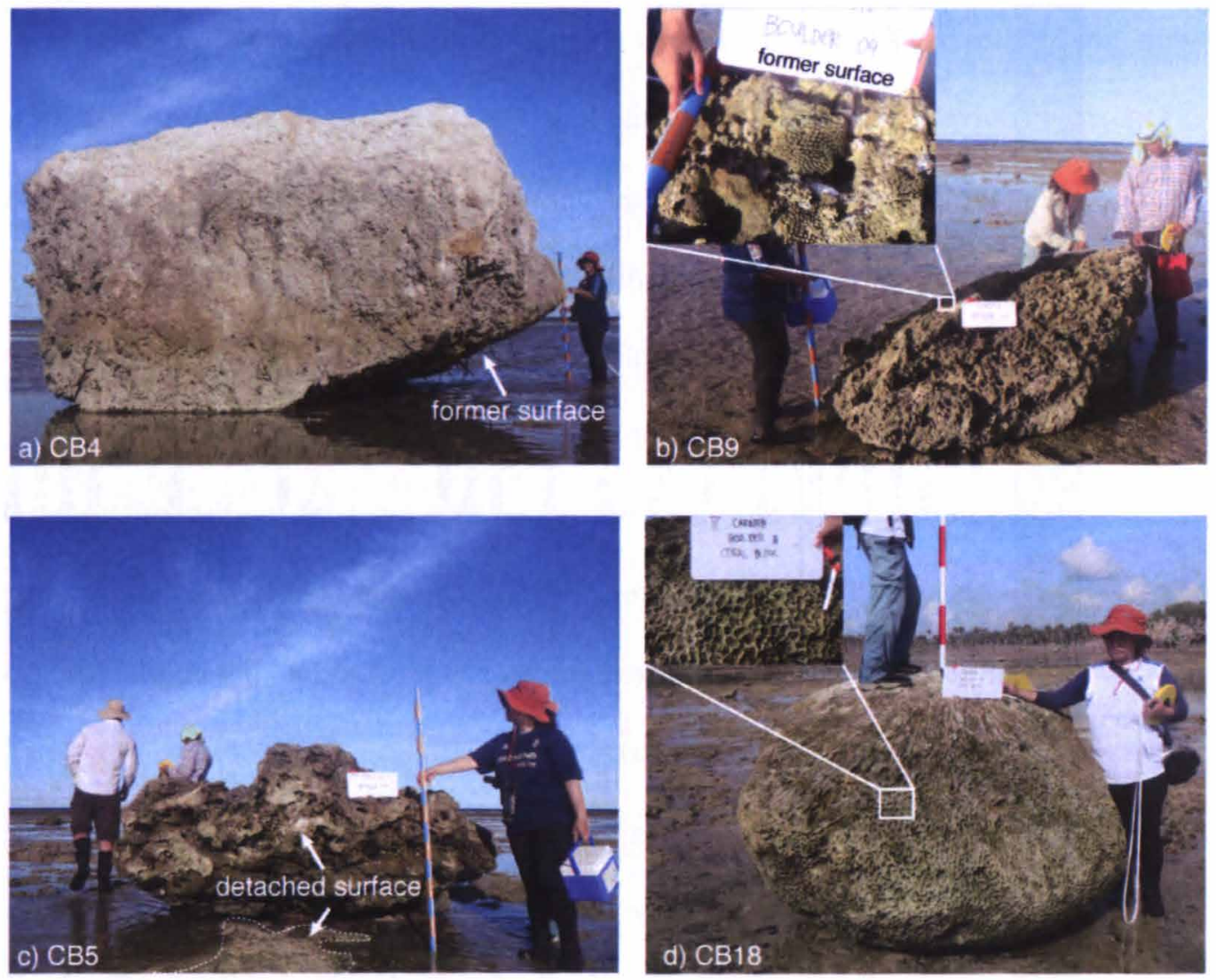

Figure 4.4. Boulders on the reef flat surface south of Hernani.

a) Boulder CB4 is about $84 \mathrm{t}$ and the largest on the reef flat. The boulder is now lying upside down on the reef flat surface.

b) Boulder CB9 showing dead but well preserved corals in growth position as evidence of former surface position.

c) Irregular shaped boulder CB5 showing a recently exposed surface an indication of overturning.

d) Boulder CB18 is a coral block in an upside down position. 


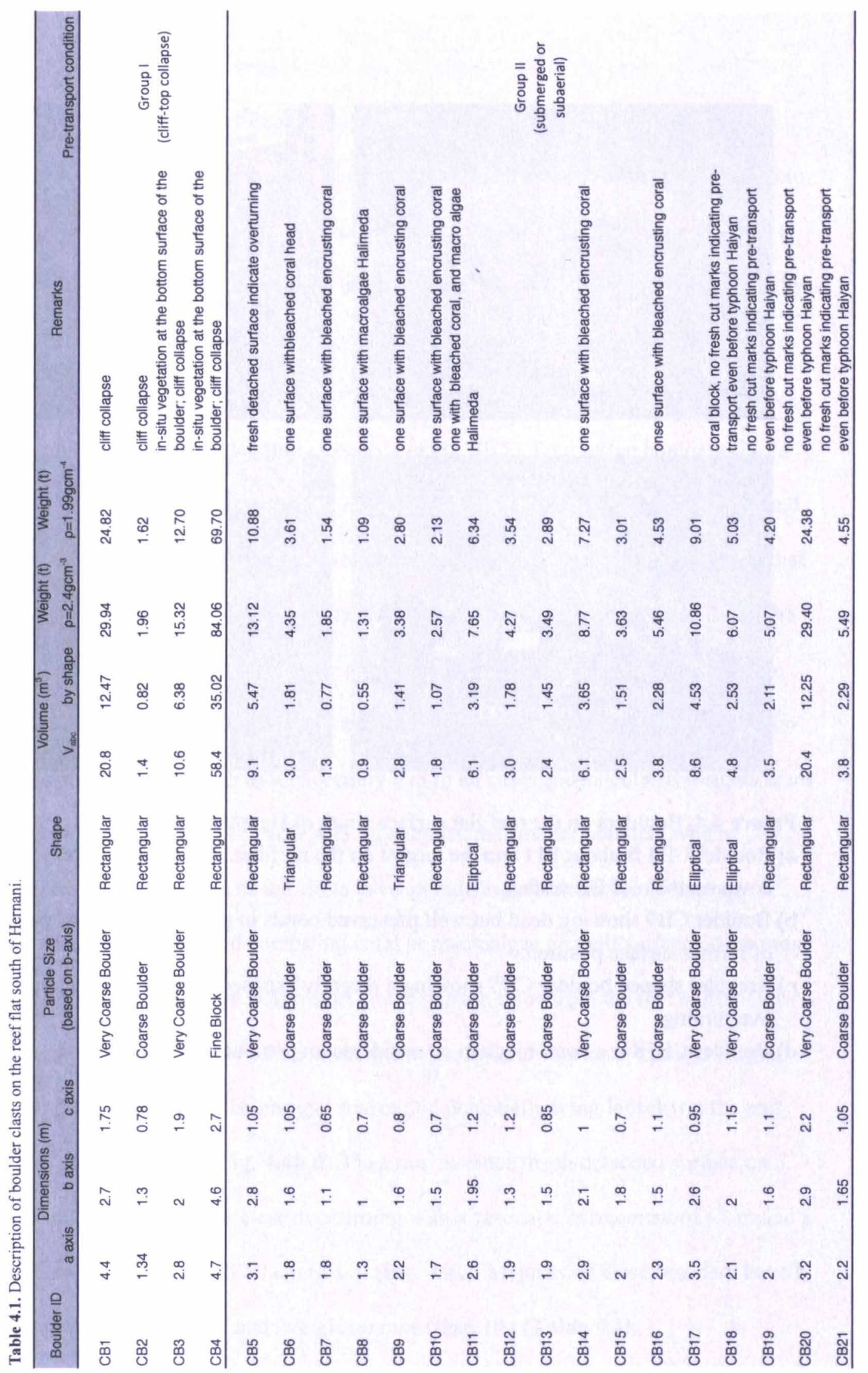


Boulder dimensions based on the equations of Nandasena and others (2011) yielded flow velocities on the reef flat ranging from $2.5 \mathrm{~ms}^{-1}$ to $12 \mathrm{~ms}^{-1}$ depending on transport mechanism (Fig. 4.5). Assuming that the boulders are previously detached from the reef prior to transport during Haiyan, a minimum flow velocity of $2.5 \mathrm{~ms}^{-1}$ to $3 \mathrm{~ms}^{-1}$ is required to initiate sliding transport. For the boulders to be moved by rolling or overturning requires minimum flow velocity of 4 to $6 \mathrm{~ms}^{-1}$. Flow velocity of at least $10 \mathrm{~ms}^{-1}$ is needed to initiate boulder transport by saltation. Based on the rarity of fresh cut boulder surfaces and impact marks, transport by rolling is the most likely transport scenario. Approximately $1.5 \mathrm{~km}$ north of our boulder field on the reef in front of Hernani township (Fig. 4.1) Roeber and Bricker (2015) summise a Boussinesq-type phase-resolving wave model BOSZ that flow velocities caused by surf beat on the reef front and immediate reef flat would be around $3 \mathrm{~ms}^{-1}$. Their modelled flow velocity of at least $3 \mathrm{~ms}^{-1}$ suggests flow capable of moving reef boulders by rolling and sliding.

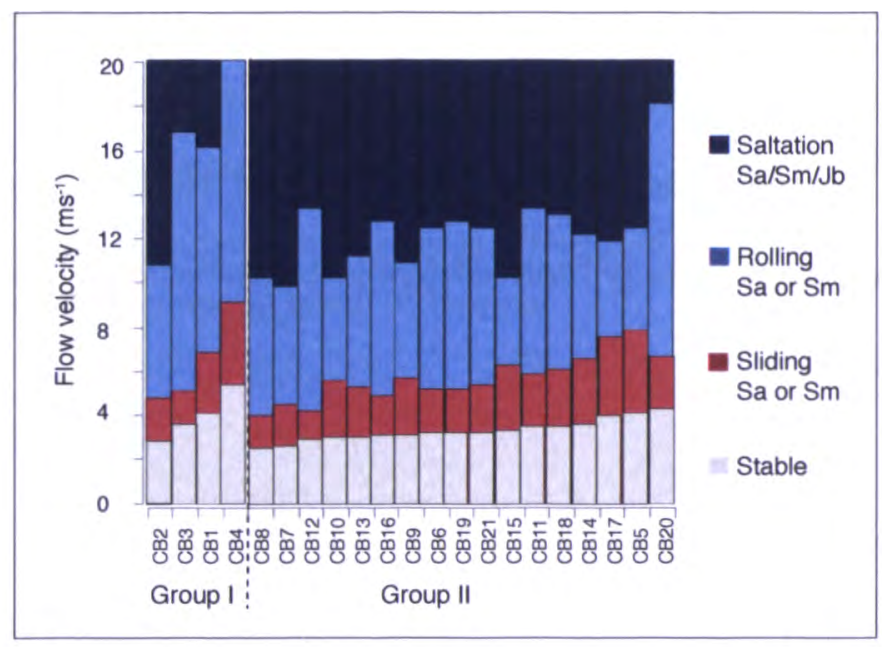

Figure 4.5. Estimated flow velocities recquired to initiate transport of a subaerial (Sa), submerged $(\mathrm{Sm})$, or joint-bounded $(\mathrm{Jb})$ boulder through three different mechanisms like sliding, rolling, and saltation using Nandasena et al. (2011) equations. 
In comparison at two different sites along Eastern Samar, May and others (2015) and Kennedy and others (2016) independently documented that Typhoon Haiyan dislocated and transported large boulders onshore to elevations between 8 to $10 \mathrm{~m}$. At both locations these authors used the size and the transport distance of the Haiyan-emplaced boulders to strongly challenge pre-existing hypothesis of attributing similar-sized boulders to tsunami events. In contrast, this study illustrates that despite the proximity and potential similarity of flooding mechanism at our study sites, we find no boulders larger than $80 \mathrm{t}$ and relatively short transport distances. Boulder deposition on the fringing reef south of Hernani was limited to the reef flat surface and no boulders onshore. Also comparing boulder dimensions, the boulders south of Hernani with $<4 \mathrm{~m}$ (a axis) and $<2 \mathrm{~m}$ (b-axis) are smaller compared to the boulders investigated by May and others (2015) on a site $5 \mathrm{~km}$ north of Hernani. Such local variability in size and spatial distribution may imply that size and transport distance do not necessarily translate directly to flooding intensity. Majority of the large boulders in Guiuan were derived from the heavily weathered headland limestone (Kennedy et al., 2016). The same applies at the north Hernani site of May et al., (2015). In contrast, we found that only four of the boulders found south of Hernani came from cliff collapse with the large majority from indeterminate pre-transport locations though likely to be the reef front.

\subsubsection{Onshore sediment deposition}

The inundation limit of the Haiyan storm surge in Carmen reached as far as $400 \mathrm{~m}$ inland of the beach, however, identifiable onshore sediment deposition reached only about $300 \mathrm{~m}$ at the front of the limestone ridge (Fig. 4.6). The sand sheet is 


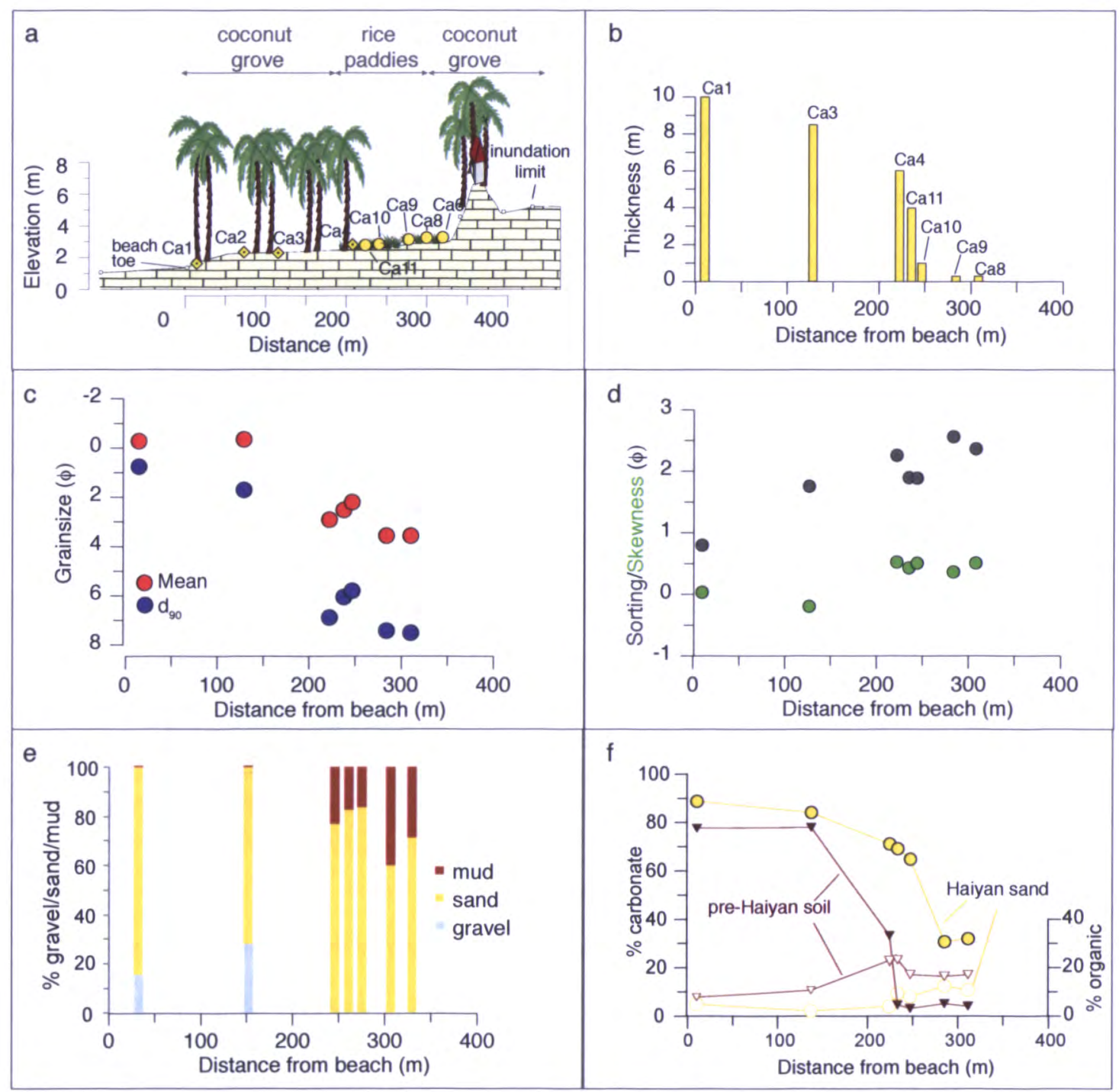

Figure 4.6. Lateral variation in thickness (b), texture (c-e), and composition (f) of the Haiyan overwash sediments south of Hernani. 
composed of carbonate sand and coral rubble that blankets the slightly inclined topographic surface at elevations of $2 \mathrm{~m}$ to $3 \mathrm{~m}$ above msl occupied by coconut groves and rice paddies. A sharp contact separates the light beige sandy unit interpreted as Haiyan deposit and the dark brown, densely rooted pre-Haiyan soil unit below (Fig. 4.7).

The most seaward trench Cal revealed the thickest accumulation of the Haiyan deposit at $10 \mathrm{~cm}$ thick. The Haiyan deposit gradually thins to about $4 \mathrm{~cm}$ through the landward edge of coconut grove. The boundary between the coconut grove and adjoining rice paddies mark an abrupt decrease in sediment thickness to $1 \mathrm{~cm}$ at Cal0 then spreading thinly to few $\mathrm{mm}$ and becoming patchy at $\mathrm{Ca} 9$ and Ca8 (Fig. 4.6b). A $3 \mathrm{~cm}$ thick Haiyan deposit was encountered in the trench $\mathrm{Ca} 2$ a few meters landward of Ca1, but was subsequently disregarded and abandoned because residents confirm that the site was disturbed by previous clearing operations.

Apart from the landward thinning trend, the Haiyan deposit also exhibits prominent textural and compositional variation landward. Figure 4.6c shows that the grainsize fines inland. The sand unit is predominantly coarse sand $(-1 \phi)$ near the beach and it remains coarse to around $150 \mathrm{~m}$ inland before it rapidly becomes fine to very fine sand ( 2 to $4 \phi$ ). Consistent with this abrupt decrease in grainsize is the shift from negatively skewed to positively skewed sediments indicating a landward shift towards a dominance of fine material (Fig. 4.6d). On the other hand, there is an apparent overall increase in sorting values inland, from moderately-sorted sediments in Cal to subsequently poorer sorted sediments 

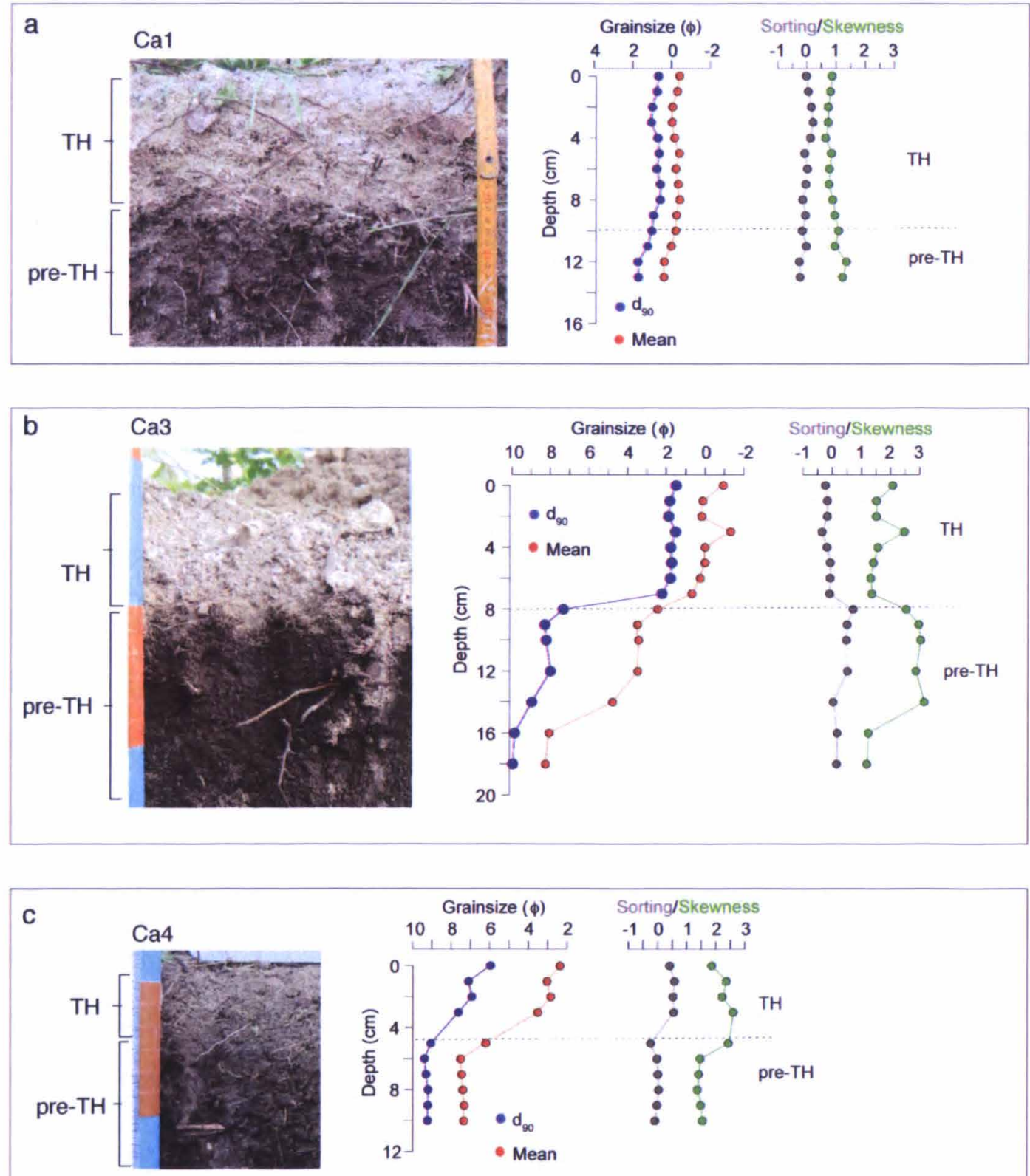

Figure 4.7. Photos of the shallow trenches showing the distinct light-colored sediments deposited by Typhoon Haiyan (TH) conformably overlying a dark-brown, pre-Haiyan (pre-TH) soil cover underneath the coconut grove. The sharp stratigraphic contact also corresponds to sharp changes in grainsize, sorting, and skewness in trenches $\mathrm{Ca} 3$ (b) and $\mathrm{Ca} 4$ (c). 
landwards to Ca8 possibly reflecting the incorporation of material from different environments as the flow moves across the land surface.

The sharp stratigraphic contact between the Haiyan deposit and the pre-Haiyan soil corresponds to evident vertical change in grainsize, sorting and skewness (Fig. 4.7). Though devoid of internal layering, the thicker and sandier parts of the Haiyan deposit exhibit an overall inverse grading or coarsening upward sequence . Inverse grading in sandy deposits has been identified and characterised in both storm (Spiske and Jaffe 2009) and tsunami deposits (Jaffe et al. 2003). In a coastal overwash settings inverse grading is likely the product of changes in flow density and characteristics analogous to dispersive pressure in grain flows (Bagnold, 1954), traction carpets in high-density turbid currents (Lowe, 1982) and kinetic sieving similar to that observed in submarine gravity flows (Middleton, 1970). The base of the Haiyan deposit is marked by either a more negatively skewed (Cal or $\mathrm{Ca} 3$ ) or a more positively skewed (Ca4) sediments compared to the underlying pre-Haiyan soil. Notably, despite the compositional differences and local flooding mechanism these onshore carbonate Haiyan sediments seem to display a similar coarsening upward sequence typically observed on the siliciclastic Haiyan sediments in Tanauan along the San Pedro Bay coast (Chapter 3).

Inverse modeling of flow speed and flow depth was conducted for Haiyan deposits to get a first order estimate flow velocity on the coastal plain. The TsuSedMod output for $\mathrm{Ca} 4$ and Cal1 is shown in Table 4.2. The onshore flow depths of $3 \mathrm{~m}$ and $5.1 \mathrm{~m}$ were used on these two adjacent samples. The derived flow velocities at $130 \mathrm{~m}$ inland is $>7 \mathrm{~m}^{\mathrm{s}-1}$ and at $220 \mathrm{~m}$ inland decreases to $4 \mathrm{~m}^{\mathrm{s}-1}$. 
Table 4.2. Across transect summary of the deposit thickness, grainsize, and flow characteristics in Carmen, south of Hernani.

\begin{tabular}{cccccccc}
$\begin{array}{l}\text { Sample } \\
\text { ID }\end{array}$ & $\begin{array}{l}\text { Distance from } \\
\text { beach }(\mathbf{m})\end{array}$ & $\begin{array}{l}\text { Thickness } \\
(\mathbf{c m})\end{array}$ & $\begin{array}{l}\text { Grainsize } \\
\mathbf{d} 90(\mathbf{p h i})\end{array}$ & $\begin{array}{l}\text { Grainsize } \\
\text { Mean }(\mathbf{p h i})\end{array}$ & $\begin{array}{l}\text { Surface } \\
\text { Elevation } \\
(\mathbf{m})\end{array}$ & $\begin{array}{l}\text { Flow } \\
\text { depth } \\
(\mathbf{m})\end{array}$ & $\begin{array}{l}\text { Flow } \\
\text { velocity } \\
\left(\mathbf{m s}^{-1}\right)\end{array}$ \\
\hline $\mathrm{Ca} 1$ & 10 & 10 & 0.76 & -0.28 & 1.70 & 5.8 & - \\
$\mathrm{Ca} 3$ & 60 & 8 & 1.70 & -0.35 & 2.30 & 5.2 & - \\
$\mathrm{Ca} 4$ & 137 & 6 & 6.89 & 2.91 & 2.40 & 5.1 & $7.16\left(7.5^{\star}\right)$ \\
$\mathrm{Ca} 11$ & 224 & 4 & 6.05 & 2.52 & 2.40 & 5.1 & $3.9\left(4^{\star}\right)$ \\
$\mathrm{Ca} 10$ & 233 & 1 & 5.80 & 2.20 & 2.40 & 5.1 & - \\
$\mathrm{Ca} 9$ & 247 & 0.3 & 7.42 & 3.56 & 2.50 & 5 & - \\
$\mathrm{Ca} 8$ & 285 & 0.3 & 7.51 & 3.57 & 3.10 & 4.4 & - \\
$\mathrm{Ca} 6$ & 340 & 0 & $\mathrm{x}$ & $\mathrm{x}$ & 4.20 & 3.3 & - \\
\hline
\end{tabular}

* Flow velocity values using flow depth of $3 \mathrm{~m}$

Storm surge inundation and onshore sedimentation has occurred in the past along this coast. Notably, Hernani town was described to have turned into a "sand desert" in the aftermath of the October 1897 typhoon (Algue, 1898). Still lacking from this study is the identification of the sediment source and thus, inferring to some extent several aspects of flow dynamics such as backwash contribution similar to what has been done on the Haiyan sediments in Leyte Gulf (Pilarczyk et al., 2016). Nonetheless, this documentation of onshore Haiyan sediments can potentially provide clues in investigating previous records of storm sedimentation on this carbonate coast.

\subsubsection{Across-shore flow velocity}

The boulder assemblages and modelling of surf beat induced flow by Roeber and Bricker (2015) both indicate that flow velocities across the reef flat were likely to have exceeded $3 \mathrm{~ms}^{-1}$ with flow depths of more than $3 \mathrm{~m}$. A relatively higher onshore flow velocity of $5 \mathrm{~ms}^{-1}$ was estimated on the house located about $200 \mathrm{~m}$ from the beach (Roeber and Bricker, 2015). The TsuSedMod results indicate 
consistently high flow velocity exceeding $4 \mathrm{~ms}^{-1}$ on the coastal plain at about 220 $\mathrm{m}$ from the beach across the narrow mangrove forest, coconut grove and rice paddies. In both cases, it seems that neither the seawall on the shore in Hernani town proper nor the narrow mangrove stand in Carmen were sufficient to slow down the flow and failed as coastal protection. Given that there is no significant topographic change, it would be interesting to know whether the coastal segment between Hernani and Carmen has been impacted by similar flow velocity or perhaps the relatively wider and dense mangrove stand was able to reduce the onshore flow.

\subsection{Conclusion}

This study investigated two distinct sediment assemblages that were transported and emplaced by the extreme flooding during Typhoon Haiyan on the open-sea coast of Hernani town. The sediment assemblages include distinct carbonate boulders now occupying the reef flat surface, and a sand sheet that blanketed the coconut groves and rice fields of the coastal plain reaching up to $\sim 300 \mathrm{~m}$ inland. We documented boulders up to $\sim 80 \mathrm{t}$, most of which were originally submerged, but were transported onto the reef flat during Haiyan's surge. Boulder transport models indicate minimum flow velocities ranging from 2 to $6 \mathrm{~ms}^{-1}$ were required to initiate boulder movement by sliding and rolling. Inland of the boulder field, we find a coarse carbonate sand draping the landscape by about $10 \mathrm{~cm}$ thick near the beach thinning to $1 \mathrm{~cm}$ to few $\mathrm{mm}$ and becoming patchy up to $300 \mathrm{~m}$ inland. Preliminary inverse modeling using TsuSedMod yielded velocity values of $>4 \mathrm{~ms}^{-}$

${ }^{1}$ for the flow that transported and deposited the onshore Haiyan deposits across the coastal plain. 
Separate inverse modeling of flow velocity from boulder dimensions on the reef flat and sediment thickness and grainsize distribution inland indicate that the borelike storm surge travelled across the wide reef flat and inundated the coast at a sustainably high flow velocity exceeding $4 \mathrm{~ms}^{-1}$. The sediment-derived flow velocity estimates are remarkably consistent with previous flow velocities reconstructed from video recordings, and forward wave modeling. Our study of two, distinct, storm-induced sediment assemblages supplement present understanding of the storm surge dynamics and provide clues for initial investigation of geologic records of storm inundation on this coast.

\section{Acknowledgements}

This work comprises Earth Observatory of Singapore contribution no. xx. This research is supported by the National Research Foundation Singapore and the Singapore Ministry of Education under the Research Centres of Excellence initiative. We thank the local government executives Edgar Buco (Mayor of Hernani), and Wilmar Candido (Vice Mayor of Hernani) who granted us access to the study area. We are grateful to Joan Reotita, George Macawili, and Renzo de Lira for their generous help in collecting field data. We thank Wenshu Yap for conducting loss-on-igition analysis and Sorvigenaleon Ildefonso for processing GPS elevation data. 
Algué, J., 1898: El baguio de Samar y Leyte, 12-13 de Octubre de 1897, Manila Observatory, 1-74.

Apotsos, A., Gelfenbaum, G., and Jaffe, B., 2012. Time-dependent onshore tsunami response. Coastal Engineering 64, 73-86.

Atwater, B.F., Fuentes, Z., Halley, R. B., Ten Brink, U. S., and Tuttle, M. P., 2014. Effects of 2010 Hurricane Earl amidst geologic evidence for greater overwash at Anegada, British Virgin Islands. Advances in Geosciences 38, 21-30.

Aurelio, M. A, Pea, R. E., 2002. Geology and mineral resources of the Philippines, Vol. 1., Department of Environment and Natural Resources Mines and Geosciences Bureau, Philippines. 277-300.

Bagnold, R.A., 1954. Experiments on a gravity-free dispersion of large solid spheres in a Newtonian fluid under shear. Proc. R. Soc. London A225, 4963.

Blott, S.J. and Pye, K., 2001. GRADISTAT: a grain size distribution and statistics package for the analysis of unconsolidated sediments. Earth Surface Processes and Landforms 26,1237-1248.

Bricker, J., Takagi, H., Mas, E., Kure, S., Adriano, B., Yi, C., and Roeber, V., 2014. Spatial variation of damage due to storm surge and waves during Typhoon Haiyan in the Philippines. Journal of the Japan Society of Civil Engineers, Series B2 70, 231-235.

Brill, D.,Pint, A., Jankaew, K., Frenzel, P., Schwarzer, K., Vött, A., Brückner, H., 2014. Sediment transport and hydrodynamic parameters of tsunami waves recorded in onshore geoarchives - A case study from Thailand. Journal of Coastal Research 30, 922-941.

Brill, D., May, S. M., Engel, M., Reyes, M., Pint, A., Opitz, S., Dierick, M., Gonzalo, L. A., Esser, S., and Brückner, H., 2016. Typhoon Haiyan's sedimentary record in coastal environments of the Philippines and its palaeotempestological implications. Nat. Hazards Earth Syst. Sci. Discuss., doi:10.5194/nhess-2016-224, In review. 
Engel, M. and May, S. M., 2012. Bonaire's boulder fields revisited: evidence for Holocene tsunami impact on the Leeward Antilles. Quaternary Science Reviews 54, 126-141.

Etienne S., and Terry J.P., 2012. Coral boulders, gravel tongues and sand sheets: features of coastal accretion and sediment nourishment by Cyclone Tomas (March 2010) on Taveuni Island, Fiji. Geomorphology 175-176, 54-65.

Folk, R.L., and W.C. Ward. 1957. Brazos River bar: a study in the significance of grain size parameters. Journal of Sedimentary Petrology 27, 3-26.

Fritz, H.M., C.D. Blount, S., Thwin, M.K. Thu, and N. Chan, 2009: Cyclone Nargis storm surge in Myanmar. Nature Geoscience, 2, 448-449.

Heiri, O., Lotter, A.F., Lemcke, G., 2001. Loss on ignition as a method for estimating organic and carbonate content in sediments: reproducibility and comparability. Journal of Paleolimnology 25, 101-110.

Jaffe, B. E. \& Gelfenbaum, G. 2007. A simple model for calculating tsunami flow speed from tsunami deposits. Sedimentary Geology 200, 347-361.

Jaffe, B., Buckley, M., Richmond, B., Strotz, L., Etienne, S., Clark, K., Watt, S., Gelfenbaum, G., and Goff, J., 2011. Flow speed estimated by inverse modeling of sandy sediment deposited by the 29 September 2009 tsunami near Satitoa, east Upolu, Samoa. Earth-Science Reviews 107(1-2), 23-37.

Jaffe, B., Goto, K., Sugawara, D., Richmond, B., Fujino, S., and Nishimura, Y., 2012. Flow speed estimated by inverse modelling of sandy tsunami deposits: results from the 11 March 2011 tsunami on the coastal plain near the Sendai Airport, Honshu, Japan. Sedimentary Geology 282, 90-109.

Jaffe, B., Gelfenbaum, G. et al. 2003. Tsunami deposits - Identification and interpretation of tsunami deposits from the June 23, 2001, Peru' tsunami. In: Proceedings of the International Conference on Coastal Sediments 2003. World Scientific Publishing Corp and East Meets West Productions, Corpus Christi, TX.

Kennedy, A. B., Mori, N., Zhang, Y., Yasuda, T., Chen, S., Tajima, Y., Pecor, W., and Toride, K., 2016. Observations and modeling of coastal boulder transport and loading during Super Typhoon Haiyan. Coastal Engineering 
Journal 58(1), 1640005 1-27.

Lagmay, A. M. F., Agaton, R. P., Bahala, M. A., Briones, J. B. L. T., Cabacaba, K. M. C., Caro, C. V. C., Dasallas, L. L., Gonzalo, L. A. L., Ladiero, C. N., Lapidez, J. P., Mungcal, M. T. F., Puno, J. V. R., Ramos, M. M. A. C., Santiago, J., Suarez, J. K., and Tablazon, J. P., 2015. Devastating storm surges of Typhoon Haiyan. International Journal of Disaster Risk Reduction 11, 1-12.

Lau, A. Y. Annie, 2015. Assessing coastal hazards with high-energy wavedeposited boulders:case studies from three tropical pacific islands. Doctoral dissertation. National University of Singapore. Singapore., pp. 47-49.

Lin, I.-I., Pun,I.-F., and Lien, C.-C., 2014. "Category-6" supertyphoon Haiyan in global warming hiatus: Contribution from subsurface ocean warming. Geophysical Research Letters 41, 8547-8553 doi:10.1002/2014GL061281.

Lowe, D. R. ,1982. Sediment gravity flows: II Depositional models with special reference to the deposits of high-density turbidity currents. Journal of Sedimentary Research 52(1). 279-297

Maeda, Y., Siringan, F., 5 Omura, A., Berdin, R., Hosono, Y., Atsumi, S., and Nakamura, T., 2004. Higher-than-present Holocene mean sea levels in Ilocos, Palawan and Samar, Philippines, Quaternary International 115$116,15-26$.

May, S.M., Engel, M., Brill, D., Cuadra, C., Lagmay, A.M.F., Santiago, J., Suarez, J.K., Reyes, M., and Brückner, H, 2015. Block and boulder transport in Eastern Samar (Philippines) during Supertyphoon Haiyan. Earth Surface Dynamics 3, 543-558.

Middleton, G.V., 1970. Experimental studies related to the problem of flysch sedimentation. Geological Association of Canada Special Paper 7, $253-$ 272.

Moore A., Goff, J., Mc Adoo, B. G., Fritz, H. M., Guzman, A., Kalligeris, N., Kalsum, K., Susanto, A., Suteja, D., and Synolakis, C. E., 2011. Sedimentary deposits from the 17 July 2006 Western Java Tsunami, Indonesia: Use of grain size analyses to assess tsunami flow depth, speed, 
and traction carpet characteristics. Pure and Applied Geophysics 168, 1951-1961.

Nandasena, N. A. K., Paris, R., and Tanaka, N., 2011. Reassessment of hydrodynamic equations: minimum flow velocity to initiate boulder transport by high energy events (storms, tsunamis). Marine Geology 281, $70-84$.

Nott, J., Chague-Goff, C., Goff, J., Sloss, C., and Riggs, N.. 2013. Anatomy of sand beach ridges: Evidence from severe Tropical Cyclone Yasi and its predecessors, northeast Queensland, Australia. Journal of Geophysysical Research: Earth Surface 118, 1710-1719, doi:10.1002/jgrf.20122.

Paciente, R.B., 2014: Response and lessons learned from Typhoon "Haiyan" (Yolanda). JMA/WMO Workshop on Effective Tropical Cyclone Warning in Southeast Asia. Tokyo, Japan Meteorological Agency. [Available online at http://severe.worldweather.wmo.int/TCFW/JMAworkshop/63.THaiyan_RPaciente.pdf]

Paris, R., Naylor, L.A., Stephenson, W.J., 2011. Boulders as a signature of storms on rock coasts. Marine Geology 283,1-11.

Pilarczyk, J.E., Horton, B.P., Soria, J.L.A., Switzer, A.D., Siringan, F., Fritz, H.M., Khan, N.S., Ildefonso, S., Doctor, A.A., Garcia, M.L., 2016.

Micropaleontology of the 2013 Typhoon Haiyan overwash sediments from the Leyte Gulf, Philippines. Sedimentary Geology 339, 104-114.

Primavera, J.H., Dela Cruz, M., Montilijao, C., Consunji, H., Dela Paz, M., Rollon, R.N., Maranan, K., Samson ,M.S., Blanco, A., 2016. Preliminary assessment of post-Haiyan mangrove damage and short-term recovery in Eastern Samar, central Philippines. Marine Pollution Bulletin 109(2),744750 .

Reyes, M., Engel, M., May, S.M., Brill, D., and Brückner, H., 2015. Life and death after Super Typhoon Haiyan, Coral Reefs 34, 419.

Roeber, V. and Bricker, J., 2015. Destructive tsunami-like wave generated by surf beat over a coral reef during Typhoon Haiyan. Nature Communications 6 , 
7854. doi:10.1038/ncomms8854,

Scheffers, A., and Scheffers, S., 2006. Documentation of the imoact of Hurricane Ivan on the coastline of Bonaire (Netherlands Antilles). Journal of Coastal Research 22(6), 1437-1450.

Shanmugam, G., 2012. Process-sedimentological challenges in distinguishing paleo-tsunami deposits. Natural Hazards 63(1), 5-30.

Siringan, F.P., Gallentes, A., and Manglicmot, M. 2016. Coral inferred contemporary tsunami history of the Verde Island Passage. Unpublished Technical Report submitted to the Philippine Council for Agriculture, Aquatic and Natural Resources Research and Development. Laguna, Philippines.

Soria, J.L., Switzer, A., Villanoy, C., Fritz, H., Bilgera, P.H., Cabrera, O., Siringan, F., Sta. Maria, Y., Ramos, R., and Fernandez, I, 2016: Repeat storm surge disasters of Typhoon Haiyan and its 1897 predecessor in the Philippines. Bulletin of the American Meteorological Society 97, 31- 48

Spiske, M. and Jaffe, B. E., 2009. Sedimentology and hydrodynamic implications of a coarse-grained hurricane sequence in a carbonate reef setting. Geology 37, 839-842, doi:10.1130/G30173A.1.

Spiske, M.,Spiske, M.,Weiss, R., Bahlburg, H., Roskosch, J., and Amijaya, H., 2010. The TsuSedMod inversion model applied to the deposits of the 2004 Sumatra and 2006 Java tsunami and implications for estimating flow parameters of paleo-tsunami. Sedimentary Geology 224(1-4), 29-37.

Spiske, M. and Halley, R. B., 2014. A coral-rubble ridge as evidence for hurricane overwash, Anegada (British Virgin Islands). Advances in Geosciences 38, 9-20.

Switzer, A.D., and J. Pile, 2015. Grain size analysis. In: Shennan, I. et al. (Eds.) Handbook of Sea-Level Research. John Wiley \& Sons, Ltd., pp. 331-346.

Takagi, H., and Esteban, M., 2016. Statistics of tropical cyclone landfalls in the Philippines:unusual characteristics of 2013 Typhoon Haiyan. Natural Hazards 80, 211-222.

Tajima, Y., Yasuda, T., Pacheco, B.M., Cruz, E.C., Kawasaki, K., Nobuoka, H., 
Miyamoto, M., Asano, Y., Arikawa, T., Ortigas, N.M., Aquino, R., Mata, W., Valdez, J., and Briones, F., 2014: Initial report of JSCE-PICE joint survey on the storm surge disaster caused by Typhoon Haiyan. Coastal Engineering Journal 56, 1450006, doi:10.1142/S0578563414500065.

Terry, J.P., Lau, Annie A. Y., Etienne, S., 2013. Uncertainties and continuing challenges with interpreting coastal boulders. In: Reef-platform coral boulders evidence for high-energy marine inundation events on tropical coastlines. Springer Singapore. pp.70-72. 


\section{Chapter 5}

\section{Geomorphological and sedimentological records of recent storm history of the volcaniclastic coast in Lagonoy Gulf, central eastern Philippines}

Janneli Lea A. Soria ${ }^{1,2}$, Jeremy Pile ${ }^{3}$, Adam D. Switzer ${ }^{1,2}$, Fernando P. Siringan ${ }^{4}$, Dominik Brill $^{5}$, Arturo Daag ${ }^{6}$

\footnotetext{
'Asian School of the Environment, Nanyang Technological University, Singapore 639798

${ }^{2}$ Earth Observatory of Singapore, Nanyang Technological University, Singapore 639798

${ }^{3}$ Faculty of Science and Technology, Bournemouth University, Fern Barrow, Poole, Dorset, BH12 5BB, United Kingdom

${ }^{4}$ Marine Science Institute, University of the Philippines, Diliman, Quezon City, Philippines 1101

${ }^{5}$ Institute of Geography, University of Cologne, Albertus-Magnus-Platz D-50923

Köln/Cologne

${ }^{6}$ Philippine Institute of Volcanology and Seismology (PHIVOLCS), PHIVOLCS

Building, C.P. Garcia Avenue, UP Campus Diliman, 1101 Quezon City, Phillipines
}

Partly Published in: GPR2016 IEEE Conference Proceeding

For submission to Geomorphology

Keywords: Typhoon Durian, overwash, washover fan, washover terrace, volcaniclastic coastal barrier systems, Ground Penetrating Radar (GPR) 


\section{Contributions}

Lea is the primary author, and with Adam, and Fernando conceptualized the idea, identified appropriate methods, and contributed to its formality and development. Lea conducted the sedimentological analyses, supervised student interns conducting grainsize analysis, interpreted and synthesized sediment and GPR data, and wrote the paper. Jeremy collected, analyzed and contributed GPR data used in this study.

Dominik conducted OSL-dating and interpreted OSL results. The Philippine Institute of Volcanology and Seismology through Art provided the GPR equipment and discussed geological insights of the volcanoes found in the study area.

Janneli Lea A. Soria: $60 \%$

Jeremy Pile: $15 \%$

Adam D. Switzer: $10 \%$

Fernando P. Siringan: $7 \%$

Dominik Brill: $5 \%$

Arturo Daag: $3 \%$ 


\section{Abstract}

The Philippine islands lie in the path of tropical cyclones, and many of the coastlines are prone to marine inundations due to storm surges. One recent event was Typhoon Durian, which made landfall in Bicol on 30 November 2006 and generated a storm surge. However, we lack understanding of the storm surge inundation process because instrumental records and immediate post-typhoon surveys were limited. Satellite imagery from 2007 reveal evidences that Typhoon Durian significantly eroded and breached a barrier sand spit north of Tabaco City. Typhoon Durian has left significant geomorphic and sedimentological imprints in the volcaniclastic landscape including overwash fans and terraces. We used the surface elevation of the overwash fans, terraces and relict dunes to estimate inundation heights. In the same way, the Typhoon Durian's geomorphic and sedimentological imprints serve as modern reference to investigate similar inundation events in the geologic past using ground penetrating radar (GPR) imaging. The remnants of the pre-storm dune profile have elevations ranging from 3.5 to $4 \mathrm{~m}$, which imply that breaching likely resulted from inundation considerably higher than $1.5 \mathrm{~m}$ but not exceeding $3 \mathrm{~m}$. The typhoon washover deposit resembles the typical washover fan stratigraphy, and exhibits horizontal to sub-horizontal lamination on the front to mid-fan and foreset stratification at the fan terminus. The Durian washover deposit has a sharp, erosional base marked by abrupt coarsening of the sediments. The internal stratigraphy was investigated using Ground Penetrating Radar (GPR), and shore-normal transects reveal at least two and possibly 3 buried erosional surfaces farther inland of the erosional surface of Typhoon Durian. Similar to Durian, the older erosional surfaces were probably sustained from previous typhoons. 


\subsection{Introduction}

Typhoon Durian in December 2006 generated a storm surge that caused landscape changes and left storm deposits on a volcaniclastic barrier spit along Lagonoy Gulf in central eastern Philippines (Fig. 5.1). Though this storm surge was a fraction of the size of that of 2013 Typhoon Haiyan (Soria et al., 2016), it has breached segments of the dune. We have limited knowledge on the local hydrodynamic conditions of Typhoon Durian's storm surge. The tide gauge installed by the National Mapping and Resources Agency (NAMRIA) has failed and there was no wave gauge information. The only available information is that of Loy and others (2010), who estimated the storm surge reaching about $1 \mathrm{~m}$ in Lagonoy Gulf. However, their study suffered from a number of limitations. Their 2D shallow-water model, only used pressure and wind field forcing, which is typically only applicable to the offshore region. Consequently, their model fails to account for contributions of high-water level from wave set-up and wave run-up onshore, and would almost certainly only provide a conservative estimate of storm surge height (Nott, 2006).

To account for the wave set-up and the wave run-up components including the likely extent of erosion caused by Typhoon Durian we will follow the marine inundation concept of Nott and Hubbert (2005). They showed that inundation magnitude of cyclones Vance and Chris in Australia could be reconstructed from geomorphological indicators provided that post-storm modifications are carefully considered. On the Malinao spit, erosional and depositional landforms such as washover fans and terraces from Typhoon Durian remain evident. Similar erosional and depositional features induced by storms were documented elsewhere particularly along barrier islands on the US Atlantic and Gulf coasts (e.g. Leatherman, 1981; Sedgwick and 
Davis, 2003; Williams, 2015). We will adopt the terms for the breached-related erosional and depositional features as defined by Leathermann (1981), Morton (2002) and Morton and Sallenger (2003).

a)

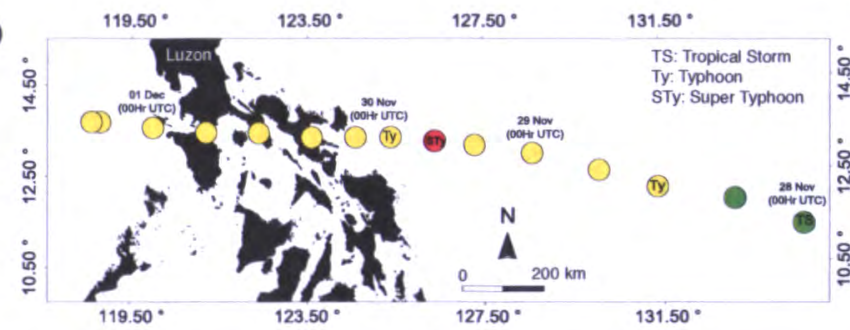

b)

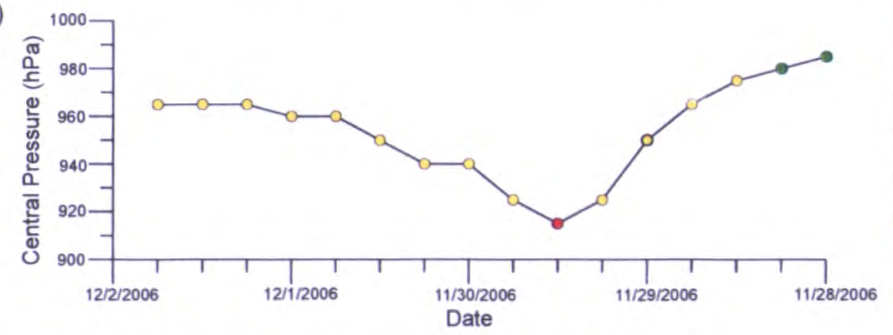

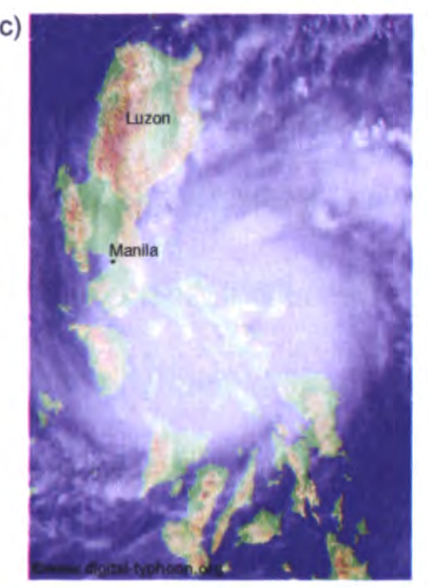

Figure 5.1. Typhoon Durian crossing central Philippines.

a) Snapshot of the track of Typhoon Durian from 28 November to 01 December 2006.

b) Along track changes in central pressure.

c) Satellite image (MTSAT-1R) of typhoon Durian upon landfall on the western coast of Lagonoy Gulf as processed by National Institute of Informatics in Japan.

In addition to characterizing the landform features of Durian overwash we also investigate whether storm-induced erosion and deposition of the past events are preserved in the barrier sand spit stratigraphy. The storm erosion and recovery cycle in coastal environments is well known (e.g. Yu et al., 2013; Switzer, 2015) and where defined by 'cut and fill' in the subsurface it can commonly be revealed from ground penetrating radar (GPR) imaging (e.g Buynevich et al., 2004, 2007; Lindhorst et al., 2008; Cunningham et al., 2011). Apart from being a hazard to coastal communities, storm-induced erosion and deposition has been also recognized as an important mechanism for sediment redistribution along the coast, and as such, a vital 
component in the evolution of barrier islands and beach ridges (e.g. Moller and Anthony, 2003; Buynevich et al., 2004; Wang and Horwitz, 2007; Nott et al., 2013).

\subsection{Study Area}

\subsubsection{Typhoon Durian in the Philippines}

Between 30 November 2006 and 1 December 2006, Typhoon Durian packed with strong wind accompanied with heavy rainfall crossed over central Philippines. A snapshot of typhoon Durian's track is shown in Figure 5.1a. On $28^{\text {th }}$ November, tropical storm Durian entered the Philippine Area of Responsibility and the Philippine Atmospheric, Geophysical and Astronomical Services (PAGASA) assigned it a local name Reming. The international name Durian, however, will be used in this paper. On the same day, Durian intensified to a typhoon category. On $29^{\text {th }}$ November, Durian had reached maximum sustained wind speeds of about $250 \mathrm{kph}$ and a central pressure of $915 \mathrm{hPa}$ (Fig. 5.1b); and the Joint Typhoon Warning Center (JTWC) classified it as a Super Typhoon. On $30^{\text {th }}$ November, Durian weakened again into a typhoon as it came ashore along the southern coast of Catanduanes Island. At landfall, a synoptic station of PAGASA in Catanduanes recorded a minimum sealevel pressure of $934 \mathrm{hPa}$, and peak gusts reaching as high as $320 \mathrm{kph}$. Durian continued its westerly track and made a second landfall along the western coast of Lagonoy Gulf (Fig. 5.1c).

\subsubsection{Notable historical storms in Lagonoy Gulf and surrounds}

Figure 5.2 shows the tracks of the storms that have impacted Lagonoy Gulf and nearby coastlines. These storms, according to the data compiled by Alojado (2015), were notable either because of their typhoon intensity (e.g. Durian, Joan), high cost of 
damage (Angela), or human death toll exceeding 500 (e.g. Durian, Angela, Nina, Joan). Similarly, based on unpublished PAGASA dataset and map of historical storm surge occurrences in the Philippines covering the period 1897 to 2011, we highlight the typhoons that have generated storm surges in Lagonoy Gulf (Table 5.1). Typhoon Durian was just one among the five known storm surge events that have occurred in the recent past (Fig. 5.2). Local residents also recounted an event when Typhoon Joan (Sening) on October 1970 generated a storm surge that washed away the houses in a small village called Natunawan (which literally means dissolved) at the terminus of the barrier sand spit (Fig. 5.3b). So far, the most notable event was the 2 to $\sim 7 \mathrm{~m}$ storm surges generated by the 1897 Typhoon Nina (PAGASA, 2000 and PAGASA, 2011).

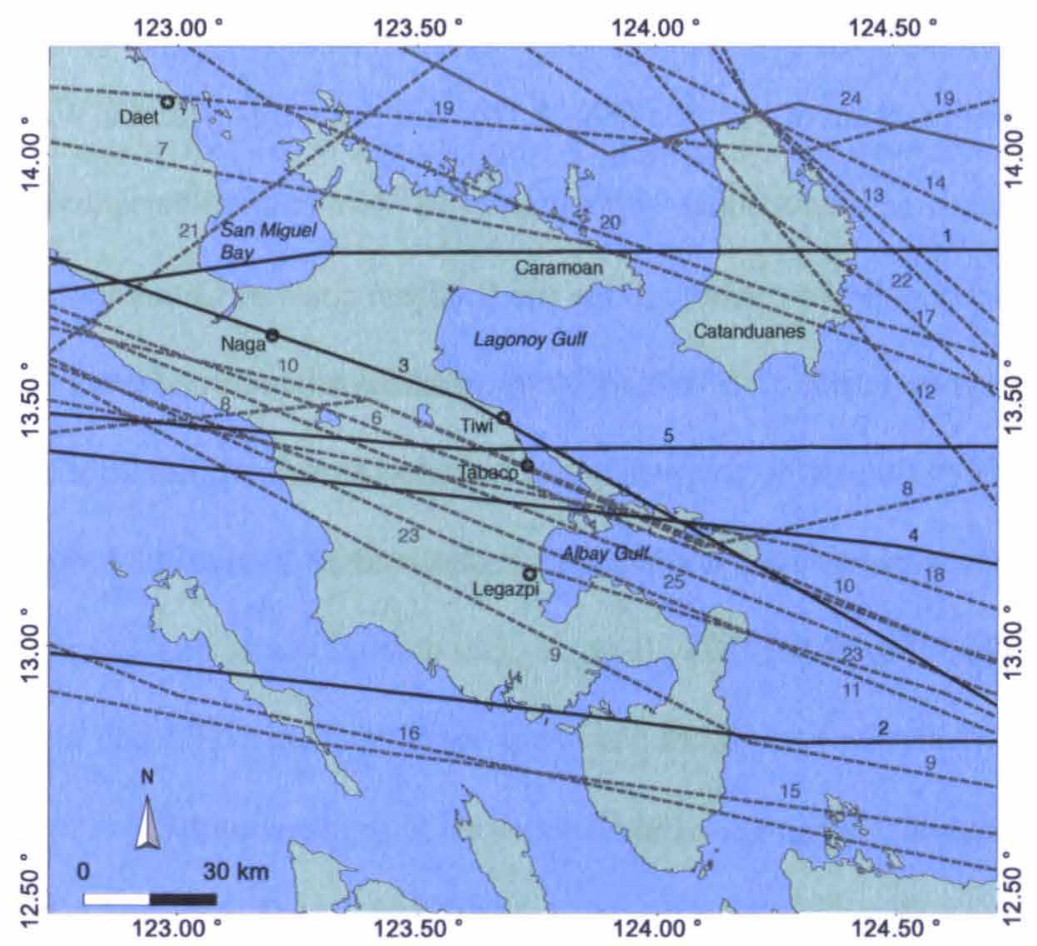

Figure 5.2. Landfalling tropical cyclones in the surrounding area of Lagonoy Gulf between 1897 and 2013. Storm tracks were from the IBTrACS database of Knapp and others (2010). The attributes of each typhoon are summarized in Tables 5.1 and 5.2. 
Table 5.1. Tropical cyclones with known storm surge occurrence (PAGASA 2000) (Represented in black solid lines in Fig. 5.2).

\begin{tabular}{|c|c|c|c|c|c|c|}
\hline No. & $\begin{array}{l}\text { International } \\
\text { name }\end{array}$ & $\begin{array}{l}\text { Local } \\
\text { name }\end{array}$ & Landfall date & $\begin{array}{l}\text { Max winds } \\
\text { at landfall }\end{array}$ & $\begin{array}{l}\text { Affected } \\
\text { area }\end{array}$ & $\begin{array}{l}\text { Storm surge } \\
\text { height (m) }\end{array}$ \\
\hline 1 & Harriet & & $\begin{array}{l}30 \text { December } \\
1959\end{array}$ & $225 \mathrm{kph}$ & & undetermined \\
\hline 2 & Kit & & $\begin{array}{l}6 \text { October } \\
1960\end{array}$ & & & undetermined \\
\hline 3 & Vera & Bebeng & 14 July 1983 & $130 \mathrm{kph}$ & Legazpi & $0.65 \mathrm{~m}$ \\
\hline 4 & Nina & Sisang & $\begin{array}{l}25 \text { November } \\
1987\end{array}$ & $240 \mathrm{kph}$ & $\begin{array}{l}\text { Tiwi } \\
\text { Tabaco } \\
\text { Legazpi }\end{array}$ & $\begin{array}{l}6.88 \mathrm{~m} \\
2.6 \mathrm{~m} \\
3.9 \mathrm{~m}\end{array}$ \\
\hline 5 & Durian & Reming & $\begin{array}{l}30 \text { November } \\
2006\end{array}$ & $320 \mathrm{kph}$ & $\begin{array}{l}\text { Lagonoy } \\
\text { Gulf } \\
\text { San Miguel } \\
\text { Bay }\end{array}$ & $\begin{array}{l}1 \mathrm{~m} \\
6.6 \mathrm{~m}\end{array}$ \\
\hline
\end{tabular}

Table 5.2. Tropical cyclones with unknown storm surge occurrence (Represented in gray dashed lines in Fig. 5.2).

\begin{tabular}{|c|c|c|c|c|}
\hline No. & $\begin{array}{l}\text { International } \\
\text { name }\end{array}$ & Local name & Landfall date & $\begin{array}{l}\text { Max winds } \\
\text { at landfall }\end{array}$ \\
\hline 6 & Jean & & 25 December 1947 & $150 \mathrm{kph}$ \\
\hline 7 & Fran & & 29 December 1950 & $150 \mathrm{kph}$ \\
\hline 8 & Trix & & 21 October 1952 & $215 \mathrm{kph}$ \\
\hline 9 & Emma & Welming & 3 November 1967 & $205 \mathrm{kph}$ \\
\hline 10 & Joan & Sening & 13 October 1970 & $275 \mathrm{kph}$ \\
\hline 11 & Ora & Konsing & 24 June 1972 & $130 \mathrm{kph}$ \\
\hline 12 & Ruby & Huaning & 24 June 1976 & $185 \mathrm{kph}$ \\
\hline 13 & Vera & Yayang & 5 November 1979 & $240 \mathrm{kph}$ \\
\hline 14 & Irma & Anding & 24 November 1981 & $260 \mathrm{kph}$ \\
\hline 15 & Lee & Dinang & 25 December 1981 & $175 \mathrm{kph}$ \\
\hline 16 & Betty & Herming & 12 August 1987 & $240 \mathrm{kph}$ \\
\hline 17 & Ruby & Unsang & 24 October 1988 & $215 \mathrm{kph}$ \\
\hline 18 & Dan & Saling & 10 October 1989 & $120 \mathrm{kph}$ \\
\hline 19 & Angela & Rosing & 2 November 1995 & $255 \mathrm{kph}$ \\
\hline 20 & Babs & Loleng & 21 October 1998 & $290 \mathrm{kph}$ \\
\hline 21 & Muifa & Unding & 19 November 2004 & $130 \mathrm{kph}$ \\
\hline 22 & Nida & Dindo & 17 May 2004 & $185 \mathrm{kph}$ \\
\hline 23 & Xangsane & Milenyo & 27 September 2006 & $180 \mathrm{kph}$ \\
\hline 24 & Nock-ten & Juaning & 27 July 2011 & $95 \mathrm{kph}$ \\
\hline 25 & Rammasun & Glenda & 15 July 2014 & $130 \mathrm{kph}$ \\
\hline
\end{tabular}




\subsubsection{Coastal geomorphology}

Lagonoy Gulf is a narrow, elongate embayment openly interacting with the Philippine Sea on the central eastern Philippines (Fig. 5.3). Compared to the other neighboring embayments like San Miguel Bay and Albay Gulf, Lagonoy Gulf is uniquely deep, characterized by a steep continental shelf with maximum water depths of $1,300 \mathrm{~m}$. This study focuses on an elongate barrier sand spit referred to herein as the Malinao spit along the southeastern coast of Lagonoy Gulf. It is located on the narrow coastal plain downstream of three active stratovolcanoes Malinao, Masaraga, and Mayon, which are predominantly basaltic to andesitic (Divis, 1980; KnittelWeber \& Knittel, 1999; Castillo \& Newhall, 2004; Ozawa et al., 2004; Andal et al., 2005). Sandy to gravelly volcaniclastic sediments directly sourced from Malinao, Masaraga, and Mayon volcanoes are transported downstream through the Quinale River towards the coast. A net southeastward longshore transport redistributes the sediments on the southern bank of the Quinale River to form the spit. On the average, the Malinao spit is about $150 \mathrm{~m}$ wide and extends $7 \mathrm{~km}$ long to the southeast towards Tabaco City.

\subsection{Materials and Methods}

\subsubsection{Image interpretation and initial field investigation}

We compared satellite images taken before and after the storm to map the landscape changes caused by Typhoon Durian (Fig. 5.4). The pre-storm image was acquired on 22 March 2006, while the post-storm images were acquired on 04 May 2007 and 29 September 2011. The images were accessed through Google Earth Pro server and compiled on a Global Information System (GIS) platform using Manifold ${ }^{\circledR}$ Systems for georeferencing. 

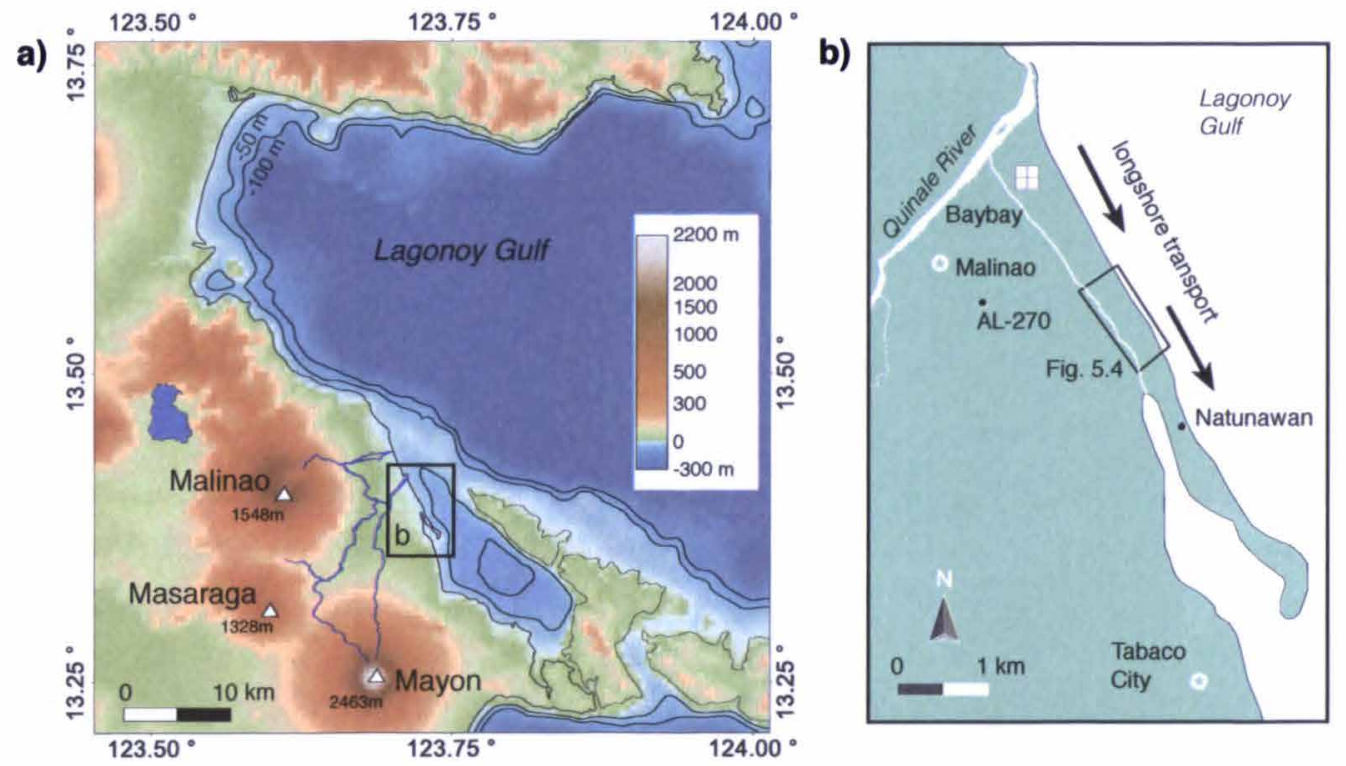

Figure 5.3. Geomorphology of the coast surrounding Lagonoy Gulf (a). The study area is located on a sandy barrier spit, on a segment of the coast that is relatively sheltered from open-sea waves.

The initial survey was conducted on June 2012 to validate the geomorphological features identified on the satellite images. Residents of the coastal village Baybay recounted that strong waves during the passage of Typhoon Durian as it breached a portion of the Malinao spit (Fig.5.5a). One prominent breaching site is about $250 \mathrm{~m}$ wide, and indicated by a disrupted line of Casuarina trees, along with a relatively lower and flatter surface bounded by erosional scarps on its northern and southern margins. The Casuarina trees, according to local officials, were planted as part of a coastal protection project in the early 1990s.

The washover fans on the two breaching sites and their associated deposits were studied in detail. Six shallow trenches, TP1 to TP6 were excavated along a transect perpendicular to the coast. The trenches were typically about $1 \mathrm{~m}$ wide and 40 to 90 $\mathrm{cm}$ deep, but varied in lengths from 1 to $7 \mathrm{~m}$. A leveling survey was conducted to 


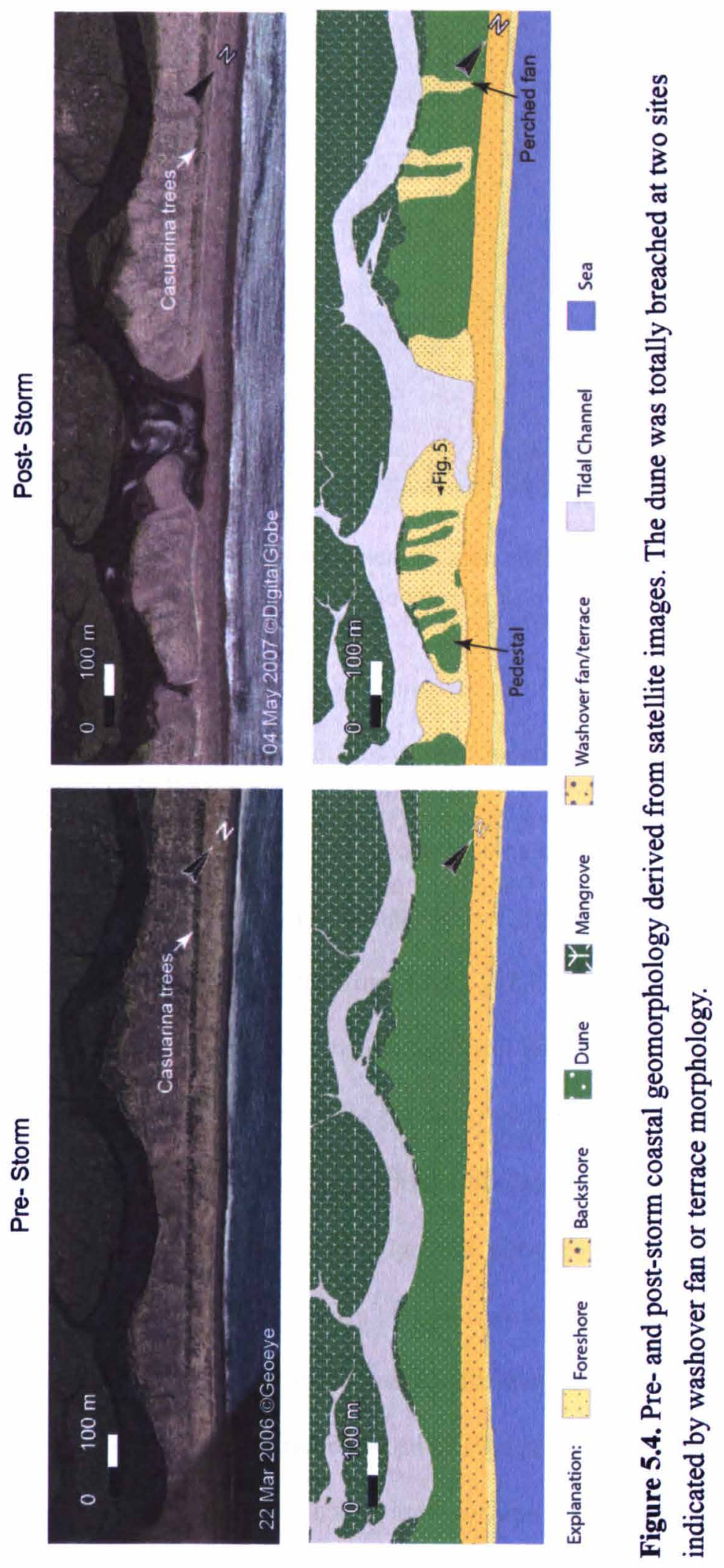



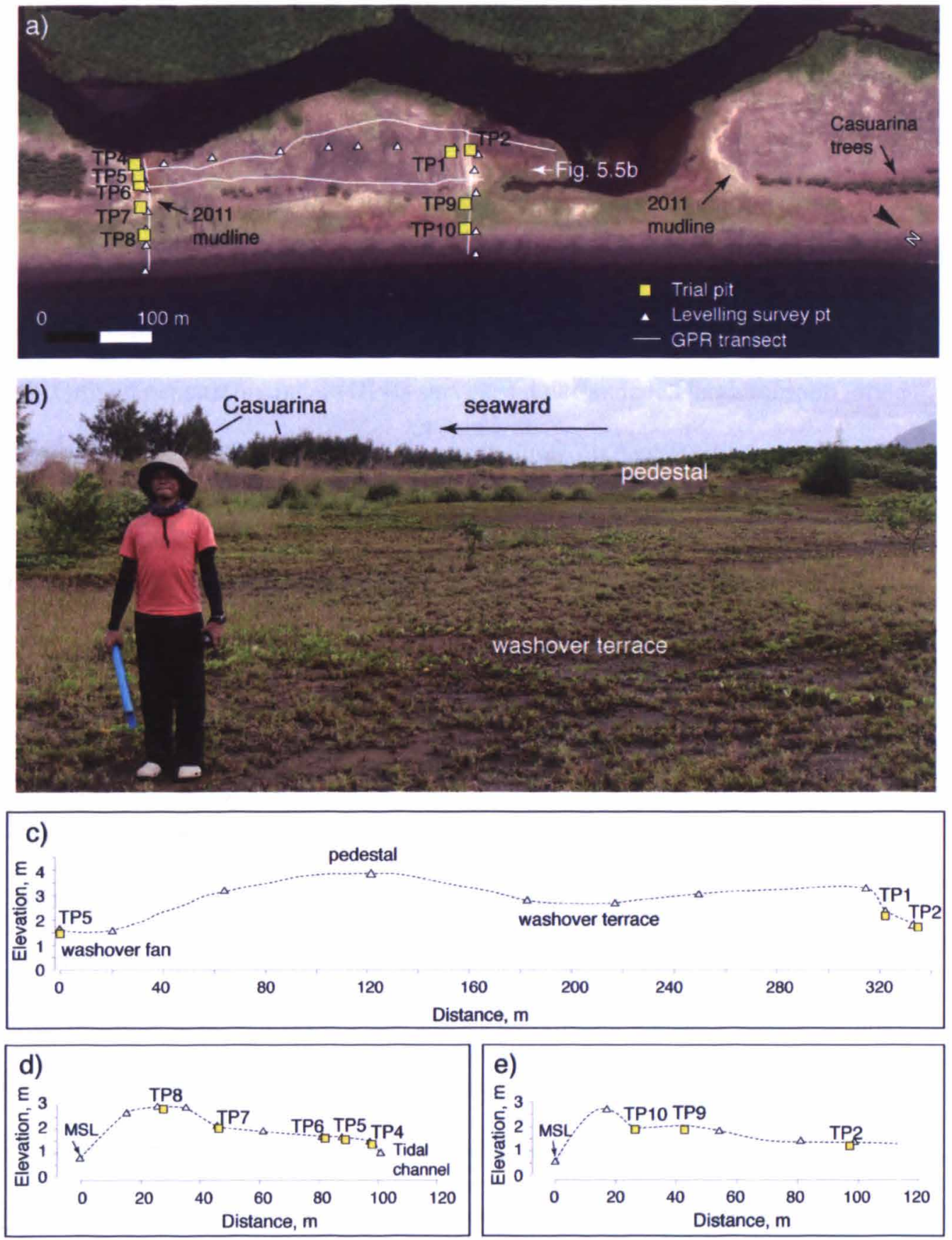

Figure 5.5. Two most prominent washover fans (terrace) on the barrier spit.

a) Google Earth image taken on 29 September 2011 showing the location of the

GPR transects and trenches (TP) .

b) The northern washover terrace bounded by an erosional scarp of the dune.

c) Along-shore profile showing that post-storm dune elevations are laterally variable. Elevations of the pedestals and washover fans suggest that the inundation level during Typhoon Durian was at least $1.5 \mathrm{~m}$ but not exceeding $3 \mathrm{~m}$.

d) Elevation profile across the southern washover fan.

e) Elevation profile across the northern washover terrace. 
determine the elevations of the trenches and the surfaces of washover features above local sea level. Using the actual tide data at Legazpi station for the duration of the survey, the raw elevations were then referenced to regional mean sea level $(\mathrm{msl})$. Sediment sequences were logged and photographed. Sediment samples were successively collected in $2-\mathrm{cm}$ intervals, and on the sedimentary contacts identified in the trenches. Grab samples of surface sediments were obtained from the beach face, berm, dune, and tidal channel.

Grainsize analysis was performed only on the lithic component of the sediments. Large organic debris and carbonate grains were picked using forceps, whereas, the smaller, fibrous organic debris were removed by floatation. The sediments were successively oven dried at $50^{\circ} \mathrm{C}$, and about $50 \mathrm{~g}$ to $100 \mathrm{~g}$ of dry subsamples were introduced on the Retsch Technology CAMSIZER $®$ for grainsize analyses. The CAMSIZER ${ }^{\circledR}$ provides non-destructive and rapid grain size and shape distributions for sediments ranging from 20 microns to 30 millimeters by capturing images of a falling curtain of sediment at $25 \mathrm{~Hz}$ (Moore et al., 2006). For the mud deposits capping several trenches, about $\mathrm{lg}$ to $2 \mathrm{~g}$ was taken in each sample for grainsize analysis. Samples were treated with $20 \% \mathrm{H}_{2} \mathrm{O}_{2}$ to remove organics and $15 \%$ hydrochloric acid $(\mathrm{HCl})$ to remove carbonate fragments. The samples were rinsed in distilled water before introducing to the Malvern Mastersizer 2000 for grainsize analyses using laser diffraction following procedures outlined by Switzer (2013).

The grainsize corresponds to the cross-sectional area of the particles in the image from the CAMSIZER and on the laser particle analyzer. The grainsize data were then run through the open-source program GRADISTAT version 8.0 (Blott 2001) 
to generate statistical grainsize distributions. The fraction of sediment by different category size (e.g. clay, very coarse silt, medium sand) along with the logarithmic (Folk and Ward, 1957) mean, median, sorting, and skewness were used to establish vertical and across-shore variations of the sedimentology of the washover fan deposits.

\subsubsection{Ground penetrating radar (GPR) survey and chronological control}

Subsequent field investigations in 2013 were focused on the breached portions of the dune and unbreached areas where erosional surfaces were likely to be preserved. A GPR survey was carried out on 13 to 16 June 2013 to image possibly buried erosion surfaces on the barrier spit (Fig. 5.5). On each of the breaching sites, a shore-normal GPR transect scanned across the barrier spit from the highwater mark of the beachface landward to the edge of the tidal channel. Shore parallel surveys were also conducted along the top of the barrier and along the landward margin of the barrier. GPR profiles were collected using a $100 \mathrm{MHz}$ Sensors and Software Noggin system on Smart Cart with antennae separation fixed at $0.5 \mathrm{~m}$. Acquisition was controlled by odometer wheel with a step size $0.1 \mathrm{~m}$ and a time window $400 \mathrm{~ns}$. Depth of penetration varied from $2 \mathrm{~m}$ to $8 \mathrm{~m}$ and we used hyperbolae matching to determine near surface velocities in order to estimate depth. Velocities of $0.07 \mathrm{~m} / \mathrm{ns}$ were used as these lie between published values of $0.06 \mathrm{~ms}-1$ for wet coastal dune sand (Switzer et al., 2006) and $0.09 \mathrm{~ms}^{-1}$ for wet though finer, volcaniclastic sand in lahars and fans (Ettinger et al., 2014). Topographic and positional data along the GPR transects were simultaneously collected using a South Survey S82-T GNSS differential global positioning system. All the points were referenced to the benchmark AL-270, a National Mapping Resources Information Agency established levelling datum located 
$\sim 1.6 \mathrm{~km}$ west of the study area. Post-survey processing and plotting utilised both EKKO_View and ReflexW software programs. Simple processing including Dewow filtering, automatic gain control, horizontal and vertical averaging were applied to the data. The radar reflection profiles for each transect were examined and interpreted using a radar facies approach (e.g. Van Heteren et al., 1998; Neal and Roberts, 2000; Jol and Bristow, 2003; and Neal, 2004).

On September 2013, additional trenches (TP7 to TP10) were excavated seaward of the earlier pits to validate sedimentary structures revealed in the radar profiles and to collect sediments for grainsize analysis and to attempt Optically Stimulated Luminescence (OSL) dating of the sediments from either side of identified erosional unconformities. Sediments for luminescence dating were obtained following the publicly available sampling protocol of the Utah State University Luminescence Laboratory (Accessible online at http://www.usu.edu/geo/luminlab/how2osl.pdf). Opaque metal tubes were driven horizontally into the sediment units above and below the erosional contacts to obtain samples for luminescence dating. Sediments within $20-\mathrm{cm}$ radius surrounding the metal tubes were collected into a ziplock freezer bag for the measurement of the environmental dose rate. A total of five samples were sent to University of Cologne in Germany, for initial examination on the potential to use Optically Stimulated Luminescence (OSL) dating analysis (Table 5.3) for a chronology of past storm events.

\subsubsection{Luminescence dating}

A preliminary luminescence analysis was conducted on sample TP10 to test the suitability of the young volcaniclastic sediments for OSL dating. The sample was 
prepared following standard procedures for coarse grained samples, including (i) sieving to retrieve the $100-200 \mu \mathrm{m}$ fraction, (ii) treatment with $10 \% \mathrm{HCl}$ and $10 \%$ $\mathrm{H}_{2} \mathrm{O}_{2}$ to remove carbonates and organics, (iii) density separation using heavy liquid to extract quartz $\left(2.62-2.68 \mathrm{~g} / \mathrm{cm}^{3}\right)$ and potassium feldspar $\left(<2.58 \mathrm{~g} / \mathrm{cm}^{3}\right)$, and (iv) etching with $40 \% \mathrm{HF}$ for 40 minutes to remove the alpha irradiation affected rim of the quartz grains. The extracted quartz and potassium feldspar grains were then subjected to dose rate measurements using a standard blue-OSL SAR protocol in the case of quartz (Murray and Wintle, 2003) and a standard IR ${ }_{50}$ SAR protocol for the feldspar (Wallinga et al., 2000).

Table 5.3. List of samples for OSL Dating.

\begin{tabular}{|c|c|c|c|c|c|c|c|}
\hline$\#$ & $\begin{array}{c}\text { Sample ID } \\
\text { (field) }\end{array}$ & Long & Lat & $\begin{array}{l}\text { Depth from } \\
\text { surface, } m\end{array}$ & $\begin{array}{l}\text { Surface } \\
\text { Elevation } \\
\text { (msl), m }\end{array}$ & $\begin{array}{c}\text { Sample } \\
\text { Elevation } \\
\text { (msl), } m\end{array}$ & $\begin{array}{c}\text { Mean } \\
\text { grainsize, } \\
\mu \mathrm{m}\end{array}$ \\
\hline 1 & TP7-1 & 123.43 & 13.23 & $0.48-0.52$ & 2.083 & $1.56-1.60$ & 366.9 \\
\hline 2 & TP7-2 & 123.43 & 13.23 & $0.86-0.90$ & 2.083 & $1.18-1.22$ & 560.3 \\
\hline 3 & TP8 & 123.43 & 13.23 & $1.3-1.35$ & 3.08 & $1.73-1.78$ & 559.8 \\
\hline 4 & TP9 & 123.72 & 13.39 & $0.93-0.97$ & 2.242 & $1.27-1.31$ & 326.1 \\
\hline 5 & TP10 & 123.43 & 13.23 & $0.85-0.90$ & 1.785 & $0.88-0.93$ & 355.3 \\
\hline
\end{tabular}

\subsection{Results}

5.4.1. 2006 Typhoon Durian landscape changes and post-Durian modifications

Typhoon Durian has left prominent landscape changes that are visible on the satellite images taken before and after the storm (Fig. 5.4). The satellite imagery taken eight months prior to Typhoon Durian revealed a segment of the spit with extensively vegetated backshore with a treeline marking the dune crest (Fig. 5.4a). On the landward edge of the barrier spit are patches of mangrove along a meandering tidal channel. Six months after Typhoon Durian, the image showed minimal lateral shore 
erosion, but the spit was stripped of vegetation (Fig. 5.4b). Tongue- and fan-shaped surfaces, which indicate localized dune breaching were also prominent. On these breached portions of the dune, the depositional features ranged from isolated perched fans to closely spaced fans merged to form washover terraces.

The study is focused on the two most prominent breaching sites (Fig. 5.5). Narrow bands of light brown surfaces on the barrier spit visible on the September 2011 image (Fig. 5.5a) are accumulations of mud from a large fluvial flood caused by heavy rainfall with the July 2011 tropical storm Nock-ten (NASA, 2011). The mud line, which approximates the upper limit of standing flood levels, indicates that the washover fan surfaces were most probably submerged during the flood. On the other hand, the higher portions of the barrier dune have not been flooded, and were most likely minimally disturbed. The washover fans and terraces are bounded on the sides by either a gentle topographic rise to steep scarps of the unbreached portions of the dune called pedestals. These pedestals typically stand at 3 to $4 \mathrm{~m}$ above sea level (asl) are remnants of the pre-storm dune elevation (Fig. 5.5b). A transect parallel to the coast shows the dune pedestals rising above washover fans and terraces, which are at much lower elevations between 1.5 to $2.5 \mathrm{~m}$ across the breached portions (Fig. 5.5c). The elevations of the pedestals and washover fans suggest that the inundation level must be higher than $1.5 \mathrm{~m}$ but likely did not exceed $3 \mathrm{~m}$.

The sedimentology was investigated along two shore normal transects. But the detailed washover stratigraphy will only be presented for the southern fan containing trenches TP4 to TP8. This is because compared to the northern fan; the southern fan has not been significantly modified post-deposition by the tidal channel. 


\subsubsection{Stratigraphy on the washover fan}

The transect on the southern fan reveals a sequence of laminated coarse-grained sands deposited by the breaching-related overwash of Typhoon Durian (Fig. 5.6). Most proximal to the shore, TP8 shows a planar-laminated coarse sand unit that exhibit little significant vertical variation in grainsize except at the depth between 1 to $1.2 \mathrm{~m}$ from the surface where a discrete 10-cm thick gravelly layer is found (Fig. 5.6a). Moving inland, the walls of trenches TP7, TP6 and TP 5 consistently show a sequence of pre-Durian sand, overlain by the Durian washover sand, and capped by a muddy sand. In TP7 the pre-Durian stratigraphy is composed of two sand units that are separated by a gently dipping, $3 \mathrm{~cm}$-thick bed of black sand. The lower sand unit (pre-TD2) contains coarse sand ( 0 to $-1 \phi)$. The upper sand unit (pre-TD1) contains mostly fine to medium sand, no coarser than $1 \phi$, that exhibits thin planar to slightly undulating laminations. The upper part of the pre-TD1 sand unit, contains laminae that are truncated highlighting a sharp contact that separates it from the overlying coarser sand unit interpreted as the Durian washover (Fig. 5.6b). The Durian washover deposit (TD) is identified as a $35 \mathrm{~cm}$ thick laminated gravel basal layer (40$60 \%$ gravel) that grades into a laminated coarse sand towards the top. Unlike in TP7, the Durian washover deposit (TD) inland at TP6 and TP5 is much thinner at about 12 to $15 \mathrm{~cm}$ thick (Fig. 5.6c-d), and mostly coarse sand containing discrete thin layer of gravel $(<10 \%$ gravel). Though the sedimentology is similar the sequence in TP5 shows a slight contrast where a $3 \mathrm{~cm}$ thick grayish brown medium sand marks the sharp boundary between the darker colored pre-Durian sand (pre-TD1) and the lighter colored Durian washover sand (TD). Grass roots penetrate into the Durian washover sand obscuring the apparent lamination. At the terminus of the washover fan, the washover deposit in trench TP4 can be as thick as $60 \mathrm{~cm}$ and exhibit prominent 


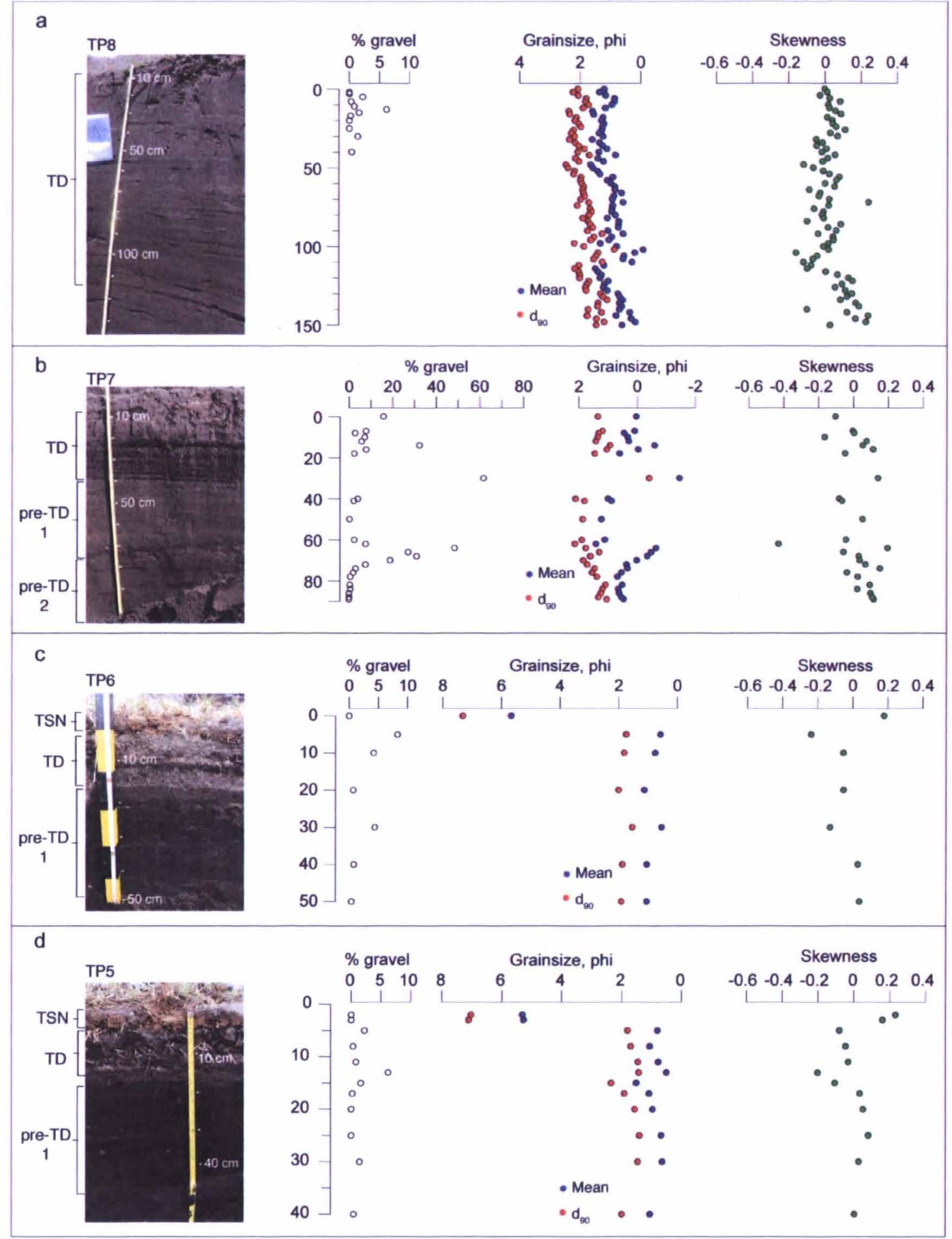

Figure 5.6. Stratigraphy and vertical textural variation of the sedimentary units revealed in trenches TP8 (a), TP7 (b), TP6 (c) and TP5 (d) located on the southern washover fan. 

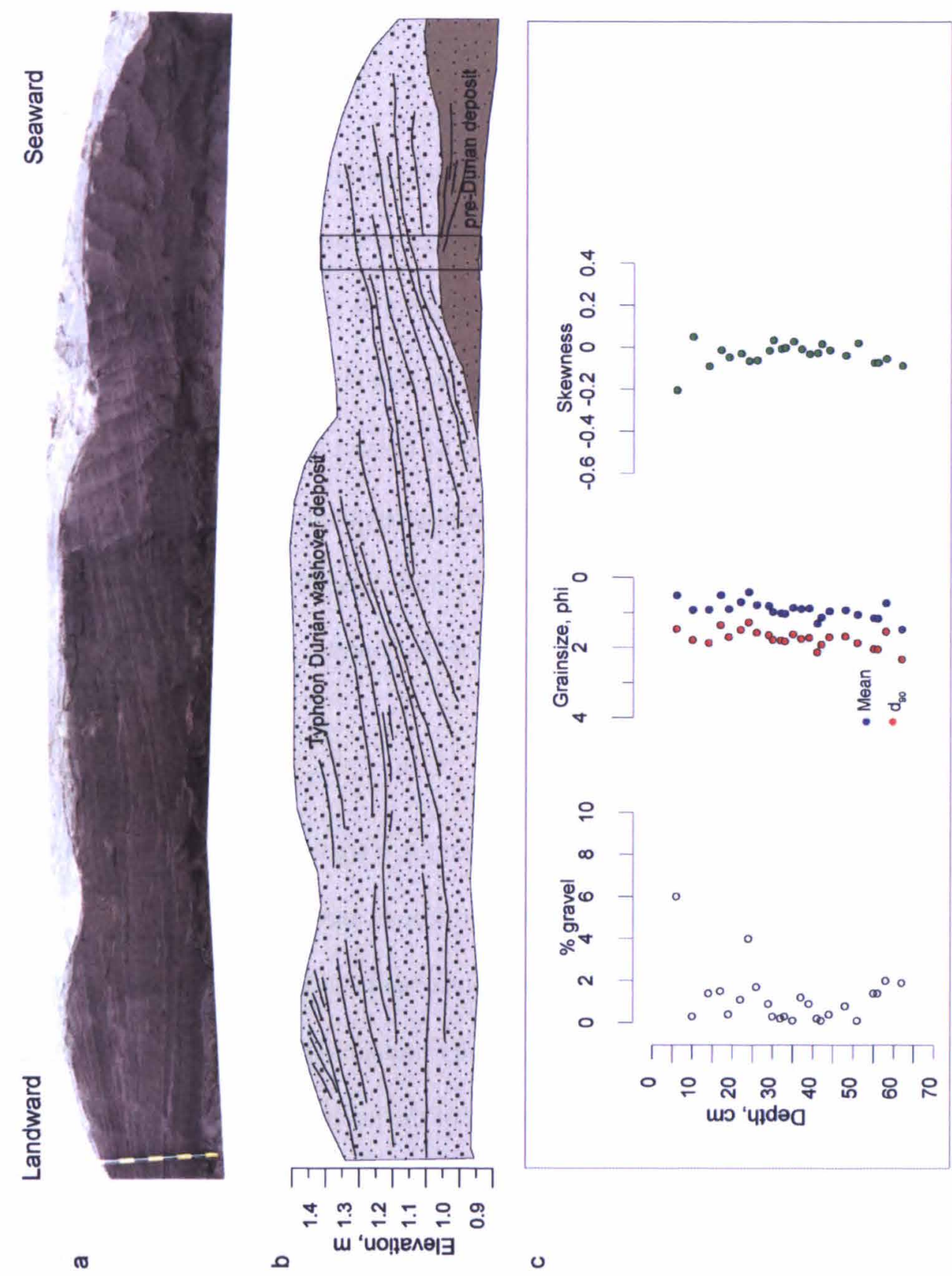

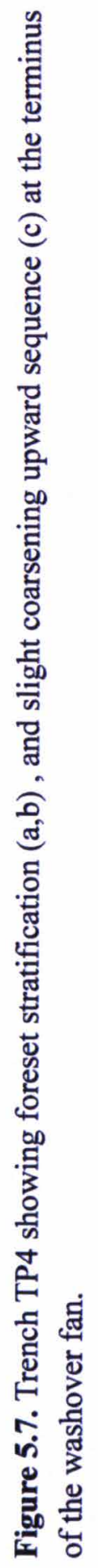


foreset stratification (Fig. 5.7). The foresets dip at angles ranging from $14^{\circ}$ to $22^{\circ}$. Discrete very coarse-grained laminae contain about 4 to 6 percent gravel. A $5 \mathrm{~cm}$ thick, brown mud caps the Durian washover deposit in trench TP7, TP6 and TP5. This mud unit most likely corresponds to the flood deposit of the July 2011 tropical storm Nock-ten.

\subsubsection{Vertical and lateral textural trends of the washover deposit}

The Typhoon Durian washover deposits on the southern washover fan exhibit both fining and coarsening upward sequence (Fig. 5.6 \& 5.7). Trench TP8, TP7 and TP5 exhibit fining upward trends with mean grain size at the base ranging between $-2 \phi$, (granule) to $1 \phi$ (coarse sand), grading to $0.5 \phi$ (coarse sand) to $1.5 \phi$ (medium sand) towards the top. This fining upward trend is accompanied by a generally high gravel component ( $6 \%$ to as high as $60 \%$ in TP7) at the base of the Durian washover deposit, and then decreases towards the top. In contrast, trench TP6 and TP4 show coarsening upward trends.

The erosional base and the mud cap unit on top were used as stratigraphic boundaries to constrain the thickness of the washover deposit across the washover fan (Figs 5.6 to 5.8). At trench TP8, the washover deposit can be as thick as $1 \mathrm{~m}$. In TP7 the washover deposit is about $30 \mathrm{~cm}$. A slightly thinner deposit was found in TP6 (15 $\mathrm{cm})$ and in TP $5(10 \mathrm{~cm})$. At the terminus of the fan in TP4, the washover deposit was up to $60 \mathrm{~cm}$ thick. The deposit thickness, however, does not necessarily correspond to the deposition directly associated with Typhoon Durian, but most likely represent the cumulative effect of post-depositional changes such as erosion at the terminus of the fan by tidal action, or beach recovery near the shore by swash action. In contrast to 
a
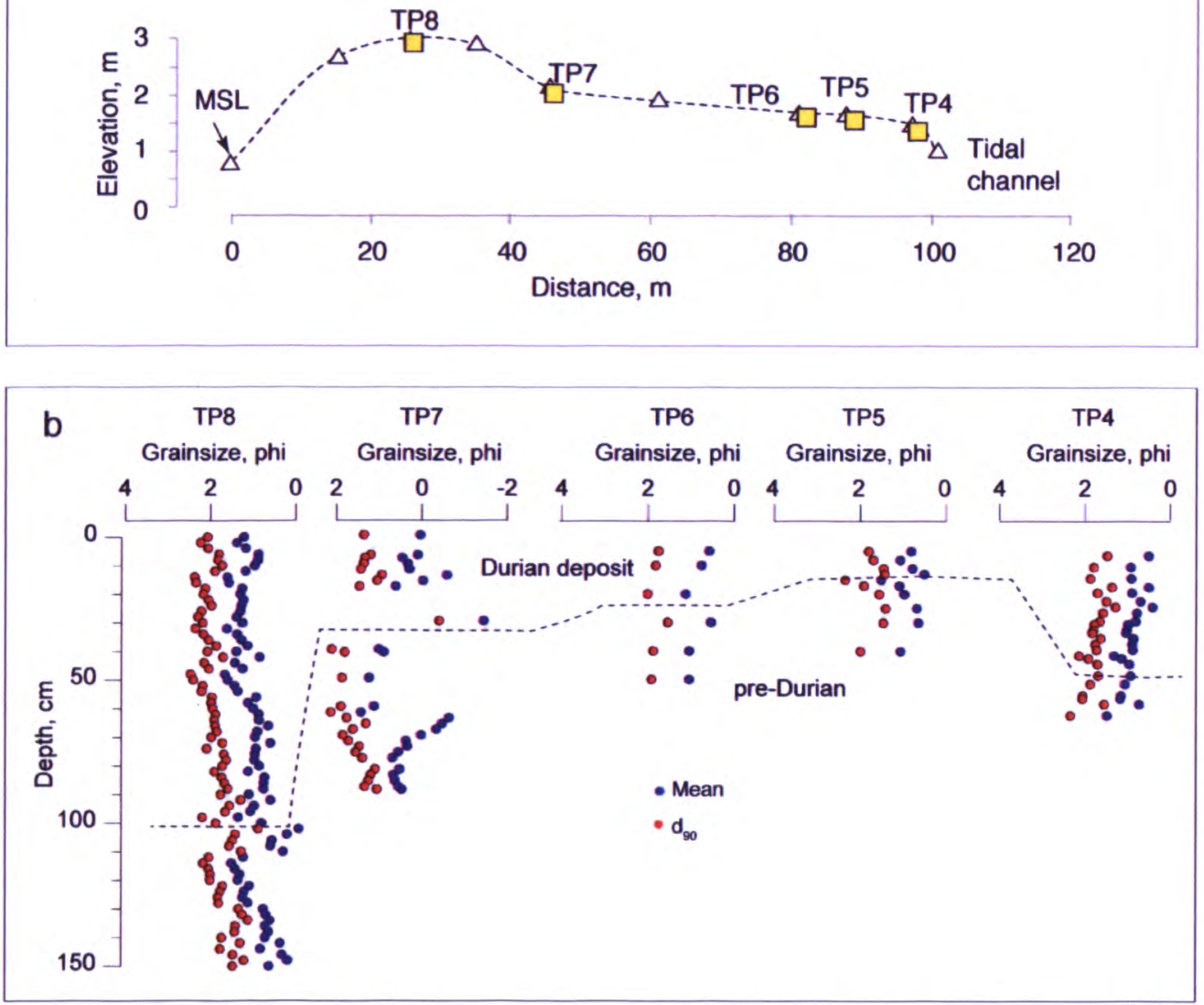

Figure 5.8. Across-shore profile (a) and lateral variation in thickness and grainsize (b) of the Typhoon Durian washover deposit on the southern washover fan. 
the highly variable thickness, bulk sediment mean and $d_{90}$ grainsize show an overall fining landward trend of the washover deposit near the shore at TP8 towards the fan terminus at TP4 (Fig. 5.8).

\subsubsection{Sediment source of the Typhoon Durian washover deposit}

A comparison of the textural characteristics of the grab samples from the beach face, berm, dune and tidal channel reveals that moderately sorted, medium to coarse sands are readily available for transport in the barrier spit system (Fig. 5.9). The sediments on the beach face are relatively finer compared to the inland berm, dune and tidal channel sediments. The coarsest sediments are found on the berm.

The mean grain size and sorting of the washover deposits are more similar to the coarser sediments found in the berm, dune and tidal channel. The washover deposits were most probably sourced from the locally breached part of the dune. There is very little gravel in the dune sediments and the abundance of gravel components in the washover deposits imply an additional contribution from other sources. Such sediments would need to be fairly high energy suggesting a likely source would be the shoreface or swash zone.

\subsubsection{Ground penetrating radar profiles}

A shore-normal GPR profile on the southern washover fan reveals a combination of dipping, sub-horizontal, and horizontal reflections (Fig. 5.10). Seaward dipping reflections (apparent dip: 20 to $25^{\circ}$ ) occur from the beach until $20 \mathrm{~m}$ inland. Beyond $20 \mathrm{~m}$ the reflectors merge with initially shallow, sub-horizontal to landward dipping $\left(<10^{\circ}\right)$ reflections, and subsequently with predominantly horizontal reflections extending landwards to the edge of the tidal channel. At least three steep, shoreward 


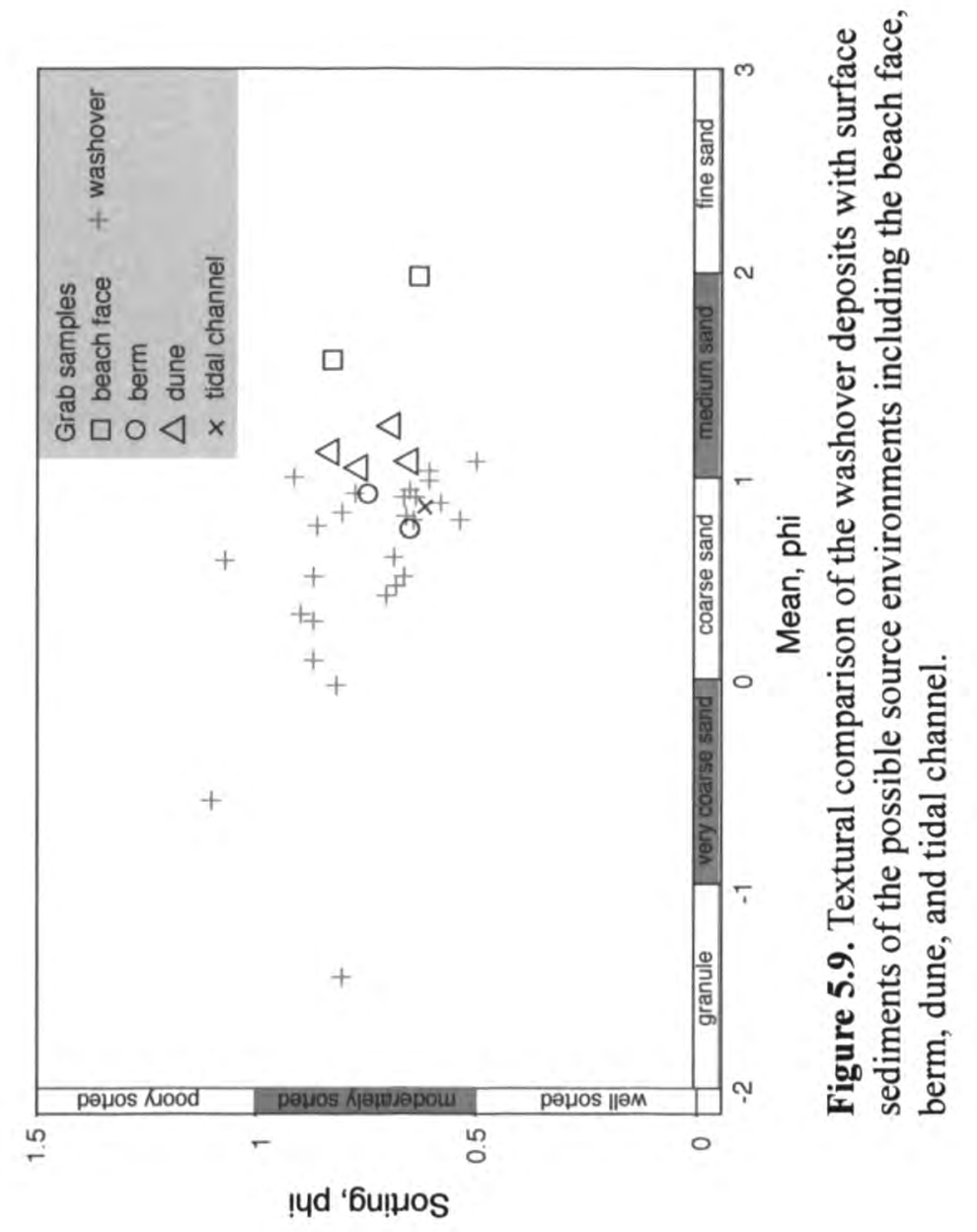




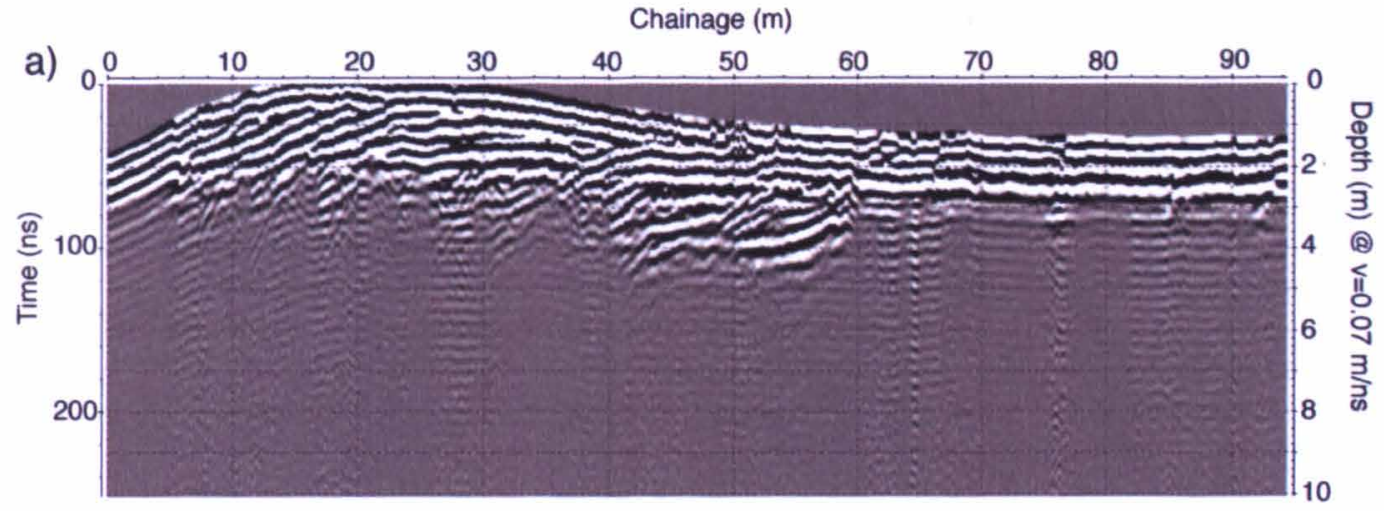

Chainage $(m)$

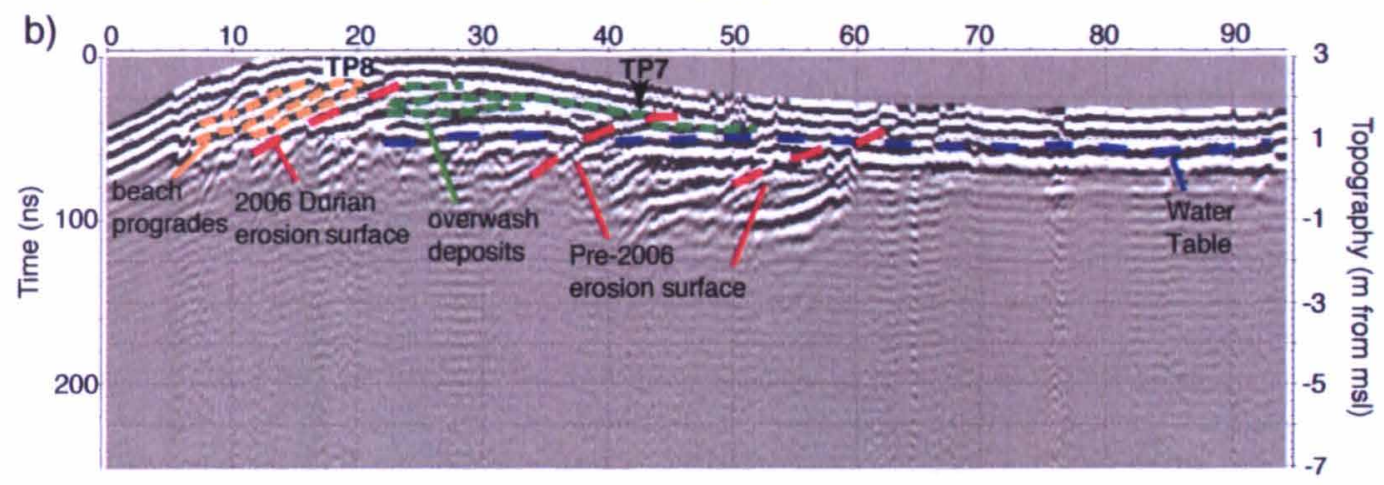

c)

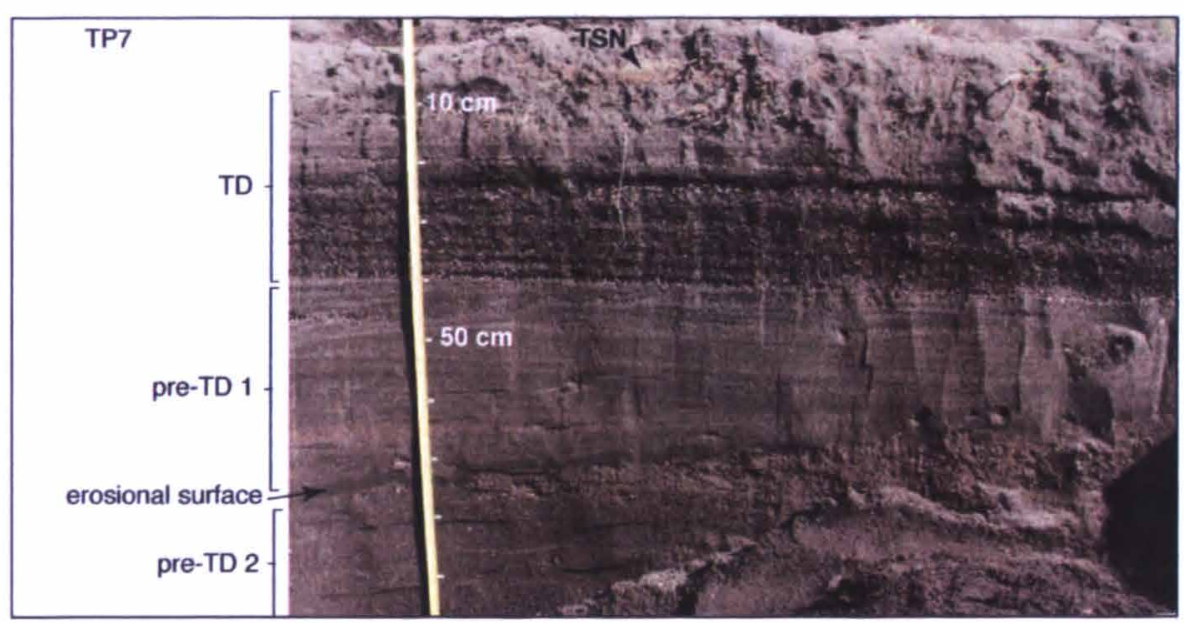

Figure 5.10. Internal stratigraphy across the southern washover fan revealed on a GPR profile, presented here as processed and topographically corrected section (a) and interpreted section (b). Trench TP7 (c) validates the erosional surface identified on the GPR profile to be pre-Durian. The erosional surface separates two pre-Durian sand units (pre-TD1 and pre-TD2). TD corresponds to the Typhoon Durian washover deposit. TSN corresponds to the mud deposit of tropical storm Nock-ten. 
dipping reflections (apparent dip: 15 to $30^{\circ}$ ) subsequently truncate the sub-horizontal to horizontal reflections across the barrier spit. Trench TP7 taken through one of the prominent seaward dipping reflections revealed a seaward, gently dipping (apparent dip: $10^{\circ}$ ) feature at depths between 60 to $70 \mathrm{~cm}$ from the surface. The seaward dipping feature is marked by a $3 \mathrm{~cm}$ thick black magnetite sand that truncates planarlaminated sand and gravelly sand units below, which indicate that it is an erosional surface. Above the erosional surface the sequence consists of the pre-2006 Durian laminated sand unit, overlain by the 2006 Durian laminated gravelly to coarse sand washover deposit, and capped by the 2011 tropical storm Nock-ten muddy flood deposit.

Other miscellaneous reflections identified in the profile include air and ground waves and water table. The continuous double reflection at the top of the GPR profile corresponds to the air and ground waves. Another continuous, horizontal reflection at $\sim 2 \mathrm{~m}$ depth represents the freshwater table. Reflections are strongly attenuated below $3 \mathrm{~m}$ depth. Attenuation of the electromagnetic radar signal by saltwater is a common issue in low-lying coastal settings.

The GPR profile on the northern washover terrace displays reflection patterns nearly similar to that on the southern washover fan (Fig. 5.11). Seaward dipping reflections (apparent dip: 25 to $30^{\circ}$ ) dominate within $20 \mathrm{~m}$ from the beach. The reflections dip gently landwards (apparent dip: $10^{\circ}$ ) between $20 \mathrm{~m}$ and $40 \mathrm{~m}$, and then join with subhorizontal to horizontal reflections throughout the remainder of the transect. Trench TP10 taken through the prominent seaward dipping reflections at $20 \mathrm{~m}$ from the shore revealed a seaward, steeply dipping (apparent dip: 20 to $30^{\circ}$ ) feature at depths 

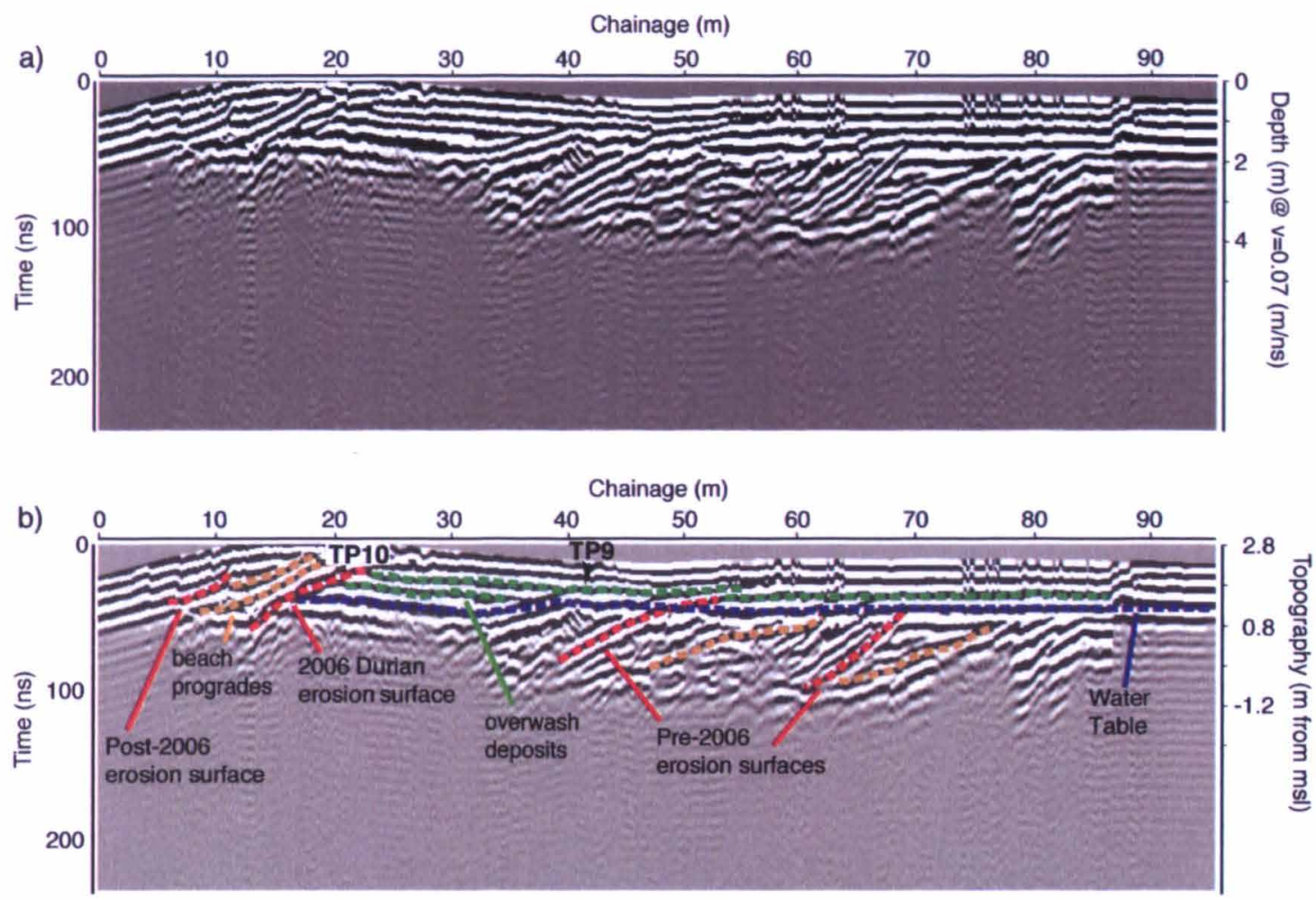

c)

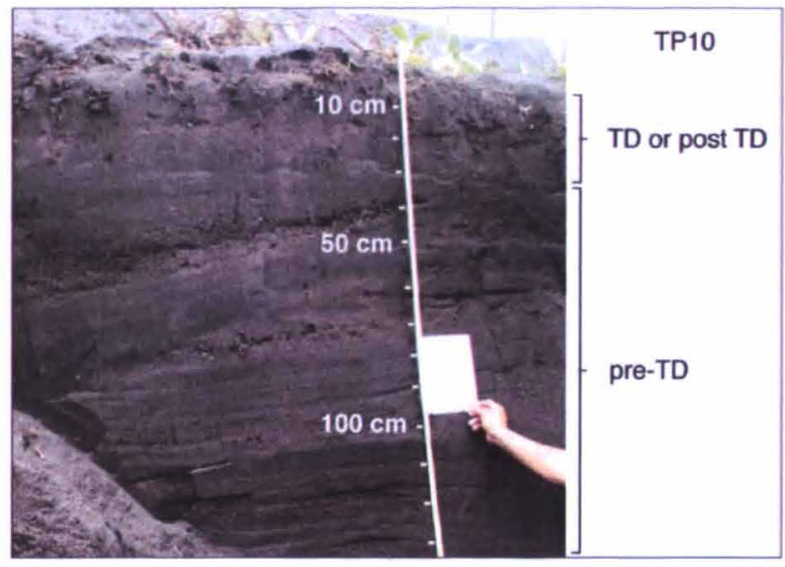

Figure 5.11. Internal stratigraphy across the northern washover fan revealed on a GPR profile, presented here as processed and topographically corrected section (a) and interpreted section (b). Trench TP10 (c) validates the erosional surface identified on the GPR profile to be associated with Typhoon Durian. The erosional surface truncates horizontally laminated pre-Durian sand unit (pre-TD). The sand unit above the erosional surface most likely correspond to the Durian washover deposit (TD) including newly accreted sediments during post-Durian beach recovery (post-TD). 
between 40 to $50 \mathrm{~cm}$ from the surface, which is bounded above and below by laminated sand and gravelly units. The seaward dipping feature is marked by a black magnetite sand unit, which varies in thickness from $10 \mathrm{~cm}$ to $4 \mathrm{~cm}$ and truncates planar-laminated sand and gravelly sand units below. This is consistent with the erosional nature of the seaward dipping surface in trench TP7. A wedge-like gravelly sand unit ( $\sim 50 \%$ gravel) sits immediately above the erosional surface. The gravelly sand unit gradually transitions to laminated sand and then to unstratified sand units towards the top.

\subsubsection{Chronological control}

Although measured on large aliquots with 8-mm diameter (equivalent to $\sim 1000$ quartz or feldspar grains, and the largest aliquot size that can be measured), the luminescence signals of both minerals appeared to be extremely weak (Fig. 5.12). Most aliquots did not show any visible response to laboratory stimulation even after the application of relatively large laboratory doses of 10-30 Gy. Only some of the quartz and feldspar aliquots revealed visible signal curves (Figs 5.12a,b), but these are extremely dim and hardly distinguishable from background scatter in case of the feldspars (Fig. 5.12b). In addition to the dim signals, quartz also yielded an unstable and slowly bleaching medium component (Fig. 5.12a). As a consequence, the corresponding dose-response curves are associated with large fitting error due to signal scatter indicating very high uncertainties $($ Fig. $\mathbf{5 . 1 2 c , d})$. The combined very low recycling ratios and recuperation do not fulfill the reproducibility and recuperation criteria, which are a prerequisite for reliable dating. In the absence of precise chronological control, the 2006 Typhoon Durian washover deposit can however be used as a stratigraphic marker. The ages of the erosional surfaces and 
a)

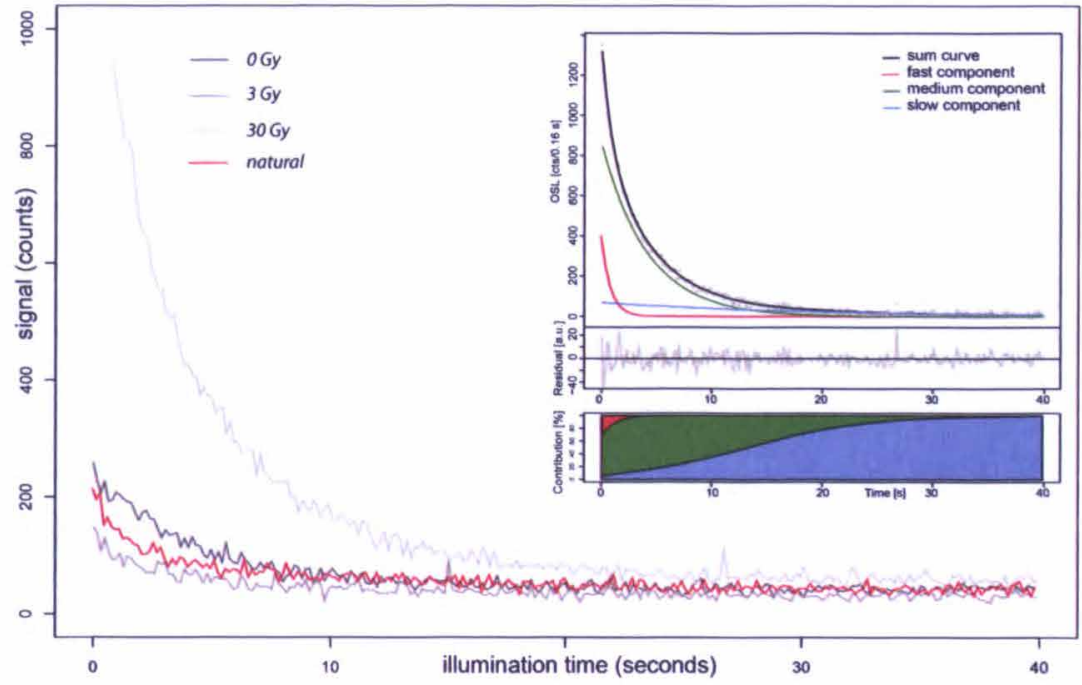

b)

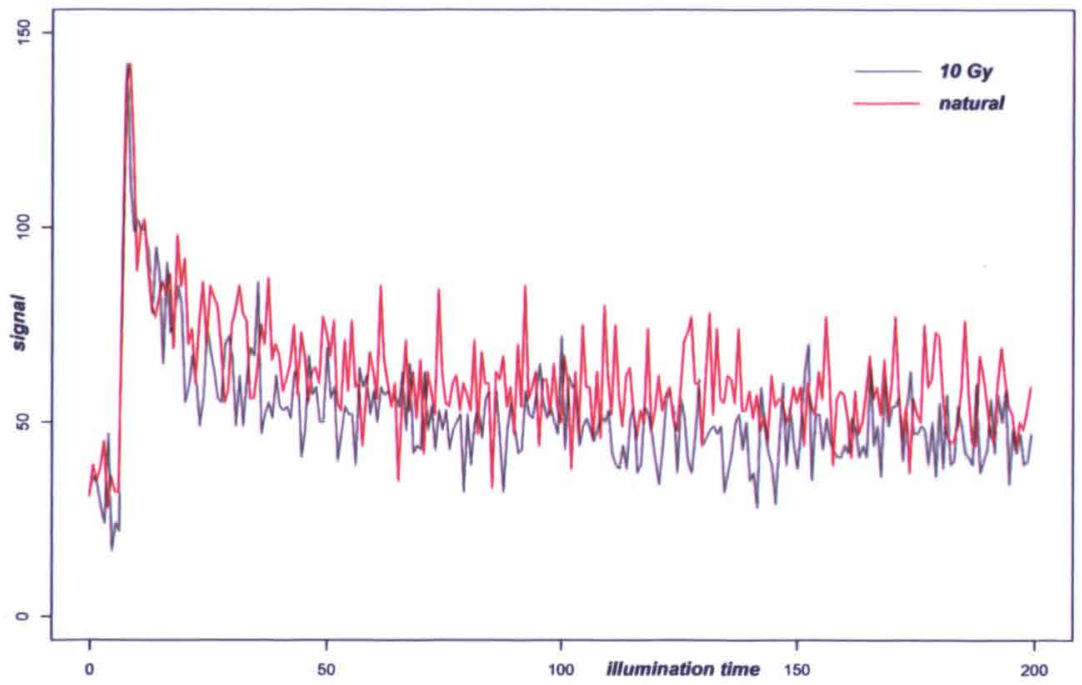

c)
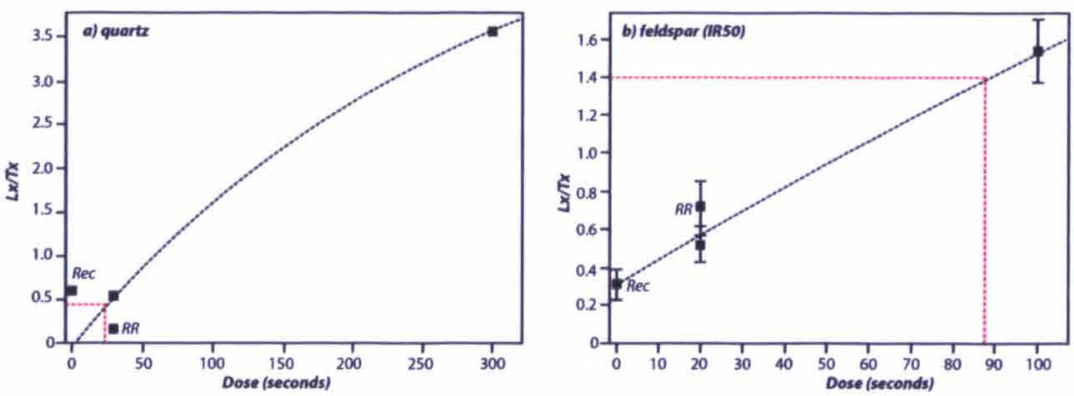

Figure 5.12. OSL signals of the sediment sample in trial pit TP7-1.

a) Decay curves of the natural (red) and regenerated (grey) quartz show weak and scattered luminescence signals and fitting of the signal curves (inset) points to a strong influence of slowly bleaching and unstable medium component.

b) Decay curves of the natural (red) and regenerated (grey) IR50 feldspar luminescence signals.

c) Dose-response curves for quartz and feldspar. 
remaining sediment units will be defined relative to their stratigraphic relation to the Durian washover deposit.

\subsection{Discussion}

\subsubsection{Geomorphologic imprints of coastal inundation and their preservation}

This study demonstrates and further reinforces the concept that in cases when in-situ instrumentation and immediate post-typhoon surveys are limited or non-existent, geomorphologic investigations of the erosional and depositional features can augment information gaps on inundation levels. A series of pre- and post-Durian images further aid in identifying possible landscape modifications before the actual field survey such as the July 2011 tropical storm Nock-ten flooding. The relatively good preservation of the erosional and depositional imprints of Typhoon Durian on the Malinao spit implies a preservation potential of nearly 7 years on this coastline is possible. The preservation potential of 7 years, however, is still very short. In certain areas, relict or inactive washover fans on the west-central Florida barrier coast remained recognizable on aerial photographs even after 30 to 40 years (Sedgwick and Davis, 2003).

Typhoon tracks from local and international weather agencies show no record of a landfalling typhoon at or near Lagonoy Gulf following Typhoon Durian until the end of 2013, except for tropical storm Nock-ten. This tropical storm brought heavy rainfall resulting in extensive floods (NASA, 2011; Salaverria, 2011) but not enough strong winds to generate storm surge capable of overtopping the previously lowered breached potions of the spit. Furthermore, there was neither geomorphic indicator nor first-hand account of barrier washout during the flood. In fact, even after the tropical storm Nock-ten flood, the washover fans remained recognizable on the satellite 
images. This period of relative typhoon quiescence perhaps aided in the preservation of the geomorphic imprints of inundation in Malinao.

\subsubsection{Storm surge history reconstructed from sediment record}

The Typhoon Durian washover deposit has a distinct sediment signature of a sharp erosional base overlain by coarse-grained unit composed of either coarse to very coarse sand or gravel. A similar trend of abrupt textural coarsening of the sediments, which represent the onset of tropical cyclone-induced inundation and sedimentation within the frontal beach ridge, has been observed along the northeast coast of Australia (Nott et al., 2013). This textural signature has been useful to constrain stratigraphic boundaries within the barrier spit sediment sequence containing fairly homogenous components.

The Typhoon Durian washover deposit also exhibit notable planar horizontal laminations, which then terminate into foreset laminations at the landward terminus of the fan. These internal stratifications are similar to the generalized washover stratigraphy, and the foreset laminae indicate subaqeous deposition when the overwash enters into the tidal channel (Sedgwick and Davis, 2003). Although the washover deposit does not exhibit consistent vertical textural trends across the fan, there is a discernable overall fining trend towards the terminus of the fan (Fig. 5.8). Landward fining trend is typically attributed to the diminishing flow of the surge across the fan towards the terminus (Leatherman and Williams, 1977). 
The two shore-normal GPR profiles consistently show at least three seaward-dipping prominent reflections, which were confirmed at two locations as erosional surfaces. The seaward most erosional surface corresponds to 2006 Typhoon Durian, while the two erosional surfaces inland were most probably sustained from earlier similarly intense landfalling typhoons. Prior to Durian, other intense typhoons have generated storm surge in Lagonoy Gulf including the 1987 Nina, 1960 Kit and 1959 Harriet

(Fig. 5.2). The storm surge of Typhoon Nina exceeded $2 \mathrm{~m}$ in Tabaco City to as high as $\sim 7 \mathrm{~m}$ in the town of Tiwi (PAGASA, 2000). The storm surges associated with typhoons Kit and Harriet are unknown. At this point, we cannot determine for certain whether the older dune erosion or breaching events were caused by these typhoons due to the absence of accurate chronological constraints on the erosional surfaces.

Unfortunately, this study also highlights the challenge of obtaining chronological control on coarse, volcaniclastic sediment systems. OSL-dating failed to produce age dates for the sedimentary units bounding the erosional surfaces. Both quartz and feldspar grains yielded extremely dim signals owing to either their volcanic origin or perhaps incomplete bleaching (Kolstrup, 2007; Davids et al., 2010). Aside from the weak quartz and feldspar signals for effective OSL-dating, fine-grained or organicrich sediments are also not available for alternative age-dating techniques such as radiocarbon dating or ${ }^{210} \mathrm{~Pb}$.

\section{Conclusions}

Typhoon Durian generated a storm surge that caused significant erosion and breached segments of the Malinao barrier sand spit in central eastern Philippines. Satellite imagery in September 2011 showed signs of beach recovery but the geomorphological indications of the inundation were still evident and were 
successively studied in 2012 and 2013. Remnants of the pre-storm dune profile have elevations ranging from 3.5 to $4 \mathrm{~m}$, which imply that breaching might have resulted from inundation higher than $1.5 \mathrm{~m}$ but not exceeding $3 \mathrm{~m}$. The typhoon washover deposit resembles the typical washover fan stratigraphy, and exhibits horizontal to sub-horizontal lamination on the front to mid-fan and foreset stratification at the fan terminus. The Durian washover deposit has sharp, erosional base marked by abrupt coarsening of the sediments. Shore-normal GPR transects reveal at least two buried erosional surfaces farther inland of the erosional surface of Typhoon Durian. Similar to Durian, the older erosional surfaces were probably formed from previous typhoons. But because of limited datable materials, the timing of the erosional surfaces remain unknown, highlighting the persisting challenge of obtaining chronological control on coarse, volcaniclastic sediments.

\section{Acknowledgement}

This research was supported by the Singapore National Research Foundation fellowship scheme (Grant No: NRF-RF2010-04) and the Singapore Government Ministry of Education in supporting Earth Observatory of Singapore to complete this work. This is EOS Contribution No. XX. We thank German Gonzaga of the Malinao Local Government Unit who helped us access the study area. We thank Mr. Raul Capistrano on behalf of NAMRIA for facilitating the access to the tide gauge data. We are grateful to Joan Reotita, Ronald Lloren, Yo Muan, Lester Valle,Arlene Tengonciang, Ariel Malonda, Antonio Ceres and Elmer Cas for their generous help in collecting field data. 


\section{References}

Alojado, D., and Padua, D.M.V., 2015. Strongest typhoons in the Philippines (19472014). Accessed on 25 June 2016. (Available online at http://www.typhoon2000.ph/stormstats/WPF_StrongestTyphoonsPhilippines 2015Ed.pdf.)

Andal,E.S., Yumul, G.P. Jr., Listanco,E.L., Tamayo,R. A. Jr., Dimalanta, C.B., and Ishii, T., 2005. Characterization of the Pleistocene volcanic chain of the Bicol Arc, Philippines: implications for geohazard assessment. TAO 16 (4), 865883.

Blott, S.J. and Pye, K., 2001. GRADISTAT: a grain size distribution and statistics package for the analysis of unconsolidated sediments. Earth Surface Processes and Landforms 26, 1237-1248.

Buynevich, I.V., Fitzgerald, D.M. and Van Heteren, S., 2004. Sedimentary records of intense storms in Holocene barrier sequences, Maine, USA. Marine Geology $210,135-148$.

Buynevich, I. V., FitzGerald, D. M., \& Goble, R. J. (2007). A $1500 \mathrm{yr}$ record of North Atlantic storm activity based on optically dated relict beach scarps. Geology 35(6), 543-546.

Castillo, P. R., and C. G. Newhall, 2004: Geochemical constraints on possible subduction components in lavas of Mayon and Taal volcanoes, Southern Luzon, Philippines. Journal of Petrology 45, 1089-1108.

Cunningham, A. C., Bakker, M. A., van Heteren, S., van der Valk, B., van der Spek, A. J., Schaart, D. R., \& Wallinga, J. (2011). Extracting storm-surge data from coastal dunes for improved assessment of flood risk. Geology 39(11), $1063-$ 1066.

Davids, F., Duller, G.A.T., and Roberts, H.M., 2010. Testing the use of feldspars for optical dating of hurricane overwash deposits. Quaternary Geochronology 5 , $125-130$

Divis, A. F., 1980: The petrology and tectonics of recent volcanism in the central Philippine Islands. AGU Geophysical Monograph Series 23, 127-124.

Ettinger, S., Manville, V., Kruse, S., \& Paris, R. (2014). GPR-derived architecture of 
a lahar-generated fan at Cotopaxi volcano, Ecuador. Geomorphology 213, 225-239.

Folk, R.L., W.C. Ward. 1957. Brazos River bar: a study in the significance of grain size parameters. Journal of Sedimentary Petrology 27, 3-26.

Jol, H.M., Bristow, C.S., 2003. GPR in sediments: advice on data collection, basic processing and interpretation, a good practice guide. In: Bristow, C.S., Jol, H.M. (Eds.), Ground Penetrating Radar in Sediments. Geological Society London Special Publication 211, 9-27.

Knittel-Weber, C., and U. Knittel, 1990: Petrology of the volcanic rocks on the eastern flank of Mount Malinao, Bicol Arc (S. Luzon, Philippines). Journal Southeast Asian Earth Sciences 4, 267-280.

Kolstrup, E., 2007. OSL dating in paleoenvironmental reconstructions. A discussion from a user's perspective. Estonian Journal of Earth Sciences 56 (3), 157-166.

Leatherman, S.P., 1981. Overwash processes. Benchmark papers in Geology, Vol. 58. Hutchinson Ross Publishing Co., USA. 376 pp.

Leatherman, S.P., Williams, A. T., 1977. Lateral textural grading in overwash sediments. Earth Surface Processes 2, 333-341.

Lindhorst, S., Betzler, C., \& Hass, H. C. (2008). The sedimentary architecture of a Holocene barrier spit (Sylt, German Bight): Swash-bar accretion and storm erosion. Sedimentary Geology 206(1), 1-16.

Loy, K.C., Sinha, P.C., Liew, J., Tangang, F., and Husain, M.L. 2010. Modeling storm surges associated with super typhoon Durian in South China Sea. Natural Hazards. DOI 10-1007/s11069-010-9674-7.

Møller, I. and Anthony, D., 2003. GPR study of sedimentary structures within a transgressive coastal barrier along the Danish North Sea coast. In: Groundpenetrating Radar in Sediments (Eds C.S. Bristow and H.M. Jol). Geological Society London Special Publication 211, 55-67.

Morton, R.A., 2002. Factors controlling storm impacts on coastal barriers and beaches - a preliminary basis for real-time forecasting. Journal of Coastal Research 18, 486-501. 
Morton, R.A., and Sallenger Jr., A. H., 2003. Morphological impacts of extreme storms on sandy beaches and barriers. Journal of Coastal Research 19 (3), 560-573.

Ozawa, A., Tagami, T., Listanco, E. L., Arpa, C. B., and Sudo, M. 2004: Initiation and propagation of subduction along the Philippine Trench: evidence for the temporal and spatial distribution. Journal of Asian Earth Sciences 23, 105111.

National Aeronautics and Space Administration (NASA). 27 July 2011. NASA measures heavy rain in tropical storm Nock-ten over Philippines. Accessed online 10 April 2012. Available online at [http://www.nasa.gov/mission_pages/hurricanes/archives/2011/h2011_Nockten.html].

Neal, A., 2004. Ground-penetrating radar and its use in sedimentology: principles, problems and progress. Earth-Science Reviews 66, 261-330.

Neal, A., Roberts, C.L., 2000. Applications of ground penetrating radar (GPR) to sedimentological, geomorphological and geoarchaeological studies in coastal environments. In: Pye, K., Allen, J.R.L. (Eds.), Coastal and Estuarine Environments: Sedimentology, Geomorphology and Geoarchaeology, Geological Society of London Special Publications 175, 139-171.

Nott, J. 2006. Extreme events: a physical reconstruction and risk assessment. Cambridge University Press. 297 pp.

Nott, J., Chague-Goff, C., Goff, J., Sloss, C., Riggs, N., 2013. Anatomy of sand beach ridges: evidence from severe Tropical Cyclone Yasi and its predecessors, northeast Queensland, Australia. Journal of Geophysical Research: Earth Surface 118, 1710-1719.

Nott, J. and Hubbert, G., 2005. Comparisons between topographically surveyed debris lines and modeled inundation levels from severe tropical cyclones Vance and Chris, and their geomorphic impact on the sand coast. Australian Meteorological Magazine 54, 187-196. 
Padua, D.M.V., 2008. 29 Most intense typhoons of Bicol Region, Philippines.

Accessed on 25 June 2016. (Available online at http://www.typhoon2000.ph/25mostb.htm.)

Salaverria, L., 27 July 2011. Tropical storm 'Juaning' slams Bicol provinces; 9 killed. Inquirer Southern Luzon, Philippine Daily Inquirer. Accessed on 10 April 2012. Available online at [http://newsinfo.inquirer.net/30793/tropical-storm'juaning'-slams-bicol-provinces-9-killed].

Sedgwick, P. E., Davis. R. A. Jr., 2003. Stratigraphy of washover deposits in Florida: implications for recognition in the stratigraphic record. Marine Geology 200, $31-48$.

Soria, J.L.A., Switzer, A.D., Villanoy, C.L., Fritz, H.M., Bilgera, P.H.T., Cabrera, O.C., Siringan, F.P., Yacat-Sta. Maria, Y., Ramos, R.D., Fernandez, I.Q., 2016. Repeat storm surge disasters of Typhoon Haiyan and its 1897 predecessor in the Philippines. Bulletin of the American Meteorological Society 97(1), 31-48.

Switzer, A.D., 2013. Measuring and analyzing particle size in a geomorphic context. In: Shroder, J. (Editor in Chief), Switzer, A.D., Kennedy, D.M. (Eds.), Treatise on Geomorphology. Academic Press, San Diego, CA, vol. 14, Methods in Geomorphology, pp. 224-242.

Switzer, A.D., Bristow, C.S., and Jones, B.G., 2006. Investigation of large-scale washover of a small barrier system on the southeast Australian coast using Ground Penetrating Radar. Sedimentary Geology 183(1), 145-156.

Wang, P., and Horwitz, M.H., 2007. Erosional and depositional characteristics of regional overwash deposits caused by multiple hurricanes. Sedimentology 54 , $545-564$.

Williams, H.F.L., 2015. Contrasting styles of Hurricane Irene washover sedimentation on three east coast barrier islands: Cape Lookout, North Carolina; Assateague Island, Virginia; and Fire Island, New York. Geomorphology 231, 182-192. 


\section{Chapter 6}

\section{Synthesis}

Typhoon Haiyan tragically attests to the vulnerability of Philippine coasts to storm surge hazard. It also highlighted the limited and patchy knowledge that exists on the impacts to immediately affected communities despite the high frequency of storm surges in the archipelago. Moving forward, this dissertation contributes to increasing the level of local and regional science-based knowledge by laying down groundwork on the geologic investigations of storm surge impacts in the Philippines. Two recent storm events namely the 2006 Typhoon Durian (Reming) and the 2013 Typhoon Haiyan (Yolanda) provided an opportunity to study the geomorphic and sedimentologic imprints of storm surges and the resulting coastal overwash.

This dissertation though primarily built upon a geological framework of storm surge has benefited considerably from the integration of multiple disciplines including meteorology, oceanography, coastal engineering, and history (Switzer et al., 2014). Overall, the multi-disciplinary approach led to (1) local understanding of storm surge dynamics and the factors affecting the spatial variation of amplification leading to inundation overland; (2) characterization of the onshore geomorphic and sediment imprints within the bounds of hydrodynamic conditions and sediment transport processes; and (3) historicallyoriented investigation of storm surge heights and the geologic impacts to the coasts near typhoon landfalls. In this chapter, the key results of this study are 
highlighted, limitations are recognized, and finally potential future studies are identified.

\subsection{Key Results}

In retrospect, the historical record reveals an unnamed typhoon on 12 October 1897 October a typhoon that is now noted as a predecessor to Typhoon Haiyan. The typhoon referred here as Ty 1897 took a similar path of destruction through the eastern central Philippines. In contrast to the almost identical typhoon tracks, Typhoon Haiyan differs from Ty 1897 in several ways. Haiyan was more intense, had larger maximum wind coverage, and moved faster than Ty 1897. The comparative study between Typhoon Haiyan and Ty 1897 reveals that Typhoon Haiyan's storm surge was about twice the height of the 1897 event in San Pedro Bay, but the two storm surges had similar heights on the open Pacific coast (Soria et al., 2016; Chapter 2). One of the key elements to this comparative study is the availability of a reliable historical post-typhoon technical report of Ty 1897 which provided essential information such as typhoon track, barometric readings, photos of damage and coastal impacts, and somewhat uniquely the spatial surge height data. Historical records of Philippine typhoons cover a relatively extensive period extending back to the Spanish colonial era (1521 to 1898), but detailed reports for a specific event are rare and perhaps biased towards high-impact events such as those with a high death toll. Notably, uncertainties due to different instrumentation between two periods of time cannot be avoided due to technological development through time but to some extent the uncertainties can be overcome (Chapter 2, Appendix 3). 
Apart from written records, typhoons and storm surges also leave a legacy of geomorphic and sedimentologic imprints on the coasts. The coastal response to a specific event can vary across sites due to variations in coastal setting and landscapes, and the varying overwash regimes. A segment of siliciclastic coast of Tanauan sustained lateral beach erosion from $10 \mathrm{~m}$ to $25 \mathrm{~m}$ from Typhoon Haiyan (Chapter 3). Surface elevations of the re-exhumed mangrove soil, and the top of the exposed roots of the coconut trees indicate vertical beach erosion of about 1 to $2 \mathrm{~m}$. The complete inundation overwash of Typhoon Haiyan also left a vast sheet of sand that is fining to silt on the most inland extent about 1.5 to 1.8 $\mathrm{km}$. Near the coast immediate post-storm recovery rebuilt the beach dune system with a combination of overwash, vertical and lateral accretion. In comparison, Typhoon Durian's storm surge, which was only a fraction of the size of that of 2013 Typhoon Haiyan had caused minimal lateral erosion on a volcaniclastic coast of Lagonoy Gulf (Chapter 5). However, wave runup caused breaching on weaker portions of the barrier spit resulting in the formation of washover fans and washover terraces. Two prominent breaching sites are about $50 \mathrm{~m}$ to $250 \mathrm{~m}$ wide accompanied by vertical erosion of $2 \mathrm{~m}$ and $1 \mathrm{~m}$, respectively. Despite the different storm surge magnitudes and overwash regimes, washover fans and terraces seem to be a common sediment landform on these clastic coastlines. On the contrary, no washover fans or terraces were found on the carbonate coast of Hernani, Samar (Chapter 4). Instead, Typhoon Haiyan left conspicuous coral reef boulders strewn on the reef flat, and carbonate sand sheet that draped the coastal plain. The contrast between overwash sediments from Haiyan in areas that experienced similar storm surge conditions like Tanauan and Basey underscore 
the effect of local geology and the type of sediments available for transport (Chapter 3).

Haiyan's overwash sediment units represent an extreme storm surge event, which is valuable in expanding dataset for storm deposits between clastic and nonclastic carbonate coastal settings. On the clastic coast, the overwash sediments exhibit sharp depositional contact, planar stratification, coarsening upward sequences, and overall but not systematic landward fining (Chapter 3). On the carbonate coast, the overwash sediment assemblages include distinct carbonate boulders now occupying the reef flat surface, and a sand sheet that blanketed the coconut groves and rice fields of the coastal plain reaching up to $\sim 300 \mathrm{~m}$ inland (Chapter 4). A separate inverse modeling of flow velocity from boulder dimensions on the reef flat and sediment thickness and grainsize distribution inland indicate that the bore-like storm surge travelled across the wide reef flat and inundated the coast at a sustainably high flow velocity exceeding $4 \mathrm{~ms}^{-1}$. The sediment-derived flow velocity estimates are remarkably consistent with flow velocity values previously reconstructed from video recordings, and forward wave modeling. But considering the bore-like surge characteristic of Haiyan, which is similar to tsunami flow, Haiyan's overwash sediments as a representative of Philippine modern storm deposits should then be used with caution for pre-historic storm reconstructions. This cautionary note is particularly important because most of the Philippine coastlines are exposed to both storms and tsunamis. 
The coastlines impacted by Typhoon Haiyan and Typhoon Durian exhibit high potential recovery to their pre-typhoon conditions by active berm rebuilding on the beach and re-colonization of beach vegetation (Chapter 3 and Chapter 5). Even mangrove stands albeit sustaining massive defoliation during Typhoon Haiyan seemed to recover quickly (Chapter 3), though recovery in other areas was much slower (Chapter 5). It is also apparent that the recovery may only persist for as long as no disturbance will occur or if succeeding events are not capable of inducing more coastal impact (e.g. Chapter 5).

\subsection{Limitations}

This dissertation focused only on the geomorphic and sedimentologic imprints of overwash onshore. The impacts of storm surges on the shoreface were not investigated, but changes in sedimentation patterns are expected following storms particularly on areas with shallow and gently sloping offshore bathymetry such as Leyte Gulf (e.g. Kumar and Sanders, 1976; Morton, 1988; Siringan and Anderson, 1994). The onshore depositional conditions naturally expose these geomorphic and sedimentologic imprints to active agents of erosion or reworking which can likely reduce the potential longevity of preservation of such geologic storm archives. For example, the rapid recolonization of vegetation on the coastal plains following Typhoon Haiyan commonly obscured internal stratification and the stratigraphic contact between the Haiyan overwash sediments and the preHaiyan soil unit (Chapter 3). In contrast, despite re-vegetation and flooding occurrence, the geomorphic imprints of Typhoon Durian remain intact and prominent to at least 7 years (Chapter 5). There seems to be a good indication that this volcaniclastic coast has high preservation potential for overwash 
records. Shore-normal GPR transects also reveal at least two buried erosional surfaces farther inland of the erosional surface of Typhoon Durian. Unfortunately, the nature of volcaniclastic sands prohibited traditional dating techniques applied to overwash sands. Instead we are limited to comparing our results to historical storms in the long history of the Philippines.

\subsection{Future studies}

Typhoon Haiyan revealed scientific weak points other than those covered in this dissertation. Several key ideas for further investigations are identified as follows:

(1) A vast pool of historically documented typhoons is available and was previously used to establish long-term trends in landfall frequency, intensity, and location (e.g. Garcia-Herrera et al., 2007; Ribera et al., 2008; Kubota and Chan, 2009). There might not be another historical document as detailed as that of the Ty 1897 (Chapter 2), but we could still glean knowledge from piecing together patchy but reliable historical accounts to bring clarity for other historical typhoons. One event of interest can be the November 1912 which was reported to have caused extensive damage in Tacloban and Capiz on the nearby island of Panay and was believed to have claimed 15,000 lives (http://chroniclingamerica.loc.gov/lccn/sn83045433/1912-11-30/ed-1/seq1.pdf).

(2) The Philippines has highly variable coastal configuration, landscapes, and exposure to storm surge which require local-based scenarios for hazard assessment (Chapters 2 to 5 ). Highly developed and densely populated coastal areas can be prioritized for storm surge modeling and historical- 
based scenario studies (e.g. Manila Bay, northwest Luzon including Ilocos coastlines).

(3) A more detailed storm surge model of Typhoon Durian in Lagonoy Gulf is needed to assess contributions from storm tide and wave set-up, and then compare with geomorphic-based estimates from Chapter 5.

(4) Rapid coastal erosion from a single extreme event like Typhoon Haiyan can be in the order of few tens of meters (Chapter 3). How does this single event, with a recurrence interval of most probably nearly over 100 years, compare to the magnitude of longer-term coastal change?

(5) Compared to Tanauan (Chapter 3) there seems to be a higher preservation potential of onshore storm deposits in Hernani (Chapter 4). The search for geological archives of storm deposits will thus be more likely to be fruitful if pursued around Hernani.

(6) The hydrodynamic and sediment information from Typhoon Haiyan studies (Chapters 3-4) should be maximized for improved sediment transport modeling to better understand the relationship of storm surge flow dynamics and sedimentation patterns including particle size, thickness, inland extent, sediment source and supply.

\section{References}

Garci'a-Herrera, R., P. Ribera, E. Herna' ndez, and L. Gimeno, 2007. Northwest Pacific typhoons documented by the Philippine Jesuits, 1566-1900, Journal of Geophysical Research 112, D06108, doi:10.1029/2006JD007370.

Ribera, P., García-Herrera, R., and Gimeno, L., 2008. Historical deadly typhoons in the Philippines. Weather 63(7), 194-199. 
Kubota, H., and Chan, J. C. L., 2009. Interdecadal variability of tropical cyclone landfall in the Philippines from 1902 to 2005. Geophysical Research Letters 36, L12802, doi:10.1029/2009GL038108.

Kumar, N., and Sanders, J.E., 1976. Characteristics of shoreface storm deposits: nodern and ancient examples. Journal of Sedimentary Petrology 46 (1), 145-162.

Morton, R.A. 1988. Nearshore responses to great storms. GSA Special Papers 229, 7-22. doi: 10.1130/SPE229-p7.

Siringan, F.P., and Anderson, J.B., 1994. Modern shoreface and inner-shelf storm deposits off the east Texas coast, Gulf of Mexico. Journal of Sedimentary Research 64B (2), 99-110.

Switzer, A.D., Yu F., Gouramanis C., Soria, J.L.A., \& Pham D.T., 2014. Integrating different records to assess coastal hazards at multicentury timescales. Journal of Coastal Research SI 70, 723-729. 


\section{APPENDIX 1}

Soria, J.L.A., Switzer, A.D., Villanoy, C.L., Fritz, H.M., Bilgera, P.H.T., Cabrera, O.C., Siringan, F.P., Yacat-Sta. Maria, Y., Ramos, R.D., Fernandez, I.Q., 2016. Repeat storm surge disasters of Typhoon Haiyan and its 1897 predecessor in the Philippines. Bulletin of the American Meteorological Society 97(1), 31-48. doi, 10.1175/BAMS-D-14-00245.1 


\title{
REPEAT STORM SURGE DISASTERS OF TYPHOON HAIYAN AND ITS I897 PREDECESSOR IN THE PHILIPPINES
}

\author{
by Jannel Lea A. Soria, Adam D. Switzer, Cesar l. Villanoy, Hermann M. Fritz, \\ Princess Hope T. Bilgera, Olivia C. Cabrera, Fernando P. Siringan, \\ Yvainne Yacat-Sta. Maria, Riovie D. Ramos, and lan Quino Fernandez
}

Typhoon Haiyan's storm surge was about twice the height of the 1897 event in San Pedro Bay, but the two storm surges had similar heights on the open Pacific coast.

$\mathrm{T}$ yphoon Haiyan affected more than 16 million people, killed 6,293 people, and destroyed more than 1.1 million dwellings in the central Philippines (NDRRMC 2014). Haiyan is the deadliest

AFFILIATIONS: SORIA, SWITZER, AND RAMOS-Earth Observatory of Singapore, and Asian School of the Environment, Nanyang Technological University, Singapore; Villanor, BILgera, CABRERA, Siringan, Maria, and Fernandez-Marine Science Institute, University of the Philippines, Diliman, Quezon City, Philippines; FRITZ-School of Civil and Environmental Engineering, Georgia Institute of Technology, Atlanta, Georgia CORRESPONDING AUTHOR: Adam D. Switzer, Earth Observatory of Singapore, Nanyang Technological University, 50 Nanyang Avenue, Singapore 639798, Singapore

E-mail: aswitzer@ntu.edu.sg

Earth Observatory of Singapore Contribution Number 95

The abstract for this article can be found in this issue, following the table of contents.

DOI:10.1175/BAMS-D-14-00245.1

A supplement to this article is available online (10.1175/BAMS-D-14-00245.2)

In final form 29 May 2015

()2016 American Meteorological Society typhoon recorded in the Philippines, superseding Tropical Storm Thelma, which struck Ormoc City on the western coast of Leyte Island, in November 1991 (Alojado and Padua 2010; Bacani 2013; Ribera et al. 2008). Globally, Typhoon Haiyan was the deadliest cyclonic event since Cyclone Nargis devastated Myanmar in 2008 (Fritz et al. 2009). The damage to infrastructure and agriculture cost about PHP \$40 billion or about USD $\$ 900$ million (NDRRMC 2014), while the total economic loss reached up to USD 13 billion (Caulderwood 2014). The damage and the death toll from Typhoon Haiyan were particularly high along the coasts surrounding San Pedro Bay on the northwestern margin of the Leyte Gulf primarily due to the storm surge generated by the typhoon. The shallow bathymetry of less than 10-m depth and funnel shape make the coasts of San Pedro Bay inherently susceptible to storm surge (Fig. 1, inset). Additional factors that contributed to local amplification of the storm surge in Leyte Gulf were the orientation of the typhoon track and associated seiches (Mori et al. 2014). Eyewitnesses described the Haiyan storm surge as dramatically worse than any coastal flooding events in recent years (Amadore 2013). Longer historical records, 
$120^{\circ}$

130

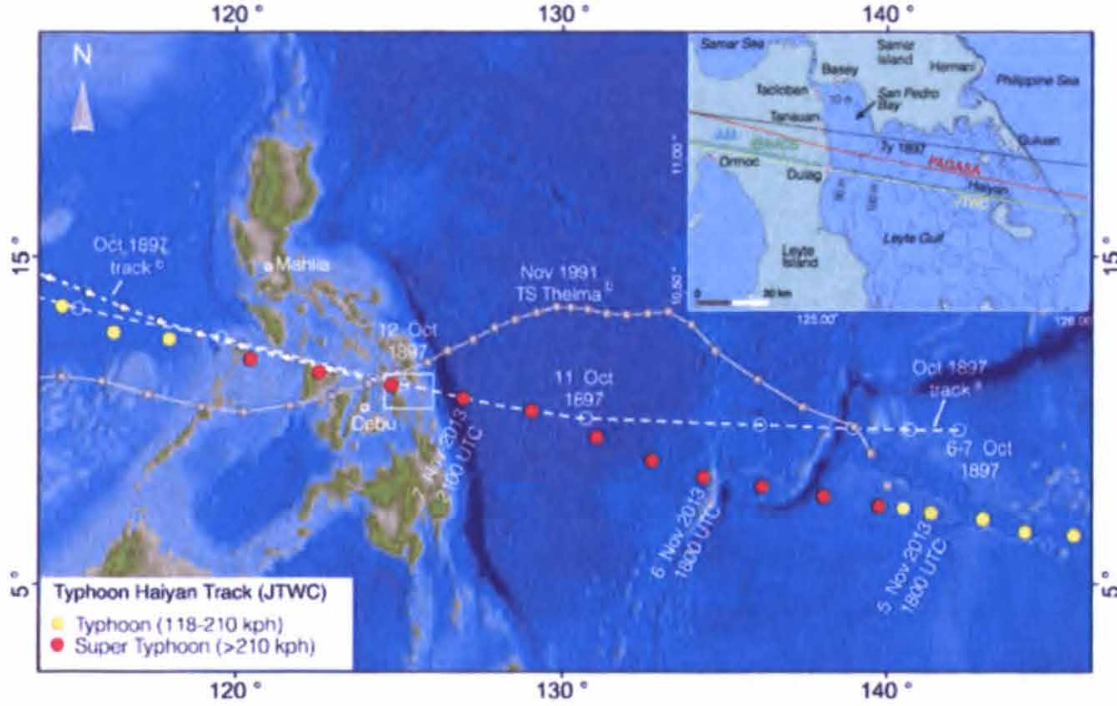

FIG. I. Storm tracks of three deadly typhoons crossing the central Philippines: Ty 1897, Nov 1991 Tropical Storm Thelma, and Nov 2013 Super Typhoon Haiyan. Typhoon track sources: (a) Algué (1898) and (b) International Best Track Archive for Climate Stewardship (IBTrACS) database of Knapp et al. (2010). The inset shows the comparative tracks of Ty 1897 (black dashed line) and Haiyan (colored solid lines) across Leyte Gulf.

however, reveal a comparable predecessor to Typhoon Haiyan (Algué 1898). In October 1897, an unnamed typhoon, which for brevity will be henceforth referred to as Ty 1897 , took a path across Leyte Gulf that was almost parallel to Typhoon Haiyan's but offset to the north by $\sim 6 \mathrm{~km}$ (Fig. 1). The similar track enables direct comparisons of the two typhoons and the storm surges. Here, we first characterize the destructiveness of Typhoon Haiyan before considering the importance of the 1897 predecessor in understanding storm surge hazard in the region.

TYPHOON HAIYAN. On 2 November 2013, a broad low pressure area formed in the western Pacific, to the east of Micronesia (Joint Typhoon Warning Center 2014). By 0600 UTC 3 November, it had developed into a tropical depression. At 0000 UTC 4 November, the system had attained tropical storm strength and was named Haiyan. It rapidly strengthened into a typhoon and moved west toward the Philippines (Fig. 1), and it was given the local name of Yolanda (NDRRMC 2013a). By 6 November, Haiyan's 1-min maximum sustained winds had intensified to an estimated $241 \mathrm{~km} \mathrm{~h}^{-1}$, classified by the Joint Typhoon Warning Center (JTWC) as a super typhoon. To avoid ambiguity in the definition of "super typhoon," we will conform to the traditional classification of tropical cyclones (World Meteorological Organization 2015) in the Pacific region with "typhoon." (NDRRMC 2013b).
On its final northwestward approach to the Philippines, Haiyan steadily intensified until it reached the peak intensity of $\sim 895 \mathrm{hPa}$ minimum central pressure. This peak intensity was estimated by the JTWC and the Japan Meteorological Agency (JMA) from cloud patterns recognized on visible and infrared satellite images, in the absence of ground and in situ instruments. In Guiuan municipality on Samar Island, Doppler radar data of the Philippine Atmospheric, Geophysical and Astronomical Services Administration (PAGASA) indicated that just before landfall, at 2000 UTC 7 November [0400 Philippine Time (PHT) 8 November], Haiyan attained a minimum central pressure of $910 \mathrm{hPa}$ and winds at $160 \mathrm{~km} \mathrm{~h}^{-1}$ with gusts of $\sim 195 \mathrm{~km} \mathrm{~h}^{-1}$ (Paciente 2014). Extreme winds destroyed the Guiuan Doppler radar station about 16 min later. At 2040 UTC 7 November (0440 PHT 8 November), Haiyan crossed the small islands off the southeast tip of Samar Island, near Guiuan. Haiyan then continued westward across the Leyte Gulf to its main landfall south of Tolosa, Leyte Island, at 2300 UTC 7 November (0700 PHT 8 November), as captured by another PAGASA Doppler radar station in Cebu. Typhoon Haiyan then made four subsequent landfalls as it crossed the central Philippines

MATERIAL AND METHODS. We evaluated eyewitness accounts, video recordings, field measurements, and storm surge model hydrographs to document the flow depths, surge heights, timing, and peak flood duration during Typhoon Haiyan as well as the resulting damage. Other post-Haiyan field survey reports focused on the inundation characteristics and the impact on coastal structures (Mas et al. 2015; Tajima et al. 2014). Here, we place Typhoon Haiyan's storm surge into historical context by comparing it with the similar Ty 1897 event (Algué 1898).

Field survey. The initial field survey of the coastal areas surrounding San Pedro Bay was conducted from 23 
to 28 November 2013, as soon as relief operations and the security situation permitted access to the hardest hit areas. We recorded 73 eyewitness accounts (Table ES1; more information can be found online at http://dx.doi.org//0.II75/BAMS-D-14-00245.2) on the maximum flow depth, the timing of the initial rise, and peak and subsidence of the flood, along with wind and wave observations. Collected data were used to validate the timing and heights simulated by our storm surge models. Subsequent surveys from 16 to 25 January, 12 to 19 May, and 2 to 10 June 2014 encompassed larger and more remote areas, including coastal settlements in southern Samar facing the Leyte Gulf and the Philippine Sea of the western Pacific (Fig. 2; Table 1). To record distances and build cross-shore elevation profiles from the water surface at the shoreline to the inundation limit, water marks were located and measured with a Trimble global positioning system (GPS) rover connected via Bluetooth to a Lasercraft XLRic laser range finder (Fritz et al. 2012). At each site, high water marks such as mud lines on buildings, scars on the bark of trees, and rafted debris were evaluated using established protocols (Fritz et al. 2007; UNESCO 2014). In inhabited areas, the water marks were discussed with eyewitnesses to constrain still water levels, estimate the contribution of storm waves, and remove bias from localized splashup atop the surge. The high water measurements, based on different indicators at corresponding locations, tended to be consistent and have an individual

Figure 2. above sea level. confidence of $\pm 0.1 \mathrm{~m}$. During post-survey processing, the measurements were differentially corrected with our daily setup of the local Ashtech base station and corrected for tide level at the time of peak storm surge on the basis of tide predictions provided by XTide 2, an open-source software of Flater (1998). How the Ty 1897 storm surge heights were measured remains unknown, but it is highly likely that surge heights

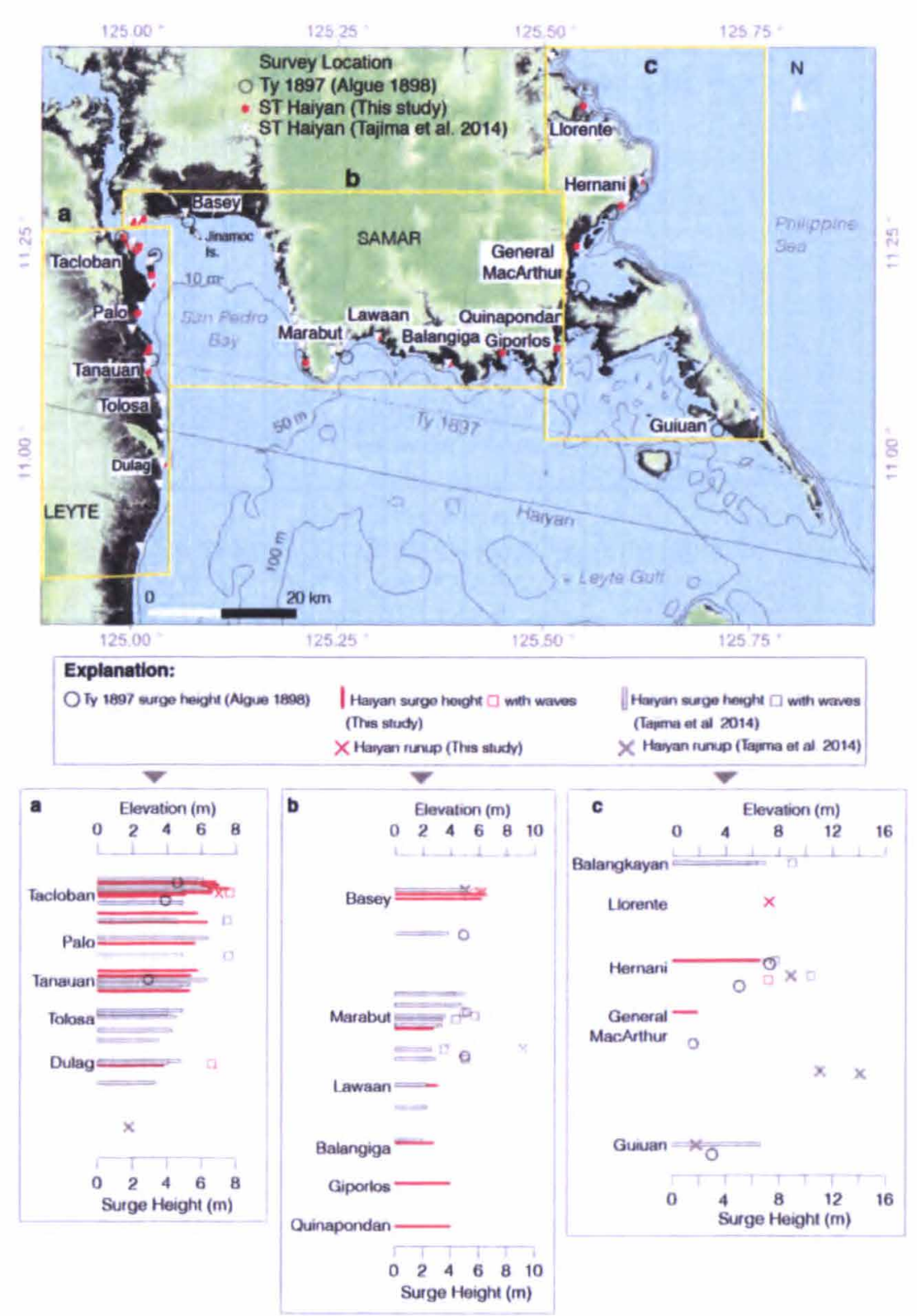

Fıg. 2. Maximum storm surge heights, surge with waves, and runup points of Typhoon Haiyan measured in the field across the coastal communities in eastern Leyte (a), and Samar (b) and (c). Surge heights of Ty 1897 from Algue (1898) are also included for comparison. The terrain map is a modified NASA land elevation radar image; dark shaded areas are $\leq 10 \mathrm{~m}$, 


\begin{tabular}{|c|c|c|c|c|c|c|c|c|c|c|c|c|c|c|c|c|c|c|c|c|c|c|c|c|c|c|}
\hline 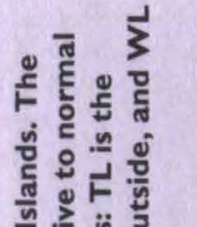 & 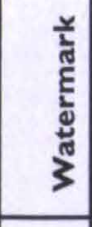 & $\begin{array}{l}n \\
\xi \\
\xi \\
\xi\end{array}$ & $\begin{array}{l}3 \\
3 \\
4\end{array}$ & ב & 㣽 & 㤐 & 诺 & ن & $\frac{I}{\omega}$ & $\begin{array}{l}3 \\
u \\
\dot{H} \\
\dot{F}\end{array}$ & $\begin{array}{l}3 \\
3 \\
\dot{m} \\
1 \\
\end{array}$ & \begin{tabular}{|l|}
3 \\
3 \\
0 \\
\\
\end{tabular} & \begin{tabular}{|l|}
3 \\
$w$ \\
$\bar{\Sigma}$
\end{tabular} & \begin{tabular}{|c|} 
\\
$w$ \\
\\
\end{tabular} & 学 & & \begin{tabular}{l|l}
3 & 3 \\
$w$ & $\underline{u}$ \\
$\dot{\Sigma}$ & $\bar{\Sigma}$ \\
\end{tabular} & 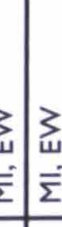 & $\begin{array}{l}3 \\
\dot{\Sigma} \\
\dot{\Sigma}\end{array}$ & \begin{tabular}{|l}
$\tilde{3}$ \\
$\vdots$ \\
0 \\
\end{tabular} & $\mid \begin{array}{l}3 \\
3 \\
4 \\
3 \\
3\end{array}$ & $\vec{F}$ & 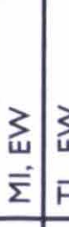 & & 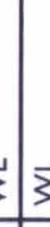 & 3 \\
\hline 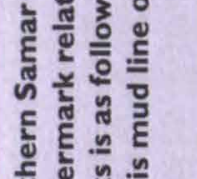 & 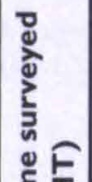 & $\tilde{\Xi}$ & 苂 & $\underline{\underline{n}}$ & $\overline{\underline{S}}$ & 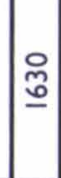 & 志 & 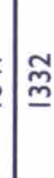 & 을 & ్ㅡㅇ & $\stackrel{\Xi}{\Xi}$ & $\stackrel{\substack{m \\
=}}{=}$ & $\stackrel{\tilde{m}}{\beth}$ & $\overline{\bar{\Xi}}$ & 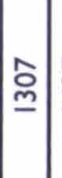 & $\widehat{\Im}$ & 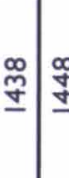 & $\begin{array}{l}0 \\
q \\
\end{array}$ & $\underline{\underline{\underline{n}}}$ & 芷 & 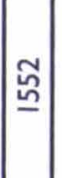 & 읭 & $\underline{\overline{0}}$ & & . & : \\
\hline 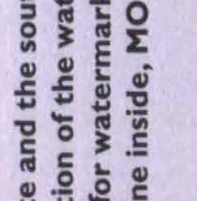 & 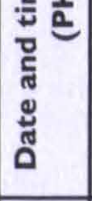 & 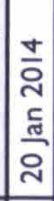 & $\begin{array}{l}\frac{9}{4} \\
\frac{9}{4} \\
\frac{9}{4} \\
5\end{array}$ & 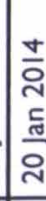 & $\frac{\sqrt{0}}{\frac{9}{4}}$ & 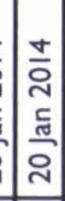 & $\frac{9}{3}$ & $\begin{array}{l}\frac{\pi}{4} \\
\frac{\pi}{4} \\
\frac{\pi}{4}\end{array}$ & $\begin{array}{l}\frac{4}{3} \\
\frac{1}{4} \\
4\end{array}$ & 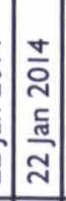 & 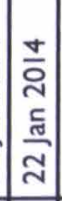 & 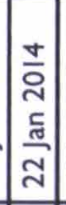 & 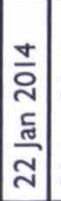 & 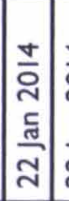 & 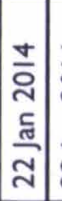 & 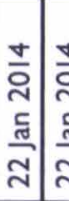 & 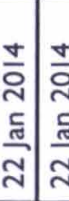 & 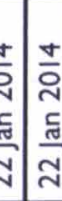 & 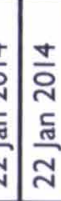 & 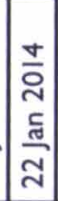 & 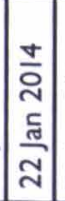 & 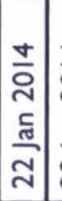 & 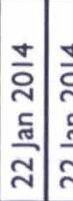 & 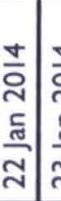 & $\frac{a^{2}}{2}$ & ר. \\
\hline 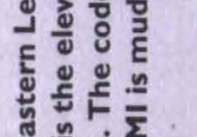 & $\underset{\alpha}{\widehat{E}}$ & & & & & & & & & & & & & & & & & & & & ס & & & & 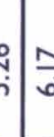 & $\mid \begin{array}{l}0 \\
0 \\
0\end{array}$ \\
\hline 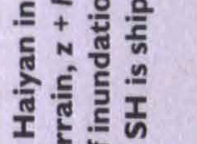 & $\begin{array}{c}\widehat{E} \\
5 \\
+ \\
\mathrm{N}\end{array}$ & 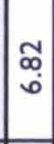 & $\underset{n}{\infty}$ & 离 & fi & 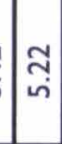 & $\underset{\text { ஸn }}{\tilde{m}}$ & hึ & ְ. & 苗 & 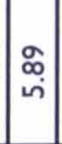 & 容 & 잇 & $\begin{array}{l}\hat{n} \\
+ \\
+\end{array}$ & $\mid$ & $\underset{j}{2}$ & 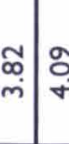 & 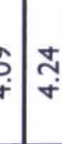 & ن. & 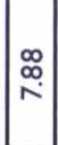 & & ల్ల్ర & గું & & & \\
\hline 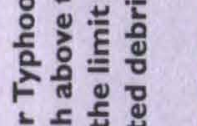 & \begin{tabular}{l}
$\hat{\xi}$ \\
\multicolumn{1}{c}{}
\end{tabular} & $\begin{array}{l}\stackrel{0}{0} \\
\dot{+}\end{array}$ & $\stackrel{-}{-}$ & $\stackrel{R}{R}$ & ন্ & $\underset{m}{\circ}$ & 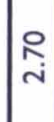 & $\stackrel{R}{\sim}$ & 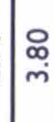 & ?ִ & $\begin{array}{l}0 \\
\stackrel{\infty}{\infty} \\
\sim\end{array}$ & 우 & ¿্ & 㔛 & $\begin{array}{c}R \\
m \\
m\end{array}$ & : & $\stackrel{0}{-1}$ & : & 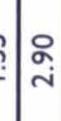 & 웅. & & $\frac{0}{i}$ & 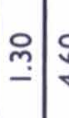 & $\begin{array}{l}\text { D. } \\
+ \\
+\end{array}$ & & \\
\hline 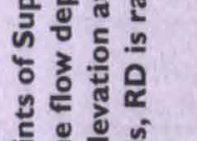 & ह్ & $\underset{\sim}{\tilde{N}}$ & 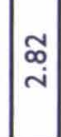 & 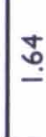 & กู & $\underset{\sim}{\pi}$ & ָָ & 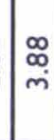 & 号 & $\mid \begin{array}{l} \pm \\
\infty \\
\text { ஸे }\end{array}$ & $\left|\begin{array}{l}0 \\
0 \\
\text { ja }\end{array}\right|$ & $\mid \begin{array}{l}0 \\
\dot{+} \\
\end{array}$ & $\frac{0}{+}$ & ì & 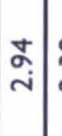 & $\underset{\sim}{\stackrel{\sim}{\mathbf{j}}}$ & $\underset{d}{\sigma}$ & ì & $\dot{i}$ & $\underset{\substack{\infty \\
\sim}}{\stackrel{\infty}{*}}$ & 뭇 & $\underset{\leftarrow}{\tau}$ & $\underset{\leftarrow}{\widetilde{\tau}}$ & ¿ִ & $\stackrel{0}{0}$ & : \\
\hline 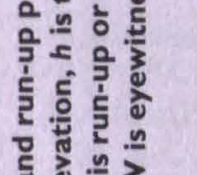 & 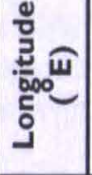 & 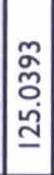 & 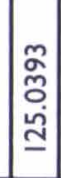 & 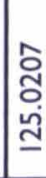 & 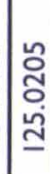 & 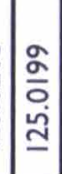 & 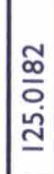 & 章 & 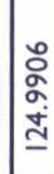 & $\mid \begin{array}{l}n \\
\vdots \\
\alpha \\
\dot{1} \\
\text { ปn }\end{array}$ & 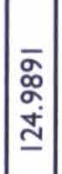 & 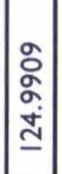 & 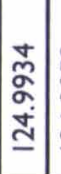 & {$\left[\begin{array}{l}\tilde{\alpha} \\
\alpha \\
\dot{\Xi} \\
\vdots\end{array}\right.$} & 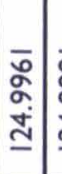 & 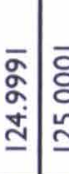 & 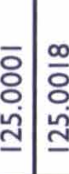 & 它 & 突 & 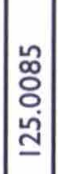 & 离 & 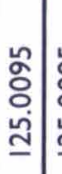 & & 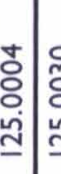 & 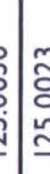 & \\
\hline 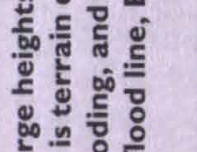 & 胥记 & \begin{tabular}{|c|}
0 \\
0 \\
$o$ \\
$o$ \\
0 \\
0
\end{tabular} & $\mid \begin{array}{l}\infty \\
0 \\
0 \\
0 \\
0 \\
0\end{array}$ & ờ & $\stackrel{=}{\underline{N}}$ & 望 & $\stackrel{\varrho}{\underline{E}}$ & 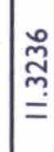 & 趈 & 釉 & 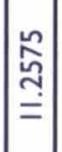 & $\mid \begin{array}{c}\underset{n}{\sim} \\
\stackrel{2}{=} \\
\stackrel{=}{=}\end{array}$ & 志 & 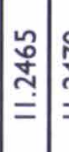 & 足 & 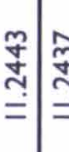 & 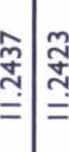 & = & & 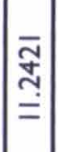 & $\mid$ & 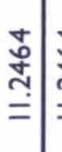 & 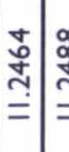 & 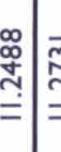 & 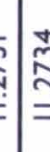 & ז̊ \\
\hline 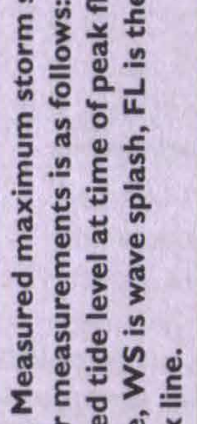 & 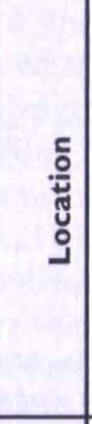 & 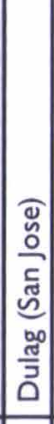 & 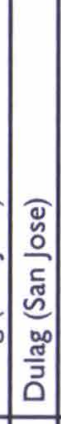 & 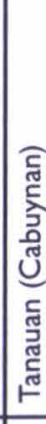 & 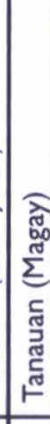 & 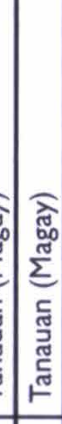 & 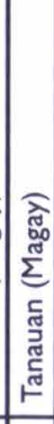 & 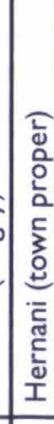 & 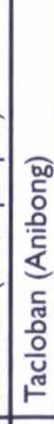 & 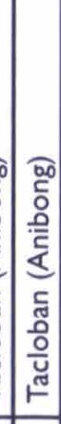 & 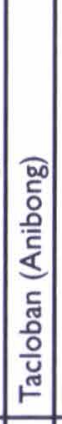 & 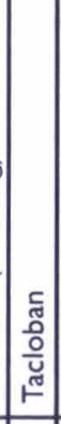 & 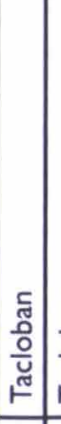 & 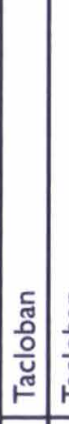 & 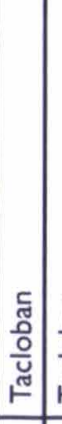 & 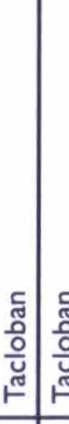 & 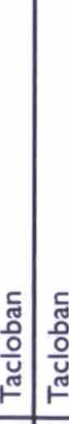 & 吾 & 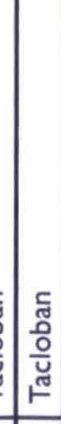 & 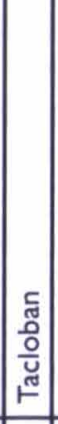 & 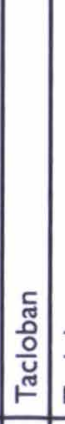 & 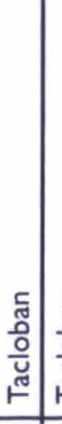 & 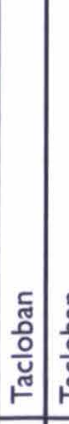 & : & 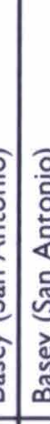 & \\
\hline 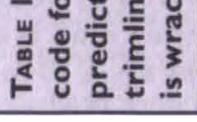 & $\frac{\mathrm{t}}{0}$ & & $\sim$ & m & + & in & 0 & 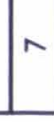 & $\infty$ & 10 & 으 & $=$ & $\simeq$ & $\underline{m}=$ & $\Xi$ & 느 & $\simeq 1$ & $=\underline{\infty}$ & 0 & 요 & $\bar{N}$ & הี & $\tilde{\tau}$ & \pm & & \\
\hline
\end{tabular}




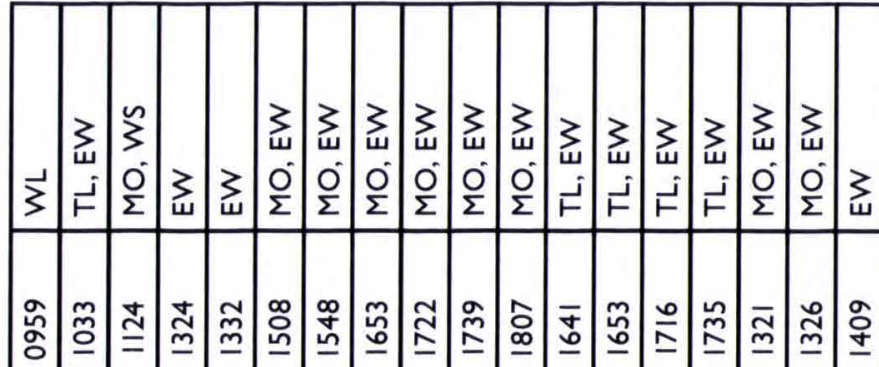

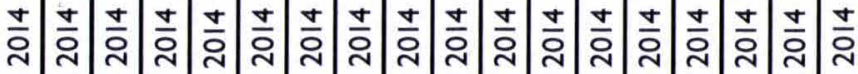

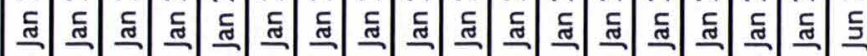

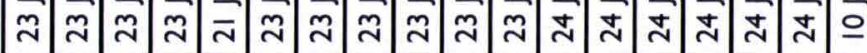

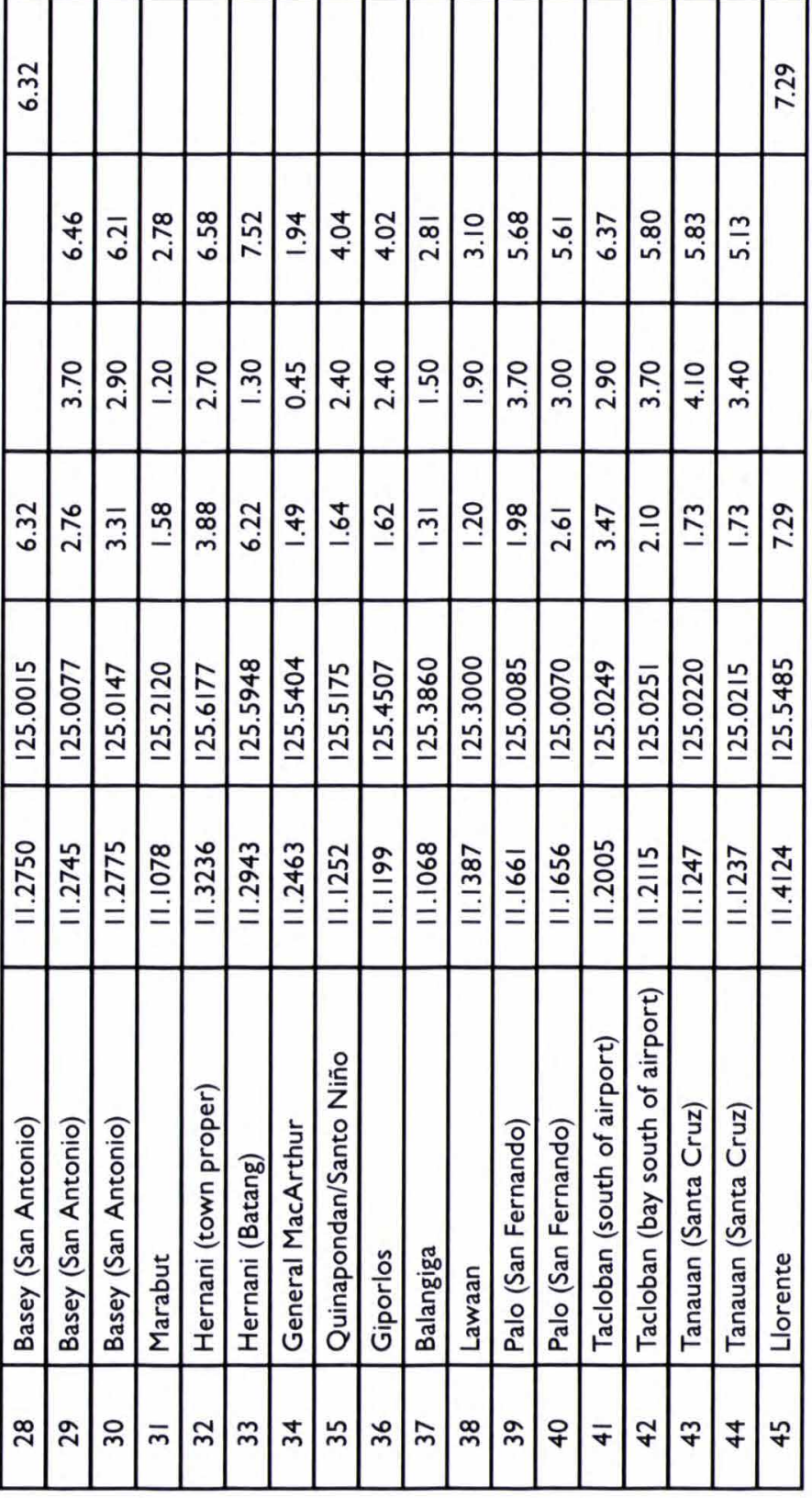

were simply referenced to the mean sea level at the time of survey. The difference between the mean sea level and the sea level at the time of peak flood during Ty 1897 implies that the accuracy of surge height measurements is in the range of $\pm 0.3 \mathrm{~m}$. Algué (1898) lacks description on the surge height indicators, but additional uncertainties can be potentially contributed by storm waves.

Storm surge modeling of Typhoon Haiyan. The Typhoon Haiyan storm surge in Leyte Gulf and San Pedro Bay was simulated using the open-source Delft3D Flow (Lesser et al. 2004) with a MATLAB-based graphical user interface called Dashboard. ${ }^{1}$ A curvilinear grid is used with a minimum resolution of $200 \mathrm{~m}$ and a maximum resolution of $1.2 \mathrm{~km}$. The domain encompasses the whole Leyte Gulf and extends into the San Juanico Strait to the north (Fig. 3a). The bathymetry of the model domain was acquired from digitized navigational charts (National Mapping and Resource Information Authority 1980). The maximum depths are found near the Leyte Gulf mouth, and the embayment shallows northward toward the San Juanico Strait (Fig. 3b). Open boundary conditions are astronomic tides using eight dominant constituents $\left(\mathrm{M}_{2}, \mathrm{~S}_{2}\right.$, $\mathrm{N}_{2}, \mathrm{~K}_{2}, \mathrm{~K}_{1}, \mathrm{O}_{1}, \mathrm{P}_{1}$, and $\mathrm{Q}_{1}$ ) extracted and interpolated from the Ocean Topography Experiment (TOPEX7.2) global tidal model (Egbert and Erofeeva 2002) using the Dashboard tide database toolbox. The tidal pattern in San Juanico Strait interacting with the Samar Sea differs from the tidal pattern at Guiuan station driven by the Philippine Sea (Fig. 3c). The complex tidal interaction highlights the need for accurate bathymetry of Leyte Gulf and San Juanico Strait to properly simulate the tides in Tacloban.

Typhoon wind fields for the modeling were generated from the typhoon track data of the JTWC. We recognize an approximately $6-\mathrm{km}$ offset between the JTWC typhoon track from the Doppler radar-derived track from PAGASA (Fig. 1, inset), but JTWC provides more continuous along-track wind data, required in the model. The model wind

'http://publicwiki.deltares.nl/display/OET /DelftDashboard 
files were generated by the Delft Dashboard tropical cyclone toolbox using the model by Holland (1980) and interpolated onto the computational grid. The model was initialized by wind and tide conditions at 0000 UTC 5 November 2013 and allowed to run until 2400 UTC 11 November 2013. Sea level and current outputs were saved at 1-min intervals between 1900 UTC 7 November and 0600 UTC 8 November. An earlier model of Bricker et al. (2014) used the same Delft3D software with JMA wind data forcing and a Quiring's relationship of maximum wind radius. Their model yielded a maximum water level of less than $6 \mathrm{~m}$ in Tacloban.

Storm surge modeling of Ty 1897. To model the likely storm surge generated by Ty 1897 , we used the same grid and boundary forcing conditions of Typhoon Haiyan, but with tides simulated from 10 to 12 October 1897. Algué (1898) reported pressures and winds recorded in various parts of the Philippines during Ty 1897, but the Dashboard typhoon module requires along-track minimum central pressures and maximum winds. This requirement limited us to use only the data recorded in areas directly hit by the eye of Ty 1897: the in situ barometric pressures measured at Guiuan and Tanauan. Apart from these two locations, no instrumental record on the typhoon eye exists. The minimum pressures before landfall in Guiuan and after landfall in Tanauan were estimated considering the values for Ty 1897 and Typhoon Haiyan. Barometric records in Guiuan and Tanauan indicate a less intense Ty 1897 at landfall than Typhoon Haiyan. To account for the weaker intensity of Ty 1897 , we took the pressure difference between Typhoon Haiyan and Ty 1897 in Guiuan and in Tanauan, and the delta values were then subtracted from the Typhoon Haiyan pressure values.

Given the barometric records of Ty 1897 in Guiuan and Tanauan, a range of wind speed values were derived from empirical wind-pressure relationships using the storm-mapping table summarized by Nakazawa and Hoshino (2009) for the western North Pacific region (Table 2). Due to the limited instrumental data on Ty
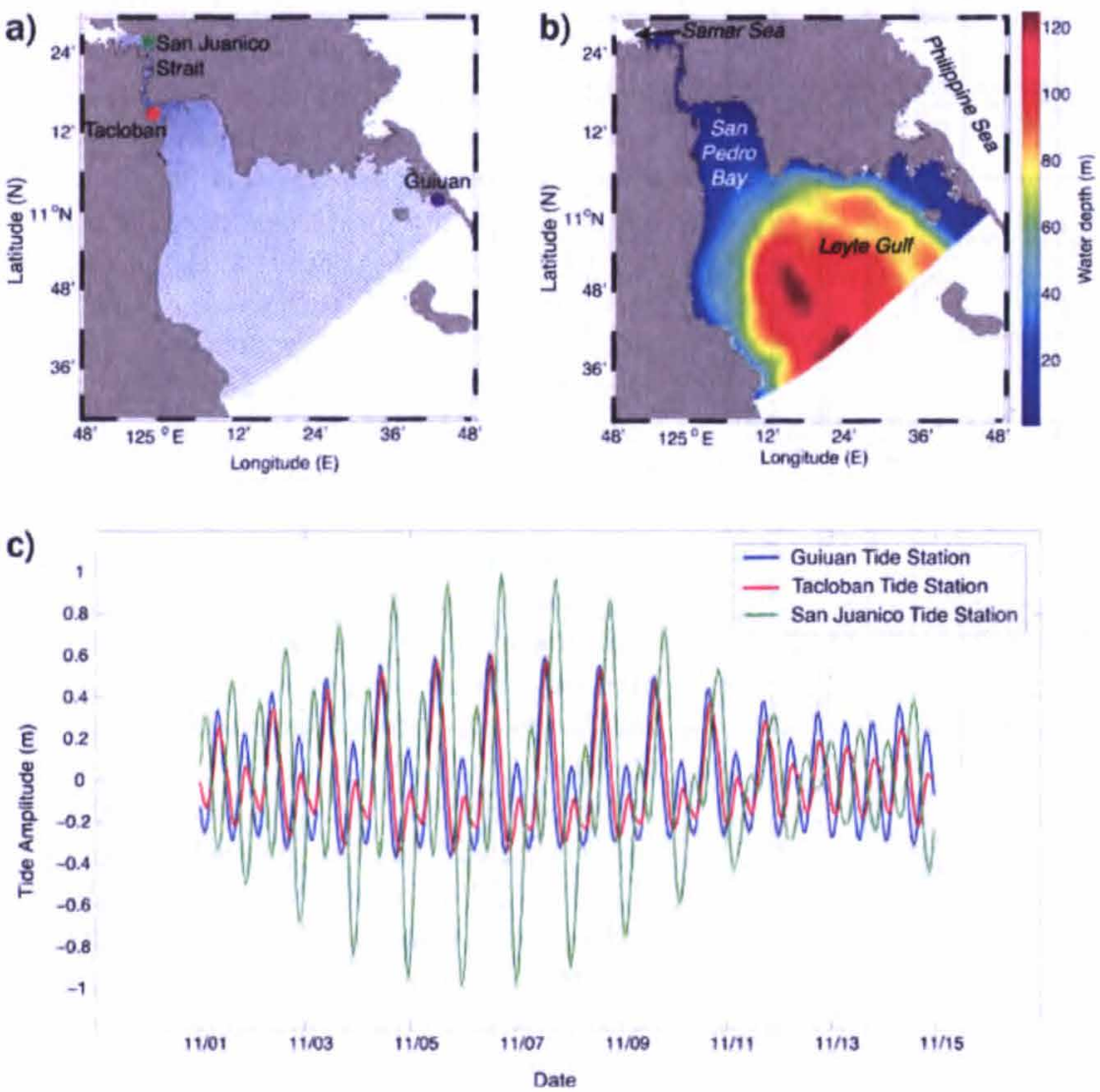

Fig. 3. Geographical coverage, bathymetry, and tidal conditions of Leyte Gulf used in the model. (a) The model domain is a curvilinear grid with $200-\mathrm{m}$ to $1.2-\mathrm{km}$ resolution. (b) Leyte Gulf bathymetry generated from digitized navigational charts with $100-\mathrm{m}$ to $\mathrm{I}-\mathrm{km}$ resolution. (c) Predicted water levels from San Juanico Strait, Tacloban City, and Guiuan, Samar.
1897 we opted to use in our model the wind speed values derived from Atkinson and Holliday (1977), which is the most direct method among the wind-pressure relationship equations. Knaff and Zehr (2007) emphasized the uncertainties inherent in the regression method of Atkinson and Holliday (1977) in estimating wind speeds of tropical cyclones over the northwest Pacific. Despite the reliability concerns, the maximum wind speed estimates for Ty 1897 using Atkinson and Holliday (1977) still yielded values similar or within the range of the mean standard error [6-9 kt $\left.\left(1 \mathrm{kt}=0.5144 \mathrm{~m} \mathrm{~s}^{-1}\right)\right]$ of other established robust windpressure relationships.

TYPHOON I 897
VERSUS TYPHOON
HAIYAN. Typhoon track
and forward speed. The
reconstructed track of
Ty 1897 (Figs. 1, 2) was


TABLE 2. Minimum barometric pressure of Ty 1897 recorded in Guiuan and Tanuan and the corresponding $\mathrm{Cl}$ number and maximum wind speeds.

\begin{tabular}{|c|c|c|c|}
\hline Parameters/location & Guiuan & Tanauan (initial) & Tanauan (corrected) \\
\hline Time and date & $\begin{array}{l}0815 \mathrm{PHT} \\
12 \text { Oct } 1897\end{array}$ & $\begin{array}{l}1110 \mathrm{PHT} \\
12 \mathrm{Oct} 1897\end{array}$ & $\begin{array}{l}1110 \mathrm{PHT} \\
12 \text { Oct } 1897\end{array}$ \\
\hline Minimum central pressure $(\mathrm{mm})$ & 710 & 704 & 694 \\
\hline Minimum central pressure $(\mathrm{hPa})$ & 947 & 938 & 925 \\
\hline Observed wind condition & Relative calm ${ }^{\mathrm{a}}$ & Absolute calm & Absolute calm \\
\hline $\begin{array}{l}\left.\text { I-min maximum sustained winds [ } \mathrm{kt}\left(\mathrm{km} \mathrm{h}^{-1}\right)\right] \text { (Atkinson and } \\
\text { Holliday 1977) }\end{array}$ & $96(179)$ & $105(194)$ & $115(212)$ \\
\hline $\mathrm{Cl}$ (Dvorak 1975) & 6 & 6.5 & 7 \\
\hline $\mathrm{Cl}$ (Dvorak 1984) & 5.5 & 6 & 6 \\
\hline I-min maximum sustained winds [kt $\left.\left(\mathrm{km} \mathrm{h}^{-1}\right)\right]$ (Dvorak 1984) & $102(189)$ & $115(213)$ & $115(213)$ \\
\hline $\mathrm{Cl}$ (Koba et al. 1990) & 5.5 & 6 & 6.5 \\
\hline 10-min maximum sustained winds [ $\left.\mathrm{kt}\left(\mathrm{km} \mathrm{h}^{-1}\right)\right]$ (Koba 1990) & $85(157)$ & $93(172)$ & $100(185)$ \\
\hline
\end{tabular}

The relatively calm wind condition recorded in Guiuan indicates that the eye passed close but not directly over the recording site. As such the Guiuan dataset should be considered a near-minimum value.

adopted from Algué (1898) based on the synthesis report containing maps and compilation of barometric curves. Instrumental records for the historical Ty 1897 came from modified aneroid barometers established by Jesuit priests on land (at churches) and at sea (on ships) in different locations of the Philippine Archipelago. The observed pressure, wind direction, and temperature were used to establish the distance and direction of the vortex (eye) of the typhoon from the observer (Algué 1904; Udías 1996). Algué's map was georeferenced to a regional map derived from a $90 \mathrm{~m} \times 90 \mathrm{~m}$ resolution satellite radar image, and then the typhoon track was digitized. Given the different resolutions between Algué's map and the regional map, we expect that the digitized track has uncertainties of $\sim 1 \mathrm{~km}$ in the north-south direction and $\sim 2 \mathrm{~km}$ in the east-west direction.

Upon evaluating the pressure and wind observations, Algué (1898) estimated the landfall timing and the forward speed of Ty 1897 between Guiuan and Tanauan. Ty 1897 made its initial landfall $\sim 10 \mathrm{~km}$ south of Guiuan shortly after 0800 PHT 12 October 1897 (0000 UTC 12 October). At landfall, the barometer in Guiuan registered the lowest pressure at $710 \mathrm{~mm}(947 \mathrm{hPa})$, simultaneous with the observed relatively calm winds. The relatively calm wind condition indicates an eye passage in close proximity but not directly over the recording site. As such, the Guiuan dataset should be considered only as a nearminimum value. The typhoon continued westward almost following along the northern coastline of Leyte Gulf. At about 1100 PHT 12 October 1897 (0300 UTC 12 October) the eye of the typhoon was about $21 \mathrm{~km}$ north-northeast (NNE) of Dulag, and $13 \mathrm{~km}$ southsoutheast (SSE) of Tacloban, before it made a second landfall in Tanuan shortly after 1100 PHT. At landfall, the barometer in Tanauan registered the lowest pressure of $704 \mathrm{~mm}$ equivalent to $938 \mathrm{hPa}$, but after further analysis was lowered to $694 \mathrm{~mm}$ equivalent to $925 \mathrm{hPa}$ (Algué 1898, 1904). Simultaneous with the lowest pressure was an absolute calm wind lasting for about $40 \mathrm{~min}$. To the north, the adjacent town of Palo also experienced the zone of absolute calm but only for $10 \mathrm{~min}$. The longer duration of absolute calm in Tanauan compared to Palo suggests that Tanauan was located closer to the center of the typhoon's eye. In a span of $2.5 \mathrm{~h}$, Ty 1897 traversed about 43 geographical miles $(\sim 80 \mathrm{~km})$ between Guiuan and Tanuan, equivalent to a forward speed of about $17 \mathrm{mi} \mathrm{h}^{-1}$ or $28 \mathrm{~km} \mathrm{~h}^{-1}$ (Algué 1898, p. 66). According to Algué's map, Ty 1897 made subsequent landfalls on three islands across the central Philippines before it exited into the South China Sea.

The Jesuits ground-based method of instrumental recording and monitoring of typhoons to establish the track and intensity prevailed for many decades (Udías 1996) until it was replaced by reconnaissance aircraft, radar, and satellite observations toward the midtwentieth century (Emanuel 2005b; Velden et al. 2006). Today, weather services combine instrumental recordings with satellite-based observations of the cloud patterns in visible and infrared satellite images to establish a central location of a typhoon and to estimate typhoon intensities. At the forefront of this satellite-based method of tropical cyclone intensity was Dvorak (1975). The Dvorak method originally 
developed for Atlantic conditions has been adopted and applied to other ocean basins that have different atmospheric conditions like the Pacific (e.g., Velden et al. 2006; Knaff and Zehr 2007; Lander et al. 2014). Unfortunately, there is no unified operational method among weather agencies for tracking and assigning typhoon intensities, and as such, the reported track and intensity of one storm are commonly variable. This was the case with Typhoon Haiyan, where the tracks across Leyte Gulf released by JMA and JTWC are consistently offset $\sim 6 \mathrm{~km}$ to the south of the PAGASA Doppler radar-based track. The PAGASA track, however, appears more consistent with the local field observation and ground truthing (Morgerman 2014). We note that based on the PAGASA typhoon track, Typhoon Haiyan moved from Guiuan westward to Tolosa at about $43 \mathrm{~km} \mathrm{~h}^{-1}$ or about 1.5 times faster than Ty 1897.

Typhoon intensity and size. The wide range of instrumental recording through history and the variety of operational wind-pressure relationships among meteorological agencies make typhoon intensity classification based on the maximum wind speed inherently uncertain (Knaff and Zehr 2007; Nakazawa and Hoshino 2009). To address the issues arising from the wind speed-derived typhoon intensity, Knapp and Kruk (2010) and Kruk et al. (2011) proposed the use of current intensity (CI) in comparing typhoons, particularly in establishing trends of tropical typhoon intensities. Kruk et al. (2011) recognized that because of the imagery interpretation of contemporary typhoons, the satellite-derived intensity $T$ number when converted to $\mathrm{CI}$ could result in intensity differences of 0.5 on the $\mathrm{CI}$ scale. Meanwhile, the primary sources of uncertainty for the pressure-derived intensity of historical typhoons such as Ty 1897 arise from the sparse recordings and possible instrumental errors. The historic correction of $\sim 13 \mathrm{hPa}$ applied to the minimum pressure of Ty 1897 on the Tanauan barometer record may give some indication of the magnitude of instrumental errors. For intense typhoons like Ty 1897 , the historic correction corresponds to a difference of 0.5 on the CI scale, which is of similar magnitude as the uncertainty of satellite-derived CI. Hence, the corresponding CI numbers for Ty 1897 and Typhoon Haiyan may provide a reasonable metric to compare the intensity between these two typhoons.

As discussed previously, the observed lowest pressure and absolute calm wind of Ty 1897 consistently indicate that the typhoon eye passed directly over Tanauan. Taking the minimum pressure of $925 \mathrm{hPa}$ as the closest approximation of the central minimum pressure, Ty 1897 was assigned an equivalent CI number of 6-7 upon landfall. For Typhoon Haiyan, ground instruments only recorded nearminimum pressures. The Doppler radar in Guiuan registered a mean sea level pressure of $\sim 940 \mathrm{hPa}$ before it was totally destroyed at the peak intensity of the typhoon (IRIDeS 2014). Independent measurements of PAGASA and Morgerman (2014) indicate lowest pressure at $960 \mathrm{hPa}$ in Tacloban City, which was located on the northern eyewall of the typhoon, $24 \mathrm{~km}$ away from Typhoon Haiyan's center. In contrast, using the satellite-based Dvorak technique Typhoon Haiyan has a signature typhoon number of T8.0 (Lander et al. 2014), which corresponds to a CI number of 8 , the highest on the scale. As such, the CI 8 Typhoon Haiyan was more intense than the CI 6 to 7 of Ty 1897.

Not only was Typhoon Haiyan more intense, it was also larger than Ty 1897 based on the eyewall size. Morgerman (2014) corroborated the eye of Typhoon Haiyan based on wind observations of eyewitnesses and a radar image, indicating a $13-\mathrm{km}$ radius of the eyewall. In contrast, the Jesuit approach based on the zones of absolute and relative calm winds as indicators of the relative location of the typhoon eye results in an eyewall radius of 6-10 km for Ty 1897.

Given the contrasting operational methods between 1897 and 2013, it remains difficult to directly compare Typhoon Haiyan and Ty 1897 with absolute certainty. The available meteorological parameters, however, suggest that Typhoon Haiyan and Ty 1897 were nearly identical based on the trajectory, while characteristic differences prevailed concerning other aspects. Typhoon Haiyan followed a parallel track direction with a $\sim 6-\mathrm{km}$ offset to the south of Ty 1897 . Typhoon Haiyan was more intense, had wider eyewall coverage, and was moving faster than Ty 1897 . The possible effects of the slight variations in track, minimum central pressure, estimated maximum winds, and forward movement between the two typhoons on the storm surge characteristics will be explored in the following sections.

\section{TYPHOON 1897 AND TYPHOON HAIYAN} STORM SURGES. Posttyphoon field measurements. The Ty 1897 storm surge measurements of Algué (1898) were based on eyewitness accounts (Fig. 2). These field measurements indicate inundation heights exceeding $4 \mathrm{~m}$ in most places with a maximum height of over $7 \mathrm{~m}$ on the open sea coast at Hernani (Fig. 2c). Along San Pedro Bay in Basey (Fig. 2b), the water gradually rose and reached a maximum level 
of $4.9 \mathrm{~m}$. The peak flooding corresponded with the most violent winds from the southeast. In the nearby coast of Tacloban (Fig. 2a), water rose between 3.9 and $4.6 \mathrm{~m}$. The peak flooding coincided with the winds blowing from the east to east-southeast, directly perpendicular to the Tacloban coast. In close proximity to the eye of Ty 1897 at Tanauan and Tolosa (Fig. 2a), the water rose to $3 \mathrm{~m}$.

Algué's "Ola del Huracán" or hurricane wave was the elevation of the sea, with the surface forming like a warp pyramid whose peak approximately corresponds to the vortex (eye) of the typhoon, analogous to the water surface being sucked by a vacuum pump (Algué 1898, p. 9). Moving with the typhoon, this huge wave, when launched against the shore, makes the water rise to an extraordinary height, causing severe flooding and extensive destruction (Algué 1898, p. 10). We interpret this description as equivalent to what we now call "storm surge." Algué overestimated the contribution of the pressure drop over the wind field as the primary contributor to the significant rise of the sea surface because of the different locations of the eye and the areas where water elevations were highest. The sea rose to about $3 \mathrm{~m}$ in Guiuan and Tanauan, but the rise was highest at Hernani, Basey, and Tacloban on the typhoon's strong side to the north of the typhoon eye. The peak flooding during Ty 1897 at each of these sites consistently coincided with winds blowing directly perpendicular toward the coastline. Contrary to Algué's attribution of the surge solely to the low central pressure, the wind field was the primary driver of the storm surge (Emanuel 2005a).

The measured high water marks after Typhoon Haiyan (Fig. 2) were separately classified into maximum surge heights and surge plus storm waves. For a wider and denser spatial coverage, we combined our field measurements with the survey of Tajima et al. (2014). In both surveys, each high water mark indicator was referenced to the reconstructed tide level at the time of peak flooding. Heights differed by as much as $1 \mathrm{~m}$ at slightly different locations. Discrepancies of up to $2 \mathrm{~m}$ at corresponding locations were attributed to short-period storm waves superimposed on top of the surge. High water marks with significant storm-wave contributions were carefully identified based on eyewitness accounts, the type of physical watermark, and the inland location. Surge height measurements from different high water mark indicators in both surveys were mostly consistent.
At Tacloban, located some $23 \mathrm{~km}$ to the north of Haiyan's track (Fig. 2a), the characteristic height of the storm surge peak was $7 \mathrm{~m}$. Wave contributions raised high water marks up to almost $8 \mathrm{~m}$ in Tacloban and Palo. On the more open and exposed Pacific coastline at Hernani (Fig. 2c), some $45 \mathrm{~km}$ north of the typhoon track, significant storm-wave contributions resulted in high water marks exceeding $7 \mathrm{~m}$. Further amplification by the wave run-up on steep slopes such as near Guiuan resulted in a maximum run-up height of $14 \mathrm{~m}$ (Tajima et al. 2014). Surge heights exceeding $5 \mathrm{~m}$ were recorded along the shores of San Pedro Bay. We detail the nature of the storm surge in San Pedro Bay, where the highest death toll was recorded, in the next section. Outside of San Pedro Bay, but still within Leyte Gulf, the surge heights were only 3-4 m between Marabut and Quinapondan (Fig. 2b) because the storm track was parallel to the coastline. Water marks as high as $5 \mathrm{~m}$ were attributed to storm-wave contributions. In close proximity to Haiyan's landfall location between Tolosa and Dulag, the surge heights ranged between 3 and $5 \mathrm{~m}$ (Fig. 2a). At an exceptional site in Dulag, a 7-m-high water mark was compromised by significant storm-wave contribution. The lowest surge height of about $2 \mathrm{~m}$ was recorded at General MacArthur on the eastern coast of Samar (Fig. 2c). The site is sheltered behind fringing coral reefs located $3 \mathrm{~km}$ offshore and is on a bay with a narrow bottleneck entrance attenuating storm waves and resulting in a measurement dominated by the storm surge component.

Storm surge simulations of Typhoon Haiyan and Ty 1897 in San Pedro Bay. The Haiyan storm surge modeling results resolved an initial sea level drawdown around 2130 UTC 7 November 2013 (0530 PHT 8 November) in accordance with eyewitness accounts and the Tacloban tide gauge recording (Fig. 4). The tide gauge recorded a drawdown of at least $0.8 \mathrm{~m}$ before it broke down, ${ }^{2}$ while modeling suggests a drawdown of at least $1.2 \mathrm{~m}$ at the head of San Pedro Bay (Figs. 4a,b). The initial sea level drawdown was also observed at Basey on Samar (Amadore 2013). The drawdown was generated by persistent, strong, northerly offshore winds that initially drove the waters southward out of San Pedro Bay (Figs. 4a,b). Similar sea level drawdowns or negative surges from strong offshore winds during historic hurricanes have also been reported for the western Florida coasts (Harris 1963; Lawrence and Cobb 2005). The drawdown exposed

\footnotetext{
${ }^{2}$ The Tacloban tide data were provided by the National Mapping and Resources Information Agency (NAMRIA) of the Republic of the Philippines.
} 

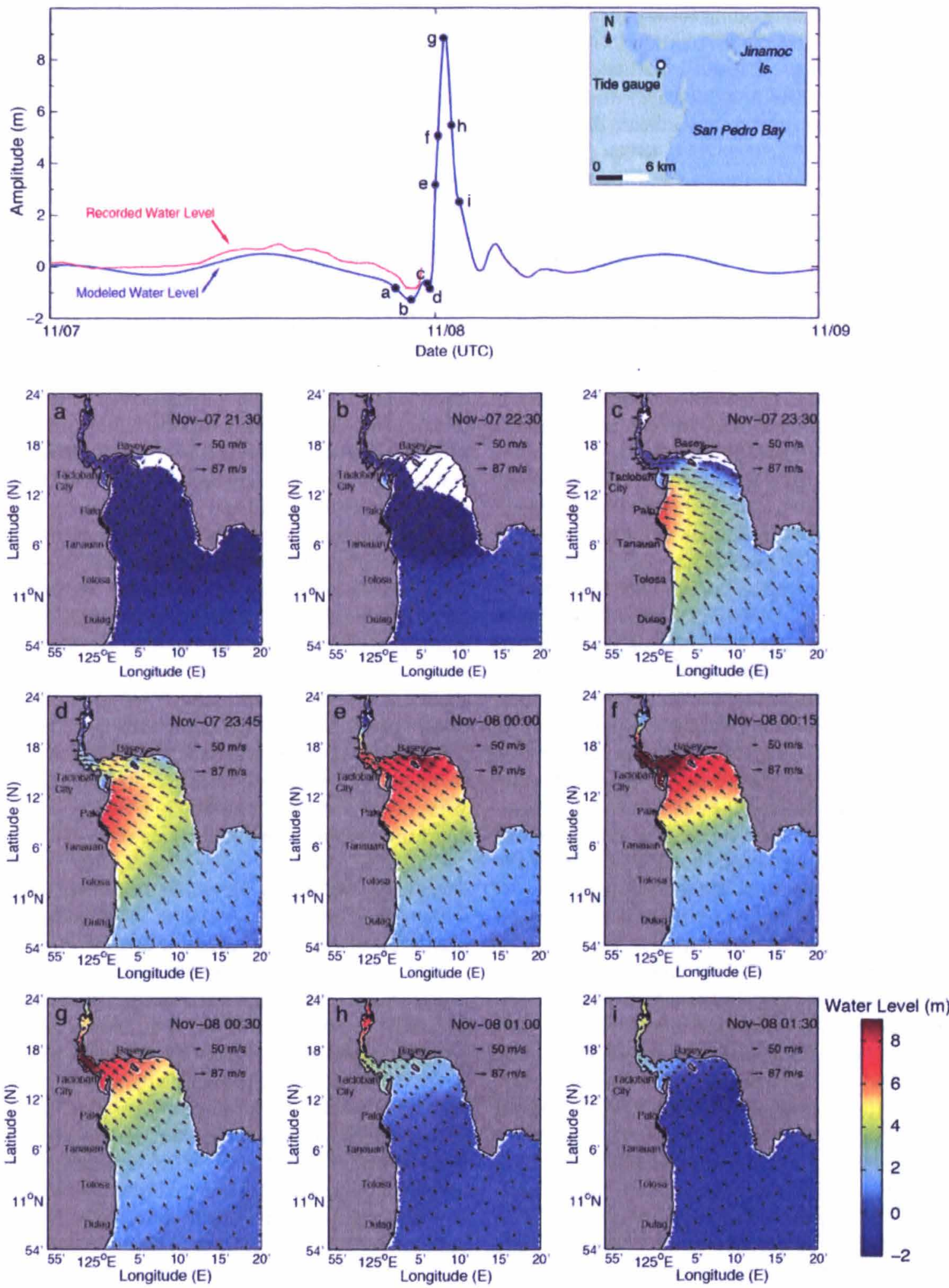

Fig. 4. Sea level heights in Tacloban and nearby coasts around San Pedro Bay during Typhoon Haiyan. (top) Graphical representation of the water levels from storm surge model (blue line) and from Tacloban Port tide gauge (red line). Both the actual and modeled tides show receding sea level prior to the peak surge. (a)-(i) Storm surge model sequence of Typhoon Haiyan in San Pedro Bay from 2130 UTC 7 Nov to 0130 UTC 8 Nov 2013 with colors and arrows representing water level and wind magnitude and direction, respectively. 
the seafloor and dramatically steepened the storm tide profile. This phenomenon is analogous to the negative leading $\mathrm{N}$-wave during tsunamis, usually resulting in a higher run-up (Tadepalli and Synolakis 1994). Eyewitness accounts and modeling show that the storm tide arrived as an unusually fast-moving "tsunami like" wave front, which caused high velocity coastal flooding to heights of more than $7 \mathrm{~m}$ near Tacloban and Basey. Residents in Basey, who stayed in their homes despite prior evacuation warnings, described a large wave similar to a tsunami striking soon after the water receded, providing only a few minutes of lead time to seek refuge at higher elevations.

The initial rise, peak, and lowering of flood levels
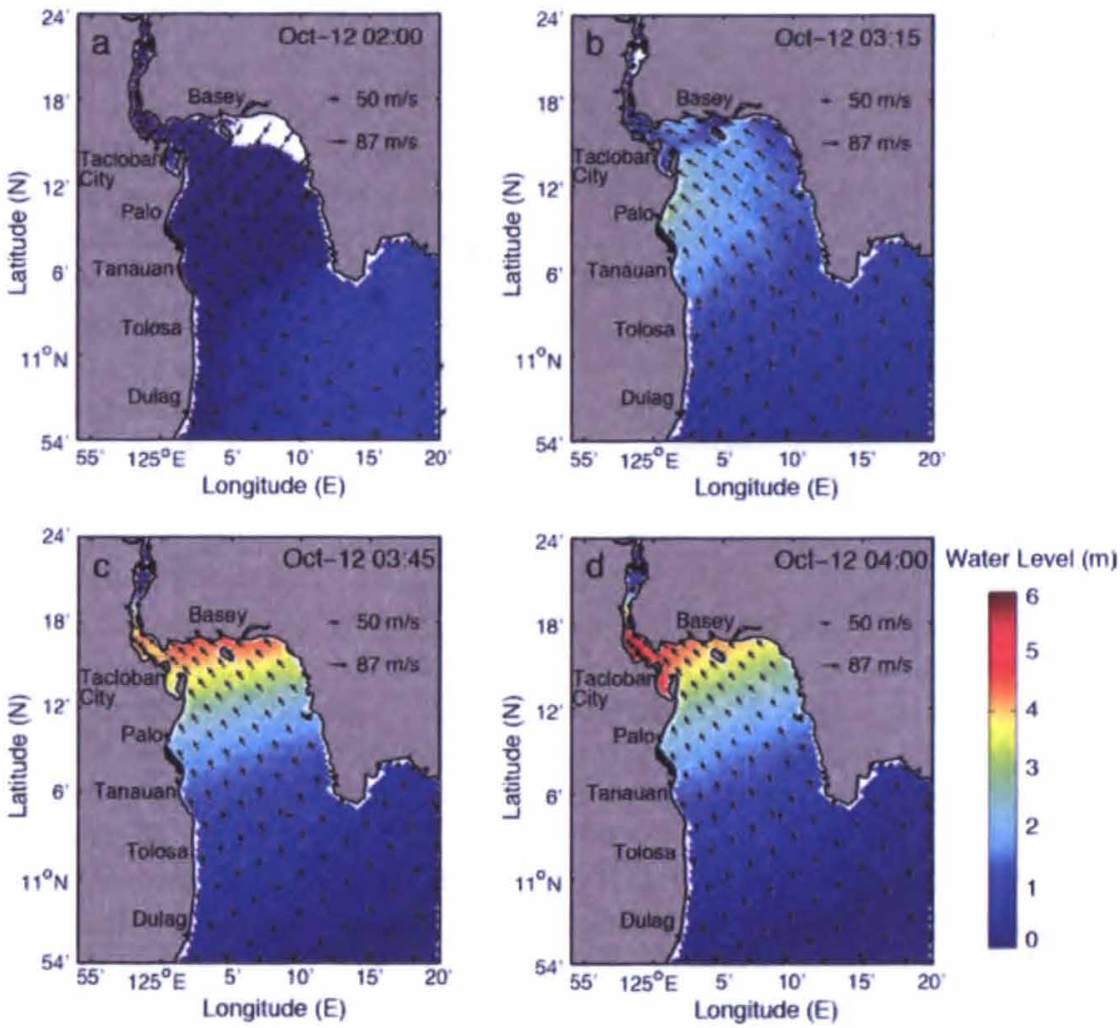

Fig. 5. Storm surge model sequence of Ty 1897 in San Pedro Bay from 0200 to 0400 UTC 12 Oct 1897 with colors and arrows representing water level and wind magnitude and direction, respectively.

due to the storm surge varied considerably in time and location. In downtown Tacloban, the peak surge occurred around 0000 UTC 8 November (0800 PHT 8 November), according to videos recorded by several eyewitnesses and the detailed coverage by storm chaser Morgerman (2014). The inundation timing was further confirmed by two wall clocks located about $14 \mathrm{~km}$ apart along the western shores of San Pedro Bay, which were stopped as seawater floods reached about 1.5-2 $\mathrm{m}$ high. In Tanauan, the clock stopped at 0720 PHT (2320 UTC 7 November); the clock in Tacloban City stopped a few minutes later at 0730 PHT (2330 UTC 7 November). The timing from the videos and wall clocks is consistent with the storm surge model. The modeled timing of the peak surge coincided with the timing of the onshore-directed winds closely linked to the forward motion of Typhoon Haiyan (Figs. 4c-g). The modeled peak surge of 6-8 m in San Pedro Bay occurred between 0000 and 0030 UTC (0800 and 0830 PHT) 8 November, arrived earlier along the eastern shores at the entrance of the bay, and propagated northward to the bay head. It is likely that several eyewitnesses in Dulag observed the front of the storm surge. During the passage of the eye (calm winds), eyewitnesses saw an offshore "wall of water" about $6 \mathrm{~m}$ high that first was moving west toward Dulag but then suddenly redirected north toward Tacloban. The peak surge lasted for at least $30 \mathrm{~min}$, and then just before 0100 UTC (0900 PHT) 8 November, the water subsided (Figs. $4 \mathrm{~h}-\mathrm{i}$ ).

In addition, the modeled water level in Fig. 4 shows three apparent peaks corresponding to points $\mathrm{C}, \mathrm{G}$, and after point $\mathrm{I}$. The peaks may coincide with the three "waves" reported by eyewitnesses (Amadore 2013; Morgerman 2014), although the timing could not be verified since the eyewitnesses did not track the timing of the three waves. In the open sea coast of Hernani, accounts of the storm surge coming in three waves also exist. The video footage from Hernani showed the building collapsing with the impact of the second wave, which corresponds to the highest and steepest peak in the storm surge model in San Pedro Bay.

The storm surge simulation of Ty 1897 (Fig. 5) showed water levels and peak surge timing that are consistent with Algués report (see the supplemental information online at http://dx.doi.org/10.1175 /BAMS-D-14-00245.2). In Basey, northnortheasterly offshore winds forced the water to 
recede (Fig. 5a). The initial rise of the surge occurred with the east-southeasterly winds (Fig. 5b), whereas south-southeasterly winds caused the peak surge in Tacloban and Basey (Figs. 5c,d). On the contrary, in Tolosa the model did not absolutely replicate the actual surge height. Algué reported surge height of $\sim 3 \mathrm{~m}$, but the model yielded $2 \mathrm{~m}$. The discrepancy can be attributed to various factors including changes in nearshore bathymetry, storm-wave contribution, and uncertainties in the Ty 1897 typhoon parameters. For the most part of San Pedro Bay, the modeled surges indicate that Ty 1897 generated lower surge heights than Typhoon Haiyan (Fig. 6), which is consistent with the field measurements for both storm surge events. The magnitude difference of the modeled surge heights between the two typhoons (Fig. 7) is also consistent with the magnitude difference of the measured water levels in both posttyphoon surveys.

IMPLICATIONS FOR DISASTER MANAGEMENT. Understanding the local storm surge hazard. The complex interactions among several factors including typhoon intensity represented

a)

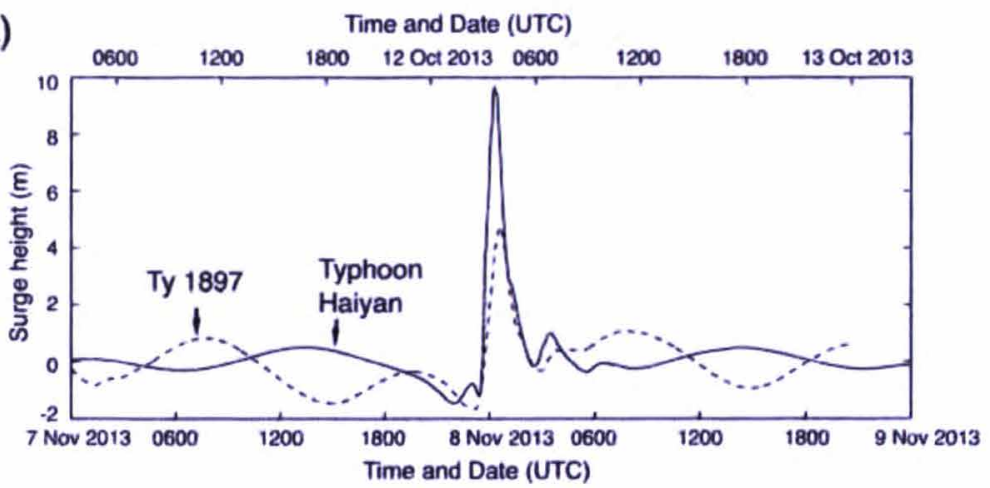

b)
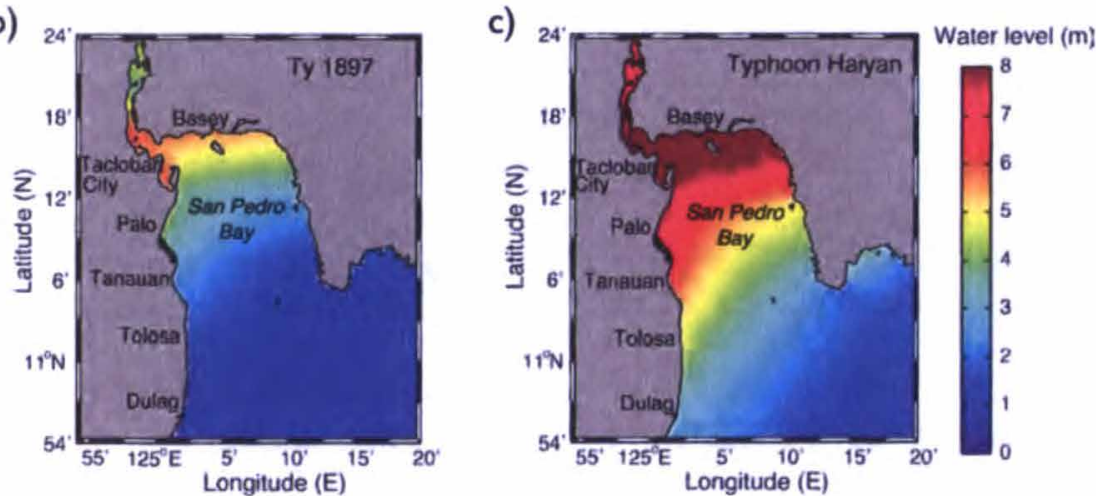

Fig. 6. Modeled surge heights comparison between Ty 1897 and Typhoon Haiyan in San Pedro Bay. (a) Graphical representation of the modeled water level at Tacloban for Ty 1897 and Typhoon Haiyan. (b) Modeled maximum surge heights in San Pedro Bay during Ty 1897. (c) Modeled maximum surge heights in San Pedro Bay during Typhoon Haiyan. by the lowest pressure and maximum wind speed, forward movement of the typhoon, storm size, bathymetry, coastline shape, and tidal phase result in varying storm surge height and flooding duration for any storm (e.g., Emanuel 2005a; Irish et al. 2008; Needham and Keim 2014). Given the similar areas impacted by the storm surges of Ty 1897 and Typhoon Haiyan, the coastal geomorphology is assumed to be relatively constant for these two events. Lander et al. (2014) estimated a $20-\mathrm{cm}$ sea level rise between 1970 and 2013, which likely did not contribute significantly to the impact of the storm surge from Typhoon Haiyan. The effect of sea level rise on the tidal phases of Ty 1897 and Typhoon Haiyan is beyond the scope of this study. We focused on differences in typhoon characteristics including track, intensity, size, and forward movement and their possible effect on the storm surge characteristics.

Despite the atmospheric differences between Ty 1897 and Typhoon Haiyan, the resulting two storm surges share notable similarities dictated by the local coastal configuration (Fig. 2). At exposed locations like Hernani, both typhoons generated peak surges exceeding $7 \mathrm{~m}$ with significant storm-wave contributions superimposed on top of the surge. In stark contrast, sheltered locations such as General MacArthur experienced the lowest flood levels with 2-m peak surges. Another similarity in both typhoons was the water receding off Basey in San Pedro Bay prior to the peak surge. Based on the historical accounts and our simulations, the $1.2-\mathrm{km}$-wide strait separating Jinamoc Island from Basey can be exposed as the water recedes prior to the peak surge given the shallow-water depth of $\sim 1.5$ m under normal conditions. In both typhoons, the surge in San Pedro Bay initially rose just before the typhoon made landfall on Leyte Island with easterly onshore winds. The surge then peaked with the southeasterly onshore winds as the typhoon eye 
moved west toward the interior of Leyte Island (Figs. 4, 5).

Irrespective of the coastal configuration, whether in exposed open sea (e.g., Hernani) or in a sheltered embayment (e.g., San Pedro Bay), the typhoon forward motion resulted in significantly different peak flooding duration between the two storm surge events. The slower forward motion of Ty 1897 resulted in longer peak floods lasting for about $3 \mathrm{~h}$. In contrast, the much-faster-moving Typhoon Haiyan resulted in rapid high velocity peak floods spanning about $30 \mathrm{~min}$ to nearly $1 \mathrm{~h}$.

The higher and more extensive peak surge around San Pedro Bay during Typhoon Haiyan compared to Ty 1897 (Fig. 6) could be due to the latitudinal shift of the typhoon tracks, differences in the intensity and forward motion of these two typhoons, or a combination of these factors. The northerly track of Ty 1897 made Tanauan the landfall location, reducing the surge near Palo and Tanauan; this is true especially given the relative absence of strong onshore winds when compared to Typhoon Haiyan. Meanwhile, the relatively more intense and larger Typhoon Haiyan generated stronger onshore winds on the northern and western shores of San Pedro Bay. The stronger onshore winds in turn induced surge heights almost twice those of Ty 1897, thereby extending over a wider region (Fig. 6).

Apart from typhoon intensity, the storm size was recognized as an additional important factor in generating high storm surges and extensive inundation during Hurricane Katrina (Irish et al. 2008). Given the geometry of San Pedro Bay, however, the storm size might not be an equally significant factor in generating high storm surges in the case of Typhoon Haiyan. The distance from the Typhoon Haiyan track to the head of San Pedro Bay is $\sim 40 \mathrm{~km}$, which is well within the zone of maximum winds. Although when considering the more southerly track of Typhoon Haiyan, the storm size likely contributed to the extreme surge heights along the more exposed coasts of eastern Samar such as at Hernani.

Multihazard evacuation strategies. Figure 8 shows the damage from Typhoon Haiyan surrounding San Pedro Bay. In the northern part of Tacloban, including the downtown area, the landward limit of inundation during Typhoon Haiyan exceeded $500 \mathrm{~m}$ (Tajima et al. 2014). Along low-lying, swampy areas south of downtown Tacloban, and similarly at Tanauan, inundation extended more than $2-\mathrm{km}$ inland. Overland flooding reached over $2 \mathrm{~km}$, but the primary areas of damage were concentrated within $200 \mathrm{~m}$ of the coast, highlighting that the destructive power of storm

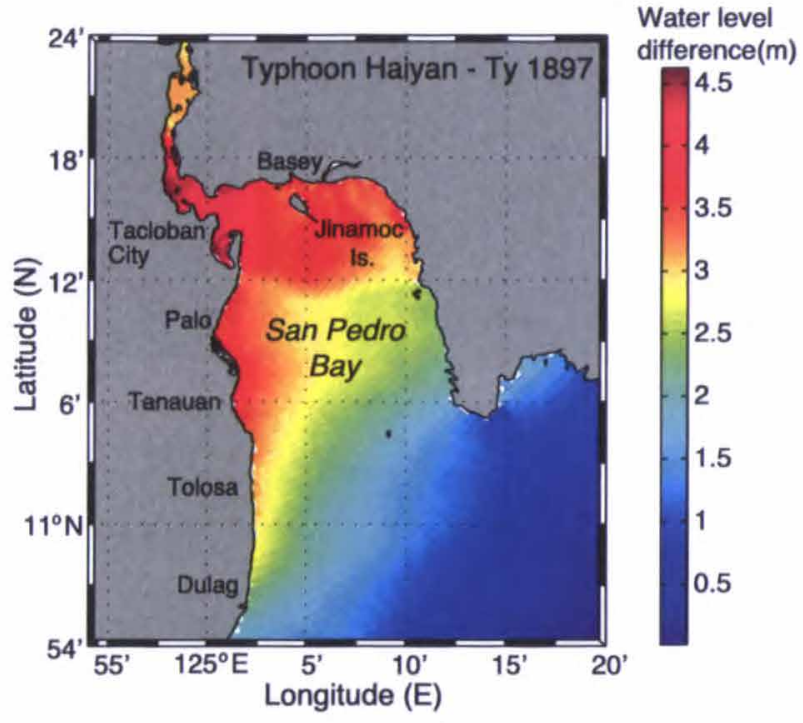

FIG. 7. Difference in water levels of the modeled maximum surge height between Ty 1897 and Typhoon Haiyan in San Pedro Bay.

waves riding on top of the storm surge has a limited inland penetration [Federal Emergency Management Agency (FEMA 2011). Very few structures withstood the energy of the storm surge and superimposed storm waves (Figs. 8b,c,d,f). In areas above the surge heights, extreme typhoon winds caused greater damage, destroying roofs and wide swaths of coconut trees (Fig. 8e). Therefore, the combined hazards from storm surge flooding, extreme winds, and the prevailing vulnerabilities must be considered when developing appropriate evacuation strategies.

Typhoon warning and response. The Philippine government issued typhoon forecasts and warnings for evacuations at least $18 \mathrm{~h}$ before Typhoon Haiyan's landfall to achieve minimum and possibly zero casualties from the imminently approaching cyclonic storm threat (Ranada 2013; NDRRMC 2013c; IRIDeS 2014). Preliminary social surveys suggest that local residents had a mixed response to the typhoon warnings emerging from complex social concerns (IRIDeS 2014; Leelawat et al. 2014). These studies highlight that communication pathways, warning systems, evacuation plans, and multilevel hazard and disaster perception were significant concerns for evacuation decisions among individuals in the areas severely impacted by Typhoon Haiyan. These findings underscore the need for the authorities responsible for disseminating weather warnings to better understand how typhoon warnings are transmitted from an initial source through intermediate relays to the final recipients, as well as how the potentially vulnerable 

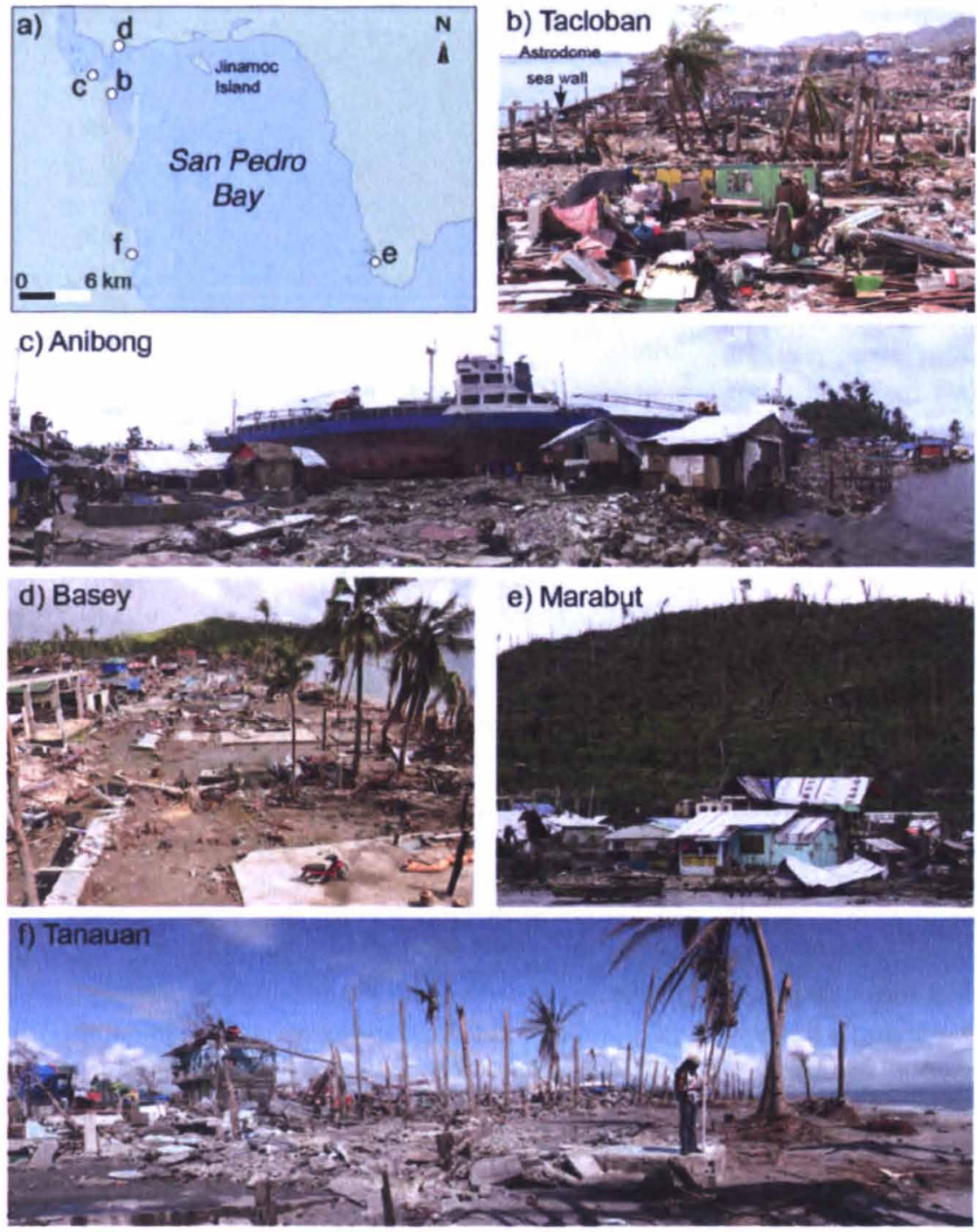

Fig. 8. Photos of storm damage around San Pedro Bay. (a) Location map. Most structures proximal to the coast in (b) Tacloban, (d) Basey, and (f) Tanauan were completely destroyed by the storm surge and the overriding storm waves. Like in most coastal settlements, existing guidelines on foreshore easement ${ }^{3}$ were completely ignored. (c) In Anibong village, just north of downtown Tacloban, stilt houses are rebuilt seaward of the stranded ships 2 months after the event. (e) In Marabut, wide swaths of palm trees chopped by the extreme winds.

that many people along the Gulf and Atlantic coasts in the United States have incorrectly believed that they have been through major cyclonic events, although Baker (1991) recognized that defining and measuring hurricane experience is a difficult task. Of particular relevance to the Philippines, several residents on Leyte and Samar Islands admitted that their experience of past typhoons misled them

residents receive, heed, interpret, and decide to act upon these warnings.

Given the historical perspective of storm surge hazards discussed in this paper, social scientists and historians may be able to improve local historical awareness about previous typhoon experiences to aid in hazard perception and response. Historical records show that several tropical cyclones have made landfall in the area surrounding Leyte Gulf (Fig. 9; Tables 3 and 4). According to an unpublished data of PAGASA4, nine of the tropical cyclones have generated storm surges (Table 3). Among these storms, residents identify the November 1984 Typhoon Agnes and the associated coastal flooding of more than 2-m deep in Samar and Leyte as the worst in living memory (e.g., Amadore 2013). Leik et al. (1981) noted to believe that an evacuation lead time of minutes would be sufficient. This raises a long-lasting question: How does the experience of smaller, relatively less impactful events shape the response of the community to larger, unprecedented events or those with return periods outside the living memory of residents?

On a broader note, although stronger prehistoric events (Donnelly et al. 2006; Nott 2007) remain to be explored, and as long as other historical events remain unverified, the Ty 1897 and Typhoon Haiyan storm surges may serve as worst-case scenarios for this region. These rare but disastrous events should be carefully evaluated toward enhancing community-based disaster risk awareness, planning, and response.

\footnotetext{
${ }^{3}$ The Water Code of the Philippines (Presidential Decree 1067) designates an easement of $40 \mathrm{~m}$ from seashore. This is supposed to be a "no build zone" area.
} 
CONCLUSIONS.

Historical records reveal a predecessor to Typhoon Haiyan occurred on 12 October 1897. This typhoon, referred to here as Ty 1897 , took a similar path of destruction through the eastern central Philippines. Ty 1897 and Haiyan had almost identical typhoon tracks, but Typhoon Haiyan was more intense, had larger maximum wind coverage, and moved faster than Ty 1897. Our combined field observations, eyewitness accounts, and computer simulations consistently indicate that Typhoon Haiyan's storm surge was about twice the height of the 1897 event in San Pedro Bay, but the two storm surges had similar heights on the open Pacific coast such as at Hernani. While stronger prehistoric events remain unexplored, Ty 1897 and Typhoon Haiyan storm surges may serve as extreme scenarios for this region in terms of disaster risk awareness, planning, and response.

\begin{tabular}{|c|c|c|c|c|}
\hline No. & Name & Date & Max winds (kt) & Min pressure $(\mathrm{hPa})$ \\
\hline 1 & No name & 12 Oct 1897 & & $\left(694 \mathrm{~mm}^{\mathrm{b}, \mathrm{c}}\right) 925$ \\
\hline 2 & No name & 4 May 1913 & & $\left(727.8 \mathrm{~mm}^{\mathrm{c}}\right) 970$ \\
\hline 3 & No name & 3 Jun 1923 & & $\left(739.52 \mathrm{~mm}^{\mathrm{c}}\right) 973$ \\
\hline 4 & $26 \mathrm{~W}$ & 14 Dec 1948 & $35^{2,}$ JTWC & \\
\hline 5 & Wanda & $23 \mathrm{Apr}$ 197I & $40^{2 . J M A}$ & $993^{\mathrm{a}, J M A}$ \\
\hline 6 & Agnes & 4 Nov 1984 & $100^{\mathrm{a}, J M A}$ & 925a, JMA \\
\hline 7 & Skip & 7 Nov 1988 & $70^{2 . J M A}$ & 955 a. JMA \\
\hline 8 & Mike & 12 Nov 1990 & $90^{\mathrm{a}, J \mathrm{MA}}$ & 935'. JMA \\
\hline 9 & Haiyan & 8 Nov 2013 & $125^{\text {a. JMA }}$ & $895^{\text {a. JMA }}$ \\
\hline
\end{tabular}

TABLE 4. Tropical cyclones with unknown storm surge occurrence (represented as white dashed lines in Fig. 9).

\begin{tabular}{|c|c|c|c|c|}
\hline No. & Name & Date & Max winds (kt) ${ }^{a}$ & Min pressure $(\mathrm{hPa})$ \\
\hline 1 & No name & $24 \operatorname{Nov} 1912^{d}$ & & $\left(693.08 \mathrm{~mm}^{\circ}\right) 923$ \\
\hline 2 & Wanda & 20 Nov 1951 & $90^{\text {a. JTWC }}$ & $985^{\text {a. JMA }}$ \\
\hline 3 & Wilma & 27 Oct 1952 & $130^{\mathrm{a}, \mathrm{JTWC}}$ & $930^{2, J M A}$ \\
\hline 4 & Tilda & 29 Nov 1954 & $120^{\mathrm{a}, J T W C}$ & $980^{\mathrm{a}, J M A}$ \\
\hline 5 & Irma & I5 May 1966 & $100^{\mathrm{a} . J T W C}$ & 974, JMA \\
\hline 6 & Jean & 14 July 197| & $75^{\text {a. JTWC }}$ & $980^{\text {a. JMA }}$ \\
\hline 7 & Kit & 7 Jan 1972 & $75^{\mathrm{a}, \text { JTWC }}$ & $975^{\text {a, JMA }}$ \\
\hline 8 & Nelson & $25 \operatorname{Mar} 1982$ & $105^{\text {a.jTWC }}$ & $940^{\text {a. JMA }}$ \\
\hline 9 & Axel & 21 Dec 1994 & $95^{\mathrm{a}, \mathrm{JTWC}}$ & $960^{2,}$ JMA \\
\hline
\end{tabular}

- IBTrACS database of Knapp et al. (2010) using either JTWC or JMA data.

'Data of Algué (1898).

' Data of Algué (1904)

- This Nov 1912 typhoon is believed to be deadly (http://chroniclingamerica.loc.gov/lccn/ sn83045433/19/2-11-30/ed-1/seq-1/), but other reports on the damage and impact to human life were insufficient for verification (U.S. War Office 1913).

- Data of Selga (1935).

ACKNOWLEDGMENTS. This research is supported by the National Research Foundation Singapore under its Singapore NRF Fellowship scheme (National Research Fellow Award NRF-RF2010-04) and administered by Earth Observatory of Singapore and the National Research Foundation Singapore and the Singapore Ministry of Education under the Research Centres of Excellence initiative. Additional funding for the Filipino scientists has come from the Department of Science and Technology, the Philippines. We thank Antonia

Fig. 9. Landfalling tropical cyclones in the surrounding area of Leyte Gulf between 1897 and 2013. Storm tracks were from the IBTrACS database of Knapp et al. (2010). The attributes of each typhoon are summarized in Tables 3 and 4.

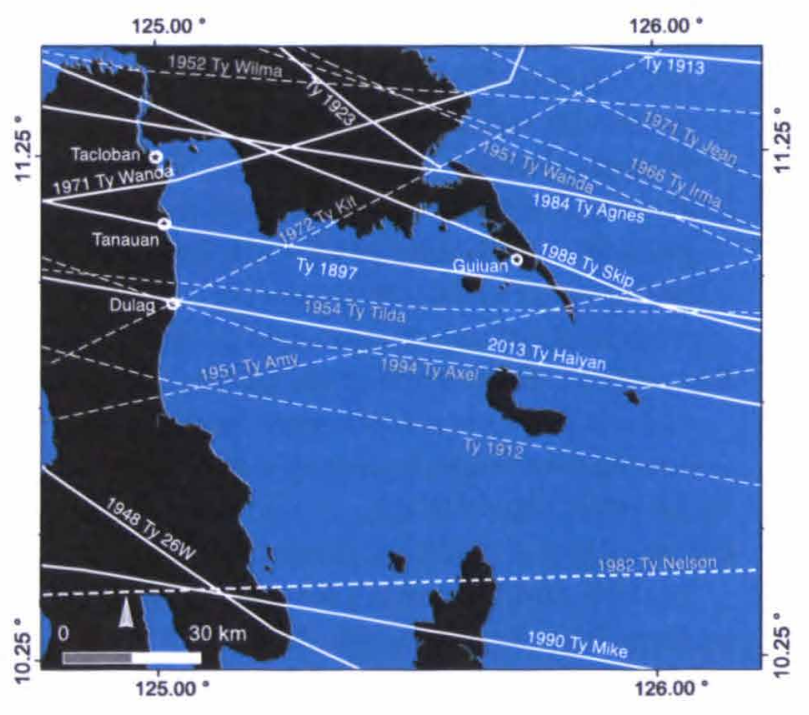


Yulo-Loyzaga of Manila Observatory, who provided the Algué report. We acknowledge John Elton Chua, Livre Lacierda, Mark Anthony Bamba, Mikko Garcia, Angel Doctor, and Sorvigenaleon Ildefonso for helping us gather data in the field. We are grateful to Chris Landsea and three anonymous reviewers, whose comprehensive and insightful reviews significantly improved the manuscript. Comments from Kelvin Rodolfo, Chris Gouramanis, and Aron Meltzner were valuable in refining the final version.

\section{REFERENCES}

Algué, J., 1898: El baguio de Samar y Leyte, 12-13 de Octubre de 1897. Manila Observatory, $74 \mathrm{pp}$.

- 1904: The Cyclones of the Far East. Bureau of Public Printing, $283 \mathrm{pp}$.

Alojado, D., and D. M. Padua, 2010: Worst typhoons of the Philippines 1947-2009. Accessed 06 July 2014: [Available online at www.typhoon2000.ph /stormstats/WorstPhilippineTyphoons.htm.]

Amadore, L. A., 2013: Storm surge in Basey, Samar. Accessed 03 April 2013. [Available online at http:// opinion.inquirer.net/66477/storm-surge-in-basey -samar.]

Atkinson, G. D., and C. R. Holliday, 1977: Tropical cyclone minimum sea level pressure/maximum sustained wind relationship for the western North Pacific. Mon. Wea. Rev., 105, 421-427, doi:10.1175/1520-0493(1977)105<0421:TCMSLP $>2.0 . \mathrm{CO} ; 2$.

Bacani, L., 2013: Deadliest, most destructive cyclones of the Philippines. Accessed 11 July 2014. [Available online at www.philstar.com/headlines /2013/11/11/1255490/deadliest-most-destructive -cyclones-philippines.]

Baker, E. J., 1991: Hurricane evacuation behavior. Int. J. Mass Emerg. Disasters, 9, 287-310.

Bricker, J., H. Takagi, E. Mas, S. Kure, B. Adriano, C. Yi, and V. Roeber, 2014: Spatial variation of damage due to storm surge and waves during Typhoon Haiyan in the Philippines. J. Japan Soc. Civil Eng., 70, 2, I_231-I_235.

Caulderwood, K., 2014: The ten most expensive natural disasters in 2013. Accessed 03 March 2014. [Available online at www.ibtimes.com/report-ten-most -expensive-natural-disasters-2013-1540058.]

Donnelly, C., N. Kraus, and M. Larson, 2006: State of knowledge on measurement and modeling of coastal overwash. J. Coastal Res., 22, 965-991, doi:10.2112/04-0431.1.

Dvorak, V. F., 1975: Tropical cyclone intensity analysis and forecasting from satellite imagery. Mon. Wea. Rev., 103, 420-430, doi:10.1175/1520 -0493(1975)103<0420:TCIAAF>2.0.CO;2.
- 1984: Tropical cyclone intensity analysis using satellite data. NOAA Tech. Rep. NESDIS 11, 50 pp. [Available online at $\mathrm{ftp}$ ://satepsanone.nesdis.noaa .gov/Publications/Tropical/Dvorak_1984.pdf.]

Egbert, G. D., and S. Y. Erofeeva, 2002: Efficient inverse modeling of barotropic ocean tides. J. Atmos. Oceanic Technol., 19, 183-204, doi:10.1175/1520 $-0426(2002) 019<0183$ : $\mathrm{EIMOBO}>2.0 . \mathrm{CO} ; 2$.

Emanuel, K. A., 2005a: The storm surge. Divine Wind: The History and Science of Hurricanes. Oxford University Press, 147-152.

- 2005b: The hunters. Divine Wind: The History and Science of Hurricanes. Oxford University Press, 193-202.

FEMA, 2011: Coastal construction manual: Principles and practices of planning, siting, designing, constructing, and maintaining residential buildings in coastal areas. U.S. Department of Homeland Security FEMA P-55, Vol. 1, 242 pp.

Flater, D., 1998: XTide: Harmonic tide clock and tide predictor. Accessed 25 May 2014. [Available online at www.flaterco.com/xtide/.]

Fritz, H. M., and Coauthors, 2007: Hurricane Katrina storm surge distribution and field observations on the Mississippi Barrier Islands. Estuarine Coastal Shelf Sci., 74, 12-20, doi:10.1016/j.ecss.2007.03 .015 .

- C. D. Blount, S. Thwin, M. K. Thu, and N. Chan, 2009: Cyclone Nargis storm surge in Myanmar. Nat. Geosci., 2, 448-449, doi:10.1038/ngeo558.

—, and Coauthors, 2012: The 2011 Japan tsunami current velocity measurements from survivor videos at Kesennuma Bay using LiDAR. Geophys. Res. Lett., 39, L00G23, doi:10.1029/2011GL050686.

Harris, D. L., 1963: Characteristics of the hurricane storm surge. U.S. Department of Commerce Weather Bureau Tech. Paper 48, 19-24. [Available online at https://coast.noaa.gov/hes/images/pdf /CHARACTERISTICS_STORM_SURGE.pdf.]

Holland, G. J., 1980: An analytic model of the wind and pressure profiles in hurricanes. Mon. Wea. Rev., 108, 1212-1218, doi:10.1175/1520 $-0493(1980) 108<1212$ :AAMOTW $>2.0 . C O ; 2$.

IRIDeS, 2014: Initial Report of International Research Institute of Disaster Science (IRIDeS): IRIDeS FactFinding Missions to Philippines. Tohoku University, 105 pp.

Irish, J.L., D. T. Resio, and J. J. Ratcliff, 2008: The influence of storm size on hurricane surge. J. Phys. Oceanogr., 38, 2003-2013, doi:10.1175/2008JPO3727.1.

Joint Typhoon Warning Center, 2014: JTWC western North Pacific best track data 2013. Joint Typhoon Warning Center, accessed 10 July 2014. [Available 
online at www.usno.navy.mil/NOOC/nmfc-ph/RSS /jtwc/best_tracks/wpindex.php.]

Knaff, J. A., and R. M. Zehr, 2007: Reexamination of tropical cyclone wind-pressure relationships. Wea. Forecasting, 22, 71-88, doi:10.1175/WAF965.1.

Knapp, K. R., and M. C. Kruk, 2010: Quantifying interagency differences in tropical cyclone best track wind speed estimates. Mon. Wea. Rev., 138, 1459-1473.

Knapp, K. R., M. C. Kruk, D. H. Levinson, H. J. Diamond, and C. J. Neumann, 2010: The International Best Track Archive for Climate Stewardship (IBTrACS): Unifying tropical cyclone best track data. Bull. Amer. Meteor. Soc., 91, 363-376, doi:10.1175/2009BAMS2755.1.

Koba, H., T. Hagiwara, S. Asano, and S. Akashi, 1990: Relationships between CI number from Dvorak's technique and minimum sea level pressure or maximum wind speed of tropical cyclone (in Japanese). J. Meteor. Res., 42, 59-67.

Kruk, M. C., K. R. Knapp, and P. A. Hennon, 2011: On the use of the Dvorak current intensity as a climate data record in the western North Pacific. 23rd Conf. on Climate Variability and Change, Seattle, WA, Amer. Meteor. Soc., 142. [Available online at https://ams.confex.com/ams/91Annual/webprogram /Paper179185.html.]

Lander, M., C. Guard, and S. J. Camargo, 2014: Super Typhoon Haiyan [in "State of the Climate 2013"]. Bull. Amer. Meteor. Soc., 95 (7), S112-S114.

Lawrence, $\mathrm{H}$., and H. Cobb, 2005: Tropical cyclone report: Hurricane Jeanne, 13-28 September 2004. Accessed 11 March 2014. [Available online at www.nhc .noaa.gov/data/tcr/AL112004_Jeanne.pdf.]

Leelawat, N., C. M. R. Mateo, S. M. Gaspay, A. Suppasri, and F. Imamura, 2014: Filipinos' views on the disaster information for the 2013 Super Typhoon Haiyan in the Philippines. Int. J. Sustainable Future Hum. Secur., 2 (2), 16-28.

Leik, R. K., T. M. Carter, J. P. Clark, S. D. Kendall, and G. A. Gifford, 1981: Community response to natural hazard warnings. Summary Final Rep. DCPA01-79-C-0214, FEMA Work Unit 2234-F, 77 pp. [Available online at http://oai.dtic.mil/oai/oai?verb $=$ getRecord $\&$ metadataPrefix $=$ html\&identifier $=A$ DA099509.]

Lesser, G. R., J. A. Roelvink, J. A. T. M. van Kester, and G. S. Stelling, 2004: Development and validation of a three-dimensional morphological model. Coastal Eng., 51, 883-915, doi:10.1016/j.coastaleng 2004.07.014.

Mas, E., J. Bricker, S. Kure, B. Adriano, C. Yi, A. Suppasri, and S. Koshimura, 2015: Field survey report and satellite image interpretation of the 2013
Super Typhoon Haiyan in the Philippines. Nat. Hazards Earth Syst. Sci., 15, 805-816, doi:10.5194 /nhess-15-805-2015.

Morgerman, J., 2014: Super Typhoon HAIYAN in Tacloban City \& Leyte, Philippines: Data \& documentation from the landfall zone of a category-5 cyclone. iCyclone Rep., 47 pp. [Available online at www.icyclone.com/upload/now/apr_2014/iCyclone _HAIYAN_in_Tacloban_City_040314.pdf.]

Mori, N., M. Kato, S. Kim, H. Mase, Y. Shibutani, T. Takemi, K. Tsuboki, and T. Yasuda, 2014: Local amplification of storm surge by Super Typhoon Haiyan in Leyte Gulf. Geophys. Res. Lett., 41, 51065113, doi:10.1002/2014GL060689.

Nakazawa, T., and S. Hoshino, 2009: Intercomparison of Dvorak parameters in the tropical cyclone datasets over the western North Pacific. SOLA, 5, 33-36, doi:10.2151/sola.2009-009.

National Mapping and Resource Information Authority, 1980: Nautical chart of San Pedro Bay. 1:402000. Sheet 4468

NDRRMC, 2013a: Preparations for Typhoon "YOLANDA" (HAIYAN). NDRMMC Situational Rep. 2, 10 pp. [Available online at www.ndrrmc gov.ph/attachments/article/1329/Preparations _for_Typhoon_YOLANDA_(HAIYAN)_Sit Rep _No_02_07NOV2013_0600H.pdf.]

- , 2013b: Effects of Typhoon "YOLANDA" (HAIYAN). NDRRMC Situational Rep. 10, 43 pp. [Available online at www.ndrrmc.gov.ph/attachments /article/1329/Effects_of_Typhoon_YOLANDA _(HAIYAN)_SitRep_No_10_10NOV2013_0600H .pdf.]

- 2013c: Preparations for Typhoon "YOLANDA" (HAIYAN). NDRMMC Situational Rep. 3, 13 pp. [Available online at www.ndrrmc.gov.ph/attachments /article/1329/Preparations_for_Typhoon_YOLANDA _(HAIYAN)_SitRep_No_03_07NOV2013_0000H.pdf.] _ 2014: Effects of Typhoon "YOLANDA" (HAIYAN). Situational Rep. 108, 67 pp. [Available online at www.ndrrmc.gov.ph/attachments/article/1329 /Effects_of_Typhoon_YOLANDA_(HAIYAN) _SitRep_No_108_03APR2014.pdf.]

Needham, H. F., and B. D. Keim, 2014: Correlating storm surge heights with tropical cyclone winds at and before landfall. Earth Interact., 18, doi:10.1175/2013EI000527.1.

Nott, J., 2007: The importance of quaternary records in reducing risk from tropical cyclones. Palaeogeogr. Palaeoclimatol. Palaeoecol., 251, 137-149, doi:10.1016 /j.palaeo.2007.02.024.

Paciente, R. B., 2014: Response and lessons learned from Typhoon "Haiyan" (Yolanda). JMA/WMO Workshop 
on Effective Tropical Cyclone Warning in Southeast Asia, Session 6: Effective Early Warning: Lessons learnt from past TC Disasters. Tokyo, Japan, Japan Meteorological Agency. [Available online at www .jma.go.jp/jma/jma-eng/jma-center/rsmc-hp-pub -eg/2014_Effective_TC_Warning/documents.html.

Ranada, P., 2013: Leyte warned of storm surges. Accessed 10 November 2013. [Available online at www .rappler.com/nation/43179-yolanda-storm-surges.]

Ribera, P., R. García-Herrera, and L. Gimeno, 2008: Historical deadly typhoons in the Philippines. Weather, 63, 194-199, doi:10.1002/wea.275.

Selga, M., 1935: Charts of remarkable typhoons in the Philippines 1902-1934. Catalogue of Typhoons 1348-1934, Manila Weather Bureau, 1-55.

Tadepalli, S., and C. E. Synolakis, 1994: The run-up of $\mathrm{N}$-waves on sloping beaches. Proc. Roy. Soc. London, A445, 99-112, doi:10.1098/rspa.1994.0050.

Tajima, Y., and Coauthors, 2014: Initial report of JSCEPICE joint survey on the storm surge disaster caused by Typhoon Haiyan. Coastal Eng. J., 56, 1450006, doi:10.1142/S0578563414500065.
Udías, A., 1996: Jesuits' contribution to meteorology. Bull. Amer. Meteor. Soc., 77, 2307-2315, doi:10.1175/1520 $-0477(1996) 077<2307:$ JCTM>2.0.CO;2.

UNESCO, 2014: International Tsunami Survey Team (ITST) post-tsunami survey guide. UNESCOIOC Manuals and Guides 37, $114 \mathrm{pp}$. [Available online at http://unesdoc.unesco.org/images/0022 /002294/229456E.pdf.]

U.S. War Office, 1913: Typhoons. Report of the Philippine Commission to the Secretary of War, Washington Government Printing Office, 32.

Velden, C., and Coauthors, 2006: The Dvorak tropical cyclone intensity estimation technique: A satellitebased method that has endured for over 30 years. Bull. Amer. Meteor. Soc., 87, 1195-1210, doi:10.1175 /BAMS-87-9-1195.

World Meteorological Organization, 2015: Typhoon committee operational manual: Meteorological component. Tropical Cyclone Programme Rep. TCP23, 169 pp. [Available online at www.wmo.int/pages /prog/www/tcp/documents/TCP-23EDITION2015 .pdf.]

\section{CLIMATE CHANGE/POLICY}

" This book is timely because global climate change policy is a mess.... Drawing on concrete examples and a broad range of social science theory, this book convincingly makes the case for a social learning approach to both adaptation and emissions mitigation."

- Steve Rayner, James Martin Professor of Science and Civilization, University of Oxford

\section{Adaptive Governance and Climate Change}

RONALD D. BRUNNER AND AMANDA H. LYNCH

As greenhouse gas emissions and temperatures at the poles continue to rise, so do damages from extreme weather events affecting countless lives. Meanwhile, ambitious international efforts to cut emissions have proved to be politically ineffective or infeasible. There is hope, however, in adaptive governance - an approach that has succeeded in some communities and can be undertaken by others around the globe.

In this book:

- A political and historical analysis of climate change policy

- How adaptive governance works on the ground

- Why local, bottom-up approaches should complement global-scale negotiations 


\section{APPENDIX 2}

Storm surge occurrences in the Philippines 1897-1998 


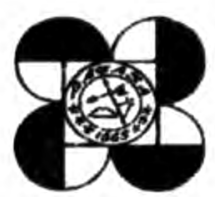

\author{
Philippine Atmospheric, Geophysical and \\ Department of Science and Technology \\ Astronomical Services Administration (PAGASA) \\ ASIATRUST Bank Bldg, 1424 Quezon Avenue \\ Quezon City, Philippines
}

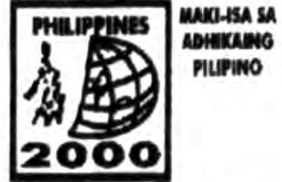

STAND Phillippines 2000

CLIMATOLOGY AND AGROMETEOROLOGY BRANCH

Climate Change, Drought Early Warning and Monitoring Center

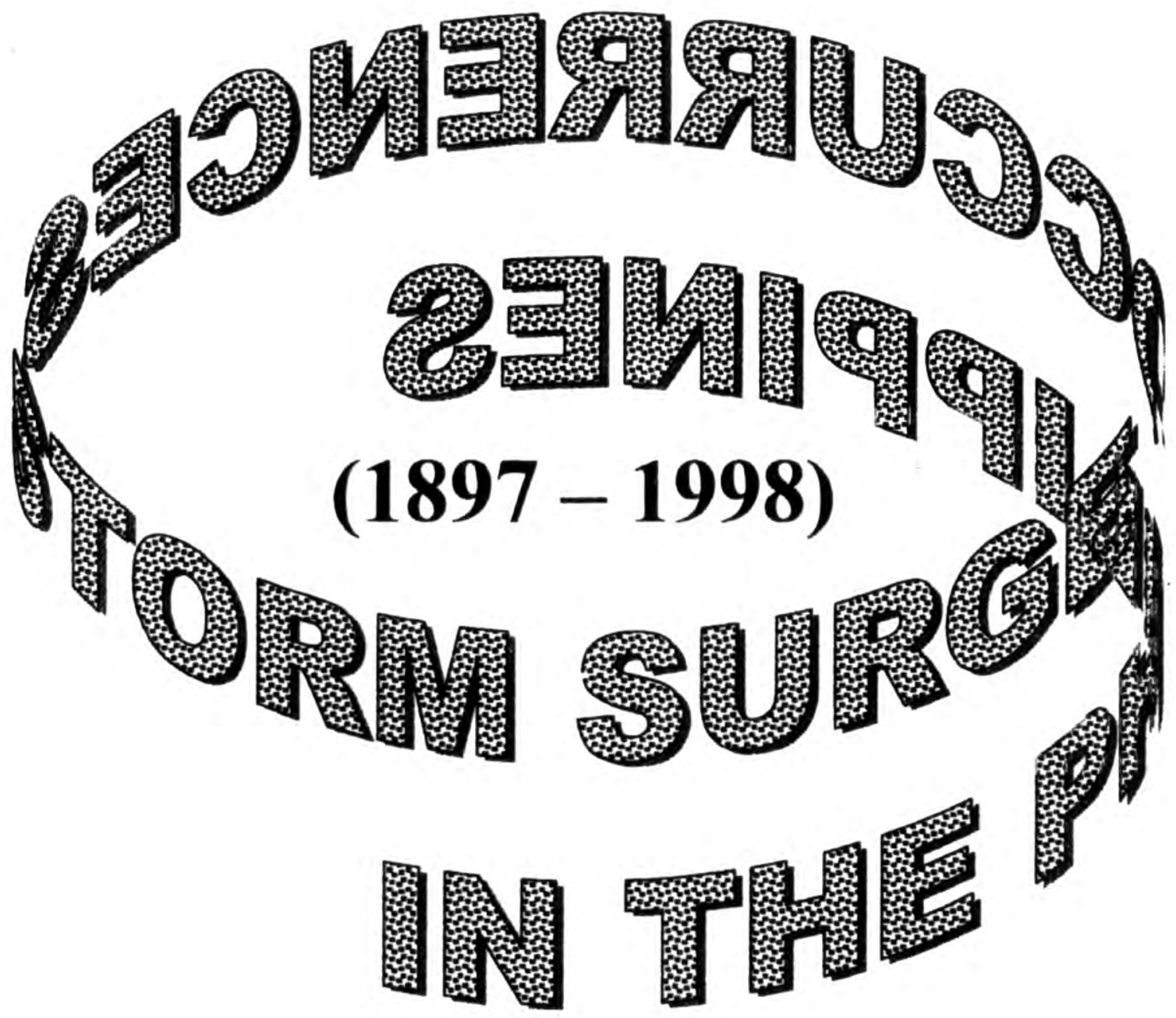

Prepared: February 29, 2000

vem iii.. 


\begin{tabular}{|c|c|c|c|}
\hline NAME OF T.C. AND DATES IN WHICH & OBSERVED & AFFECTED COASTAL & ACTUAL STORM \\
\hline THE SURGE IS ASSOCIATED WITH & MAX WINDS(kph) & AREAS -TOWN/PROVINCE & SURGE HEIGHT(M) \\
\hline 1) Typhoon of Samar and Leyte & & Banay,Samar & $4.4 \mathrm{M}$ \\
\hline \multirow[t]{4}{*}{ October 12,1897} & & Hernani,Tanglad, Samar & $73 \mathrm{M}$ \\
\hline & & Pambujan, Samar & $1.5 \mathrm{M}$ \\
\hline & & Basey. Samar & $4.9 \mathrm{M}$ \\
\hline & & Tacloban, Leyte & $0.9 \mathrm{M}$ \\
\hline & & & \\
\hline 2) Typhoon & & Mamburao, Mindoro & $1.5 \mathrm{M}$ \\
\hline \multicolumn{4}{|l|}{ May $15-19,1901$} \\
\hline \multirow{5}{*}{ 3) 1904} & & Bacolod & UND \\
\hline & & Dipolog & UND \\
\hline & & Nonoc Isaland, surigao & UND \\
\hline & & Placer, Surigao, City & UNO \\
\hline & - & & \\
\hline 4) Typhoon & & Manila Area and Vicinity & UND \\
\hline \multicolumn{4}{|l|}{ September 25 - 27, 1905} \\
\hline & & & \\
\hline 5) Typhoon in W. Carolines & & Borongan, Samar & UND \\
\hline \multicolumn{4}{|l|}{ Januaiy 1907} \\
\hline & & & \\
\hline 6) Typhoon of Samar & & Tuminobo and Ando is., & UND \\
\hline September $22-25,1908$ & & Borongan, Samar & \\
\hline 7) Typhoon of Cagayan & & Aparri, Cagayan & $2.4 \mathrm{M}$ \\
\hline \multicolumn{4}{|l|}{ October $11-13,1908$} \\
\hline 8) Typhoon of Cagayan and & & San Vicente, Cagayan & UND \\
\hline Batanes Is . September $27-29,1912$ & & \& Palaui Island & \\
\hline 9) Typhoon of Leyte \& Cebu & & Sogod, Northern Leyte & $9.1 \mathrm{M}$ \\
\hline \multirow[t]{2}{*}{ October $15-16,1912$} & & Consolacion, Cebu & \\
\hline & & Malitbog, Northern Leyte & $4.6 \mathrm{M}$ \\
\hline 10) Typhoon of Samar, Leyte \& & & All towns and Barrios & UND \\
\hline \multirow[t]{2}{*}{ Panay, November 24-25,1912 } & & along Maqueda Bay in & \\
\hline & & Samar & \\
\hline 11) Typhoon of Samar, Leyte \& & & Coastal Barrios in Hernani, & UND \\
\hline \multirow[t]{4}{*}{ llocos, May 4-11, 1913} & & Llorente and Pambuyan in & \\
\hline & & Samar, parts of Tacloban. & \\
\hline & & Sinait, Cabugao \& Narva- & \\
\hline & & can, llocos Sur & \\
\hline 12) Typhoon of Samar \& Luzon, & & Tubabao, Hilaban \& & $2.3 \mathrm{M}$ \\
\hline June $17-21,1914$ & & Dolores, Samar & \\
\hline 13) Typhoon of Biliran \& Northern & & Merida, Leyte & UND \\
\hline Leyte, January $14-16,1916$ & & & \\
\hline & & & \\
\hline
\end{tabular}




\begin{tabular}{|c|c|c|c|}
\hline NAME OF T.C. AND DATES IN WHICH & OBSERVED & AFFECTED COASTAL & ACTUAL STORM \\
\hline THE SURGE IS ASSOCIATED WITH & MAX WINDS(kph) & AREAS -TOWN/PROVINCE & SURGE HEIGHT(M) \\
\hline 14) Typhoon & & Bagac,Morong, Bataan & $8.0 \mathrm{M}$ \\
\hline \multicolumn{4}{|l|}{ August 1, 1920} \\
\hline 15) Typhoon of Samar,Leyle \& & & Eastern coast of Samar & UND \\
\hline \multicolumn{4}{|l|}{ Southern Luzon, June 3-4,1923 } \\
\hline 16) Tropical Storm & & Calapan, Mindoro & UND \\
\hline \multirow[t]{2}{*}{ November 28-03 December 1924} & & Carcar, Naga & UND \\
\hline & & Mabibi, Boholl & UND \\
\hline 17) Typhoon of Bicol & & Paracale. Cam. Norte & UND \\
\hline \multicolumn{4}{|l|}{ June $24-26,1925$} \\
\hline 18) Typhoon of Visayas & & Sibuyan Island and & UND \\
\hline December 3-8, 1930 & & Busuanga, Culion & \\
\hline 19) Typhoon of Visayas & & Camotes Island, Borbon & UND \\
\hline January $2-5,1931$ & & in Cebu & \\
\hline 20) Typhoon & & East Coast, Borongan, Samar & $9.8 \mathrm{M}$ \\
\hline \multicolumn{4}{|l|}{ November $1-4,1933$} \\
\hline 21) Typhoon of Visayas & & Dulog, I.eyte & UND \\
\hline \multicolumn{4}{|l|}{ November $2 \cdot 5,1934$} \\
\hline 22) 1944 & & Solvec, llocos Sur & $10 \mathrm{M}$ \\
\hline 23) Typhoon & & Tacloban, Leyte & UND \\
\hline \multicolumn{4}{|l|}{ December $12-16,1948$} \\
\hline 24) Typhoon Nona & & Currimao, llocos Norte & UND \\
\hline \multicolumn{4}{|l|}{ August 31 - 05 September 1952} \\
\hline 25) Typhoon Nora & & Banawe, Bangar, llocos, Sur & UND \\
\hline \multicolumn{4}{|l|}{ September $5-12,1959$} \\
\hline & & & \\
\hline 26) Typhoon Harriet & 225- Virac, & Coastal areas of Bicol & UND \\
\hline December 29, 1959 & Catanduanes & and Visayas & \\
\hline 27) Typhoon Karen & 65-Surigao & Visayas & UND \\
\hline \multicolumn{4}{|l|}{ April 25,1960 } \\
\hline 28) Typhoon Olive & 185-Legaspi City & Manila & UND \\
\hline \multicolumn{4}{|l|}{ June $23-28,1960$} \\
\hline 29) Typhoon Kit & 185-Calapan, & Legaspi City & UND \\
\hline October $3-9,1960$ & Or. Mindoro & & \\
\hline & & & \\
\hline & & & \\
\hline
\end{tabular}




\begin{tabular}{|c|c|c|c|}
\hline NAME OF T.C. AND DATES IN WHICH & OBSERVED & AFFECTED COASTAL & ACTUAL STORM \\
\hline THE SURGE IS ASSOCIATED WITH & MAX WINDS(kph) & AREAS -TOWN/PROVINCE & SURGE HEIGHT(M) \\
\hline 30) Typhoon Kate & 104-Port Area, & West coast of Luzon & UND \\
\hline July $9-22,1962$ & Manila & & \\
\hline 31) Typhoon Karing & 67-Port Area & Luzon Coast & UND \\
\hline \multicolumn{4}{|l|}{ June $12-18,1963$} \\
\hline 32) Typhoon Dading & 127-Infanta & Manila, Cavite \& & UND \\
\hline June $26-30,1964$ & & Paranaque & \\
\hline 33) Typhoon Ining(Louise) & 230-over water & Surigao del Norte \& & UND \\
\hline November $16-21,1964$ & & Bacolod & \\
\hline 34) Typhoon Miling(Freda) & 176-Tuguegarao & Manila & UND \\
\hline July $9-14,1965$ & Cagayan & & \\
\hline 35) Typhoon Klaring(Irma) & 195-Tacloban, & Masbate & \\
\hline May $11-12,1966$ & Leyte & 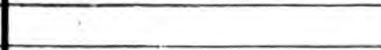 & \\
\hline . & & & \\
\hline 36) Typhoon Gening (Anita) & 106-Laoag City & San Nicolas, Batac \& & UND \\
\hline June $26-29,1967$ & & Paoay, llocos Norte & \\
\hline 37) Typhoon Didang & 158-Basco, & Solvec, Narvacan, I. S., & $9.0 \mathrm{M}$ \\
\hline July $21-28,1968$ & Batanes & Sta. Cruz \& Mamburao & \\
\hline 38) Typhoon Elang (Viola) & 222-Basco, & Manila, Coastal towns of & \\
\hline July $26-29,1969$ & Batanes & Bauang \& Sudipen, L.U. & \\
\hline 39) Typhoon Atang (Nancy) & 230-Virac, Cat. & Catbalogan, Samar & UND \\
\hline \multicolumn{4}{|l|}{ February 23-27, 1970} \\
\hline 40) Typhoon Emang (Ruby) & 90-Northern & Eastern coasts of Cagayan, & UND \\
\hline July $11-15,1970$ & Quezon & Babuyan Is \& Catanduanes & \\
\hline 41) Typhoon Pitang (Georgia) & 240 -over water & Casiguran, Aurora; and & UND \\
\hline \multirow[t]{2}{*}{ September 8-12, 1970} & & Disalag \& Dipaculag. & \\
\hline & & Quezon & \\
\hline 42) Typhoon Sening (Joan) & 225-Catanduanes & Cavite Sorsooon Ilocos Sur. & $3.0-5.0 \mathrm{M}$ \\
\hline October $10-15,1970$ & & Bagac, Morong, Bataan & \\
\hline 43) Typhoon Yoling (Patsy) & 200-MIA & Calagua Is. Manila Bay, & \\
\hline November $17-20,1970$ & & Cavite,Katakian Is. in Polillo. & \\
\hline 44) Typhoon Diding (Wanda) & 160-Tacloban & Guiuan Is. \& Palo-Palo & UND \\
\hline April 23-28, 1971 & & in Samar & \\
\hline 45) Typhoon Herming (Dinah) & 150-Legaspi City & Dalahican, Lucena & UND \\
\hline May $25-27,1971$ & & & \\
\hline & & & \\
\hline
\end{tabular}




\begin{tabular}{|c|c|c|c|}
\hline NAME OF T.C. AND DATES IN WHICH & OBSERVED & AFFECTED COASTAL & ACTUAL STORM \\
\hline THE SURGE IS ASSOCIATED WITH & MAX WINDS(kph) & AREAS -TOWN/PROVINCE & SURGE HEIGHT(M) \\
\hline 46) Typhoon Rosing & 190-Basco, & Manila & UND \\
\hline July $16-21,1971$ & Batanes & & \\
\hline 47) Typhoon Uring (Rose) & 139-Tuguegarao, & llocos, Pangasinan \& & UND \\
\hline August $11-14,1971$ & Cagayan & Zambaies Provinces & \\
\hline 48) Typhoon Barang (Elaine) & 95-Virac, Cat. & From llocos Sur to Bataan, & UND \\
\hline September 31-October 6, 1971 & & Batangas and Palawan & \\
\hline 49) Typhoon Dadang & 78-Calapan & Cavite and Las Pinas & UND \\
\hline October $1-9,1971$ & Or. Mindoro & & \\
\hline 50) Typhoon Asiang (Kit) & 104-Tacloban & Abuyog \& Baybay, Leyte & LND \\
\hline \multicolumn{4}{|l|}{ January $5-9,1972$} \\
\hline 51) Tropical Storm Edeng(Susan) & 55-over water & Manila Bay & UND \\
\hline \multicolumn{4}{|l|}{ July 7,1972} \\
\hline 52) Typhoon Gloring(Rita) & 273-over water & Manila Bay & UND \\
\hline \multicolumn{4}{|l|}{ July 10,1972} \\
\hline 53) Typhoons Huaning \& Isang & 40-Virac, Cat. & Batanes Island & UND \\
\hline \multicolumn{4}{|l|}{ July 29-August 1, 1972} \\
\hline 54) Typhoon Auring (Lola) & 110-Mactan & Surigao del Sur & UND \\
\hline \multicolumn{4}{|l|}{ January $22-23,1975$} \\
\hline 55) Typhoon Atang & 180-Romblon & San Vicente, Cagayan. & UND \\
\hline April $18-27,1978$ & & Bataan \& Itbayat Island & \\
\hline 56) Typhoon Daling(Kelly 8106) & 150-Virac, Cat. & Calapan,Naujuan,Socorro, & UND \\
\hline \multirow[t]{2}{*}{ June 28-July 5, 1981} & & Pola,Pinamalayan,Gloria, & \\
\hline & & Mindoro Oriental & \\
\hline 57) Typhoon Anding(Irma 8126) & 260-Daet & Binagasbasan,Garchitorena & $8.2 \mathrm{M}$ \\
\hline \multirow[t]{8}{*}{ November 22-27, 1981} & 240-Recon & Poblacion & $2.9 \mathrm{M}$ \\
\hline & & Sta. Cruz, Lagonoy & $2.2 \mathrm{M}$ \\
\hline & & Port Tambang,Tinambac & $4.0 \mathrm{M}$ \\
\hline & & Poblacion, Tinambac & $4.4 \mathrm{M}$ \\
\hline & & Digisit, Baler & $8.4 \mathrm{M}$ \\
\hline & & Cemento, Baler & $4.0 \mathrm{M}$ \\
\hline & & Tibag, Baler & $2.7 \mathrm{M}$ \\
\hline & & Sabang, Baler & \\
\hline 58) Typhoon Norming & 220- Iba, Zambales & Orani, Bataan & $8 \cdot 1.7 \mathrm{M}$ \\
\hline August $19-07$ September 1982 & 150-over water & & \\
\hline & & & \\
\hline & & & \\
\hline & & & \\
\hline
\end{tabular}




\begin{tabular}{|c|c|c|c|}
\hline NAME OF T.C. AND DATES IN WHICH & OBSERVED & AFFECTED COASTAL & ACTUAL STORM \\
\hline THE SURGE IS ASSOCIATED WITH & MAX WINDS(kph) & AREAS -TOWN/PROVINCE & SURGE HEIGHT(M) \\
\hline 59) Typhoon Bebeng(Vera 8303) & 165-MIA & Bacon, Sorsogon & $2.9 \mathrm{M}$ \\
\hline \multirow[t]{8}{*}{ July $12-16,1983$} & & Bulabog, Sorsogon & $33 \mathrm{M}$ \\
\hline & & Albay & $0.65 \mathrm{M}$ \\
\hline & & Cabcaben,Bataan & \\
\hline & & Limay, Bataan & $0.98 \mathrm{M}$ \\
\hline & & Orion, Bataan & $0.78 \mathrm{M}$ \\
\hline & & Baianga, Bataan & $1.9 \mathrm{M}$ \\
\hline & & Orani. Bataan & $1.41 \mathrm{M}$ \\
\hline & & Manila Bay & $0.66 \mathrm{M}$ \\
\hline 60) Typhoon Warling(Orchid 8303) & 220-Recon & Infanta, Quezon & $4.52 \mathrm{M}$ \\
\hline November $17-27,1983$ & 150-Virac, Cat. & General Nakar, Quezon & $4.82 \mathrm{M}$ \\
\hline 61) Typhoon Nitang(Ike 8411) & 220-Surigao City & San Fernando, Cebu & $3.25 \mathrm{M}$ \\
\hline \multirow[t]{9}{*}{ August 31-September 4, 1984} & & Placer,Surigao del Norte & $2.39 \mathrm{M}$ \\
\hline & & Talisay Nonoc is. & $3.2 \mathrm{M}$ \\
\hline & & Surigao City & $3.53 \mathrm{M}$ \\
\hline & & Lake Mainit & $2.83 \mathrm{M}$ \\
\hline & & Sogod, Sin Leyte & $3.27 \mathrm{M}$ \\
\hline & & Lugsongan, Limasawa is. & $4.64 \mathrm{M}$ \\
\hline & & Magallanes & $4.57 \mathrm{M}$ \\
\hline & & Padre Burgos, Sin Leyte & $316 \mathrm{M}$ \\
\hline & & Mabini, Bohol & $2.87 \mathrm{M}$ \\
\hline 62) Typhoon Undang(Agnes8424) & 230-Tacloban & Hernani, Eastern Samar & $2.82 \mathrm{M}$ \\
\hline \multirow[t]{7}{*}{ November $3-6,1984$} & 205-Recon & Llorente & $2.65 \mathrm{M}$ \\
\hline & & Balangkayan & $4.5 \mathrm{M}$ \\
\hline & & Suribao & $4.4 \mathrm{M}$ \\
\hline & & Basey. Samar & $2.38 \mathrm{M}$ \\
\hline & & Babatnon, Leyte & $2.15 \mathrm{M}$ \\
\hline & & San Jose, Tac., Leyte & $2.17 \mathrm{M}$ \\
\hline & & Sogod, Sin Leyte & $1.84 \mathrm{M}$ \\
\hline 63) Typhoon Saling (Dot 8522) & 240-Recon & Infanta, Quezon & $3.46 \mathrm{M}$ \\
\hline October $15-20,1985$ & 240-Daet & & \\
\hline 64) Typhoon Herming(Betty 8709) & 240-Recon & Estre!la,Naujan, & $2.08 \mathrm{M}$ \\
\hline August $8-14,1987$ & 185-Masbate & Or. Mindoro & \\
\hline 65) Typhoon Sisang(Nina8722) & 240-Legaspi City & Tiwi, Albay & $6.88 \mathrm{M}$ \\
\hline \multirow[t]{5}{*}{ November 23-27, 1987} & & Tabaco & $2.6 \mathrm{M}$ \\
\hline & & Bacacay & $3.4 \mathrm{M}$ \\
\hline & & Legaspi City & $3.9 \mathrm{M}$ \\
\hline & & Bacon, Sorsogon & $3.6 \mathrm{M}$ \\
\hline & & Gubat & $3.6 \mathrm{M}$ \\
\hline & & & \\
\hline & & & \\
\hline & & & \\
\hline & & & \\
\hline
\end{tabular}




\begin{tabular}{|c|c|c|c|}
\hline NAME OF T.C. AND DATES IN WHICH & OBSERVED & AFFECTED COASTAL & ACTUAL STORM \\
\hline THE SURGE IS ASSOCIATED WITH & MAX WINDS(kph) & AREAS -TOWN/PROVINCE & SURGE HEIGHT(M) \\
\hline \multicolumn{4}{|l|}{ continuation of Typhoon Sisang } \\
\hline & & Tagdon, Barcelona & $2.35 \mathrm{M}$ \\
\hline & & Buhang,San Vicente & $3.88 \mathrm{M}$ \\
\hline & & Sorsogon & $2.56 \mathrm{M}$ \\
\hline & & Bulabog & $3.0 \mathrm{M}$ \\
\hline 66) Typhoon Ruping(Mike 9025) & 205-Mactan & Catmon, Cebu & $2.23 \mathrm{M}$ \\
\hline \multirow[t]{7}{*}{ November $10-14,1990$} & & Bgy. Mataas, Catmon & $3.34 \mathrm{M}$ \\
\hline & & Sogod, Sin Leyte & $3.6 \mathrm{M}$ \\
\hline & & Macrohon & $3.6 \mathrm{M}$ \\
\hline & & Abuyog, Leyte & $2.4 \mathrm{M}$ \\
\hline & & Dulag, Leyte & $3.1 \mathrm{M}$ \\
\hline & & Balangkayan, E. Samar & $4.67 \mathrm{M}$ \\
\hline & & Hernani & $6.86 \mathrm{M}$ \\
\hline 67) Typhoon Paring & 120-over water & Paracale,Cam. Norte & $2.52 \mathrm{M}$ \\
\hline \multicolumn{4}{|l|}{ October $18-27,1992$} \\
\hline 68) Typhoon Rosing(Angela9520) & 255-Virac, Cat. & Bagasbas, Daet, Cam. Norte & $3.45 \mathrm{M}$ \\
\hline October 30-November 04. 1995 & 250-Daet & Yakal, Paracale & $4.93 \mathrm{M}$ \\
\hline 69) Tropical Storm Gading & 110-Dagupan & Dagupan City & $1.31 \mathrm{M}$ \\
\hline \multirow[t]{2}{*}{ September $17-21,1998$} & & Bonoan. Pangasinan & $1.52 \mathrm{M}$ \\
\hline & & San Fabian, Pangasinan & $1.06 \mathrm{M}$ \\
\hline 70) Typhoon Loleng(Babs9811) & 290-Virac, Cat. & Bagasbas, Daet, Cam. Norte & $3.44 \mathrm{M}$ \\
\hline October $15-25,1998$ & & Paracale & $2.52 \mathrm{M}$ \\
\hline & & & \\
\hline & & & \\
\hline & & & \\
\hline & & & \\
\hline & & & \\
\hline & & & \\
\hline & & & \\
\hline & & & \\
\hline & & & \\
\hline & & & \\
\hline & & & \\
\hline & & & \\
\hline & & & \\
\hline & & & \\
\hline & & & \\
\hline & & & \\
\hline & & & \\
\hline & & & \\
\hline & & & \\
\hline & & & \\
\hline
\end{tabular}




\section{APPENDIX 3}

Historical storm surge occurrences in the Philippines 1897-2011 


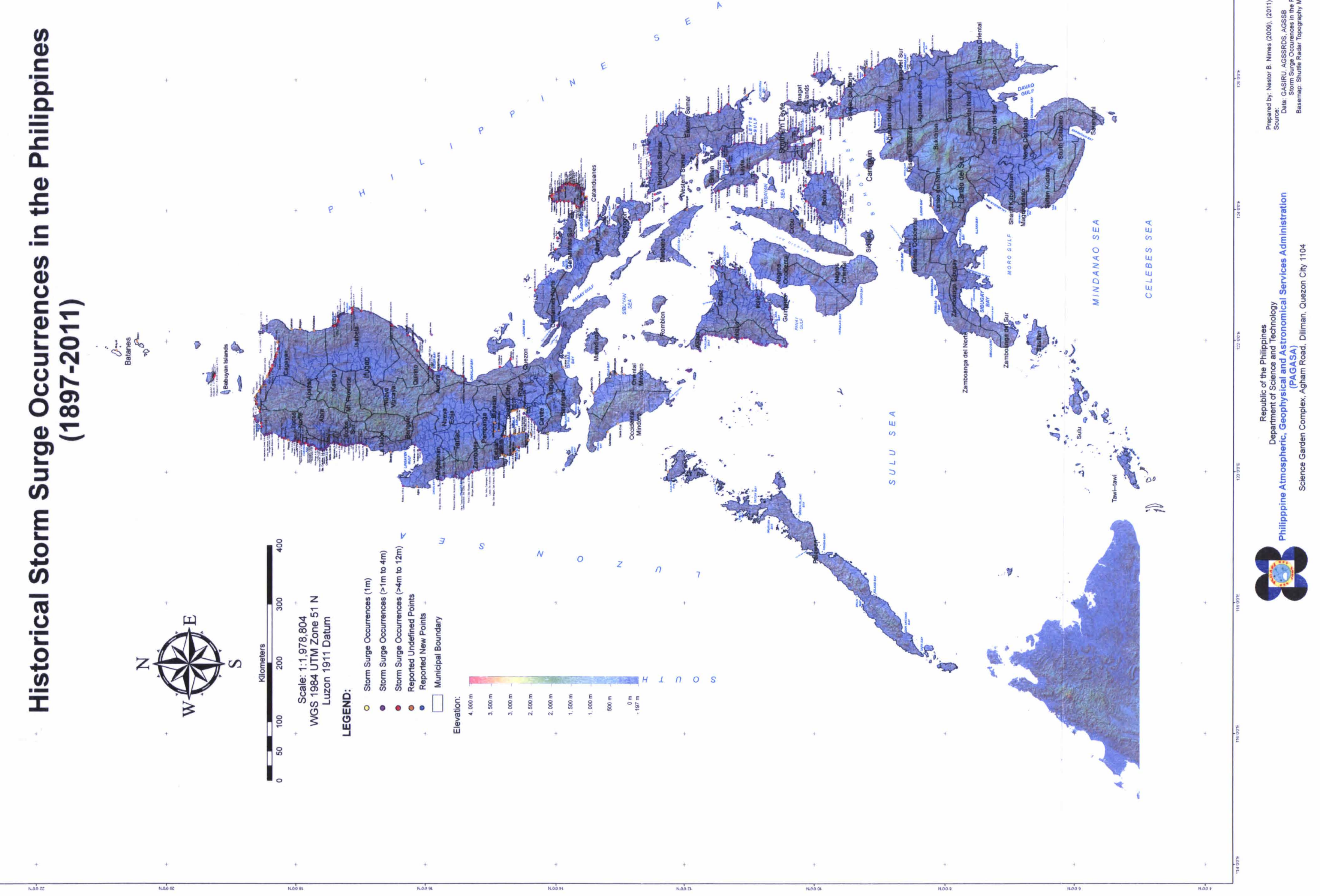

